UNIVERSIDADE DE SÃO PAULO

ESCOLA DE ARTES, CIÊNCIAS E HUMANIDADES

PROGRAMA DE PÓS-GRADUAÇÃO EM TÊXTIL E MODA

LAURA CAROLINA OLIVEIRA NOBREGA

O COURO DE PEIXE E SEUS BENEFÍCIOS NA INDÚSTRIA TÊXTIL E DE CONFECÇÃO

SÃO PAULO 
LAURA CAROLINA OLIVEIRA NOBREGA

\section{O couro de peixe e seus benefícios na indústria têxtil e de confecção}

Dissertação apresentada à Escola de Artes, Ciências e Humanidades da Universidade de São Paulo para obtenção do título de Mestre em Ciências pelo Programa de Pós-graduação em Têxtil e Moda.

Área de Concentração: Têxtil e Moda

Versão corrigida contendo as alterações solicitadas pela comissão julgadora em 14 de abril de 2015. A versão original encontra-se em acervo reservado na Biblioteca da EACHUSP e na Biblioteca Digital de Teses e Dissertações da USP (BDTD), de acordo com a Resolução CoPGr 6018, de 13 de outubro de 2011.

Orientadora: Prof ${ }^{a}$. Dr ${ }^{a}$. Maria Silvia Barros de Held

São Paulo 
Autorizo a reprodução e divulgação total ou parcial deste trabalho, por qualquer meio convencional ou eletrônico, para fins de estudo e pesquisa, desde que citada a fonte.

CATALOGAÇÃO-NA-PUBLICAÇÃO

(Universidade de São Paulo. Escola de Artes, Ciências e Humanidades. Biblioteca)

Nobrega, Laura Carolina Oliveira

O couro de peixe e seus benefícios na indústria têxtil e de confecção

/ Laura Carolina Oliveira Nobrega ; orientadora, Maria Silvia Barros de

Held. - São Paulo, 2015

$160 \mathrm{f.}:$ il.

Dissertação (Mestrado em Ciências) - Programa de Pós-

Graduação em Têxtil e Moda, Escola de Artes, Ciências e

Humanidades, Universidade de São Paulo

Versão corrigida

1. Indústria têxtil. 2. Couro - Uso. 3. Peixes. 4.

Sustentabilidade. I. Held, Maria Silvia Barros de, orient. II. Título.

CDD 22.ed. -677 
Dissertação de autoria de Laura Carolina Oliveira Nobrega, sob o título "O couro de peixe e seus benefícios na indústria têxtil e de confecção", apresentada à Escola de Artes, Ciências e Humanidades da Universidade de São Paulo, para obtenção do título de Mestre em Ciências pelo Programa de Pós-graduação em Sistemas de Informação, na área de concentração Sistemas de Informação, aprovada em 14 de Abril de 2015 pela comissão julgadora constituída pelos doutores:

\author{
Prof $^{a}$. Dr ${ }^{\mathrm{a}}$. Maria Silvia Barros de Held \\ Presidente \\ EACH - Universidade de São Paulo
}

Prof $^{a}$. Dr ${ }^{\mathrm{a}}$. Ana Margarida Fernandes

Instituto Politécnico de Castelo Branco

Prof. Dr. Dib Karam Junior

EACH - Universidade de São Paulo

Prof $^{a}$. Dr ${ }^{a}$. Regina Lara Silveira Mello

Universidade Presbiteriana Mackenzie 


\section{Resumo}

NOBREGA, Laura Carolina Oliveira. O couro de peixe e seus benefícios na indústria têxtil e de confecção. 2015. 160 f. Dissertação (Mestrado em Têxtil e Moda) - Escola de Artes, Ciências e Humanidades, Universidade de São Paulo, São Paulo, 2015.

O presente estudo teve como foco principal a observação dos benefícios do couro de peixe no mercado têxtil e de confecção. Foram comparadas amostras do couro obtido da pele de peixe com o couro bovino - principalmente - e também com couros oriundos de outros animais. $\mathrm{O}$ couro de peixe apresenta resistência superior à dos outros couros, especialmente à do couro bovino, sendo, neste caso, três vezes mais resistente. É também o único couro obtido posteriormente ao abate do animal. No caso específico do peixe, após o animal ser abatido para fins alimentícios, todo o "resto da peça" é reaproveitado. A pele vira couro, e o esqueleto vira revestimento automotivo e combustível para veículos automotores. Há, portanto, diversas opções de utilização. Ademais, essa utilidade traz benefícios também para o meio ambiente, não somente em decorrência de técnicas de reaproveitamento socioambientais, mas principalmente porque evita-se a poluição de rios e mares com o descarte, sem que sejam gerados entupimentos, poluição, intoxicações e inutilização da água.

Palavras-chave: Couro. Peixe. Reaproveitamento. Sustentabilidade. Mercado. 


\begin{abstract}
NOBREGA, Laura Carolina Oliveira. Leather fish and its benefits in the textile and apparel industry. 2015. 160 p. Dissertation (Master of Textile and Fashion) - School of Arts, Sciences and Humanities, University of São Paulo, São Paulo, 2015.

The main focus of this study is the observation of the benefits brought about by fish leather, especially when it comes to the textile and apparel market. Fish leather samples were compared to bovine leather - mainly - and to other kinds of leather. Fish leather shows stronger resistance, and it proved to be much stronger than bovine leather - specifically, three times stronger. Fish leather is also the only leather to be obtained after the animal is slaughtered. In the specific case of the fish, everything that remains from the "leftovers" is used after the edible parts of the animal are set apart. Its skin becomes leather; its bones become fuel and coatings for automobiles. Therefore, there are plenty of usage options to be considered. Furthermore, such options are eco-friendly, not only because of the social and environmental reprocessing techniques involved, but also because they prevent the pollution of rivers and seas brought about by irresponsible disposal - which may cause clogged drains, pollution, poisoning, and all sorts of contamination of the water.
\end{abstract}

Keywords: Leather. Fish. Reuse. Sustainability. Market. 


\section{LISTA DE FIGURAS}

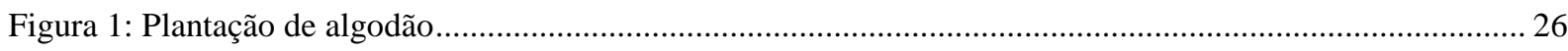

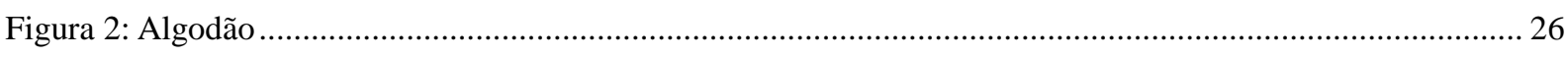

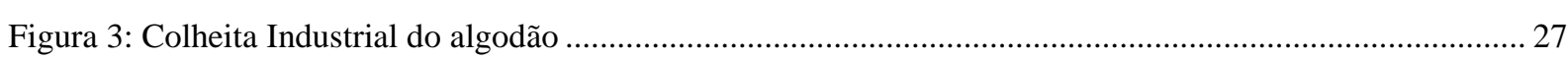

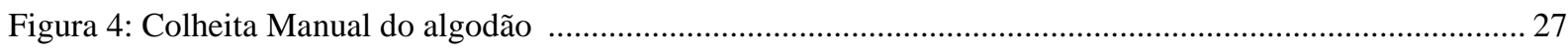

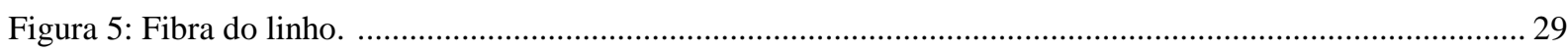

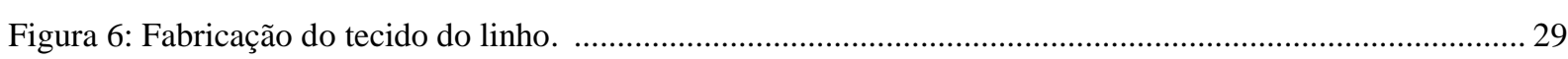

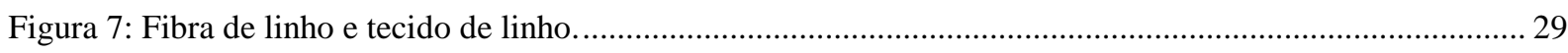

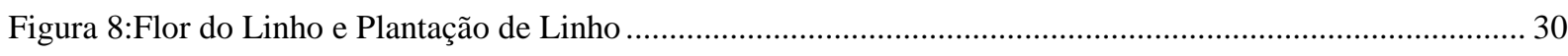

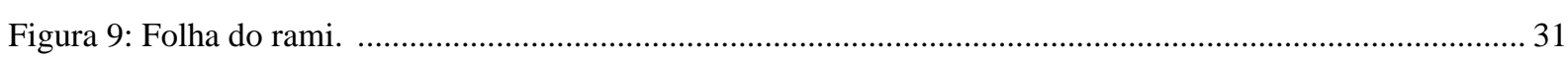

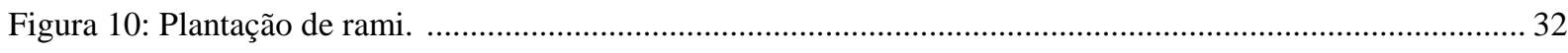

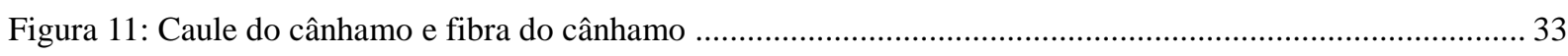

Figura 12: Semente do cânhamo e plantação de cânhamo. ……......................................................................... 33

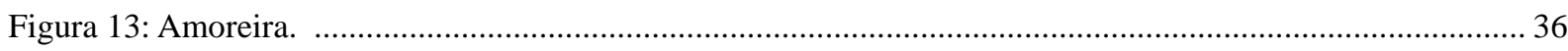

Figura 14:Casulo e casulos prontos para o banho de preparo da seda .................................................................. 36

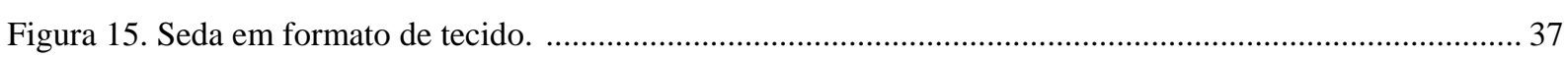

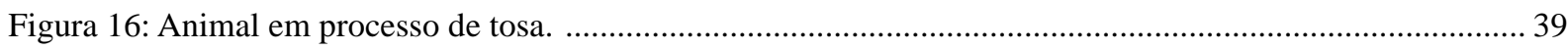

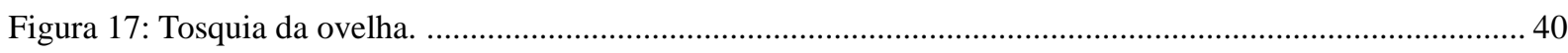

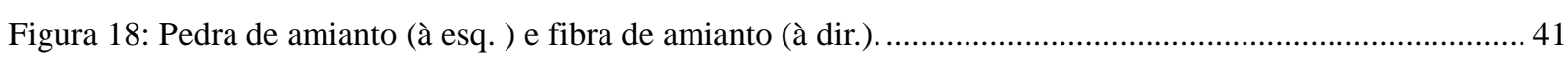

Figura 19: Fibra de amianto (à esq.) e macacão confeccionado com fibra de amianto (à dir.)................................ 41

Figura 20: Fibra de rayon vista em microscópio (à dir.) e filamento de rayon (à esq.). ....................................... 42

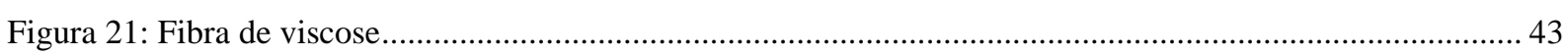

Figura 22: Tecido de viscose liso (à dir.) e tecido de viscose estampado (à esq.). ................................................ 44

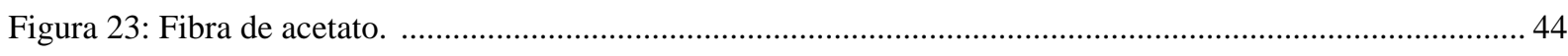

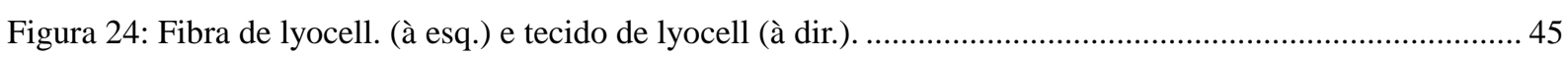

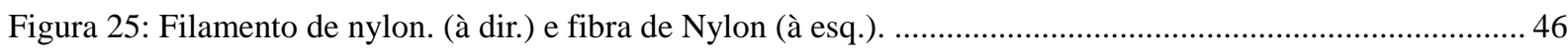

Figura 26: Fibra de poliéster.. (à dir.) e filamento de poliéster. (à esq.). ............................................................ 46

Figura 27: Fibra de acrílico (à esq.) e manta de acrílico (acrilon) (à dir.). .............................................................. 47

Figura 28: Malha de aramida. (à dir.) e manta confeccionada com aramida. (à esq.)............................................ 47

Figura 29: Fibra de polietileno triturada. (à dir.) e fibra de polietileno tubular. (à esq.) ........................................ 48

Figura 30: Espuma de poliuretano (à esq.) e travesseiro confeccionado com poliuretano (à dir.).......................... 49

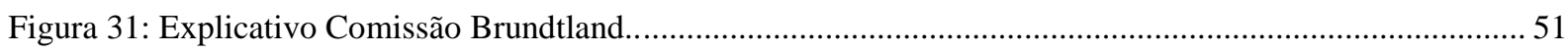

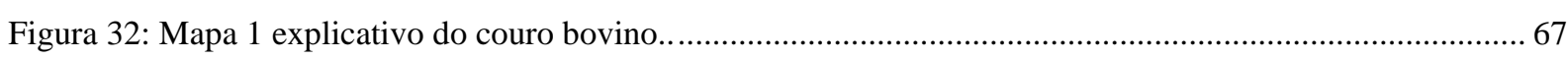

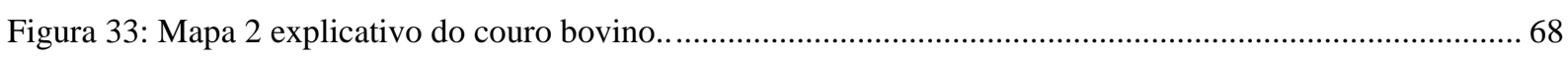

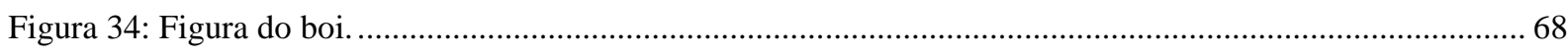

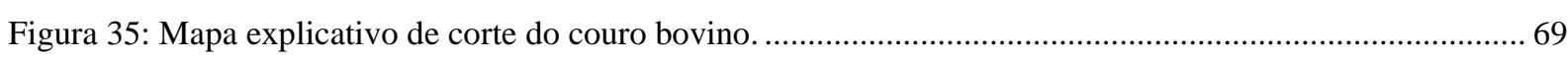

Figura 36: Mapa explicativo de corte do couro bovino. Peça inteira e peça cortada ao meio. ................................ 69

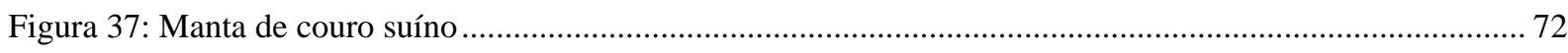

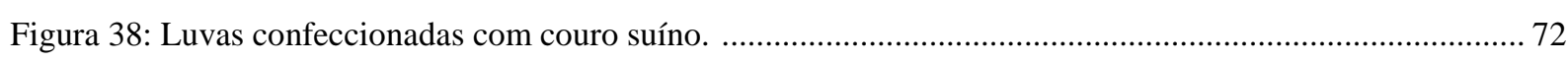




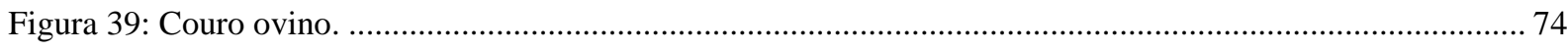

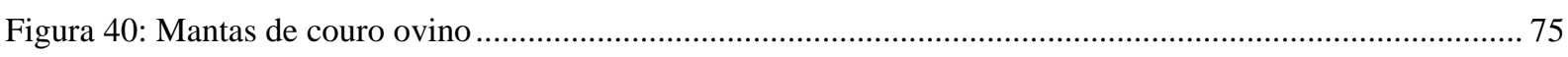

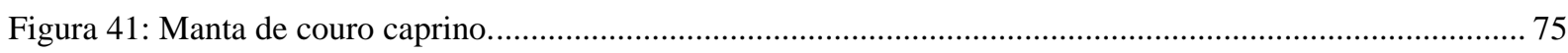

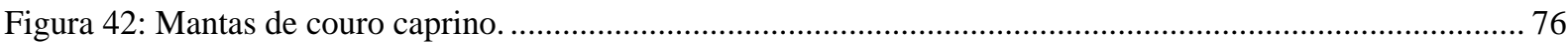

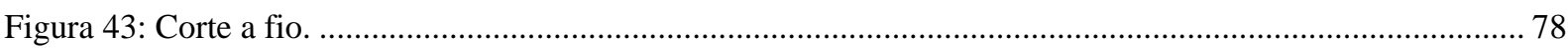

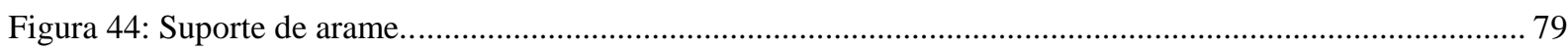

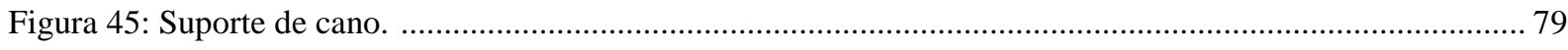

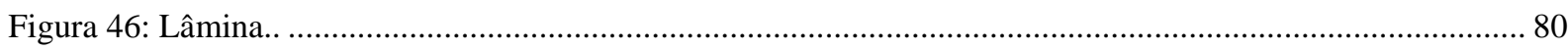

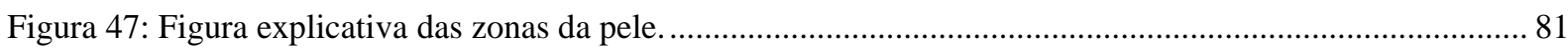

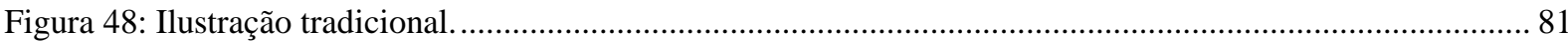

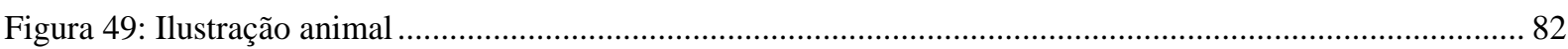

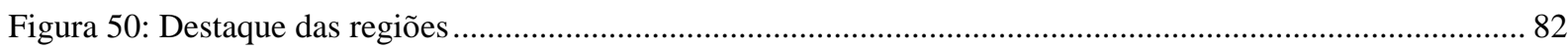

Figura 51: Sentido da elasticidade das fibras no couro inteiro e no couro dividido ao meio.............................82

Figura 52: Fluxograma esquemático da fabricação de couros - operações de ribeira, curtimento e acabamento

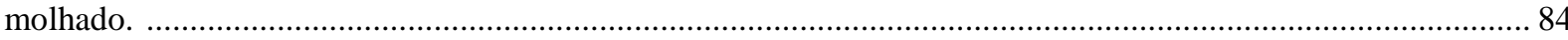

Figura 53: Fluxograma esquemático da fabricação de couros - operações de acabamento. . ............................84

Figura 54: Fulão de remolho (à esq.), fulão de curtimento (centro) e descarnadeira manual (à dir.) ...................87

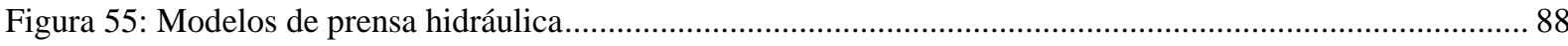

Figura 56: Calçados produzidos com couro de peixe. .......................................................................... 116

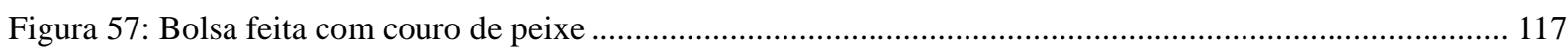

Figura 58: Pirarucu (à esq.), salmão (centro) e pescado (à dir.) .............................................................. 118

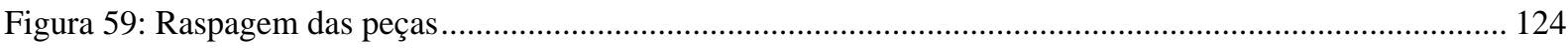

Figura 60: Equipamento utilizado no processo de curtimento................................................................. 124

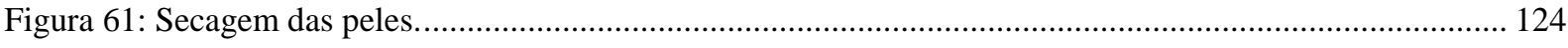

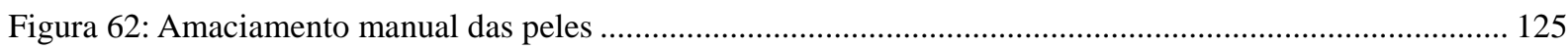

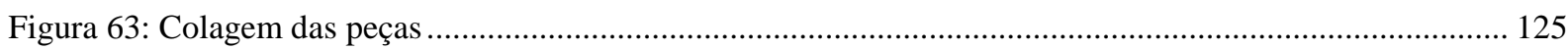

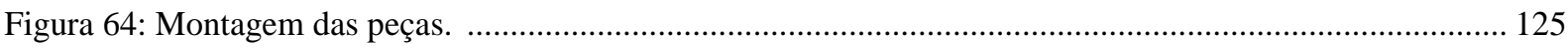

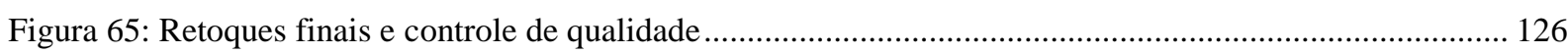

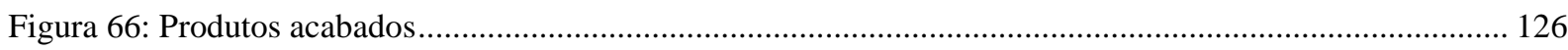

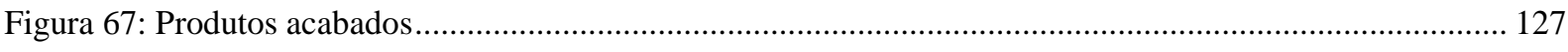

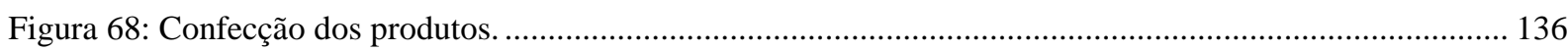

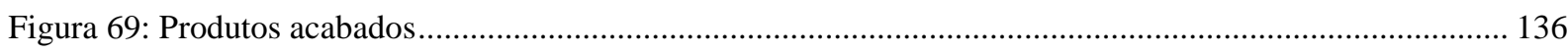

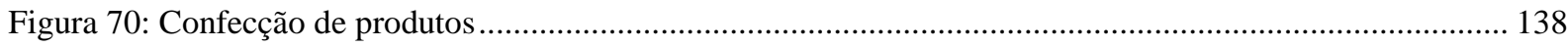

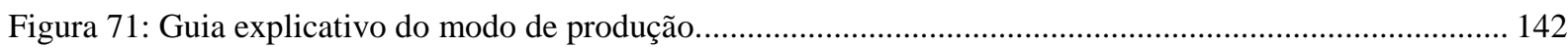

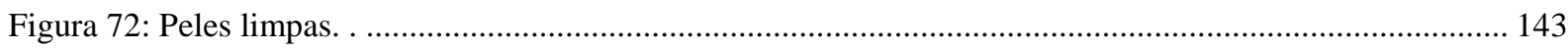

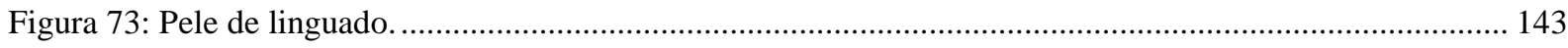

Figura 74: Linguado. Peça de cor escura (dorso do animal) e peça de cor clara (barriga do animal) ................ 144

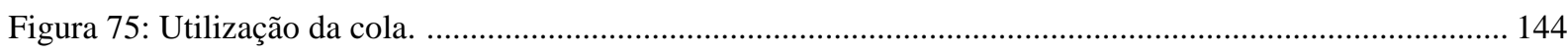

Figura 76: Pulverização da mistura de sais minerais.......................................................................... 145

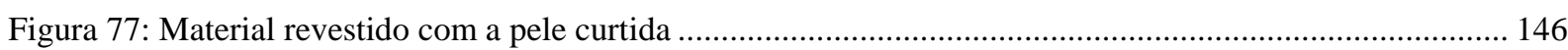


Figura 78: Corante utilizado na indústria cosmética, de aspecto pastoso, que quando utilizado como tingimento apresenta coloração azul-cintilante (à esq.); corante utilizado na indústria cosmética, encontrado na forma de pó, e que apresenta a coloração amarela (centro); corante utilizado na indústria cosmética, em formato de calda, que quando utilizado apresenta coloração de aspecto "caramelo" (à dir.).

Figura 79: Beterraba, legume que apresenta forte coloração e que, quando cozido, libera corante natural. Sua cor apresenta aspecto marcante e é de fácil fixação (à esq.); café: após moído e fervido em água quente, sua borra é capaz de tingir (centro); couve verde, cujas folhas, quando cozidas, liberam coloração esverdeada que pode ser utilizada como tingimento (à dir.) 


\section{SUMÁRIO}

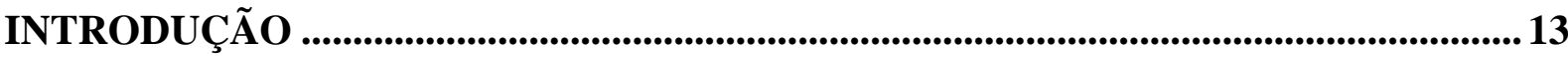

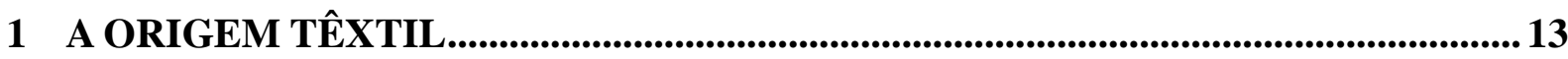

1.1 Das invenções do setor................................................................................................... 17

1.2 Matérias primas............................................................................................................. 18

1.3 Têxtil no Brasil........................................................................................................ 18

1.4 Principais Fibras têxteis ........................................................................................... 23

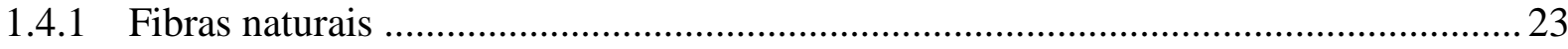

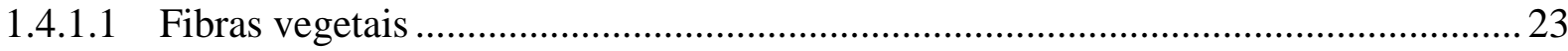

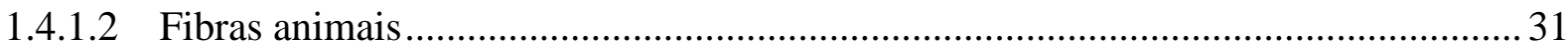

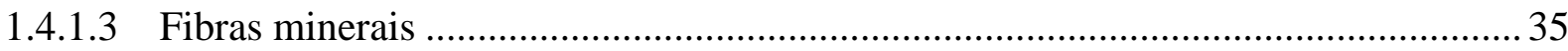

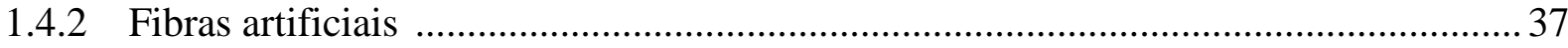

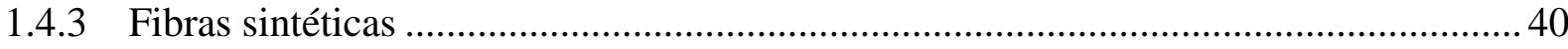

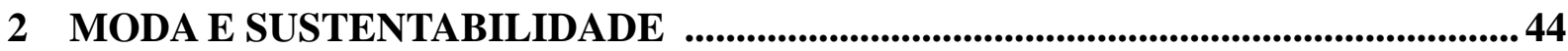

2.1 Conceito e Definição de Sustentabilidade............................................................................ 45

2.2 Definição de sustentabilidade pela Comissão de Brundtland.......................................53

2.3 ECO -92 e o modelo da sustentabilidade de três pilares ....................................................46

$2.4 O$ elo entre os três pilares da sustentabilidade ..................................................................4 47

2.5 Desenvolvimento, meio ambiente e práticas educativas ................................................. 48

2.6 Moda aliada à sustentabilidade .......................................................................................50

2.7 Consumo, capitalismo e moda .........................................................................................52

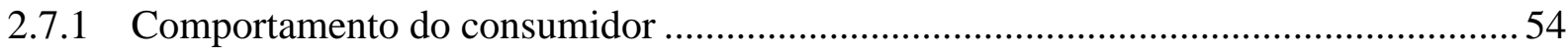

2.7.2 Moda, consumo e práticas socioambientais ………………………………………..... 55

3 COURO ……............................................................................................................ 58

3.1 Definição de couro ..................................................................................................................58

3.2 Vacum: couro de origem bovina .........................................................................................59

3.2.1 Defeitos mais comuns encontrados no couro bovino ............................................................ 61

3.3 Suíno: couro de origem suína ...............................................................................................62

3.4 Ovinos e caprinos................................................................................................................. 64

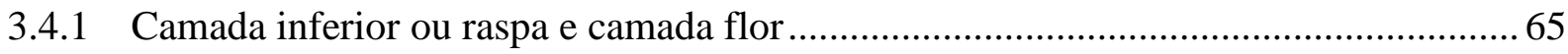

4 MOLDES, CORTE E BENEFICIAMENTO DO COURO .............................................. 67

4.1 Ordem de produção ................................................................................................................... 68

4.2 Aproveitamento racional do material .................................................................................... 68

4.3 Ferramentas ................................................................................................................69 
4.4 Zonas da pele.............................................................................................................. 70

4.5 Beneficiamento do couro

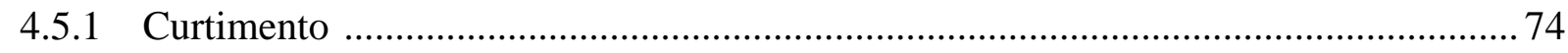

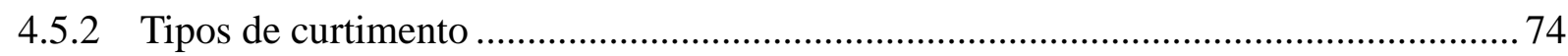

4.5.3 Classificação dos couros de acordo com o curtimento/recurtimento ............................ 75

4.6 Máquinas, equipamentos e artefatos facilitadores do processo ………………............ 75

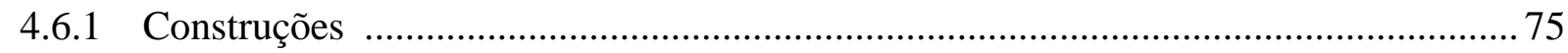

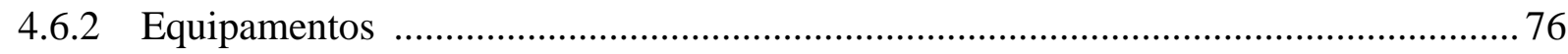

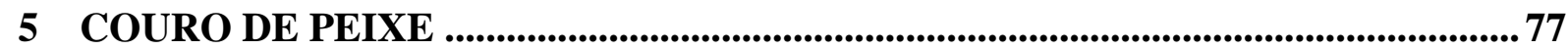

5.1 Início, desenvolvimento e continuidade ........................................................................... 77

5.2 Pesquisas realizadas no Brasil ............................................................................................ 80

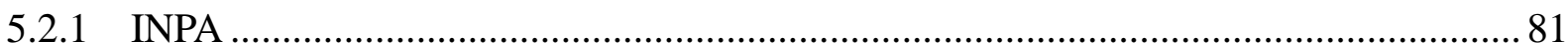

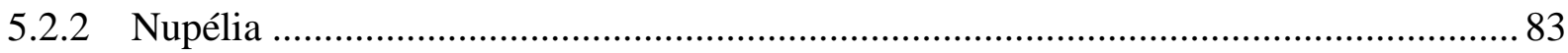

5.3 Cuidados especiais com a matéria -prima ......................................................................... 84

5.4 Beneficiamento têxtil do couro de peixe ............................................................................. 86

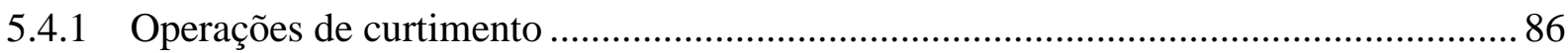

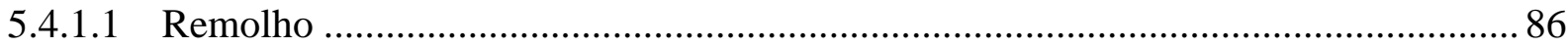

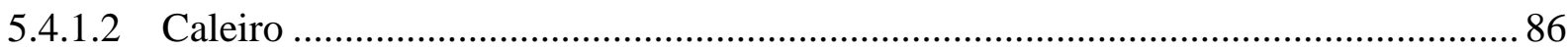

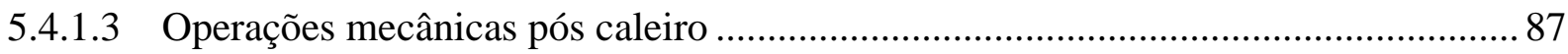

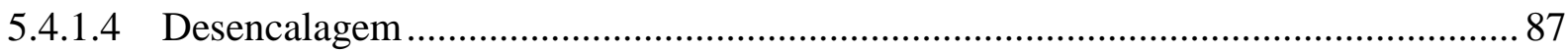

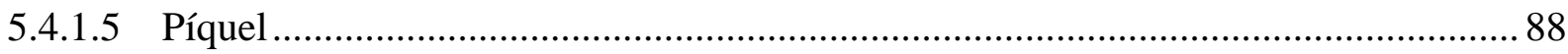

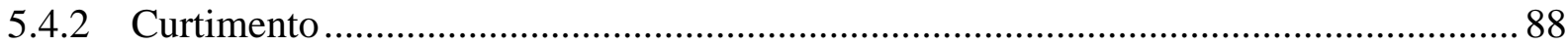

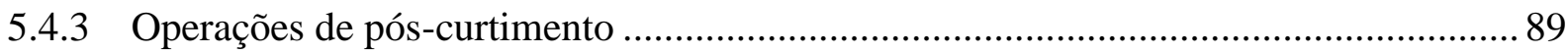

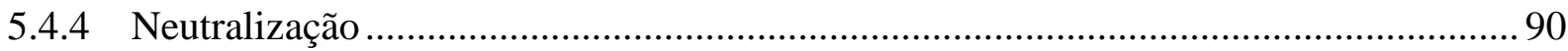

5.4.5 Tratamento de efluentes líquidos ........................................................................ 90

5.4.5.1 Descrição dos sistemas de tratamento ………………………………………...... 90

5.4.5.2 Unidade de reciclagem dos banhos residuais de curtimento ………………………... 90

5.4.5.3 Unidade de reciclagem dos banhos residuais e caleiro .............................................. 91

5.4.5.4 Tratamento físico-químico ou primário ………………………………………....... 92

5.4.5.5 Tratamento biológico ou secundário.................................................................... 94

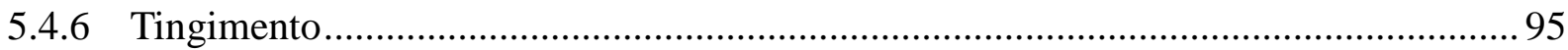

5.4.6.1 INPA desenvolve corante ecologicamente correto ……………………………….... 95

5.5 Distribuição no mercado têxtil e de confecção .................................................................97

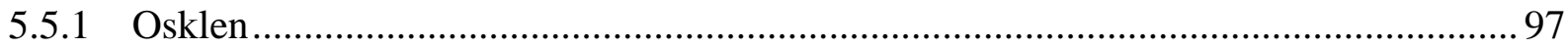

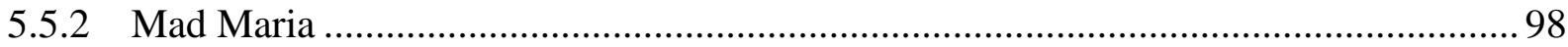




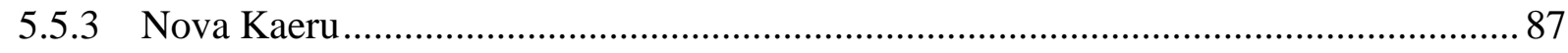

6 ONGS, INSTITUIÇÕES E COOPERATIVAS ........................................................100

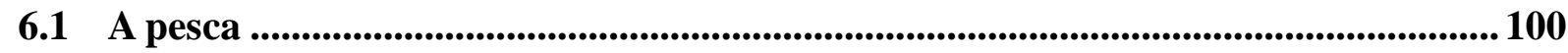

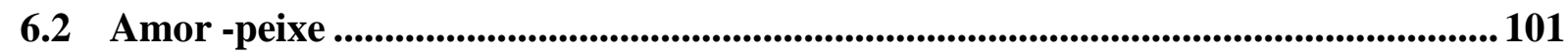

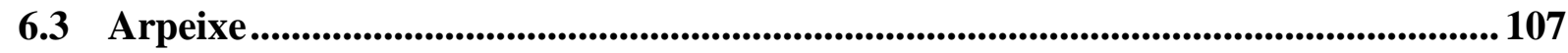

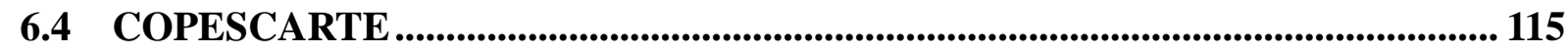

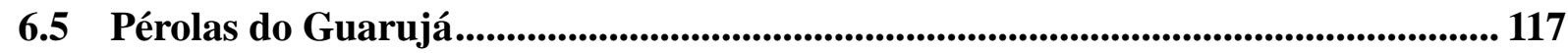

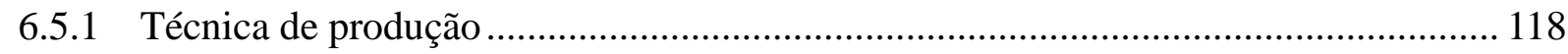

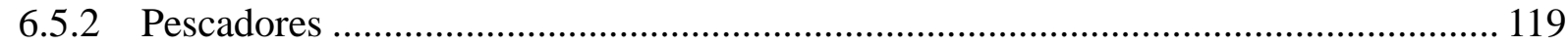

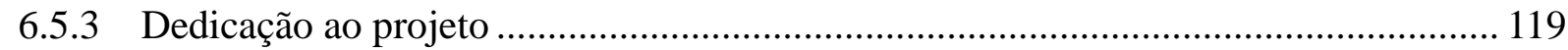

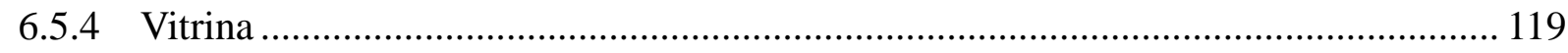

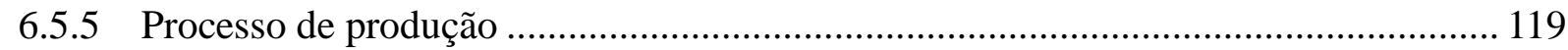

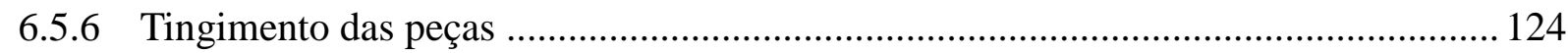

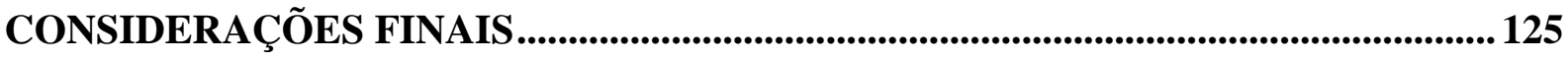

REFERÊNCIAS BIBLIOGRÁFICAS E WEBGRAFIA.................................................... 127

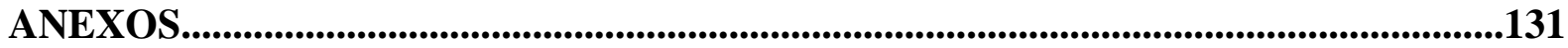




\section{INTRODUÇÃO}

Este trabalho buscou pesquisar o couro do peixe e apontar os benefícios deste couro quando inserido no mercado têxtil e de confecção.

O primeiro capítulo constitui-se de referencial teórico, e nele se examinam as facetas da indústria têxtil, sua origem e criação.

No segundo capítulo, é possível observar a importância da preservação do meio ambiente e também a procura pela obtenção de hábitos e práticas sustentáveis, principalmente no mercado têxtil e de confecção, considerado um dos maiores poluidores em função dos dejetos e de restos de matéria-prima despejados in natura, especificamente em rios e mares.

O terceiro capítulo aborda as definições de couro, enumerando-se as diferenças encontradas no couro bovino, no couro suíno e no couro obtido a partir de ovinos e caprinos.

Moldes, corte e beneficiamento do couro são temas abordados no quarto capítulo. Explanam-se os processos de produção, o aproveitamento, as ferramentas, as zonas da pele, o beneficiamento, as máquinas e os equipamentos utilizados nos couros.

No quinto capítulo é apresentado o couro de peixe. Os temas abordados incluem o início da prática, as pesquisas realizadas no Brasil, os cuidados com a matéria-prima, o beneficiamento têxtil do couro, a utilização do couro e sua distribuição no mercado têxtil e de confecção.

Por fim, no sexto e último capítulo, apresentam-se as principais ONGs, instituições e cooperativas que têm como base principal de produção e obtenção de renda o couro de peixe.

Como item conclusivo, são apresentadas as considerações finais do trabalho. 


\section{A ORIGEM TÊXTIL}

A indústria têxtil é considerada uma das mais antigas do mundo. Há milhares de anos, o homem construía seus abrigos com varas de madeira entrelaçadas com vime. Do mesmo modo, ele também preparava a cama em que dormia. Essa foi a modalidade mais grosseira de manufatura têxtil.

Com o passar do tempo, ele aprendeu a usar fibras mais macias, como o linho, a lã, os pelos de animais e o algodão, e isso, por sua vez, fez com que ele pudesse obter fios por processo manual.

Os dados de maior confiança levam a crer que o Egito, com suas múmias revestidas de tecido, e a Índia, com seus famosos panos para vestimentas, constituíram-se o berço da indústria têxtil. Em épocas remotas, essa atividade veio a transformar-se em uma operação doméstica tão vulgarizada que chegou a ocupar metade da população da Índia.

Neste país, escavações arqueológicas trouxeram à tona sinais de remotas plantações de algodão, e sabe-se que os primeiros tecidos, também com base no algodão, surgiram igualmente na Índia, especialmente na cidade de Dacca (atualmente, capital de Bangladesh), o maior centro produtor do país. A seda, por sua vez, tem na China a sua pátria - os chineses foram os primeiros a cultivar o bicho-da-seda e a aproveitar o casulo na fiação da seda natural. A seda é ainda um dos tecidos mais valorizados em toda parte.

Há relatos de sedas chinesas, com seus desenhos de dragões, pássaros e outros animais, que remontam à época da dinastia Han, no século I antes de Cristo. Os brocados chineses, comentados por Marco Polo, alcançaram seu apogeu no século XIV sob a dinastia Ming. Em relação ao linho, também há uma longa história, que começa no Egito e na Crimeia, há cerca de cinco mil anos.

Quando as primeiras grandes viagens começaram a ser empreendidas, redesenhando os contornos do mundo, as descobertas isoladas foram se espalhando. A seda, especialmente, fascinava o mundo. Chegava à Espanha e ganhava a Europa. Aos poucos, grandes centros produtores se firmavam em cidades italianas, francesas e inglesas. Os teares à época eram todos manuais - o primeiro tear mecanizado data de 1785 . No começo, e durante muito tempo, as fibras eram retiradas apenas das plantas e dos animais, até que um dia a necessidade de criar o que a natureza não havia criado fez surgir no mundo a fibra produzida em laboratório - a fibra química artificial (de matéria-prima natural vegetal ou animal; recuperada na natureza) ou a fibra de origem sintética, obtida a partir do petróleo, carvão 
mineral, entre outros, enfim.

A história dos tecidos ganhava, com esses novos aliados, um novo e grandioso futuro. Entre fibras naturais e químicas, na verdade, não há a menor animosidade. Várias vezes combinadas entre si nas tecelagens, elas vêm dando origem a uma infinita gama de tecidos, que exigem mais do que um formato de textura e um caimento adequado. As fibras químicas, na verdade, têm se esforçado para chegar o mais próximo possível das fibras naturais vegetais ou animais -, e os laboratórios têxteis se cercam dos mais variados processos em busca dessa naturalidade.

A roupa vestida, quando feita com fibras químicas, começa no polímero - a base da estrutura das fibras. É a maneira como as cadeias moleculares são dispostas no interior da fibra, que, entre outras coisas, confere a ela - e, portanto, também ao produto final, o tecido características como resistência, flexibilidade e absorção de umidade, por exemplo. A diferença fundamental entre uma fibra química e uma fibra natural diz respeito, entre outras coisas, ao seu tamanho: as fibras naturais são curtas, com exceção da seda, enquanto as fibras químicas ou sintéticas provêm de um filamento contínuo.

Os dois tipos de fibra são alvo do esforço de fabricantes de fios e tecidos, que objetivam conseguir produtos cada vez melhores. No caso de fibras naturais, os cuidados começam com a própria planta da qual são extraídas ou com os animais cuja cobertura será utilizada em sua produção.

O modo de colher o algodão e a região de onde se tira a lã do animal, por exemplo, são decisivos para a qualidade da fibra, do fio e do tecido. Do mesmo modo com relação às químicas, os esforços são constantes.

Um dos resultados mais primorosos conseguidos até hoje é a descoberta da microfibra, que possui peso absolutamente mínimo e características próximas às dos tecidos produzidos com fibras naturais. É na tecelagem que finalmente essa infinidade de fios vai ganhar corpo e virar tecido. Os teares podem se modernizar rapidamente, proporcionando a fabricação de tecidos cada vez mais confortáveis, de toque macio e aparência impecável, mas o milenar processo de trabalhar urdume e trama - os fios do comprimento de largura do tecido - é eternamente o mesmo. O modo como eles são ligados é que definirá a sua padronagem.

Da fibra para o tecido, há um longo caminho a ser percorrido. Antes de se tornar fio, as fibras passam por uma série de máquinas que as limpam, tornando-as homogêneas e paralelas. Essas mesmas máquinas estiram a fibra e dão torção - o processo que confere ao fio a coesão necessária. Quando o fio deixa os teares na forma de tecido, várias etapas ainda ocorrerão, 
como o beneficiamento têxtil, que prepara o tecido para o tingimento e a estamparia, e uma série de processos de acabamento capazes de alterar o toque e o aspecto, tornando-o impermeável ou aveludado.

Definição de têxtil:

Segundo Jorge de Palma, em seu livro Fibras, filamentos e fios, do ano de 2003, p. 8:

Têxtil, derivado do latim, "texere", significa tecer;

Originalmente aplicado em tecidos planos (tear);

Posteriormente tornou-se um termo geral para o universo das fibras.

Exemplos de Têxteis:

Fios, cordas, fitas, rendas, passamanarias, bordados, redes, tecidos, entre outros.

Indústrias têxteis:

Manufatoras de fibras químicas e artificiais (sintéticas), beneficiadoras de algodão, fiações, tecelagens, malharias, confecções, não tecidos, tinturarias etc.

Tipos de indústria:

Indústria têxtil, indústria química, indústria mecânica, indústria eletroeletrônica.

Utilização dos produtos derivados da indústria têxtil:

Vestuário:

Roupas em geral, linha íntima, uso esportivo, entre outros.

Doméstico: cama, mesa, banho, mobílias, cortinas, tapetes, carpetes, entre outros.

Industrial e proteção: produtos para composição de pneus, cintos de segurança, correias, mangueiras; produtos de processamento, como filtros, telas, sacos para lavagem, entre outros; outras destinações, como sapatos, luvas, toldos, barracas, lonas, paraquedas, entre outros. 
Origem e evolução:

Segundo Toffle apud Palma (2003), os indícios mais antigos da presença de objetos têxteis remontam a mais de 10 mil anos, coincidindo com a agricultura sedentária dos primeiros homens.

Os mais antigos têxteis (tecidos de lã - 9000 a.C.) foram encontrados nas civilizações lacustres da Suíça, na Mesopotâmia, na Cordilheira dos Andes e no norte da Escandinávia. Também há indícios de têxteis em grutas da Península Ibérica, além de representações em pedras e pinturas rupestres de homens e mulheres vestidos com peças têxteis facilmente identificáveis. Outros produtos, como redes e cestos feitos de plantas flexíveis como a cana e o junco, datam de 5000 a. C.

Há relatos de que o algodão é conhecido desde 3000 a.C. e de que em 1500 a.C. já era cultivado na Índia para a produção de tecido. Os chineses teceram algodão mil anos depois.

Em 2640 a.C. foi descoberta a seda na China, pela imperatriz Hsi Ling.

No antigo Egito os materiais têxteis usados eram o algodão, a seda, a lã e as fibras de linho. Já em 2500 a.C. os egípcios conheciam a arte de fiar com perfeição e teciam tafetá e sarja. Há evidências de produção de tecidos estampados na Índia durante o quarto século a.C. Foram encontrados em ruínas romanas espécies de tecidos tintos datadas do ano de 200 a.C.

\subsection{Das invenções do setor}

Segundo Souza (2011), engenheiro têxtil e autor do artigo intitulado "Tecnologia Têxtil - Origem e Evolução da Indústria”, na planilha especificada abaixo pode-se comprovar datas marcantes do período de evolução da indústria têxtil.

Ano

\section{Atividade/Ferramenta}

$1700 \quad$ Tear manual com lançadeira.

1733 Lançadeira voadora com corda - tecelagem ultrapassou a produção de fios.

1738 a 1748 Estiragem por cilindros e carda de cilindro.

1764 Spinning Jenny - aperfeiçoamento do torno de fiar com 120 fusos.

1769 Fiandeira hidráulica - fio regular. 
1775 Cardas, passadores, maçaroqueiras e filatórios.

1779 Surgem os motores a vapor - maior produção da fiação.

1789 Tear mecânico com motor a vapor - equilíbrio entre fiar e tecer.

1794 Descaroçador de serra.

$1806 \quad$ Tear Jacquard.

$1828 \quad$ Filatórios de anéis.

\subsection{Matérias-primas}

Ano

10000 a.C. Lã

5000 a.C. Plantas Fibrosas

3000 a.C. $\quad$ Algodão

2600 a.C. $\quad$ Seda

1889 d. C. Surge a fibra artificial de viscose, chamada de "seda artificial".

1941 d.C. $\quad$ Surge a fibra sintética (JR Winfield); poliéster (PET): terylene ou dracon.

1955 d.C. Surge a produção em larga escala do poliéster.

Atualmente Surgimento de novos materiais têxteis.

\subsection{Têxtil no Brasil}

Em relatos dos navegadores enviados ao Brasil na época do descobrimento, constatouse que a atividade têxtil, ainda que de forma rudimentar, já era exercida pelos habitantes e que o algodão era a fibra mais utilizada nos processos de fiação e tecelagem.

No primeiro documento escrito enviado do Brasil a Portugal - a Carta de Pero Vaz de Caminha -, há referência a "uma mulher moça com um menino no colo, atado com um pano não sei de quê aos peitos". O atento escrivão assinalou, mais adiante, que "as casas tinham 
dentro muitos esteios e, de esteio a esteio, uma rede atada pelos cabos em cada esteio". Embora não tenha declarado expressamente tratar-se de redes de algodão, pode-se chegar a essa conclusão pela consulta a outro documento, conhecido como Relação do piloto Anônimo, no qual um tripulante da armada de Cabral, ao descrever os costumes dos silvícolas, assinalou:

\begin{abstract}
As suas casas são de madeira, cobertas de folha e ramos de árvore, com muitas colunas de pau pelo meio e entre estas e a parede pregam redes de algodão, nas quais podem estar um homem e, diante de cada rede fazem um fogo, de modo que numa só casa pode haver quarenta ou cinquenta leitos a modo de teares.
\end{abstract}

(PALMA, 2003, p.11)

Com a introdução dos escravos africanos no Brasil, iniciada ainda na primeira metade do século XVI, começou a desenvolver-se a cultura do algodoeiro, visando, entre outras razões de suma importância, a fabricação de panos grossos, destinados a cobrir-lhes a nudez. A fiação e a tecelagem eram feitas com auxílio de instrumentos rústicos, como as rocas e os primitivos fusos, e o trabalho se executava em ambiente doméstico, do qual se ocupavam tanto os senhores como os escravos.

Entre 1580 e 1640, Portugal foi parte da União Ibérica, o que fez com que suas colônias ultramarinas fossem hostilizadas pelos inimigos do reino da Espanha. As sucessivas invasões holandesas (de 1624 a aproximadamente 1650), em busca de açúcar, desorganizaram por completo a economia da colônia.

Com a expulsão holandesa em torno de 1650, iniciou-se de imediato o trabalho de recuperação. Os engenhos voltaram a produzir como antes e as lavouras foram objeto de proteção especial, no sentido de se ativar a produção agrícola. No Maranhão, sobretudo, os algodoeiros começaram a produzir de tal forma que em pouco tempo o produto passou a ocupar o primeiro lugar nas exportações. Data dessa época a utilização do algodão como moeda de troca, atribuindo-se valores aos novelos e aos tecidos já prontos, que eram medidos por varas.

No século XVII, no ciclo da caça aos índios pelos bandeirantes com o intuito de arrebanhar mão de obra escrava, o algodão passou a ser utilizado também na confecção de coletes acolchoados com grossos chumaços, destinados a evitar a penetração das mortíferas setas arremessadas pelos silvícolas.

O descobrimento do ouro e dos diamantes em Minas Gerais, em um primeiro momento, serviu como entrave ao desenvolvimento agrícola do país, que começou a sofrer 
restrições, pois ocupava mão de obra necessária à extração mineral. A concentração humana advinda dessa atividade mineradora fez com que o algodão voltasse a ter um papel de destaque. Havia necessidade urgente de grande quantidade de pano para vestir a população, que aumentava consideravelmente de ano para ano. Em Minas Gerais, os teares manuais multiplicavam-se e diversificava-se a produção, que passou a englobar tecidos de várias fibras, além do algodão. Diante de uma promissora atividade que se desenvolvia na colônia, Portugal não ficou inerte. Com uma mentalidade eminentemente mercantilista, resolveu investir na nova atividade. Em carta remetida a 21 de março de 1750 pelo ministro Diogo de Mendonça Côrte Real ao Marquês de Távora, vice-rei da Índia, encontra-se o seguinte conteúdo: "Considerando as singulares disposições, que a natureza uniu na Capitania do Pará para poder nela estabelecer manufaturas de chitas e outras obras de algodão, o grande benefício que deste estabelecimento pode resultar no Estado do Maranhão e, ao comércio do Reino, houve S.M. por bem determinar que se faça toda a diligência por ajuntar casais de tecelões e pintores daquelas partes da península da Índia, onde se fabricam as melhores chitas e lenços e que estas famílias se transportem para a Bahia, onde se antecipa ordem, que dali se façam passar ao Pará”. As providências tomadas por Portugal na mesma década não se restringiram apenas a essa convocação de tecelões. Duas companhias de comércio, criadas em 1753 e 1758, respectivamente, deveriam cooperar com o transporte do algodão brasileiro. As exportações brasileiras começaram a tomar proporções tais que Portugal passou a se constituir também em um dos principais fornecedores da matéria-prima para as fábricas inglesas.

Outro fator de origem externa veio incrementar ainda mais a nossa produção: a crise entre a Inglaterra e suas colônias na América, motivada por desejos de independência, na década de 1770. Privada do algodão americano que abastecia suas indústrias, a Inglaterra teve que buscar alternativas de fornecimento. Beneficiou-se disso o governo português, pois, conforme observou um dos autores do livro The cotton plant, editado em 1922, "for few years all the increased supply came from Brazil", ou seja, durante alguns anos, todo o acréscimo no fornecimento do algodão veio do Brasil. A produção brasileira aumentava a cada dia, e começavam a ameaçar a coroa. Tecidos saídos das tecelagens instaladas na Bahia, Pernambuco, Maranhão, Paraíba e Minas Gerais não tinham características unicamente rudimentares, e começavam a concorrer com a produção das tecelagens de Portugal, até então nosso principal fornecedor. Desses centros, Minas era o que mais preocupava os portugueses, porque os lucros conseguidos com a extração do ouro haviam formado um mercado consumidor significativo para a época. Os teares começaram a se multiplicar, produzindo tecidos cada vez mais finos, e a coroa portuguesa passou a temer a força que poderia advir dessa produção - quem sabe, alguns sonhos de independência. Relatórios das autoridades 
locais falavam de donos de teares que vestiam a família e os escravos com o tecido que fabricavam de linho, algodão e lã. Há até anotações sobre uma pequena indústria em Registro Velho, perto de Barbacena, fundada em 1768, cujos tecidos faziam sucesso em todo o país.

Desde praticamente o início do governo de Pombal (período pombalino), iniciado em 1750, as autoridades portuguesas passaram a se preocupar com a multiplicação do uso de teares no Brasil, especialmente na Capitania de Minas, como foi colocado anteriormente. Culpava-se, como sempre, a agricultura de prejudicar o trabalho da extração do ouro nas lavras. Desde 1763 deixara de ser alcançada a quota de cem arrobas anuais para pagamento do quinto $^{1}$, que fora estabelecido como limite mínimo, por acordo celebrado entre câmaras municipais e a junta Real Fazenda da Capitania de Minas Gerais, sediada em Vila Rica. Além do problema que Portugal enfrentava com relação a Minas Gerais, havia outro que necessitava de providências urgentes e enérgicas. Navios ingleses, protegidos pela complacência dos governadores e pela fiscalização defeituosa ou corrupta dos responsáveis nos portos e alfândegas, praticavam o mais deslavado contrabando, suprindo as casas comerciais, principalmente do Rio de Janeiro e da Bahia, de produtos industrializados de toda natureza, sobretudo os tecidos de algodão fabricados na Grã-Bretanha.

Decidido a pôr um fim a essa situação, o governo português resolveu intervir, tomando medidas no sentido de impedir qualquer tentativa de implantação da indústria de tecidos em nosso país. Além disso, ordenou severa vigilância sobre a carta trazida pelos navios ingleses. Um alvará firmado em 5 de janeiro de 1785 pela rainha D. Maria I proibia a produção de têxteis no país, e estancava com um só golpe uma das atividades mais desenvolvidas na época, a das tecelagens. Com a determinação de D. Maria I, todos os teares se imobilizaram, uma vez que sua ordem foi cumprida com extremo rigor. Assim que foi tornado público, o alvará desencadeou uma verdadeira caçada à produção têxtil, do norte ao sul do país.

O provedor do vice-rei em pessoa se apresentava muitas vezes às portas dos locais onde teares trabalhavam, geralmente galpões anexos às casas dos seus donos. Apreendiam os equipamentos, que eram recolhidos aos armazéns da fazenda real e mais tarde enviados a Portugal, depois de seus donos assinarem um documento no qual se sujeitavam ao que a rainha determinasse sobre o assunto.

Com a chegada de D. João VI ao Brasil em 1808, em decorrência das conquistas napoleônicas, o alvará de 1785 foi extinto, e a indústria têxtil brasileira conheceu uma nova fase. Com a abertura dos portos às nações amigas, as exportações foram reabertas e a

- $\quad{ }^{1}$ Imposto cobrado pela coroa portuguesa sobre o ouro encontrado em suas colônias. 
produção de têxteis nacionais, incentivada. Lamentavelmente, dois anos mais tarde, o Brasil se viu invadido por têxteis ingleses. A coroa assinara um tratado com a Inglaterra que concedia privilégios sem precedentes a esse país, como a imposição de tarifas alfandegárias em um patamar bem abaixo em relação às exigidas dos outros países. Essa época foi uma das mais nefastas para a nascente indústria têxtil nacional. Até o final do século XIX, há registros da existência de 44 tecelagens, distribuídas por todo o país.

Foi entre 1900 e 1915 que o setor realmente se desenvolveu - o número de fábricas cresceu mais de $100 \%$ nesse período, assim como o número de seus funcionários e sua produção. Havia mais de 200 fábricas e quase 100 mil funcionários, que supriam plenamente o mercado interno.

Com a eclosão da Primeira Guerra Mundial, fábricas se instalaram por todo o país, principalmente em Minas Gerais, Rio de Janeiro e São Paulo. O crescimento continuou até a década de 30, quando a depressão deflagrada pela queda da bolsa de valores de Nova York, em 1929, estagnou a produção. Novas leis tornaram proibitivas as importações, tanto pelas altas taxas impostas quanto pelos entraves burocráticos, o que acarretou em dificuldades na modernização do maquinário brasileiro, cujos reflexos seriam sentidos mais tarde.

Após a eclosão da Segunda Guerra Mundial, o Brasil manteve-se como razoável exportador, tendo em vista que os países diretamente envolvidos no conflito tiveram seus parques industriais seriamente abalados. Tal situação durou pouco, pois aquelas nações rapidamente se recuperaram, ao contrário do Brasil, que, em virtude de diversos fatores como má qualidade da matéria-prima, administração deficiente, carência de mão de obra qualificada, métodos e processos antiquados de produção (equipamentos fabricados, então, há vinte anos) -, permaneceu estagnado e dependente do exterior. As máquinas usadas na obsoleta e incipiente indústria têxtil brasileira, além de antiquadas, eram copiadas de equipamentos importados, por conta da falta de tradição industrial.

Entre a década de 50 e o final da de 60, graças aos estímulos governamentais criados com o objetivo de se incrementar a industrialização, o Brasil passou à fase de compra de tecnologia e de fabricação de equipamentos "sob licença".

Com o regime militar imposto no Brasil, a partir de 1964, as importações foram proibidas e o país novamente distanciou-se das inovações tecnológicas que eram introduzidas em outros países.

Após a abertura econômica, ocorrida na segunda metade da década de 80 e início dos anos 90 , o país retomou o seu crescimento. 
Segue abaixo um trecho da carta:

Carta da Rainha I de Portugal

$\mathrm{Eu}$, a Rainha, faço saber aos que este Alvará virem, que sendo-me presente o grande número de fábricas e manufaturas, que de alguns anos a esta parte se têm difundido em diferentes capitanias do Brasil, com grave prejuízo da cultura, da lavoura e da exploração das terras minerais daquele vasto continente, porque havendo nele uma grande conhecida falta de população, é evidente que, quanto mais se multiplicar o número de fabricantes, mais diminuirá o de cultivadores; e menos braços haverá que possam se empregar nos descobrimentos e rompimento de uma grande parte daqueles extensos domínios, que ainda se acha inculta e desconhecida

(...) hei por bem ordenar que todas as fábricas, manufaturas ou teares de galões, de tecidos ou de bordados de ouro e prata, de veludos, brilhantes, cetins, tafetás ou qualquer outra qualidade de seda; de belbutes, chitas, bombazinas, fustões ou de outra qualidade de fazenda de algodão ou linho branco ou de cores; e de panos, baetas, saetas, ou de outra qualquer modalidade de tecidos de lã (...) sejam extintas e abolidas em qualquer parte onde se acharem nos meus domínios do Brasil.

Maria I, Rainha de Portugal

(PALMA, 2003, p.16)

\subsection{Principais fibras têxteis}

\subsubsection{Fibras naturais}

As fibras conhecidas como naturais têm como base as matérias-primas de origem vegetal, animal e mineral.

\subsubsection{Fibras vegetais}

São exemplos de fibras naturais vegetais o algodão, o linho, o rami e o cânhamo.

Segundo Palma (2003), das flores do algodoeiro desenvolvem-se cápsulas que se abrem quando maduras. Dentro destas ficam as fibras fixadas nas sementes. Depois da secagem, as fibras são retiradas e, em seguida, prensadas em forma de fardos. As fibras curtas que ficam nas sementes são retiradas em outros processos e recebem o nome de "linter", que é utilizado como celulose para a fabricação de fibras artificiais.

Ainda de acordo com Palma (2003), a fibra do algodão é quase inteiramente composta de celulose - de $88 \%$ a $96 \%$ de sua composição. Além de celulose, ela contém pequenas porções de proteína, pectina, cera, cinzas, ácidos orgânicos e pigmentos. Essa fibra - de propriedades têxteis de finura, resistência e flexibilidade - foi uma das primeiras fibras utilizadas pelo homem, e atualmente há mais de 70 países que se dedicam à produção do 
algodão.

Os primeiros textos que falam da utilização do algodão datam de 1500 a.C. Os tecidos mais antigos feitos de algodão remontam ao Paquistão, mais ou menos no ano 3000 a.C., e ao norte do Peru, por volta de 2400 a.C.

Heródoto descreve, em sua História do mundo, árvores da Índia que forneciam uma lã superior àquela fornecida pelo carneiro. A língua alemã designava o algodão com o termo "baumwolle", que quer dizer lã da árvore.

Dessa forma pode-se concluir que o algodão, ao lado do linho, da lã e da seda, foi uma das primeiras fibras têxteis utilizadas na confecção de tecidos.

No Brasil, segundo Palma (2003), é a fibra mais cultivada, e pode ser classificada em duas categorias:

I) Meridional - Nos estados de São Paulo, Paraná, Minas Gerais e Goiás. São fibras mais curtas, menos resistentes e mais grossas que as produzidas na área setentrional. Sua principal aplicação são os fios para tecidos e malhas.

II) Setentrional - Nos estados de Alagoas, Sergipe, Pernambuco, Paraíba, Maranhão, Piauí, Ceará e Rio Grande do Norte. A variedade mais conhecida é o seridó, que consiste em fibras mais resistentes, finas e brilhantes. Aplica-se em fios de alta qualidade, destinados à fabricação de tecidos, malhas e, principalmente, linhas de costura.

Figura 1: Plantação de algodão.

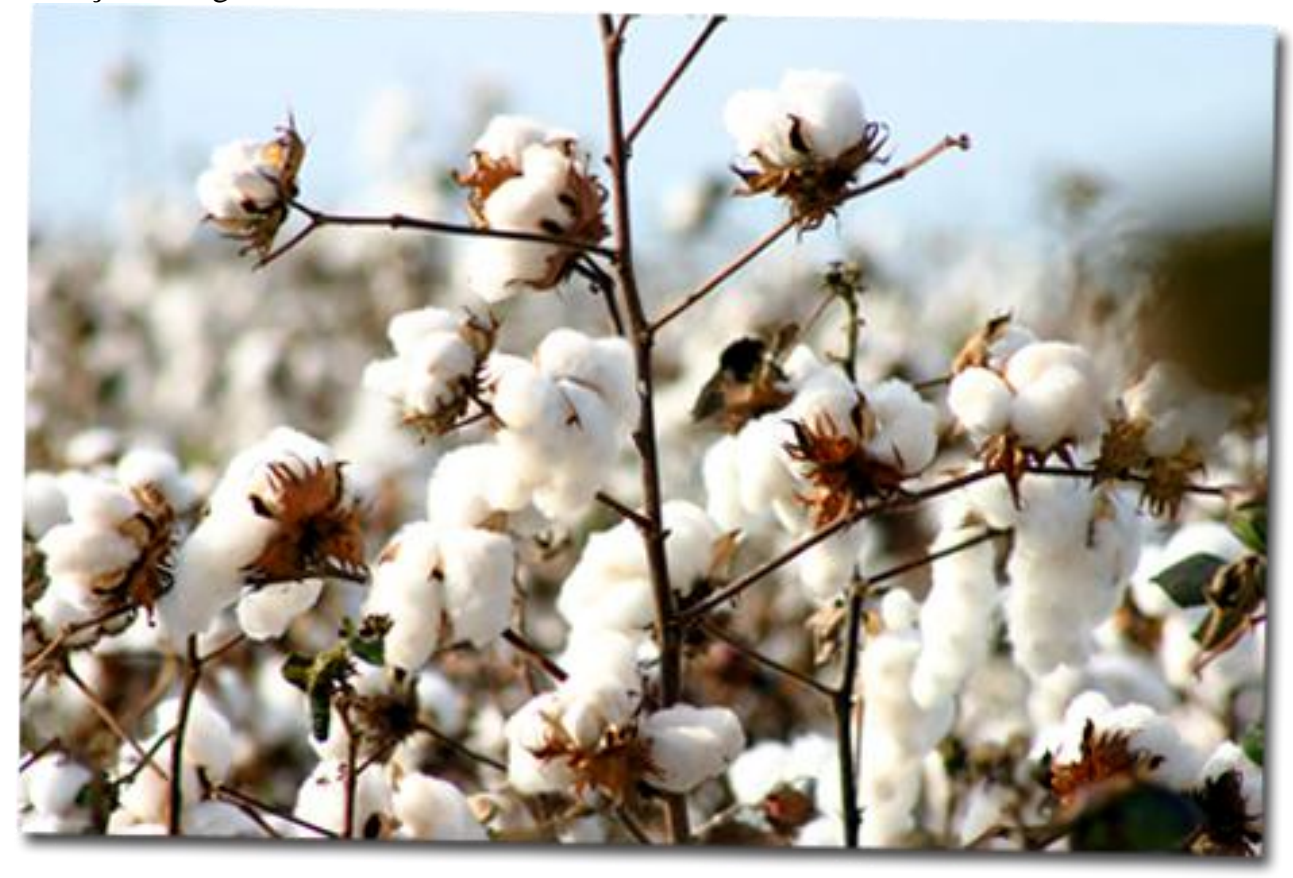


Fonte: <http://www.correiodoestado.com.br/noticias/grande-exportador-de-algodao-brasil-pode-perdermercado_197002>, acesso em 15 nov. 2013, às 11 h54.

Figura 2: Algodão.

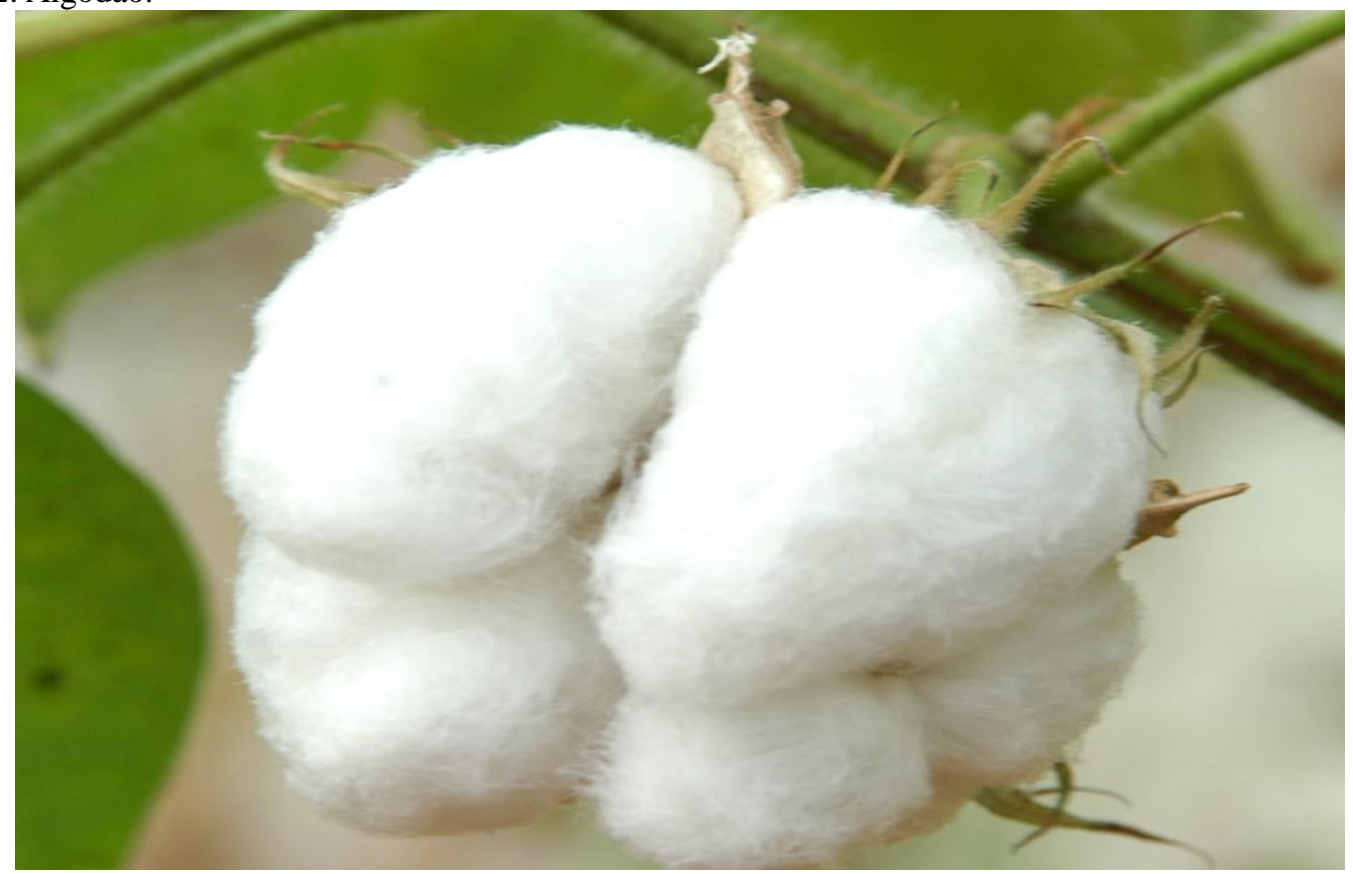

Fonte: <http://detalhesdacriacao.wordpress.com/2010/09/27/de-onde-vem-o-algodao/>, acesso em 15 nov. 2013 , às $12 \mathrm{~h} 10$.

Figura 3: Colheita industrial do algodão.

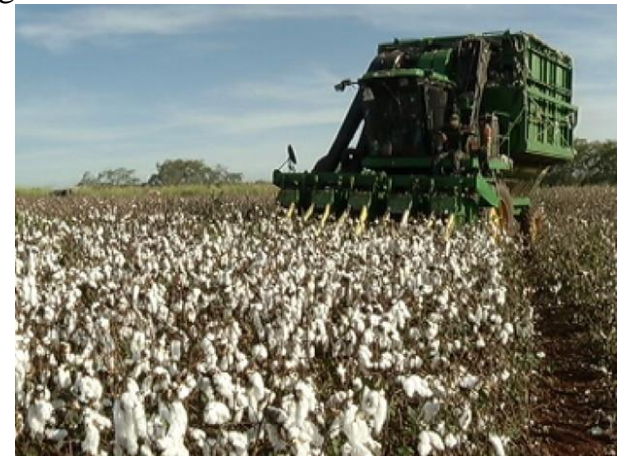

Fonte: <http://mtagronews.blogspot.com.br/2013_03_01_archive.html>, acesso em 18 nov. 2013, às 17 h50.

Figura 4: Colheita manual do algodão.

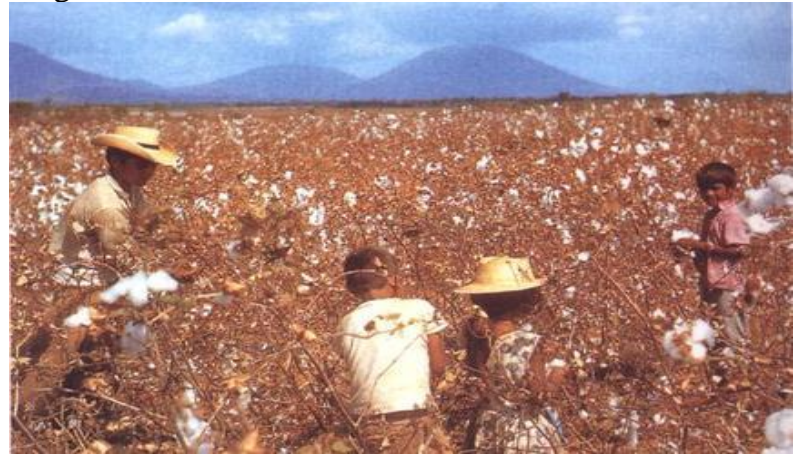


Fonte: 〈http://www.tecelagemanual.com.br/algodao.htm>, acesso em 18 nov. 2013, às $15 \mathrm{~h} 17$.

De acordo com Palma (2003), o linho é uma fibra de caule, e sua maior parte é formada de celulose. Em seu estado natural, apresenta $70 \%$ de celulose, com água, gordura, cera, cinzas e material intercelular compondo o restante.

O Egito foi a civilização que mais utilizou o linho em sua história. Além do aspecto religioso, o linho era utilizado como vela nas embarcações dos fenícios e foi até motivo de reflexão de filósofos como Virgílio e Heródoto; serviu também como identificador de classes sociais, pois só os nobres, religiosos e faraós podiam se utilizar do linho em suas vestes, ficando para as outras classes menos privilegiadas a utilização de fibras menos nobres.

O linho é uma das mais antigas e valorizadas fibras têxteis. As primeiras notícias de sua utilização datam de mais de 5 mil anos, nos processos de mumificação e embalsamento de reis e faraós. Mais de mil metros de tecido eram utilizados em um processo de mumificação.

Não está incluída aí a quantidade de linho utilizada para embrulhar o tesouro que ia junto para o sarcófago. Gregos e romanos tiveram o primeiro contato com o linho graças aos navegantes fenícios, que usavam o tecido nas suas embarcações. Não tardou para os romanos trocarem a aspereza das suas vestimentas pesadas de lã pela sensação de conforto das roupas de linho.

Para os hebreus, segundo o mesmo autor, era inadmissível a mistura do linho a outras fibras - a preocupação era a de não comprometer a qualidade do tecido. A industrialização do linho é mais recente. As primeiras fiações industriais surgiram no começo do século XVII, e o seu grande incentivador foi Napoleão Bonaparte. Ele não se conformava com a concorrência do algodão inglês.

As experiências com a industrialização da fibra, entretanto, apresentaram resultados satisfatórios somente com a invenção de uma máquina específica para a fiação do linho. Ela foi criada por um engenheiro francês chamado Philippe de Girard, em Hirtenberg, na Áustria (Palma, 2003). 
Figura 5: Fibra do linho.

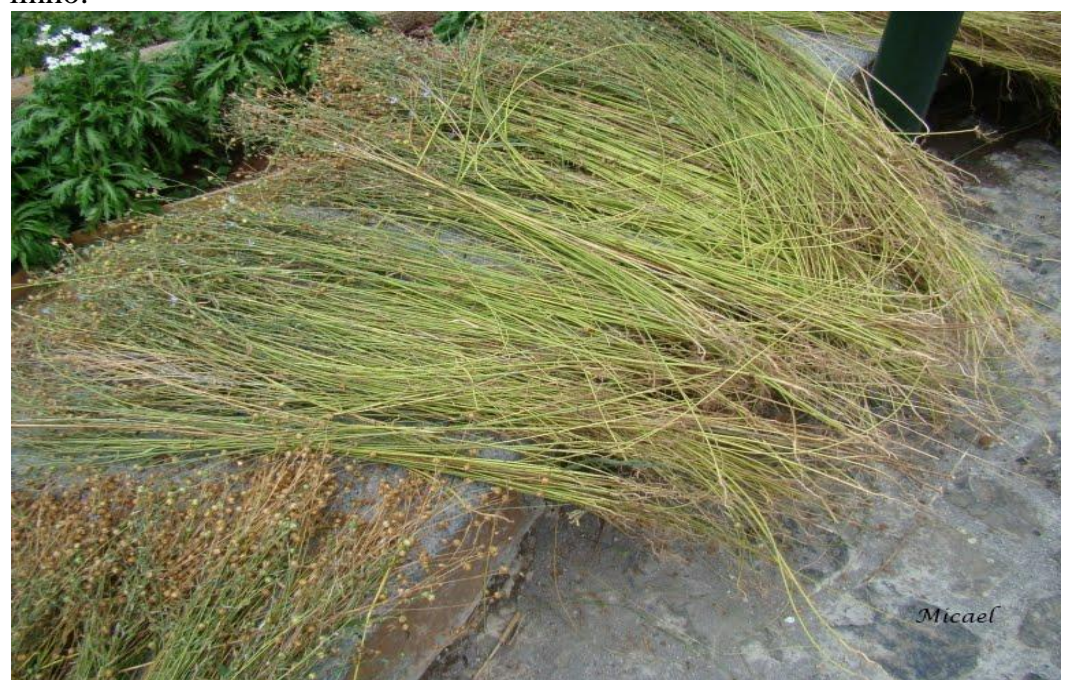

Fonte: <http://alessandrafaria.com/2012/08/a-volta-dos-tecidos-naturais/>, acesso em 18 nov. 2013 às 18 h43.

Figura 6: Fabricação do tecido do linho.

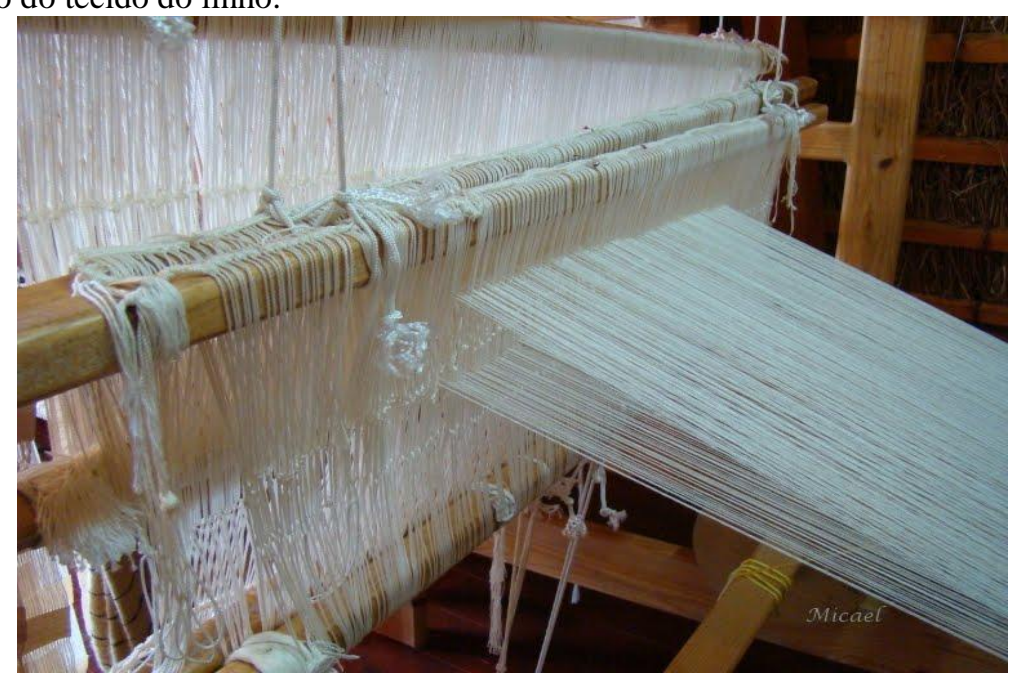

Fonte: <http://oqueenosso.blogspot.com.br/2009/05/linho-e-o-seu-fabrico.html>, acesso em 19 nov. 2013, às $21 \mathrm{~h} 57$. 
Figura 7: Fibra de linho e tecido de linho.
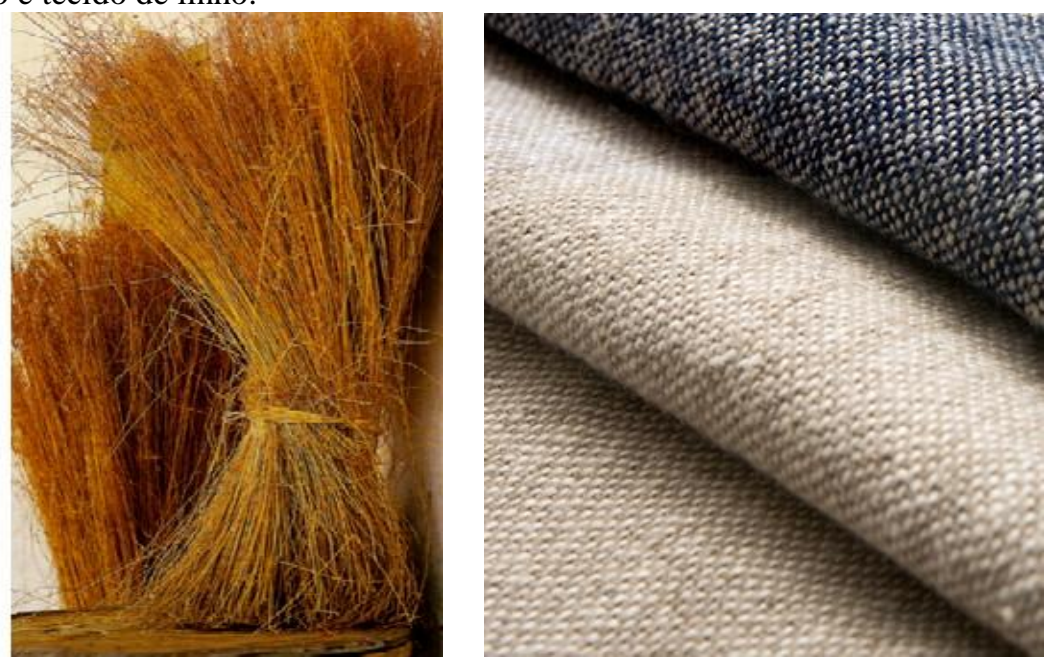

Fonte: <http://oqueenosso.blogspot.com.br/2009/05/linho-e-o-seu-fabrico.html>, acesso em 20 nov. 2013, às 06h42. <http://www.artenata.com.br/materiais/tecidos/>, acesso em 20 nov. 2013, às 08h32.

A flor do linho é o que se pode chamar de capricho da natureza. A resistência das fibras da planta é inversamente proporcional à delicadeza e à suavidade de suas flores. A flor do linho começa a desabrochar logo à primeira luz do dia, e às 10 horas atinge a plenitude de sua forma. Assim permanece por duas ou três horas, como que por encanto, e a partir desse momento encerra sua missão no ciclo de vida da planta.

Figura 8: Flor do linho e plantação de linho.
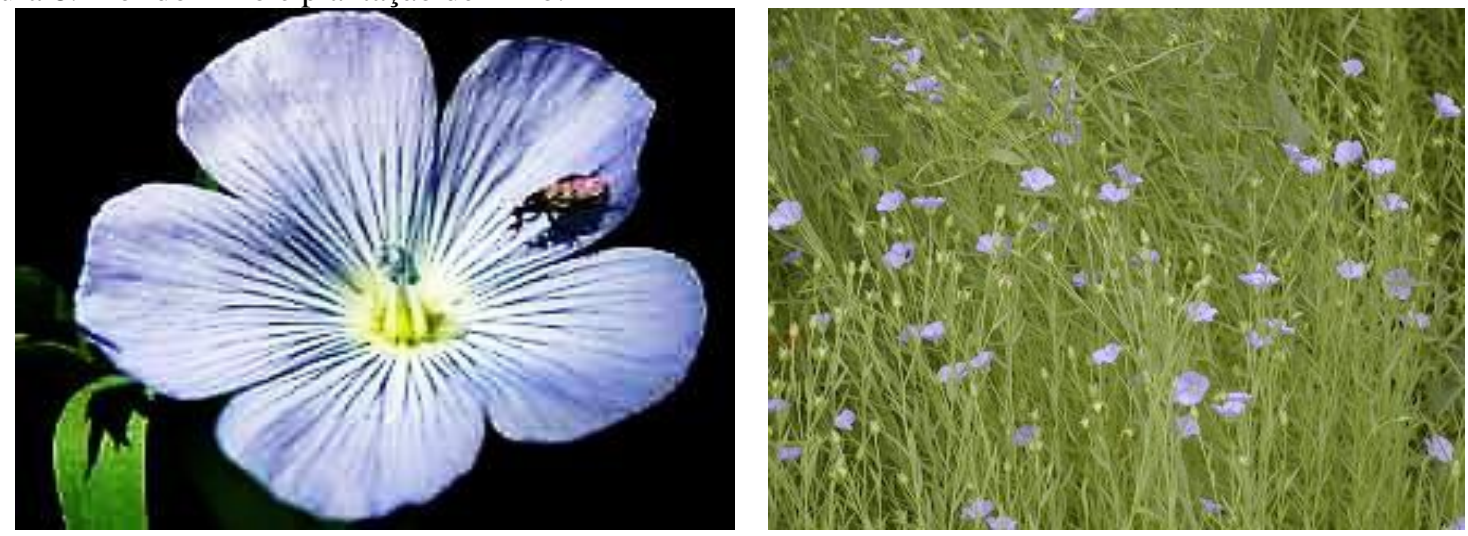

Fonte: <http://svbeira.no.sapo.pt/tecelagem.htm>, acesso em 20 nov. 2013, às 17h40. Fonte: <http://contosdefadasnaodereis.blogspot.com.br/2011/05/linho.html>, acesso em 20 nov. 2013, às $12 \mathrm{~h} 15$.

O rami pertencente à família do linho e, segundo o mesmo autor, também é uma planta fibrosa cujo caule apresenta aspecto mais rude.

Possui alta resistência, considerada três vezes superior à do cânhamo, quatro vezes superior à do linho e oito vezes superior à do algodão.

O rami pode ser utilizado em diversos segmentos: 
- Fabricação de tecidos;

- Fabricação de cordas e barbantes;

- Geração de celulose para a produção do papel moeda;

- Fabricação de mangueiras, pneus e fios de paraquedas.

O rami é mais abrasivo do que o linho, de forma que os tecidos confeccionados com ele são mais ásperos e menos agradáveis ao uso, embora essas características possam ser bastante minimizadas por meio de processos de acabamento e pela mistura com algumas fibras químicas. Apesar dessas características, os tecidos são facilmente laváveis, apresentando grande vantagem na retenção de corantes, em comparação a qualquer outra fibra vegetal. Além disso, sua aplicação é extremamente adequada nos países de clima quente, como o Brasil.

Os tecidos de rami têm boa aceitação no mercado. Por isso, o rami pode ser considerado um produto substituto muito próximo do linho, em função de suas especificações, com a vantagem de ser mais barato. É normalmente vendido com o nome de "linho" ou "linho-rami", pois normalmente o consumidor final não sabe distinguir com tanta propriedade o rami do linho, seja como produto final acabado e pronto para o consumo, seja como substrato têxtil, pronto para ser confeccionado.

Figura 9: Folha do rami.

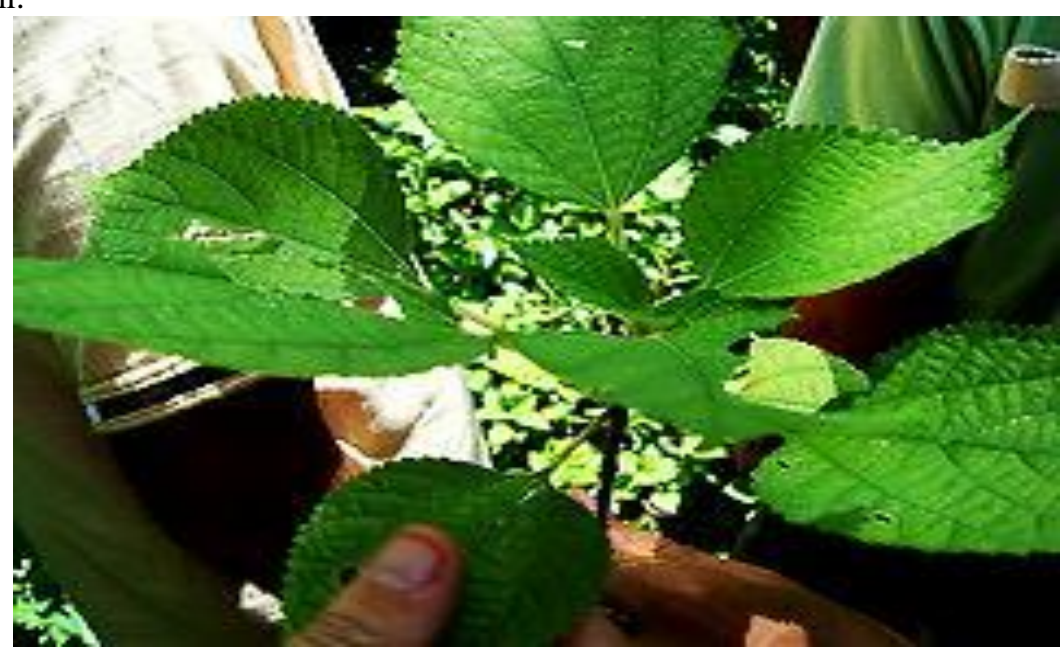

Fonte: <http://portuguese.alibaba.com/product-gs/30-ramie-leaf-extract-powder-538975400.htm>, acesso em 21 nov. 2013; às $13 \mathrm{~h} 15$. 
Figura 10: Plantação de rami.

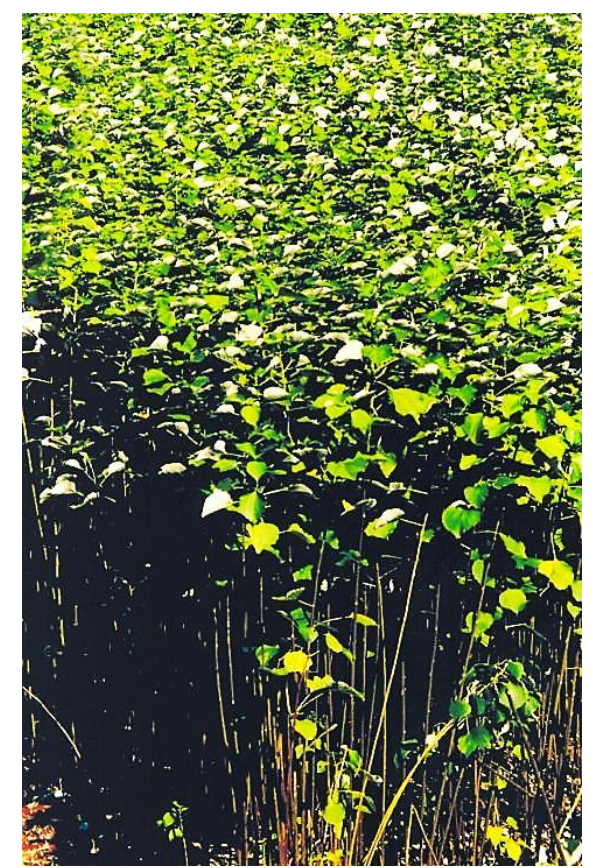

Fonte: <http://www.alternativarural.com.br/RAMI/prod-702588/>, acesso em 21 Nov. 2013, às 15 h57.

O cânhamo é uma planta têxtil conhecida desde a mais remota antiguidade. Seu centro de origem foi a Ásia, onde era cultivado muitos anos antes da Era Cristã. Acredita-se que mongóis e japoneses o conheceram antes mesmo da seda e do algodão.

É um planta que tem os sexos separados em plantas distintas. As plantas femininas são mais vigorosas e amadurecem depois das plantas masculinas. Uma subespécie do cânhamo é o cânhamo-da-Índia, que fornece o narcótico denominado haxixe.

De acordo com o mesmo autor, o Brasil possui condições climáticas e de solo ideais para a produção da planta.

O cânhamo possui um rápido ciclo de produção, que dura apenas cerca de três meses. Outra vantagem da plantação está na dispensa de agrotóxicos e de herbicidas para o seu crescimento sadio, pois a planta não é suscetível a pragas.

As fibras do cânhamo oferecem também a possibilidade de serem abertas, promovendo-se um processo de cotonização que as torna tão macias e confortáveis quanto as fibras do algodão, - bem diferente de seu estado natural, quando são ásperas e grossas como as do rami. 
Figura 11: Caule do cânhamo e fibra do cânhamo.
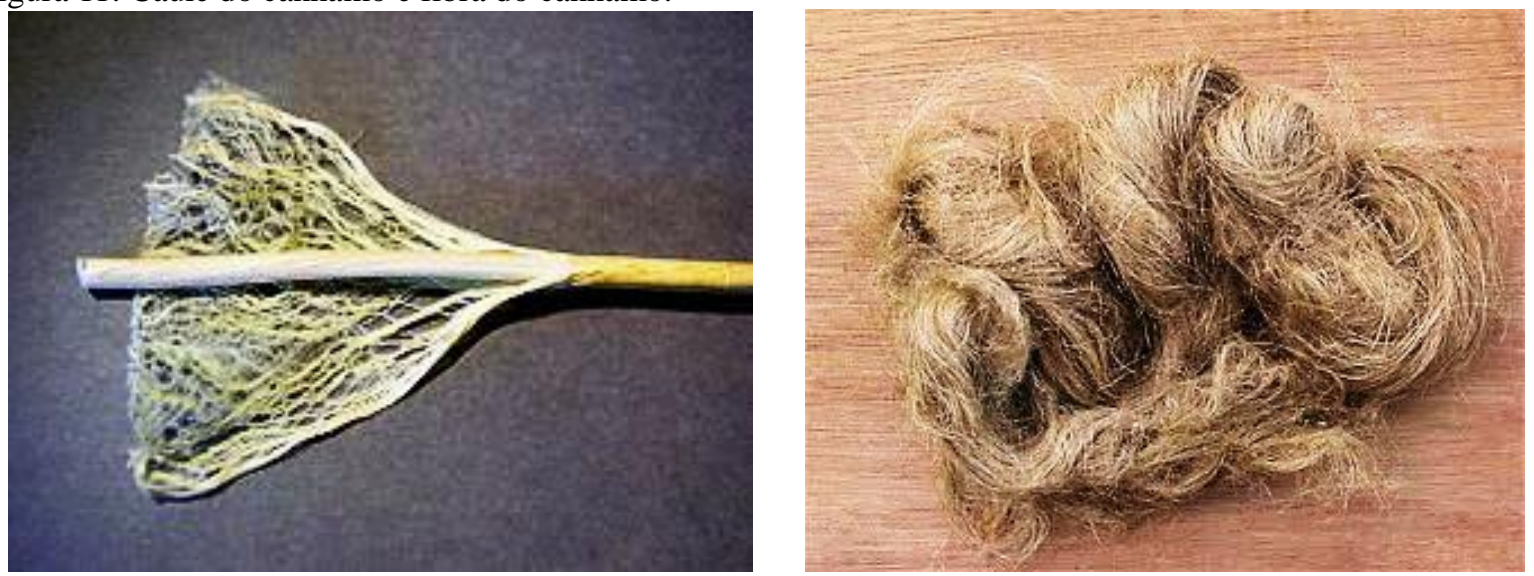

Fonte: <http://exame.abril.com.br/mundo/noticias/casal-usa-canhamo-para-construir-casa-na-australia/>, acesso em 21 nov. 2013, às 17h21. <http://bioplasticnews.blogspot.com.br/2011/05/bioplastico-de-canhamo.html>, acesso em 21 nov. 2013, às $18 \mathrm{~h} 39$.

Figura 12: Semente do cânhamo e plantação de cânhamo.
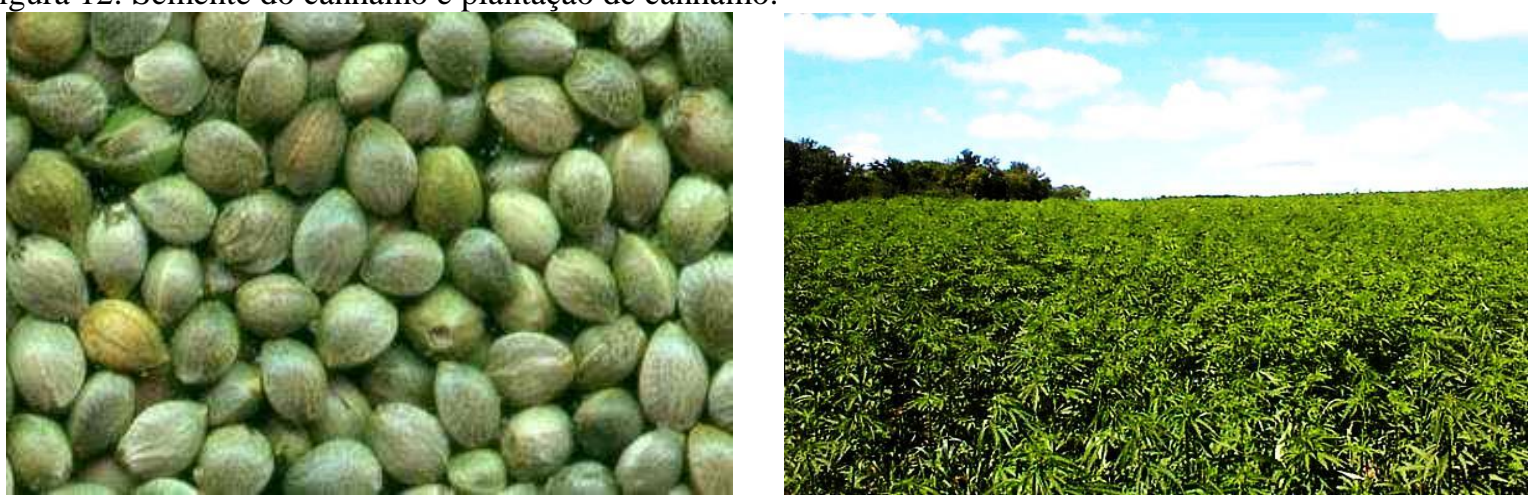

Fonte: <http://avesdoronda.weebly.com/cacircnhamo.html>, acesso em 21 nov. 2013, às $20 \mathrm{~h} 15$.

<http://lucianaduarte.wordpress.com/2011/05/31/tudo-sobre-a-malha-e-o-tecido-de-canhamo/>, acesso em 21 nov. 2013, às 20h12.

Pode-se ainda mencionar, entre as fibras naturais vegetais:

- Juta;

- Coco;

- Sisal;

- Abacaxi.

Trata-se de fibras utilizadas em pequenos setores que exijam fabricação em escala industrial e comercial (PALMA, 2003).

\subsubsection{Fibras animais}


São exemplos de fibras naturais animais a seda e a lã.

Os primeiros a conhecerem a seda foram os chineses. Descobriram que podiam fabricar com ela um tecido para fazer vestidos, e desenvolveram um método de extraí-la dos animais que as produziam.

A palavra seda é usada para denominar as secreções de filamentos produzidas por alguns tipos de invertebrados.

Entre os invertebrados que secretam a seda podemos destacar:

- Bicho da amoreira. O nome científico desta lagarta é Bombyx mori Linnaeus. É conhecida popularmente como bicho-da-seda;

- Antheraea pernyi Guerin: bicho-da-seda ou tasar chinês;

- Antheraea myllita Drury ou bicho-da-seda do tasar;

- Antheraea yamamai Guerin ou bicho-da-seda tasar japonês;

- Antheraea assama Helfer ou bicho-da-seda mouga;

- Atlacus ricini Boisduval ou bicho-da-seda eri;

- Philosamia ricini Drury ou bicho-da-seda eri;

- Eriogyma pyretorum Wood ou bicho-da-seda linha de pesca;

- Lagarta do carvalho;

- Aranha.

A espécie mais conhecida e popular utilizada na fabricação da seda é a Bombyx mori Linnaeus. Esta pode ser classificada por sua origem, voltinismo, número de ecdises ou de mudas, morfologia e fisiologia do bicho-da-seda e biologia do bicho-da-seda.

A classificação por origens é dada da seguinte forma: japonesa, chinesa, europeia, indiana ou equatorial e coreana.

Quando a classificação é feita por voltinismo, é possível dividi-la em três grupos:

- Monovoltino (um ciclo anual) - ocorre nas regiões frias; ciclo larval mais longo, maior crescimento do corpo, boa qualidade dos casulos, menor resistência a doenças e a altas temperaturas e umidade; 
- Bivoltino (dois ciclos anuais) - ocorre nas regiões subtropicais; ciclo lagarta menor, maior resistência ao calor, qualidade inferior dos casulos, mais utilizada pelos sericultores;

- Polivoltino (vários ciclos anuais) - ocorre nas regiões tropicais; ciclo da lagarta curto, maior resistência a doenças e ao calor, casulos pequenos, baixo teor de seda.

Quando se classifica pelo número de ecdises ou de mudas, é possível dividir de duas formas: três ecdises, quatro ecdises ou cinco ecdises.

- Três ecdises: circo larval mais curto, resistente a doenças, lagartas e casulos pequenos, fibra mais fina, espécie de origem coreana e chinesa;

- Quatro ecdises: mais utilizada pelos criadores, lagartas e casulos médios;

- Cinco ecdises: mutação da origem de quatro ecdises, lagarta de ciclo longo, casulos maiores, fibra mais grossa.

As características da morfologia e fisiologia do bicho-da-seda se dão mediante análise do ovo, lagarta, pupa ou crisálida do animal durante o seu crescimento.

As características da biologia do bicho da seda podem ser analisadas levando-se em conta seu ciclo de vida.

Atualmente, pode-se comprovar o avanço das pesquisas relacionadas à introdução da fibra na indústria têxtil. Ela já vem sendo testada e é apontada como potencial substrato têxtil para a confecção de coletes à prova de balas. A fibra é comprovadamente tão resistente quanto o aço e tão sedosa como a seda produzida pelo bicho-da-seda da amoreira.

A descoberta da seda ocorreu aproximadamente no ano 2600 a.C., quando o imperador chinês Hwang-Te confiou a criação do bicho-da-seda a sua esposa, Hish-Ling-Shi. Os chineses observaram que as lagartas podiam viver, prosperar e se reproduzir em cativeiro, desde que bem alimentadas com folhas de amoreira.

Para dar uma ideia da dimensão da produção, a partir de 30 gramas de ovos saem aproximadamente 40 mil insetos, que devoram, em oito semanas, 350 quilos de folhas.

Quando a lagarta nasce, não pesa mais do que a décima parte de um miligrama. Na fase adulta, com um comprimento de nove centímetros, ela pesa 10 gramas, transformando-se, então, em crisálida, quando por fim fia a famosa seda.

Os chineses guardaram seus conhecimentos fielmente, pois o único desejo da nação era ser o único país produtor de seda e exportá-la para todo o mundo.

A seda era transportada por terra, atravessando o Himalaia, a Índia e a Pérsia até 
chegar à Turquia, à Grécia e também a Roma. O percurso ficou conhecido como "Rota da Seda".

De acordo com o mesmo autor, no ano 550, o imperador romano Justiano resolveu implantar a indústria da seda no império do Oriente e, para isso, enviou secretamente dois frades persas à China. Sua missão era trazer alguns ovos do bicho-da-seda, assim como reunir os conhecimentos necessários para a sua criação.

Quando conseguiram a quantidade desejada, os dois frades retornaram com os ovos escondidos em um bambu, levando-os para Constantinopla. Após incubados, a criação desenvolveu-se, tendo sido confiada a amigos do imperador. Com o tempo, o conhecimento espalhou-se por outros países, não estando mais a criação do bicho-da-seda restrita a um só país.

\subsubsection{Formação do Fio}

A lagarta produtora do fio da seda forma dois vasos ou cascos, colocados ao comprido de cada lado do seu corpo e que se enchem de um líquido pegajoso. Saem desse espaço, através dos orifícios, dois pequenos fios de uma espécie de baba, que provém daqueles sacos (PALMA, 2003).

O inseto começa a tecer seu casulo, soltando dois fios sedosos pelos orifícios pequeníssimos, juntando-os em um só. Com esse material, a lagarta constrói uma cômoda e macia habitação. Ela demora de três a cinco dias, de maneira que, ao terminar o casulo, nele fica fechada e completamente invisível. A lagarta perde 50\% de seu peso entre o início e o fim do processo.

O casulo é uma viçosa bola de seda, resistente ao tato, em forma de ovo e normalmente de cor esbranquiçada ou amarelada. Se não tocado ou destruído por qualquer predador, depois de duas ou três semanas sairá dali de dentro uma pequena borboleta.

Para a produção da seda, é necessária a intervenção humana, que interrompe o processo natural a fim de se obter a matéria-prima (PALMA, 2003). 
Figura 13: Amoreira.

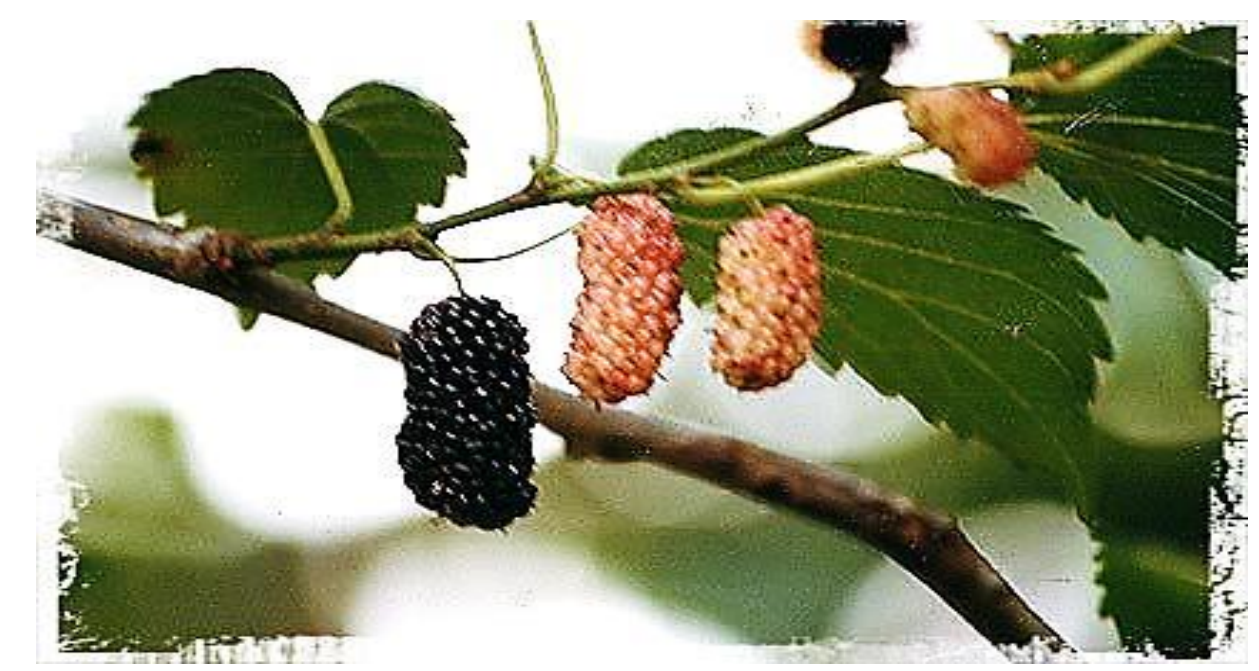

Fonte: <http://www.plantasmedicinaisefitoterapia.com/plantas-medicinais-amora.html>, acesso em 21 nov. 2013 , às $18 \mathrm{~h} 37$.

Figura 14: Casulo e casulos prontos para o banho de preparo da seda.

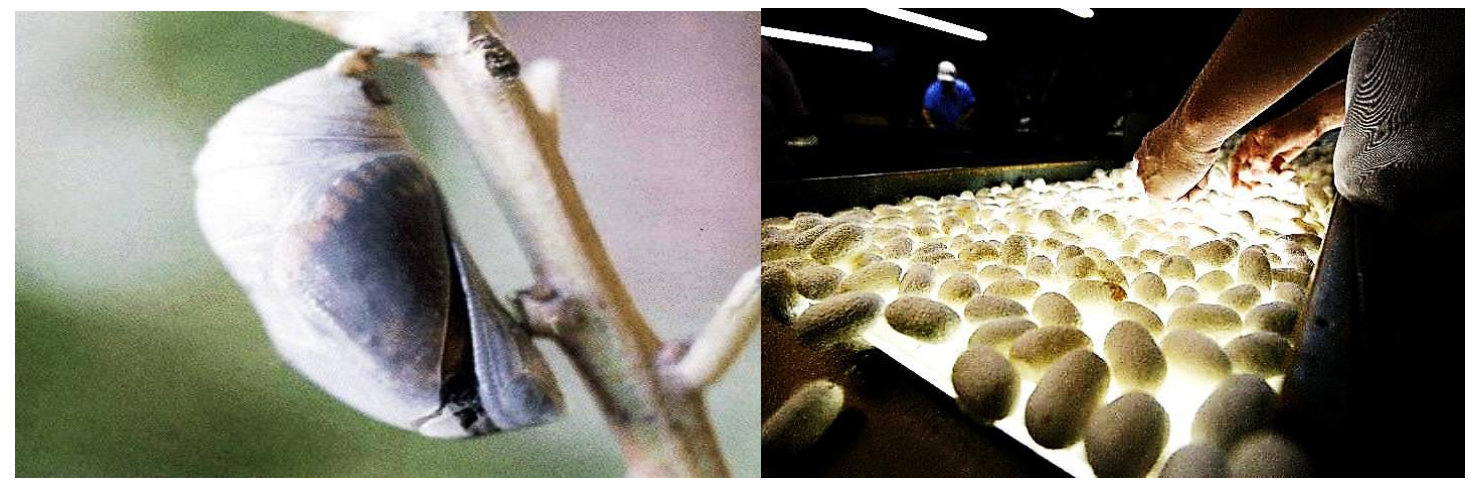

Fonte: <http://chc.cienciahoje.uol.com.br/preparadas-para-mudar/>, acesso em 24 nov. 2013, às 05h39.

$<$ http://topicos.estadao.com.br/fotos-sobre-seda/producao-de-seda-da-fabrica-japonesa-bratac-a-maior-dobrasil,0016fe1b-b8ce-458f-8dec-4ff83267b697>, acesso em 24 nov.2013, às 05h47.

Figura 15. Seda em formato de tecido.

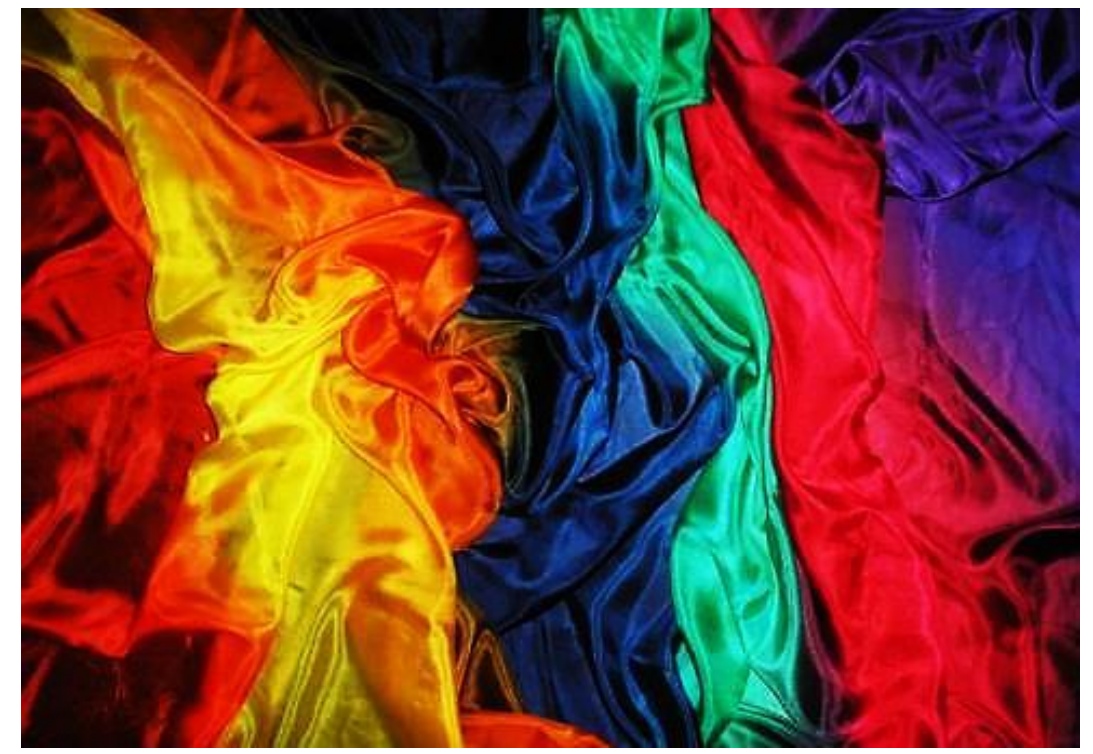

Fonte: <http://portuguese.alibaba.com/product-gs/pure-silk-fabric-285125448.html>, acesso em 24 nov. 2013 , às 
09h13.

Embriagados pelo fascínio desse fio extremamente fino, os orientais contam a seguinte lenda:

Certa manhã, um casulo caiu na xícara de chá de uma princesa. Com o calor da bebida, ele começou a derreter; a princesa tentou retirá-lo dali e um fio se soltou. Ela começou a puxar o casulo e este foi se desenrolando. Encantada com a beleza e a espessura do fio, a princesa mandou tecer um manto para o seu amado. Nasceu assim, o primeiro tecido feito de seda pura. (PALMA, 2003, p.34)

A lã consiste em uma fibra proteica, retirada de carneiros e ovelhas (PALMA, 2003). Sua composição média é:

Carbono..............50\%
Hidrogênio...........7\%
Oxigênio..............de 22 a $25 \%$
Nitrogênio............de 16 a $17 \%$
Enxofre................de 2 a $4 \%$

Inicialmente, aparece como material têxtil bem qualificado apenas na Índia sobretudo no Himalaia e nas montanhas da Caxemira, onde se fabricavam tecidos de excelente qualidade, exportados para o Irã e países Mediterrâneos - e na Ásia Ocidental, principalmente na Mesopotâmia, onde divide com o linho o papel de fibra mais utilizada. No Egito, apesar de ser conhecida e utilizada, não era tão importante como o linho, seja por razões religiosas, como afirma Heródoto, ou porque os tecidos de lã eram menos adequados às condições climáticas do país. No mundo greco-romano, a lã constituía um dos têxteis mais valorizados do vestuário.

De acordo com a raça da ovelha, obtêm-se fibras de comprimentos diferentes. $\mathrm{O}$ processo de obtenção da fibra de origem animal funciona da seguinte maneira: a lã é extraída das ovelhas por um processo denominado tosquia, que é o corte do pelo do animal. A operação é geralmente realizada duas vezes ao ano, podendo-se obter de 5 a 10 quilos de lã por ano por animal, dependendo da sua raça.

Para o mesmo autor, a qualidade da fibra varia. A "lã morta" ou "pelego", obtida por 
meio de processos químicos ou mecânicos, é mais dura e quebradiça do que a "lã viva" ou "de velo", extraída por tosquia manual. Independente do processo de extração, a lã geralmente chega às fiações em estado bruto.

\subsubsection{Fiação manual da lã}

Normalmente se faz um processo de seleção manual, ou triagem, para separar a lã de acordo com a sua qualidade, pois mesmo a lã de uma única ovelha não é homogênea. A melhor qualidade vem da região dos flancos do animal. A lã da espádua, do pescoço e do dorso é constituída de fibras cuja qualidade é tida como inferior; enquanto a dos quadris, das pernas e da barriga é composta por fios geralmente embaraçados e sujos, sendo necessário, muitas vezes, se desfazer das fibras oriundas dessas regiões, por apresentarem aspectos de sujeira e encardimento (PALMA, 2003).

Outro processo de seleção é a cor, já que a lã é facilmente encontrada em vários matizes de marrom e bege, também variando do branco ao preto.

É necessário lavar as fibras com água morna e sabão para a retirada da gordura existente (lanolina). Deve-se ter o cuidado de não ferver a lã, pois ela corre o risco de "feltrar".

Depois que a fibra seca, é comum abri-la com os dedos. Esse processo serve para desembaraçar as fibras e eliminar impurezas. Ao cardar, completam-se inicialmente o destrinçamento das fibras e, posteriormente, sua limpeza, desfazendo-se nós e limpando-se ainda mais as fibras ao se retirar o restante de suas impurezas. A cardação permite que se forme uma fita ou pasta homogênea própria para ser fiada. Para cardar, empregam-se duas escovas com fio de aço, denominadas "cardas", que penteiam a lã eliminando todos os nós, destrinçando-a e deixando-a pronta para ser fiada. Algodão, lã e linho são cardados de acordo com a mesma técnica (PALMA, 2003).

A fiação consiste na transformação da pasta em fio, por meio do retorcimento e alongamento das fibras. A torção confere ao fio resistência à tração, pois faz com que as fibras se apertem umas contra as outras. Uma vez fiados, os fios vão sendo enrolados em novelos. A fiação pode ser feita mediante uso do fuso ou da roca, que é geralmente acionada por um pedal.

Mohair é o nome da lã obtida dos pelos das cabras de Angorá (Ancara, capital da Turquia).

Pashmina é o nome de um xale feito com barbas de cabras da região da Caxemira, na 
Índia.

Figura 16: Animal em processo de tosa.

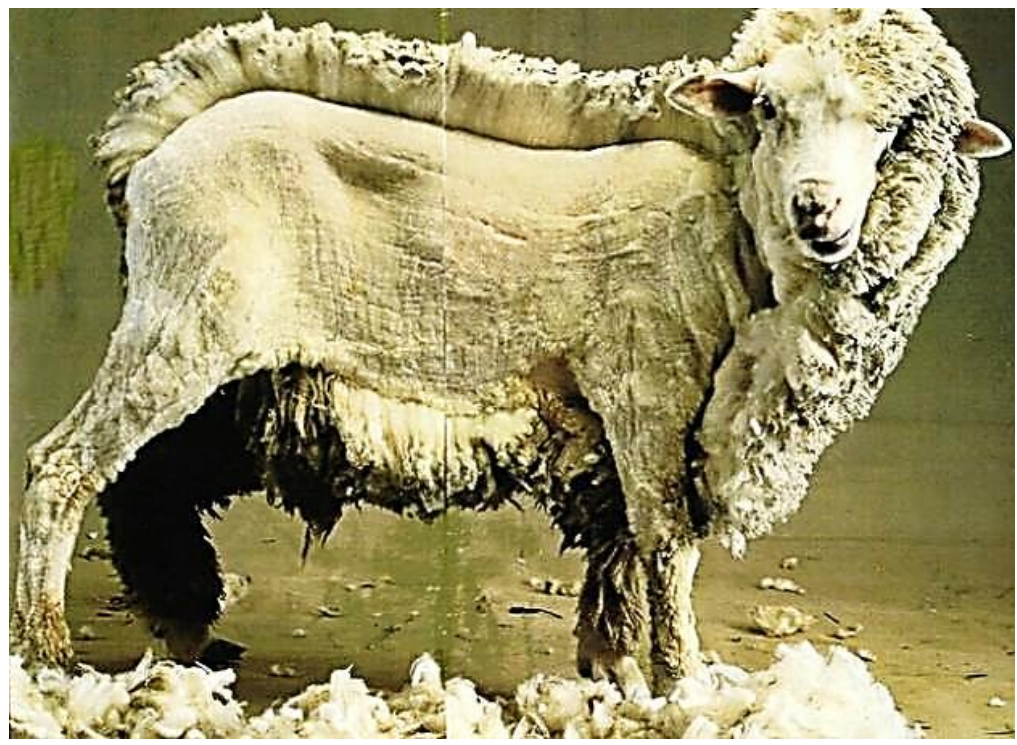

Fonte: <http://lapizdecor.wordpress.com/category/tosquia/>, acesso em 24 nov. 2013, às $23 \mathrm{~h} 37$.

Figura 17: Tosquia da ovelha.

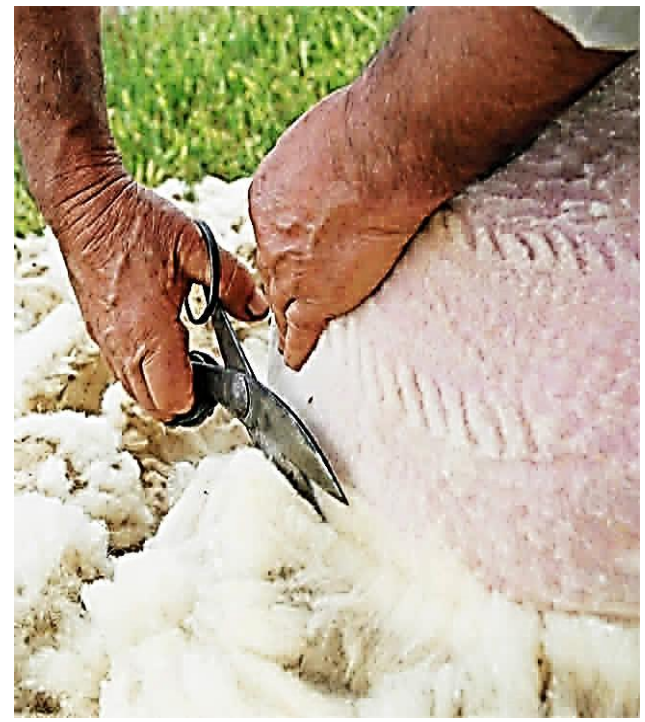

Fonte: <http://bicharada.net/animais/pop.pix.php?f=8570>, acesso em: 25 nov. 2013, às 08h16.

<http://acurvadasletras.blogspot.com.br/2010/08/tambem-tens-medo-sergio.html>, acesso em: 25 nov. 2013, às $09 \mathrm{~h} 14$.

\subsubsection{Fibras minerais}

Podemos relacionar como exemplo de fibra natural mineral o amianto.

De acordo com Giannasi (1999), amianto é o nome comercial dos minerais formados basicamente por silicatos de magnésio, possuindo uma parte fibrosa chamada cabelo ou pedra 
cabeluda e outra parte sólida. É conhecido também como asbesto, sido utilizado desde os tempos mais remotos, quando o homem adicionava o asbesto à argila para produzir artefatos refratários.

Nos últimos cem anos a utilização do amianto se disseminou e cresceu muito em todo o mundo. Estima-se que mais de 3000 materiais e objetos tenham nesse mineral sua base de constituição (GIANNASI, 1999).

Segundo Castro (1997), a ampla e versátil utilização deste material ocorre, sobretudo, em decorrência de suas propriedades físicas únicas. É um material isolante de calor, possui alta resistência mecânica e baixa condutibilidade elétrica, resiste bem a substâncias químicas agressivas, é capaz de filtrar micro-organismos e outras substâncias nocivas. Ademais, sua mineração é simples e de baixo custo, já que as rochas são encontradas a céu aberto.

D'-Acri e Castro (2001) salientam que essas características do amianto o tornam um produto muito utilizado industrial e comercialmente. No Brasil, ele é empregado em muitos produtos, principalmente na indústria de fibrocimento, como: caixas de água, telhas, tubos de água e vasos; na indústria têxtil: tecidos em geral, confecção de luvas industriais, roupas para bombeiros e gaxetas; na produção de papéis: papéis isolantes, papelão hidráulico, papelão industrial, filtros; na indústria automobilística: pastilhas e lonas de freios para automóveis, materiais de fricção, sapatas de trens, juntas de vedação; na produção de pisos vinílicos e outros produtos.

Porém, de acordo com o INCA - Instituto Nacional do Câncer, é em decorrência da exposição do manipulador da matéria-prima que se corre o risco da obtenção de doenças, em virtude do contato com o pó que é liberado.

\section{$\underline{\text { Formas de exposição ao meio ambiente }}$}

- Exposição ocupacional:

$\checkmark$ a exposição ocupacional é a principal forma de exposição e contaminação;

$\checkmark$ ocorre, principalmente, pela inalação das fibras de amianto, que podem causar lesões nos pulmões e em outros órgãos;

$\checkmark$ a via digestiva também deve ser considerada como fonte de contaminação.

- Exposição ambiental:

$\checkmark$ contato dos familiares com roupas e objetos dos trabalhadores contaminados pela fibra; 
$\checkmark$ residir nas proximidades de fábricas, minerações ou em áreas contaminadas (solo e ar) por amianto;

$\checkmark$ frequentar ambientes onde haja produtos de amianto degradados;

$\checkmark$ presença do amianto livre na natureza ou em pontos de depósito ou descarte de produtos com amianto.

O amianto é um material fibroso extraído de depósitos rochosos. Quimicamente falando, o amianto de crisólita (utilizado no processamento têxtil) é um silicato hidratado de magnésio, que contém pequenas porções de óxido férrico e de alumínio.

O amianto não queima, podendo ser fiado e tecido. É utilizado como material isolante e como tecido para a fabricação de roupas de proteção contra o fogo (bombeiros, astronautas, corredores de Fórmula 1, entre outros), lonas de freio e fricção.

Figura 18: Pedra de amianto (à esq.) e fibra de amianto (à dir.).
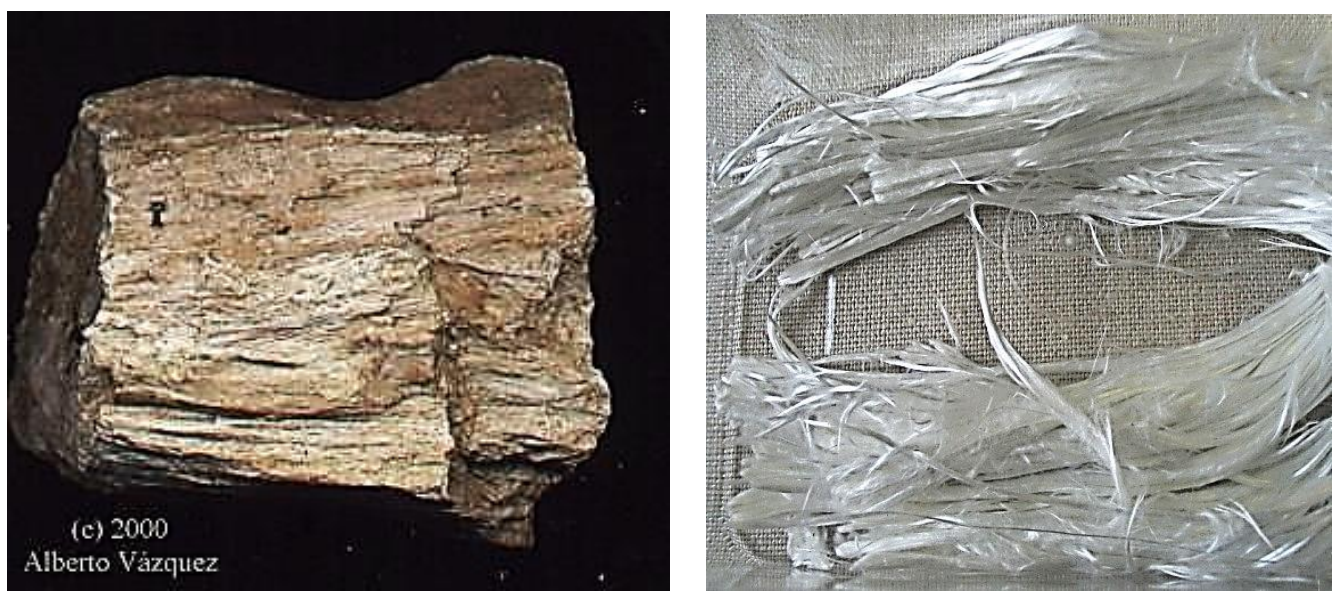

Fonte: <http://andremansur.com/blog/carregador-de-pedras-de-amianto-nao-prova-adoecimento-por-peso-emexcesso/>, Acesso em 25 nov. 2013, às 22h57. Fonte:

<http://www.noticiasburgos.com/hemeroteca/tabid/303/ctl/articleview/mid/777/articleid/13926/aranda-de-dueroacoge-una-jornada-tecnica-sobre-trabajos-con-amianto.aspx>, acesso em 25 nov. 2013, às 14 h47.

Figura 19: Fibra de amianto (à esq.) e macacão confeccionado com fibra de amianto (à dir.). 

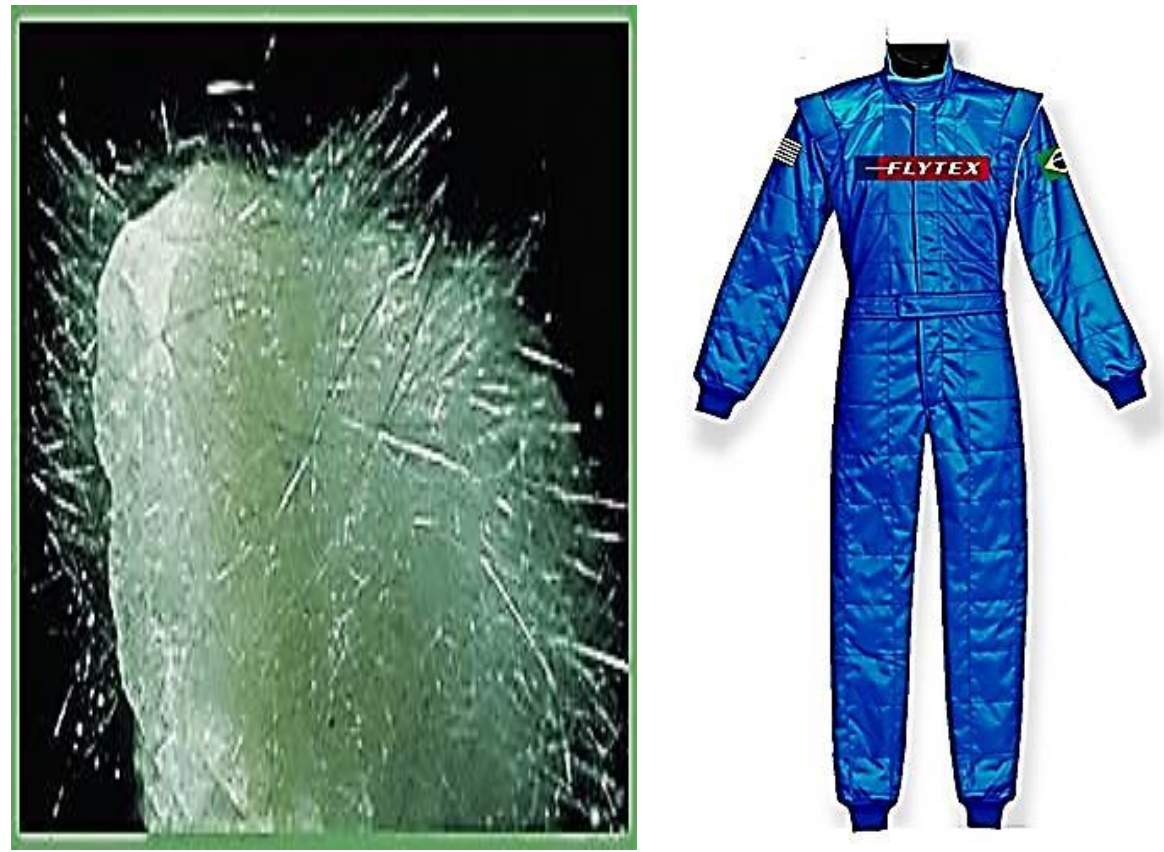

Fonte: <http://www.brasilescola.com/curiosidades/o-amianto-usado-caixas-dagua-cancerigeno.htm>, acesso em 26 nov. 2013, às 07h39. <http://www.ufo.com.br/artigos/pele-roupa-ou-computador>, acesso em 26 nov. 2013, às $14 \mathrm{~h} 13$.

\subsubsection{Fibras artificiais}

São fibras químicas obtidas da celulose quimicamente tratada, regenerada ou modificada. A fonte de celulose de que se lança mão tanto pode ser a polpa da madeira quanto as diminutas ramas do algodão (PALMA, 2003).

Para o mesmo autor, entre inúmeras fibras artificiais podemos destacar o rayon, a viscose, o acetato e o lyocell.

O rayon foi descoberto no final do século XIX. Surgiu de pesquisas feitas em uma cadeia de moléculas, chamadas de polímeros, extraídas de fibras têxteis naturais.

Por ter sido um dos primeiros filamentos inventados, o rayon muitas vezes aparece com o seu nome associado a outros filamentos artificiais, como rayon viscose, acetato, entre outros.

Seu processo de fabricação foi descoberto a partir da prensagem da celulose tratada quimicamente com soda cáustica e extrudada em máquinas especiais.

Todas as fibras artificiais se parecem, pois são de natureza semelhante (celulósica). O que as torna diferentes umas das outras são os elementos químicos utilizados em sua fabricação.

Uma curiosidade: nos Estados Unidos, todas as fibras advindas de celulose regenerada 
são chamadas de rayon.

Figura 20: Fibra de rayon vista em microscópio (à dir.) e filamento de rayon (à esq.).

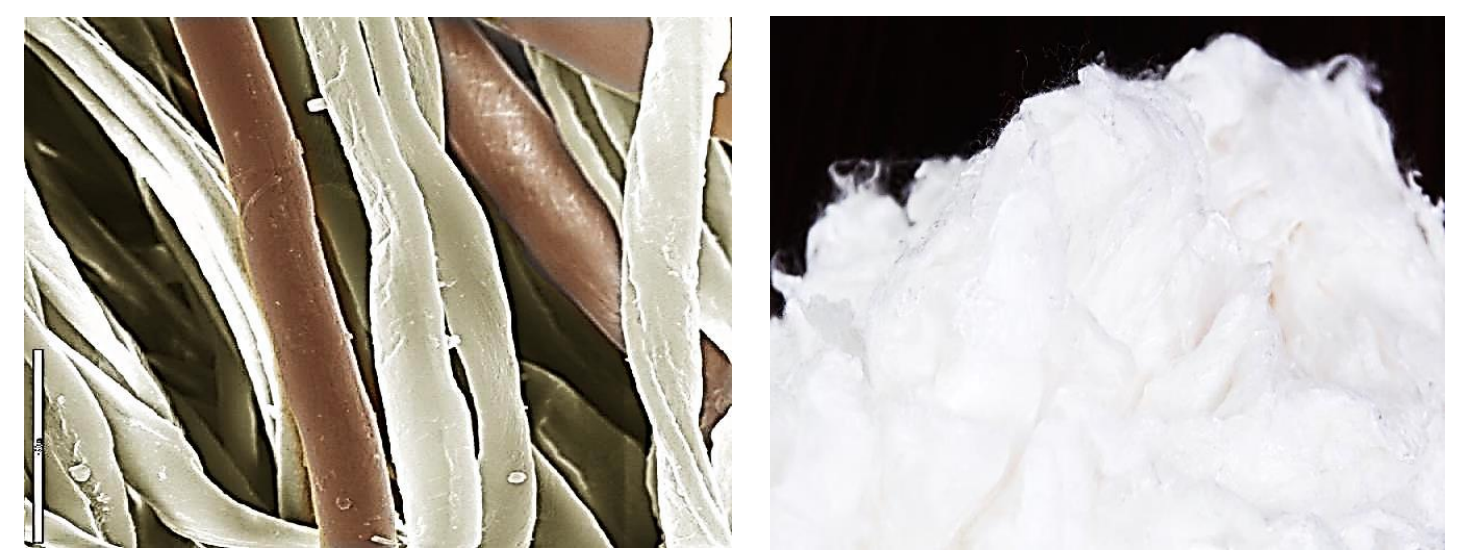

Fonte: <http://aplicacionesdelacelulosa.blogspot.com.br/2010_10_01_archive.html>, acesso em 26 nov. 2013, às 17h50. Fonte: <http://pt.made-in-china.com/co_jinghongthread/product_Rayon-EmbroideryThread_hruiygiyy.html>, acesso em: 26 nov. 2013, às 17 h59.

A viscose é um filamento artificial descoberto em 1891 pelos químicos ingleses Charles Frederick Cross e George Beadle. O processo de fabricação da viscose envolve uma pasta de madeira, que é imersa em uma solução de soda cáustica a $18 \%$ por meio de uma prensa especial. Esse procedimento produz uma celulose alcalina que pesa 3,5 vezes mais do que a celulose inicial. Segue-se, então, um tratamento com sulfato de carbono a uma temperatura de $20^{\circ} \mathrm{C}$ em batedeiras hexagonais. $\mathrm{O}$ xantato de celulose que então se forma é um composto sólido, vermelho-alaranjado, que se dissolve em uma solução de soda à temperatura ambiente. Obtém-se, então, um líquido viscoso, a viscose (PALMA, 2003).

Em seguida, é feita uma operação de filtragem e ocorre um período de amadurecimento, em temperaturas entre $15^{\circ} \mathrm{C}$ e $20^{\circ} \mathrm{C}$, após o qual a viscose é deixada em repouso, no vácuo, para a completa eliminação das bolhas de ar que porventura existam na massa e que provocariam defeitos durante a fiagem. Essa matéria fiável passa através das fieiras impelida por bombas volumétricas. As fieiras estão imersas em um banho coagulante de ácido sulfúrico e sulfato de soda em solução. Ao sair desse banho os filamentos sofrem um alongamento, consolidando-se assim a sua estrutura.

Figura 21: Fibra de viscose. 

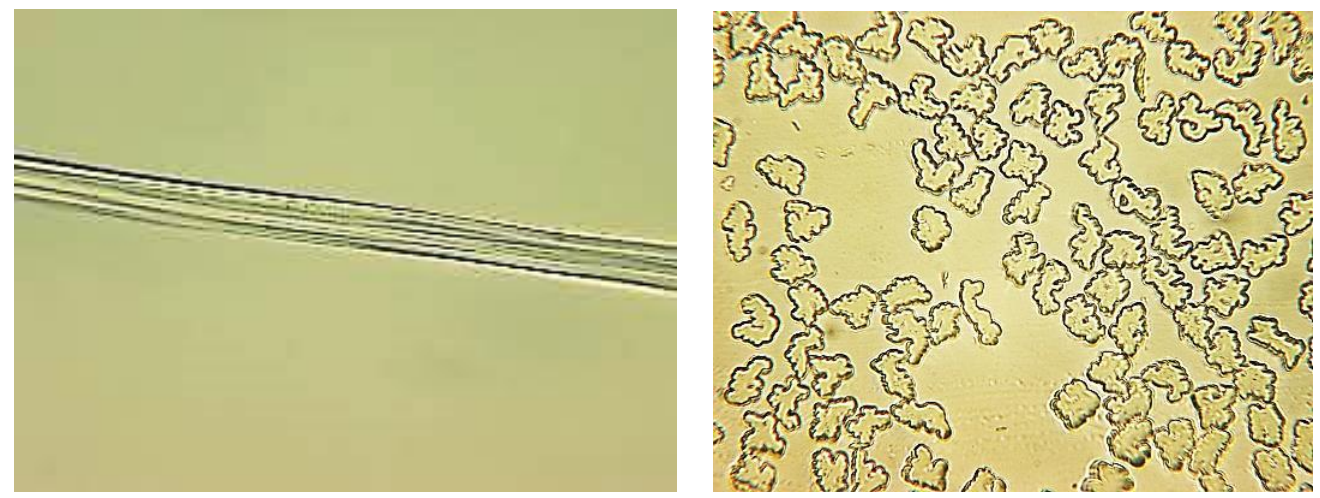

Fonte: <http://pt.texsite.info/Fibra_de_viscose>, acesso em 26 nov. 2013, às 14h42.

Figura 22: Tecido de viscose liso (à dir.) e tecido de viscose estampado (à esq.).
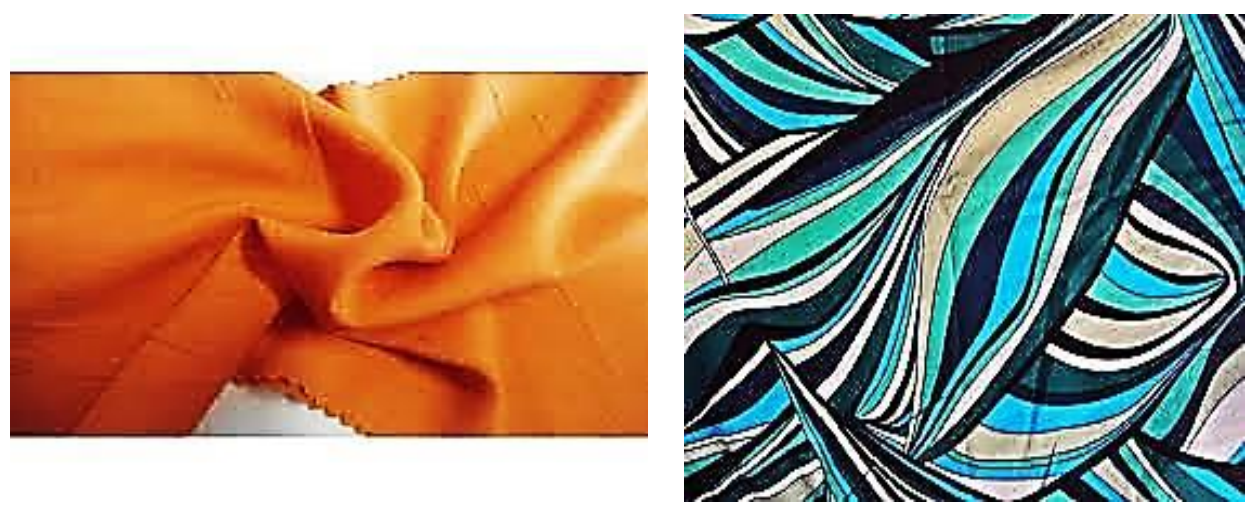

Fonte: <http://portuguese.alibaba.com/product-gs/100-viscose-dress-fabric-120d-viscose-fabric-for-fashionwear-cupro-like-viscose-fabric-662359523.html>, acesso em 27 nov 2013, às 08h39. Fonte:

<http://www.gjtecidos.com.br/viscose-estampada,product,VISC003,11005.aspx>, acesso em 27 nov. 2013, às $20 \mathrm{~h} 48$.

O acetato é uma fibra têxtil química obtida a partir de um composto químico de celulose. Seu nome originou-se de um dos produtos químicos utilizados em sua fabricação: o ácido acético.

Figura 23: Fibra de acetato.

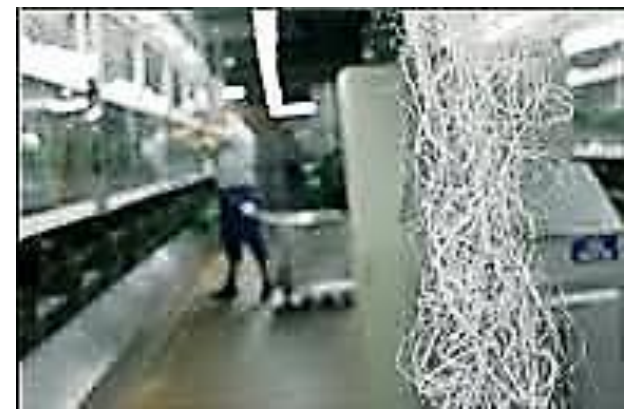

Fonte: <http://www.usefashion.com/glossario/Verbetes.aspx?IdIndice=1\&IdVerbete=4>, acesso em 27 nov. 2013, às 18 h47. 
O lyocell foi uma das últimas fibras artificiais a ser descoberta. É fabricado inteiramente de celulose natural, encontrada na polpa de madeira proveniente de árvores cultivadas especialmente para esse objetivo. Essas árvores não estão em extinção e são replantadas.

No processo de transformação em fibra, os solventes são reciclados e a efluência é mínima, inofensiva. A fibra de lyocell possui alta resistência, tanto a úmido, quanto a seco.

Figura 24: Fibra de lyocell. (à esq.) e tecido de lyocell (à dir.).
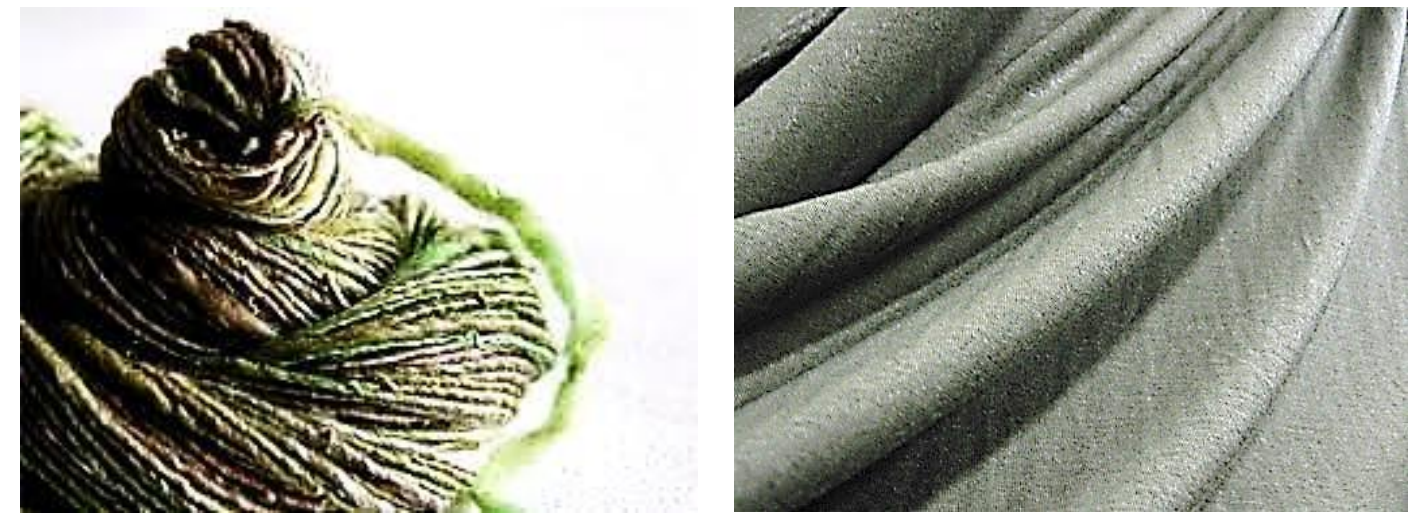

Fonte: <http://portuguese.alibaba.com/product-gs/synthetic-fibres-212737916.html>, acesso em 28 nov. 2013, às 22h22. <http://portuguese.alibaba.com/product-gs/lyocell-poly-blend-fabric-tencel-poly-fabric-twill538440637.html>, acesso em 28 nov. 2013, às $23 \mathrm{~h} 48$.

\subsubsection{Fibras sintéticas}

A fibra é chamada de sintética quando o filamento resultante do processo de extrusão (polimerização) provém basicamente de elementos naturais minerais, principalmente o petróleo e o carvão mineral.

A poliamida é uma fibra sintética obtida pelo processo de polimerização. É também conhecida com o nome comercial de nylon. Dependendo do processo de fabricação, o nylon pode receber várias nomenclaturas.

Segundo Palma (2003), o nylon 6.6 é obtido por meio da polimerização do hexametileno diamina e do ácido adípico. O nylon 6, pela polimerização do caprolactama. A formação do nylon trilobal ocorre pela forma triangular dos furos do spinneret (fieira) da fiação, ou seja, a secção transversal do spinneret determina a secção transversal da fibra.

Figura 25: Filamento de nylon. (à dir.) e fibra de nylon (à esq.). 

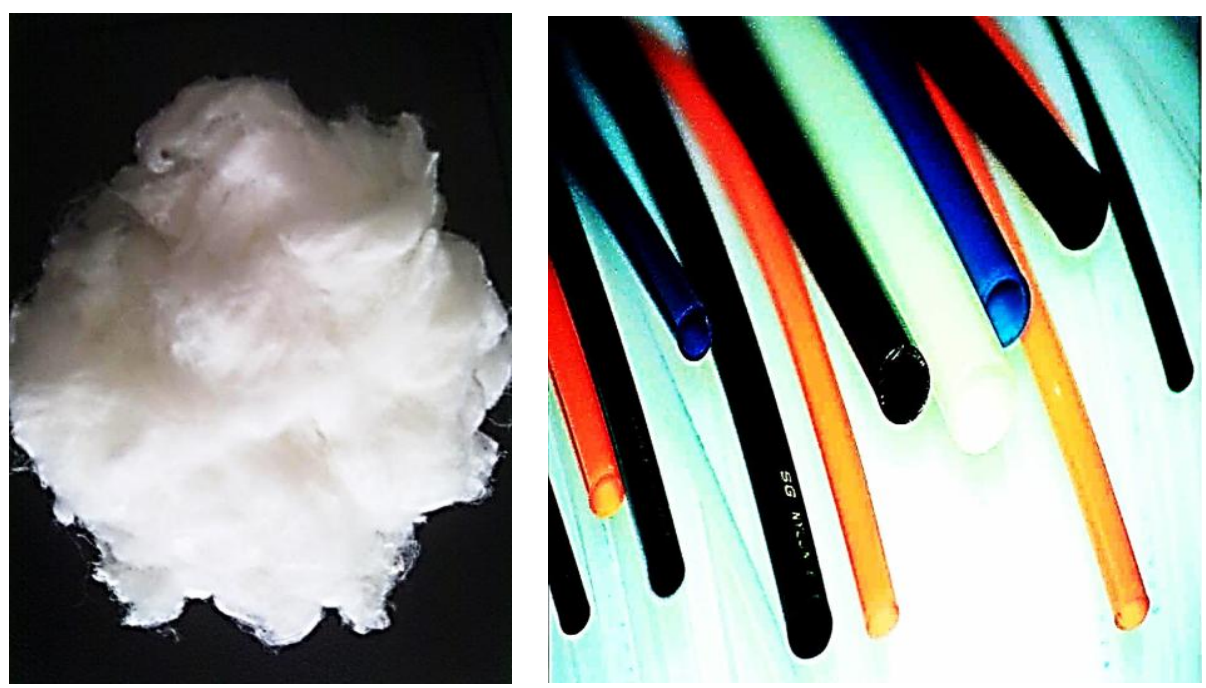

Fonte: 〈http://portuguese.alibaba.com/product-gs/nylon-fibre-302668377.html〉, acesso em 29 nov. 2013, às 18h57. 〈http://tramas100dramas.blogspot.com.br/2010/01/as-fibras.html〉, acesso em 29 nov. 2013, às $21 \mathrm{~h} 32$.

O processo de fabricação das fibras de poliéster é similar ao processo de fabricação do nylon - em muitos aspectos, ao complicado processo de fabricação do nylon. Os elementos químicos, no entanto, diferem uma fibra da outra. No poliéster, as matérias-primas utilizadas são o ácido teraftálico e o etileno-glicol (PALMA, 2003).

Figura 26: Fibra de poliéster (à dir.) e filamento de poliéster (à esq.).

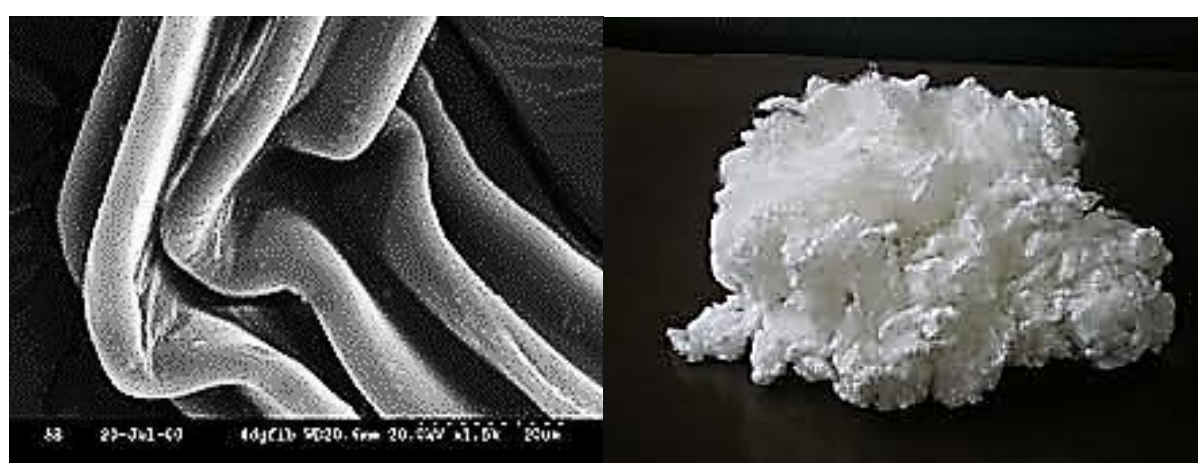

Fonte: <http://marel.zip.net/>, acesso em 29 nov. 2013, às 22h57.

Fonte: <http://www.coatsindustrial.com/pt/products-applications/industrial-threads/epic>, acesso em 29 nov. 2013, às 14 h35.

As fibras de acrílico foram criadas para que se pudesse desenvolver uma lã sintética. Elas são obtidas a partir de um composto químico denominado acrilonitrila. Esse composto, de cujo nome deriva o nome das fibras de acrílico, é feito de produtos químicos oriundos de elementos encontrados no carvão mineral, na água, no petróleo e na pedra calcária (PALMA, 2003).

As fibras de acrílico são utilizadas sob a forma de fibras cortadas em pequenos 
comprimentos.

Figura 27: Fibra de acrílico (à esq.) e manta de acrílico (acrilon) (à dir.).
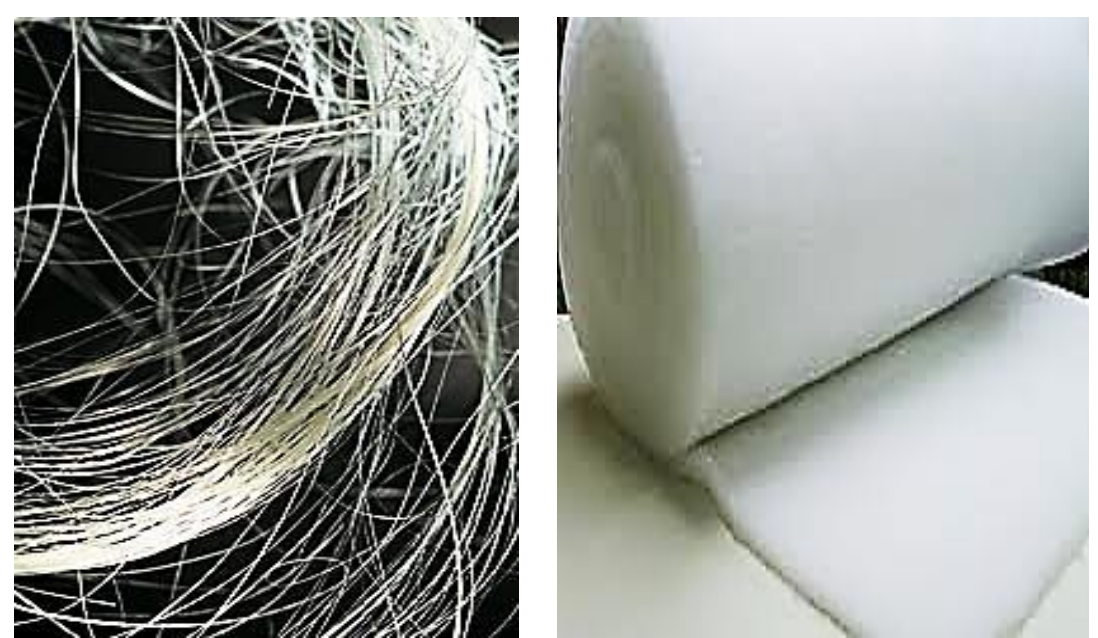

Fonte: <http://revistapesquisa.fapesp.br/2009/02/01/fio-versatil-e-limpo/>, acesso em 30 nov. 2013, às 22h47. $<\mathrm{http} / / / \mathrm{www}$.armarinhosantacecilia.com.br/manta-acrilica-por--metro/manta-acrilica.JPG/64/5959>, acesso em 30 nov. 2013, às $14 \mathrm{~h} 56$.

A aramida é considerada uma variante um pouco modificada da poliamida. Uma das características mais importantes da aramida é a sua enorme resistência às altas temperaturas.

O kevlar e o nomex são os dois tipos mais conhecidos de aramida. A aramida veio para substituir o amianto - considerado cancerígeno - na confecção de roupas que exijam resistência a altas temperaturas. Pode-se constatar sua utilização em cortinas de cinemas e teatros, roupas aeroespaciais, roupas para bombeiros, para pilotos de corrida, entre outros (PALMA, 2003).

Figura 28: Malha de aramida (à dir.) e manta confeccionada com aramida (à esq.).
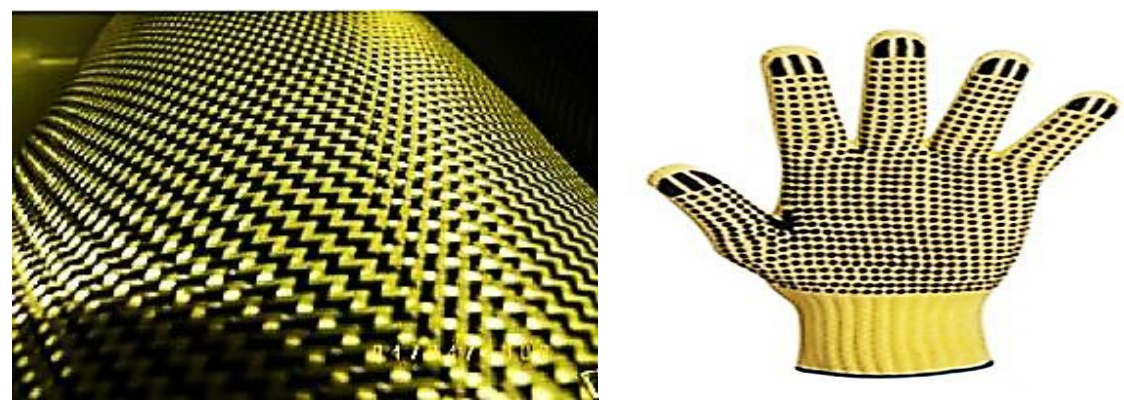
Fonte: <http://www.asalit.com.br/?page_id=654>, acesso em30 nov. 2013, às 14 h57. <http://www.solostocks.com.br/venda-produtos/insumos-seguranca-trabalho/outros-insumos-segurancatrabalho/luva-de-malha-aramida-kevlar-702959>, acesso em 30 nov. 2013, às 18 h57.

O polietileno é uma fibra sintética cuja superfície tem a capacidade de filtrar mais de 99\% das partículas maiores de 0,5 mícron, sendo uma excelente proteção contra a passagem de produtos químicos como chumbo, fibra de vidro ou amianto (PALMA, 2003).

Roupas feitas com esse material já são usadas por funcionários de usinas nucleares ou pessoas que manipulam produtos tóxicos em geral. Uma das fibras de polietileno mais conhecidas é o tyvek, usado na confecção de tecidos não tecidos.

Figura 29: Fibra de polietileno triturada (à dir.) e fibra de polietileno tubular (à esq.).

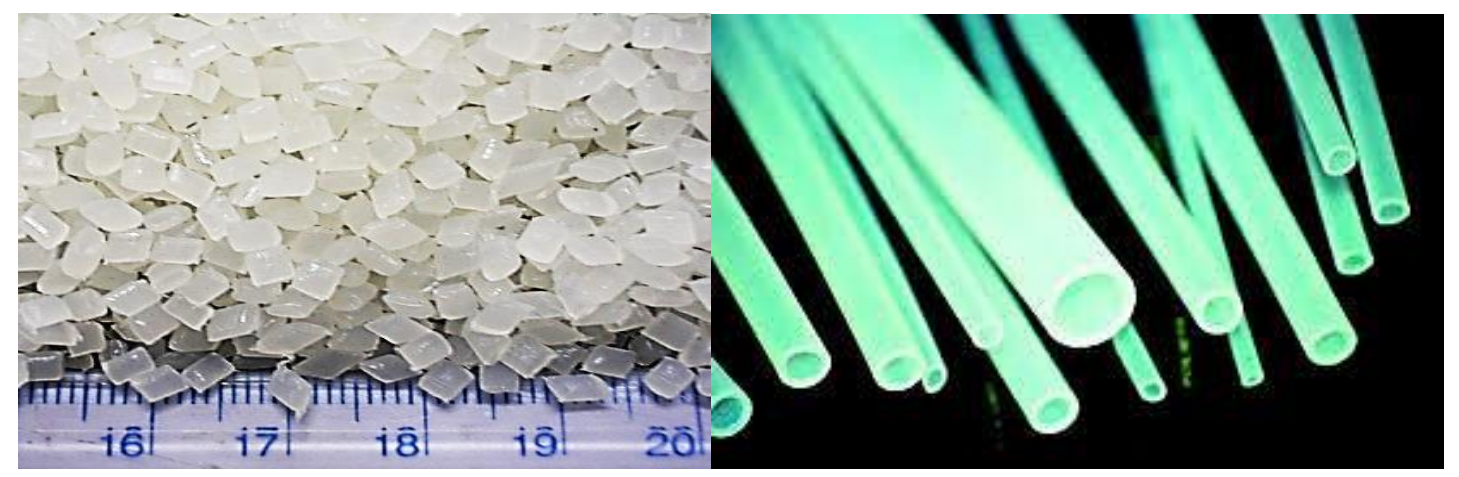

Fonte: <http://www.scielo.br/scielo.php?pid=S1517-70762006000400006\&script=sci_arttext>, acesso em 01 dez. 2013, às 12h38. <http://www.pavigreen.com/cesped-artificial-pavigreen-composicion-cesped-tipos-fibraspolietileno-nylon-polipropileno-nailon>, acesso em 30 nov. 2013, às $14 \mathrm{~h} 27$.

O poliuretano, ou spandex, é um termo genérico utilizado para descrever uma família de fibras químicas elastoméricas. O poliuretano apresenta propriedades elásticas que permitem o espichamento da fibra e seu retorno à forma natural.

Tecnicamente, essa fibra é uma longa cadeia de polímeros sintéticos formados por pelo menos $85 \%$ de uretano segmentado.

"Lycra" é a marca registrada de uma fibra de poliuretano comercializada pela empresa Du Pont do Brasil S/A.

Na compra de elásticos a serem usados na confecção de peças do vestuário, deve-se prestar bastante atenção na qualidade do material utilizado na sua fabricação. Deve-se sempre questionar o fornecedor se a matéria-prima utilizada foi elastano, pois elásticos confeccionados com borracha (elastoideno/elastodieno), embora mais baratos, tendem, com o passar do tempo, a secar e romper-se (PALMA, 2003).

Há outras fibras sintéticas que, apesar de possuírem qualidades ímpares, ainda não são 
utilizadas na confecção de roupas. É o caso do teflon, por exemplo. Esse hidrato de fluorcarbono é resistente ao calor, aos ácidos e à ruptura, podendo ser comparado a um metal nobre como a platina. Testes demonstram que o teflon é capaz de sustentar uma coluna d'água de até 80 metros de altura, sem vazamentos.

Figura 30: Espuma de poliuretano (à esq.) e travesseiro confeccionado com poliuretano (à dir.).

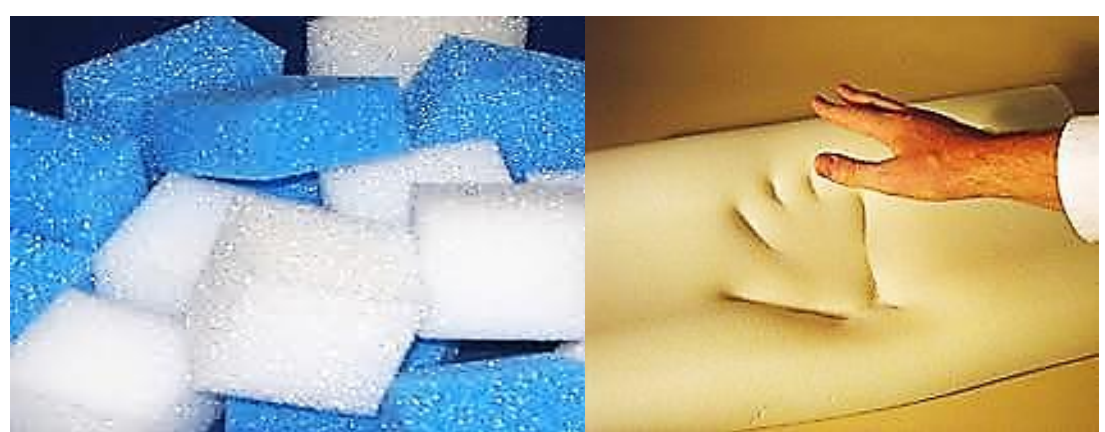

Fonte: <http://www.manutencaoesuprimentos.com.br/conteudo/4396-usos-da-espuma-de-poliuretano-naindustria/>, acesso em $02 \mathrm{dez}$. 2013, às 15h48. <http://portuguese.alibaba.com/product-gs/memory-foam-pillowcheap-decorative-pillows-memory-foam-contour-pillow-pillow-manufacturer-513313644.html>, acesso em 02 dez. 2013, às $12 \mathrm{~h} 37$. 


\section{MODA E SUSTENTABILIDADE}

\subsection{Conceito e Definição de Sustentabilidade}

Sustentabilidade é um conceito ambiental frequentemente usado de forma arbitrária. Muitas vezes, o termo é utilizado simplesmente como sinônimo de "durável", mas existem facetas e significados diversos por trás de uma única palavra.

Para Trigueiro (2003), o desenvolvimento sustentável tomou forma ao final dos anos 1980, após décadas de degradação socioambiental sem precedentes, e foi consagrado em 1992, na Rio-92. Mesmo assim, continua até hoje mal compreendido.

Sustentabilidade significa "sobrevivência", entendida como a perenidade dos empreendimentos humanos e do planeta (Trigueiro, 2003). Por isso, o desenvolvimento sustentável pressupõe o planejamento e a execução de ações - sejam elas governamentais ou empresariais, sejam elas locais, nacionais ou globais - que levem em conta, simultaneamente, as dimensões econômicas, ambientais e sociais de seus efeitos. Mercado + sociedade + recursos ambientais: esta somatória é a chave para a boa governança. Não é tarefa simples, pois exige radical mudança de mentalidade.

O setor empresarial moderno tem evoluído rapidamente nesse sentido, impulsionado em grande medida pelos desejos e tendências expressados dos consumidores, que cada vez mais recorrem aos valores da cidadania, como ética, justiça e transparência para tomarem suas decisões de compra.

As raízes da sustentabilidade estão na silvicultura. No início do século XVIII, a mineração de prata, base da economia da Saxônia, teve sua existência ameaçada devido a uma grande escassez de madeira. Florestas inteiras haviam sido devoradas pelas escavações para a exploração de minério e a utilização do carvão a lenha para fornos de fundição (TRIGUEIRO, 2003).

O inspetor-geral de mineração do estado da Saxônia, Hans Carls Von Carlowitz, criticou o pensamento da época, orientado ao lucro em curto prazo, argumentando que isso acabaria com o bem-estar. Exigiu, então, que a madeira fosse tratada de forma "cuidadosa", determinando que para cada quantidade de madeira cortada fosse plantado um número de árvores equivalente, e que assim as florestas pudessem voltar a crescer.

Para o mesmo autor, a partir desse conceito da silvicultura, segundo o qual deve-se garantir sempre um estoque de madeira para as gerações futuras, foi estabelecido o conceito 
da "sustentabilidade" ou do "sustainable development", o desenvolvimento sustentável.

Naquele tempo, assim como hoje, a ideia de sustentabilidade decorreu de uma crise. Tornou-se popular nos anos 1970 quando, pela primeira vez, também por meio do relatório do Clube de Roma, tornaram-se visíveis os "limites do crescimento".

\subsection{Definição de sustentabilidade pela Comissão de Brundtland}

O conceito de sustentabilidade alcançou reconhecimento internacional por conta do relatório da Comissão Mundial para o Meio Ambiente e Desenvolvimento das Nações Unidas - conhecida como Comissão Brundtland -, intitulado Nosso futuro comum, publicado em 1987. A comissão, presidida pela primeira-ministra da Noruega Gro Harlem Brundtland, desenvolveu a definição do conceito de sustentabilidade hoje universalmente aceita. De acordo com o conceito estabelecido, define-se o desenvolvimento sustentável como "aquele que atende às necessidades do presente sem comprometer as possibilidades de gerações futuras de atenderem às suas próprias necessidades" (ALVES, 1997). Trata-se basicamente da igualdade intergeracional.

A sustentabilidade exige que se deixe às futuras gerações uma herança que não seja essencialmente pior do que aquela que a geração atual herdou. Em outras palavras: deve-se viver de "dividendos" e deixar intacto o "capital".

Figura 31: Explicativo da Comissão Brundtland.

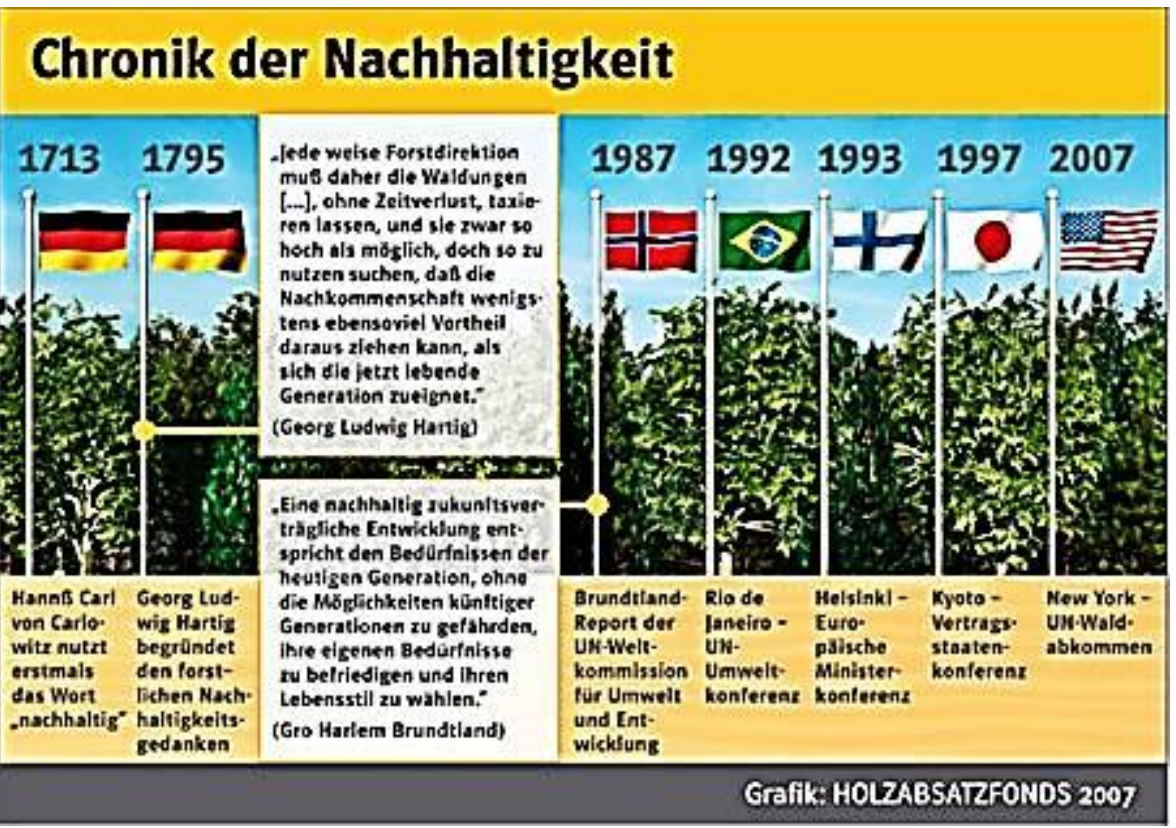

Fonte: <http://www.cidadaodomundo.org/2007/05/desde-a-rio-92-quase-nada-aconteceu/>, acesso em 05 dez. 2013, às $10 \mathrm{~h} 57$. 


\subsection{ECO-92 e o modelo da sustentabilidade de três pilares}

Em 1992, aconteceu no Rio de Janeiro a primeira Conferência das Nações Unidas sobre o Meio Ambiente e Desenvolvimento (UNCED). A conferência tratou especialmente da relação entre a determinação de metas ambientais e as políticas de desenvolvimento. Na conferência, da qual participaram cerca de 10 mil delegados, foi promulgada, além da Declaração Rio 92, a Agenda 21. A Agenda 21 é um programa de ação para o desenvolvimento sustentável global que tornou o conceito de sustentabilidade um princípio político formal.

Reconheceu-se, então, que a proteção ambiental global só é possível se forem considerados também aspectos econômicos e sociais.

A União Europeia formulou os três pilares da sustentabilidade na Conferência de Cúpula de Copenhague e no Tratado de Amsterdã de 1997. Esse princípio, denominado "Modelo de Sustentabilidade de Três Pilares", declara que a sustentabilidade não apenas abrange a herança da natureza que se transmitirá para as próximas gerações, mas também que ela deve incluir as realizações econômicas e as instituições sociais, como, por exemplo, a formação do desejo pela democracia ou pela solução pacífica de conflitos (ALVES, 1997).

Para o mesmo autor, o desenvolvimento sustentável, portanto, fundamenta-se em cada um dos pilares - o ecológico, o econômico e o social. Se um dos três pilares se rompe, a "construção da sustentabilidade" desmorona.

\subsection{O elo entre os três pilares da sustentabilidade}

A resposta à questão "Quando ocorrerá um desenvolvimento sustentável positivo?" permanece incerta. Para que isso aconteça, é necessário que todas as três áreas da sustentabilidade apresentem um desenvolvimento positivo, ou basta que somente um dos pilares se desenvolva de forma positiva? Especialmente controversa é a relação entre os três pilares fundamentais da sustentabilidade. É permitido, por exemplo, que as três áreas de sustentabilidade substituam-se mutuamente. Poderia, assim, um alto nível de crescimento econômico compensar a degradação do meio ambiente?

Caso se permitisse uma compensação entre os três pilares, se falaria então de uma "frágil" sustentabilidade; em caso negativo, de uma "forte" sustentabilidade. 
Em razão das constantes ameaças sobre o ambiente e a ampla escassez de recursos naturais, ocorre a ampliação da importância da sustentabilidade e o modo de enxergá-la como fundamento da sustentabilidade, não apenas como um pilar equivalente aos outros. Somente quando as funções ambientais básicas são asseguradas é possível realizar-se um desenvolvimento econômico e social (ALVES, 1997).

\subsection{Desenvolvimento, meio ambiente e práticas educativas}

A reflexão sobre as práticas sociais, em um contexto marcado pela degradação permanente do meio ambiente e do seu ecossistema, envolve uma necessária articulação com a produção de sentidos sobre a educação ambiental.

Segundo Alves, a dimensão ambiental configura-se crescentemente como uma questão que envolve um conjunto de fatores do universo educativo, o que potencializa o engajamento dos diversos sistemas de conhecimento, a capacitação de profissionais e a participação da comunidade universitária em uma perspectiva interdisciplinar.

Nesse sentido, a produção de conhecimento deve necessariamente contemplar as interrelações do meio natural com o social, incluindo a análise dos determinantes do processo, o papel dos diversos atores envolvidos e as formas de organização social que aumentam o poder das ações alternativas de um novo desenvolvimento sob uma perspectiva que priorize um novo perfil desse desenvolvimento, com ênfase na sustentabilidade socioambiental (ALVES, 1997).

Tomando-se como referência o fato de a maior parte da população brasileira viver em cidades, observa-se uma crescente degradação das condições de vida, que se reflete em uma crise ambiental. Isso remete a uma necessária reflexão sobre os desafios para que se alterem as formas de pensar e agir em torno da questão ambiental sob uma perspectiva contemporânea. Leff (2001) fala sobre a impossibilidade de resolver os crescentes e complexos problemas ambientais e reverter suas causas sem que ocorra uma mudança radical nos sistemas de conhecimento, valores e dos comportamentos gerados pela dinâmica de racionalidade existente, fundamentada no aspecto econômico do desenvolvimento.

A partir da Conferência Intergovernamental sobre Educação Ambiental realizada em Tbilisi, capital da Geórgia (então parte da União Soviética), em 1977, inicia-se um amplo processo em nível global, orientado para a criação de condições que formassem uma nova consciência sobre o valor da natureza e para a reorientação da produção de conhecimento 
baseada nos métodos da interdisciplinaridade e nos princípios da complexidade. Esse campo educativo tem sido fertilizado transversalmente e isso tem possibilitado a realização de experiências concretas de educação ambiental de forma criativa e inovadora por diversos segmentos da população e em diversos níveis de formação.

O documento da Conferência Internacional sobre Meio Ambiente e Sociedade, Educação e Consciência Pública para a Sustentabilidade, realizada em Tessalônica (Grécia), chama a atenção para a necessidade de se articularem ações de educação ambiental baseadas nos conceitos de ética, sustentabilidade, identidade cultural, diversidade, mobilização e participação e práticas interdisciplinares. (SORRENTINO, 1998).

A necessidade de abordar o tema da complexidade ambiental decorre da percepção sobre o incipiente processo de reflexão acerca das práticas existentes e das múltiplas possibilidades de, ao se pensar a realidade de modo complexo, defini-la como uma nova racionalidade e um espaço onde se articulam natureza, técnica e cultura.

Segundo o mesmo autor, refletir sobre a complexidade ambiental abre uma estimulante oportunidade para compreender a gestação de novos fatores sociais, que se mobilizam para a apropriação da natureza, para fomentar um processo educativo articulado e compromissado com a sustentabilidade e a participação, apoiado em uma lógica que privilegia o diálogo e a interdependência de diferentes áreas do saber. Mas também questiona valores e premissas que norteiam as práticas sociais prevalecentes implicando mudança na forma de pensar e transformar o conhecimento e as práticas educativas.

A realidade atual exige uma reflexão cada vez menos linear e isso se produz na interrelação dos saberes e das práticas coletivas que criam identidades, valores comuns e ações solidárias diante da reapropriação da natureza, sob uma perspectiva que privilegia o diálogo entre saberes.

A preocupação com o desenvolvimento sustentável representa a possibilidade de garantir mudanças sociopolíticas que não comprometam os sistemas ecológicos e sociais que sustentam as comunidades.

A complexidade desse processo de transformação de um planeta não apenas crescentemente ameaçado, mas também diretamente afetado pelos riscos socioambientais e seus danos, é cada vez mais notória. A concepção "sociedade de risco" de Beck (1992) amplia a concepção de um cenário marcado por nova lógica de distribuição dos riscos.

Os grandes acidentes envolvendo usinas nucleares e contaminações tóxicas de grandes proporções, como os casos de Three Mile Island (1979) e Love Canal (1978), ambos nos 
Estados Unidos, de Bhopal (1984), na Índia, e de Chernobyl (1986), na Ucrânia (então parte da União Soviética), estimularam o debate público e científico sobre a questão dos riscos nas sociedades contemporâneas. Inicia-se uma mudança de escala na análise dos problemas ambientais, que se tornaram mais frequentes e que, pela sua própria natureza, tornam-se mais difíceis de serem previstos e assimilados como parte da realidade global.

Ulrich Beck identifica a sociedade de risco com uma segunda modernidade, ou modernidade reflexiva, que emerge com a globalização, a individualização, a revolução de gênero, o subemprego e a difusão dos riscos globais. Os riscos atuais caracterizam-se por trazerem consequências, em geral de alta gravidade, desconhecidas a longo prazo e que não podem ser avaliadas com precisão, como é o caso dos riscos ecológicos, químicos, nucleares e genéticos.

O tema da sustentabilidade confronta-se com o paradigma da sociedade de risco. Isso implica a necessidade de se multiplicarem as práticas sociais baseadas no fortalecimento do direito ao acesso à informação e à educação ambiental em uma perspectiva integradora. Além disso, demanda aumentar o poder das iniciativas baseadas na premissa de que um maior acesso à informação e mais transparência na administração dos problemas ambientais urbanos podem implicar na reorganização do poder e da autoridade.

Existe, portanto, a necessidade de que sejam incrementados os meios de informação e o acesso a eles, bem como o papel indutivo do poder público nos conteúdos educacionais, como caminhos possíveis para se alterar o quadro atual de degradação socioambiental.

Trata-se de promover o crescimento da consciência ambiental expandindo a possibilidade de a população participar em um nível mais alto no processo decisório, como uma forma de fortalecer sua corresponsabilidade na fiscalização e no controle dos agentes de degradação ambiental.

Há uma demanda atual de que a sociedade esteja mais motivada e mobilizada para assumir um papel mais propositivo, bem como de que seja capaz de questionar de forma correta a falta de iniciativa do governo na implementação de políticas ditadas pelo binômio da sustentabilidade e do desenvolvimento no contexto de crescente dificuldade de promoção da inclusão social.

Nessa direção, a problemática ambiental constitui um tema muito propício para que aprofundemos a reflexão e a prática em torno dos restritos impactos das práticas de resistência e de expressão das demandas da população das áreas mais afetadas pelos constantes e crescentes agravos ambientais. Representa também a possibilidade de abertura de 
estimulantes espaços para a implementação de alternativas diversificadas de democracia participativa, notadamente a garantia do acesso à informação e à consolidação de canais abertos para uma participação plural.

A postura de dependência e de desresponsabilização da população decorre principalmente da desinformação, da falta de consciência ambiental e de um déficit de práticas comunitárias baseadas na participação e no envolvimento dos cidadãos que proponham uma nova cultura de direitos, baseada, por sua vez, na motivação e na coparticipação da gestão ambiental (TRIGUEIRO, 2003).

\subsection{Moda aliada à sustentabilidade}

Segundo Costa e Ignácio (2015), entende-se como desenvolvimento sustentável um modelo econômico, político, social, cultural e ambiental equilibrado, que satisfaça as necessidades da geração atual sem comprometer as gerações futuras.

Essa concepção começa a se formar e a se difundir concomitantemente ao questionamento de estilo de desenvolvimento adotado, quando se constatado que este é ecologicamente predatório na utilização de recursos naturais, socialmente perverso, com geração de pobreza e extrema desigualdade social, politicamente injusto, com concentração e abuso de poder, culturalmente alienado em relação aos seus próprios valores e eticamente censurável no que diz respeito aos direitos humanos e aos das demais espécies.

Para o mesmo autor (COSTA e IGNÁCIO, 2015), o conceito de sustentabilidade comporta sete aspectos ou dimensões principais, a saber: sustentabilidade social, sustentabilidade econômica, sustentabilidade ecológica, sustentabilidade cultural, sustentabilidade espacial, sustentabilidade política e sustentabilidade ambiental.

Para que seja possível tratar as questões relacionadas à sustentabilidade, como citado no ano de 2002, é necessária a integração de três dimensões do desenvolvimento sustentável: econômica, social e ambiental.

Na dimensão social, é possível analisar o capital humano de um empreendimento, comunidade, sociedade como um todo. Além de salários justos e adequação à legislação trabalhista, é preciso pensar em outros aspectos, como o bem-estar dos funcionários da empresa, propiciando-se um ambiente de trabalho agradável, e priorizando-se a saúde do trabalhador e da sua família. Além disso, é imprescindível verificar como a atividade econômica afeta as comunidades localizadas ao redor da empresa (COSTA e IGNÁCIO, 
2015).

$\mathrm{Na}$ dimensão ambiental, pode-se citar a análise do capital natural de um empreendimento ou sociedade. É importante que haja conscientização e pensamento de pequeno, médio e longo prazo. A princípio, praticamente toda atividade econômica tem impacto ambiental negativo. Nesse aspecto, a empresa ou a sociedade deve pensar nas formas de amenizar esses impactos e compensar o que não for possível amenizar. Por exemplo, uma empresa que usa determinada matéria-prima deve planejar formas de repor ou diminuir o máximo possível o uso desse material, assim como saber medir a quantidade de carbono utilizada ao longo do processo produtivo e a quantidade de $\mathrm{CO}_{2}$ emitido pelas suas ações. Além disso, é preciso levar em conta a adequação à legislação ambiental e a vários princípios discutidos atualmente, como o Protocolo de Kyoto. Para uma determinada região geográfica, o conceito é o mesmo e pode ser adequado, por exemplo, com um sério zoneamento econômico da região.

Na dimensão econômica, é possível analisar a correlação da palavra economia com organização. Com o passar dos anos, ou mesmo séculos, a palavra economia foi direcionada apenas à vertente dos negócios ou ao sentido da poupança, de economizar. Este pilar traz o retorno do significado de cuidar da casa, afincado pelos gregos na Antiguidade. São analisados temas ligados à produção, distribuição e consumo de bens e serviços, e é preciso levar em conta os outros dois aspectos. Não é inteligente lucrar devastando, por exemplo.

De acordo com Bacha, Santos e Schaun (2010), o tema sustentabilidade tem apresentado crescente interesse entre pesquisadores acadêmicos. A importância relacionada ao assunto se deve principalmente à atenção despertada face às mudanças climáticas causadas pela ação predatória do homem no meio ambiente, que causa uma emergência planetária. Segundo Gore (2006), se reconhece o preço de fatores como o meio ambiente, o impacto sobre as comunidades e a longevidade dos funcionários, o que pode significar uma visão mais ampla de sustentar a lucratividade da empresa ao longo do tempo.

De acordo com Lacy (Diretor executivo da Accenture Sustainability Services para Europa, África, Oriente Médio e América Latina, 2010), foi lançado em Nova York o maior estudo de sustentabilidade corporativa, publicado pela United Nations Global Compact e pela Accenture Sustainability Services.

O estudo teve como objetivo entrevistar cerca de 1.000 funcionários e líderes empresariais. O levantamento indica que o compromisso com as questões ambientais, sociais e de governança tornou-se significativo. 
Os dados relacionados à pesquisa são:

- 93\% dos CEOs enxergam a sustentabilidade como fundamental para o sucesso da sua empresa, mostrando recente mudança na mentalidade desde a última pesquisa, realizada em 2007;

- A credibilidade da nova era da sustentabilidade está entrando em vigor, e $80 \%$ dos entrevistados preveem um "ponto de inflexão" dentro de 15 anos - um momento em que a sustentabilidade será totalmente incorporada às estratégias de negócio da maioria das empresas em nível global;

- A credibilidade associada ao fato de que, no início da época em que a sustentabilidade estará completamente integrada aos negócios haverá necessidade de vivenciar um ambiente operacional diferente do atual;

- Há necessidade de um enfoque mais amplo sobre a criação de valor empresarial e social, que será caracterizada pela mudança de foco exclusivamente no lucro financeiro para uma compreensão de longo prazo sobre a criação de valor que considere tanto os impactos positivos quanto os negativos de uma empresa sobre a sociedade e o meio ambiente;

- Os negócios devem afastar-se cada vez mais da visão da operação como uma parte distinta da cadeia de valor para assumirem maior responsabilidade em um sistema completo de insumos;

- Necessidade de novas formas de colaboração e parcerias com fornecedores e distribuidores, organizações da sociedade civil e governos para impulsionar os resultados da sustentabilidade;

- Uso mais eficaz da tecnologia para impulsionar a transparência, a eficiência dos recursos e uma transição para a infraestrutura de energia limpa;

- Melhoria na eficiência das práticas comerciais em mercados emergentes para atender às necessidades de consumidores e cidadãos diferentes e canais alternativos de distribuição;

- Liderança e Cultura Sustentáveis, que incorporam as questões de sustentabilidade na maneira como os executivos e os funcionários pensam sobre estratégia e execução, nova geração de líderes de negócios com mais ousada e com posição mais proativa no cenário mundial - uma forma de liderança que vai além das fronteiras tradicionais e articula uma visão para o futuro sustentável da indústria e da sociedade em geral.

Segundo Sgarbi et al (2008), os estudos sobre a sustentabilidade têm apresentado um crescente interesse na comunidade acadêmica, despertando não só o interesse dos estudiosos 
da área socioambiental, mas também dos pesquisadores de temas como estratégia, competição, gestão, moda, política, dentre outros.

De acordo com Moura (2002), as diversas definições, enfoques e visões de sustentabilidade apresentam contradições e ambiguidades, às vezes irreconciliáveis, principalmente no que se refere à questão do desenvolvimento sustentável. A semântica da palavra é empregada no sentido de progresso e há tensão entre crescimento econômico ilimitado e a finitude dos recursos ambientais. Existem duas correntes com enfoques distintos, a eco tecnocrática, ou economia verde, e a ecos social e pessimista.

Lang (2009) diz que o termo sustentabilidade constitui assunto de debates acirrados nos meios acadêmico, empresarial e governamental, tanto no Brasil como nas demais nações do mundo, em vista de as questões socioambientais se tornarem cobradas principalmente daqueles que se utilizam dos recursos naturais e do meio social para permanecerem e se perpetuarem em mercado competitivos.

De acordo com Santos (apud Sgarbi et al, 2008), os primeiros estudos teóricos sobre a sustentabilidade iniciaram-se no campo das ciências ambientais e ecológicas, trazendo à discussão contribuições de diferentes disciplinas, tais como Economia, Sociologia, Filosofia, Política, Direito e Moda. No entanto, a questão da sustentabilidade ambiental passou a ocupar lugar de importância no debate acadêmico e político, sobretudo a partir do final dos anos 1960, porém, as duas últimas décadas testemunharam a emergência do discurso da sustentabilidade como expressão dominante no debate que envolve as questões de meio ambiente e de desenvolvimento social em sentido amplo.

Diniz da Silva (2009) explica que o termo se transformou em cenário para causas sociais e ambientais, principalmente nos negócios, em que prevalece a ideia de que geração de lucro para os acionistas protege o meio ambiente e melhora a qualidade de vida das pessoas com que interagimos.

Sustentabilidade seria fruto de um movimento histórico recente que passa a questionar a sociedade industrial enquanto modo de desenvolvimento. Trata-se conceito síntese dessa sociedade, cujo modelo se mostra esgotado. A sustentabilidade pode ser considerada um conceito importado da ecologia, mas sua operacionalidade ainda precisa ser provada nas sociedades humanas (ROSA, 2007).

O termo sustentabilidade remete ao vocábulo "sustentar", no qual a dimensão longo prazo se encontra incorporada. Há necessidade de encontrar mecanismos de interação nas sociedades humanas que ocorram em relação harmoniosa com a natureza. "Numa sociedade 
sustentável, o progresso é medido pela qualidade de vida (saúde, longevidade, maturidade psicológica, educação, ambiente limpo, espírito comunitário e lazer criativo) ao invés de puro consumo material" (FERREIRA, 2005). Para Schweigert (2007), o termo deriva do comportamento prudente de um predador ao explorar sua presa, ou seja, moderação, por tempo indeterminado. Isto é, o ser humano necessitaria conhecer as particularidades do planeta para utilizá-lo por longo tempo assegurando a continuidade da própria espécie.

Sustentabilidade é consequência de um complexo padrão de organização que apresenta cinco características básicas: interdependência, reciclagem, parceria, flexibilidade e diversidade. Se estas características forem aplicadas às sociedades humanas, elas também poderão alcançar a sustentabilidade (CAPRA, 2006 apud ROSA, 2007).

A sustentabilidade, para Netto (2010), é um fenômeno contemporâneo que se alinha aos anseios da sociedade: crescer e desenvolver-se sem comprometer o futuro do planeta. Porém, para algumas correntes de pensadores da área da economia, há uma contradição nisso, já que não há possibilidade de crescimento sem que haja também impactos socioambientais.

Entender a importância da relação moda/consumo/sustentabilidade nos dias atuais é descobrir novas formas de fazer diferente e, ao mesmo tempo, respeitar o indivíduo, a sociedade e o meio ambiente. Isso tudo sem que se deixe de lado a responsabilidade econômica que compete a essa relação tão complexa.

A moda é um acontecimento em constante evolução e que funciona como um sistema ou organismo, o qual possui características mutantes e mutáveis. Solomon (2002) também compartilha a ideia de que a moda faz parte de um sistema maior, que vai muito além da roupa. Consiste em pessoas e organizações envolvidas na criação de significados simbólicos e sua transferência para os produtos culturais, afetando não só o vestuário, mas todos os tipos de fenômenos culturais, incluindo música, arte, arquitetura e design (SANTAELLA, 2009).

De acordo com Souza (1987), a moda surgiu no século XV, na Idade Moderna. Tratase de um fenômeno recente e moderno, iniciado com o crescimento e o desenvolvimento das cidades e a organização da vida nas cortes, quando a burguesia - que não era nobre, mas era rica - começou a imitar as roupas dos nobres. Portanto, a moda surge somente a partir do momento em que a vestimenta começa a ser imitada, sabendo-se que o que é usado como vestuário, desde muito tempo, é percebido pelas classes sociais como uma forma de identificação, diferenciação e expressão.

Sendo assim, tais características do vestuário são detentoras de poder, logo a moda e a indumentária fazem parte do mecanismo político de uma sociedade. 
Segundo Gobé apud Solomon (2000), em tempos primevos, o homem precisava se agasalhar com peles para se proteger do clima; com o tempo, o que era apenas agasalho transformou-se em objeto de poder e status, de diferenciação e de expressão. Percebe-se que, desde os primórdios, a vestimenta - não a moda - já era utilizada também como um fator subjetivo. Vestir-se, para os ancestrais, correspondia à necessidade de proteção contra elementos da natureza, porém, nos dias atuais, isso é mais do que simples proteção. Escolher vestir-se com cores e formas específicas representa a necessidade de se integrar aos costumes locais e de ser aceito por determinado grupo.

Para que o ator represente um papel de modo convincente, precisará dos acessórios e da ambientação correta. Os consumidores aprendem que diferentes papéis são acompanhados de constelações de produtos e atividades que ajudam a definir esses papéis. Alguns "acessórios" são tão importantes para os papéis que representamos que podem ser vistos como uma parte da extensão do eu. (SOLOMON, 2002, p.118)

De acordo com Barnard (1996), ao usar determinada vestimenta, o indivíduo tenta mostrar ao outro o que é, ou imagina ser, ao ponto de tentar fazê-lo aceitar aquilo como verdade. Pode-se inferir que, na moda, os objetos utilizados para compor um visual dizem muito sobre o indivíduo (LIPOVETSKY, 2009).

Segundo Cidreira (2007), o termo moda surgiu do latim modus, que significa maneira, modo individual de fazer, ou uso passageiro que regula a forma dos objetos materiais, por exemplo, as roupas. Mais genericamente, diz respeito ao modo de viver e de se vestir.

A língua inglesa recupera a palavra francesa façon (modo) e a transforma em "fashion". Sendo assim, é notável a presença da palavra "modo" no sentido de moda significando forma particular, sistema, habilidade e, em alguns casos, processo de aculturação.

É a moda que exibe, por meio de signos mutantes, a corporificação, a externalização performática de subjetividades fragmentadas, sem contornos fixos, movediças, escorregadias, mutáveis, flutuantes, voláteis. Em razão disso, a moda se constitui em um laboratório privilegiado para o exame das subjetividades em trânsito. (SANTAELLA, 2009, p. 99)

De acordo com as palavras de Barnard (2003), a moda é uma forma de se comunicar com o outro por meio do que se veste. É utilizada como uma via de expressão e identificação. "A moda e a indumentária são formas de comunicação não verbais, uma vez que não usam palavras faladas ou escritas" (BARNARD, 2003, p. 51).

Por meio da moda, o indivíduo tenta expressar o que é - ou imagina que seja -, e 
assim espera ser identificado pelo outro. É uma comunicação por meio de símbolos. A comunicação deve ser compreendida e utilizada para transmitir mensagens, caso contrário, ela passa a ser somente uma peça de vestuário, uma proteção para o corpo (LIPOVETSKY, 2009).

Além de ser vista como signo, a moda também é considerada um fenômeno cultural, que mobiliza todo o universo. Barnard também concorda com a relação moda/signo quando afirma que o fenômeno da moda é "carregado de significados simbólicos e míticos" (BARNARD apud WILSON, 1985, p. 10).

Sendo assim, a moda se apresenta como um fenômeno efêmero, temporal, cultural, antropológico, contextual e conceitual, isto é, trata-se de um fenômeno complexo, como analisa Lipovetsky:

Pensar a moda requer não apenas que se renuncie a assimilá-la a um princípio inscrito necessária e universalmente no curso do desenvolvimento de todas as civilizações, mas também que se renuncie a fazer dela uma constante histórica fundada em raízes antropológicas universais. (LIPOVETSKY, 1989, p. 23)

\subsection{Consumo, capitalismo e moda}

Segundo Chandler (1998), o período entre 1850 e 1920 é aquele em que se formou o capitalismo moderno. De acordo com Weber (2011), o capitalismo se baseia na possibilidade de troca com expectativa de lucro, ou seja, é a oportunidade que o indivíduo tem de adquirir um pouco mais daquilo que é necessário à sua subsistência por meio do que recebeu pelo seu trabalho.

A partir do capitalismo moderno, tornou-se notório o crescimento do consumo. Os grandes avanços tecnológicos, a expansão dos meios de comunicação, a entrada da mulher no mercado de trabalho, entre outros acontecimentos, colaboraram para que os produtos passassem a ser produzidos mais rapidamente, barateando-se o seu preço e estimulando-se o seu consumo (CHANDLER, 1998).

Entretanto, nos dias de hoje, muito do que é consumido não o é por conta de características funcionais, e sim por representar poder, status e ostentação. É como se o objeto tivesse o poder da sedução. É o caso de se questionar se é mesmo necessário trocar de sapatos, roupas, bolsas ou acessórios em períodos cada vez mais curtos. O certo é que a moda, além de efêmera, é abusiva. E o consumismo exacerbado, comum às práticas capitalistas, tomou uma dimensão ostentatória, perdulária, excessiva e abusiva. Consome-se por brincadeira, por jogos 
de manipulações, encenações e fantasias.

Para entender a dinâmica da sociedade de consumo de produtos de moda, ou seja, produtos mais desejados do que necessários, pode-se tomar como base a filosofia de Baudrillard. O filósofo analisa o conceito real de gadget ao mesmo tempo em que percebe a importância que ele tem na vida do indivíduo pós-moderno:

Por trás de cada objeto real há o objeto sonhado. Na moda, também é assim que funciona. (BAUDRILLARD, 1981, p. 126)

Kotler (1998, p. 97), em sua análise mercadológica, vai ao encontro das ideias de Baudrillard ao afirmar que "não consumimos produtos, consumimos a imagem que temos deles". O que importa é o que se percebe.

Então, sendo a percepção tão importante, pode-se pensar nela como algo capaz de destruir o paradigma de que a moda sustentável não pode ser um negócio lucrativo. É preciso ir além dos esforços culturais, sociais, ambientais, políticos e econômicos. Para se chegar ao intelecto do consumidor e promover a mudança de padrão de pensamento, é necessário esforço mercadológico, isto é, utilizar as ferramentas do marketing. Infere-se que tudo dependerá da forma como isso será trabalhado na mente do consumidor.

Marketing não é uma batalha de produtos. O marketing é uma batalha de percepções. (RIES e TROUT, 1993, p. 11)

Pode-se pensar que os fatores que levam o consumidor a decidir pela compra de um produto relativo à moda estão muito mais alinhados às questões emocionais do que às racionais. Se ações de marketing podem fazer com que o indivíduo perceba a moda como beleza, poder, status, por que não fazê-lo perceber as ações de sustentabilidade como um valor agregado, um atributo positivo na adoção de uma marca? (COBRA, 2007).

Ocorre que, na moda, a cada estação do ano introduz-se uma nova coleção, depois outra, e isso infinitamente. Então, alinhar sustentabilidade, eficiência e crescimento acelerado do consumo de moda pode parecer uma tarefa impossível.

Porém, se consideramos que produção sustentável é também produzir de forma criativa - o que impõe novas formas de reutilizar, reciclar, recriar e renovar -, é razoável considerar que pesquisas de estilo e o desenvolvimento do design podem colaborar com esse processo. "Talvez seja uma mudança de paradigma em que todos ganham, isto é, a moda, a 
sociedade e o meio ambiente. A roupa é uma parte muito significativa do que consumimos e as pessoas estão percebendo que a forma como consumimos decide o futuro do planeta" (HAMNETT, 2009 apud LEE, 2009, p. 8).

Os impactos que o consumidor pode gerar - positivos ou negativos - acontecem em dois momentos: antes da compra e depois que o consumo já ocorreu. Ao comprar produtos de empresas que tenham responsabilidade social, o consumidor ajuda a ampliar e manter a lógica do comércio justo. Por outro lado, um consumidor que desconsidera o compromisso social do fornecedor ajuda a manter um processo de expansão insustentável ou agressivo à sustentabilidade.

Ao tomar sua decisão de compra, o consumidor deve verificar de onde veio o produto e a quem sua compra vai beneficiar: se é algo que ajuda a sociedade e o meio ambiente ou se é algo que prejudica (BELINK, 2007).

\subsubsection{Comportamento do consumidor}

Subentende-se que, para atender um novo consumidor mais consciente e responsável, deve-se esperar um novo comportamento de consumo, ou seja, um comportamento que respeite as novas regras, além de se poder contribuir para sua propagação. Isto é o que se pretende: tentar entender o comportamento do consumidor contemporâneo, ou seja, o comportamento do indivíduo pós-moderno em relação ao consumo.

A esse respeito, Kotler (2000, p. 33) afirma que “[...] os profissionais de marketing, paralelamente a outras influências da sociedade, influenciam desejos [...]".

O mesmo autor afirma que, desde pequenos, os indivíduos têm desejos e, de alguma maneira, tentam satisfazê-los. As crianças têm necessidade de se alimentar e de aconchego, e procuram o "colo" de suas mães para superar isso. Ao lado do desejo caminha a frustração e novamente o desejo, formando-se um ciclo que acompanha o indivíduo por toda a vida.

Maslow (2000) preconiza que há uma hierarquia de necessidades humanas dividida em necessidades primárias e secundárias e estabelecida em três níveis: baixo, intermediário e alto. Já Woodruff e Gardial (1996) afirmam existir também uma hierarquia de valor dividida em atributos concretos, atributos abstratos, consequências funcionais e psicológicas. Ou seja, em determinados momentos, as pessoas são motivadas por necessidades específicas. Se o hábito de consumir também é norteado pelas necessidades básicas ou fisiológicas, como respiração, comida, água, sexo, segurança, proteção, que são atributos concretos e que se 
encontram nos níveis mais baixos e intermediários, compreende-se que elas devem ser satisfeitas antes de se chegar aos níveis mais altos - autoestima, autor realização, confiança. Isto é, para atingir a autor realização, que se trata de uma consequência psicológica, é necessário atingir o topo da hierarquia.

O comportamento do consumidor é definido como as atividades físicas e mentais realizadas por clientes de bens de consumo e industriais que resultam em decisões e ações, como comprar e utilizar serviços, bem como pagar por eles. (SHETH; MITTHAL; NEWMAN, 2001, p. 29)

\subsubsection{Moda, consumo e práticas socioambientais}

De acordo com Duarte (2012), "a moda que não polui o planeta" e que está comprometida com valores sociais pode ser conhecida por uma nomenclatura específica, sendo que cada denominação possui características próprias e processos particulares. Nesse contexto, os novos conceitos do consumo de moda são conhecidos como responsável, ecológico ou verde, sustentável, solidário, consciente e ético.

QUADRO 4 - Conceitos da relação moda-consumo-sustentabilidade

Consumo

Responsável
- $\quad$ Significa consumir melhor, com mais qualidade e de maneira mais responsável com a natureza, observando-se atentamente as grandes instituições, as posturas individuais, a qualidade de vida e a preservação ambiental;

- Recusa o consumismo sem consciência, consequência do individualismo que é peculiar ao consumo contemporâneo;

- $\quad$ É corresponsável pelo cuidado do mundo, a partir da ótica do consumo individual: é possível escolher o consumo dos materiais que são menos prejudiciais.

\footnotetext{
Consumo Ecológico - Abrange questões mais amplas do que simplesmente a ou Verde não agressão ao meio ambiente e defende um monitoramento da postura das empresas, tendo como objetivo o comércio ético dentro do atual sistema econômico;
}

- $\quad$ Consumo que opta por produtos éticos, que recusa a 
identificação com as marcas e questiona o impacto ambiental dos produtos e serviços.

Consumo

Sustentável
- $\quad$ É uma proposta mais ampla, pois envolve mudança de atitude, adotando novas formas e estilos de consumo que considerem os recursos naturais para satisfazer as necessidades atuais, sem comprometer as gerações futuras;

- $\quad$ Fixa-se em um padrão de consumo diferente para todos os níveis de renda, em todas as economias do planeta;

- $\quad$ Enfatiza ações coletivas e mudanças políticas, econômicas e institucionais, em detrimento de ações individuais, para fazer com que os padrões e os níveis de consumo se tornem mais sustentáveis;

- $\quad$ Tem como propósitos garantir que as necessidades da sociedade sejam atingidas, evitar o consumo perdulário e contribuir para a proteção do meio ambiente;

- Insere as discussões de consumo e meio ambiente na esfera pública, que, por definição, é o espaço da política.
Consumo Solidário fornecedores;

- $\quad$ Almeja o bem-estar pessoal no consumo e promove a qualidade de vida dos trabalhadores que elaboram, distribuem e comercializam os produtos e serviços, o que mantém o equilíbrio dos ecossistemas e contribui para a construção de uma sociedade mais justa e solidária.

Consumo

- $\mathrm{O}$ indivíduo concebe $\mathrm{o}$ ato de consumo como fio Consciente condutor de ações mais justas e solidárias com a sociedade, defende a possibilidade de contribuir para mudanças por meio do ato de consumo, ao reconhecer e valorizar a relação do 
indivíduo com o coletivo e com as gerações futuras;

- As opções do indivíduo consciente incluiriam a reavaliação da quantidade de produtos adquiridos, a avaliação das marcas que irá consumir devido à sua responsabilidade social, a redução do desperdício de água e energia e reaproveitamento e reciclagem do que antes era descartado;

- Fundamenta-se no ato de consumir produtos que possuam real utilidade e dos quais se tenha verdadeira necessidade. Além disso, seria uma contribuição voluntária, cotidiana e solidária para garantir a melhoria das condições socioambientais;

- $\quad$ O consumo consciente seria um primeiro passo para alcançar a sustentabilidade, na medida em que, no plano individual, o consumidor pode adotar atitudes conscientes e mudar sua postura no consumo. "O consumo consciente não é necessariamente sustentável, embora todo consumo sustentável seja consciente. A questão da sustentabilidade é uma oitava maior do consumo consciente" (FELDMANN apud CRESPO, 2003, p. 55);

- O consumo consciente poderia incentivar o excesso de consumo, na medida em que legitimaria quantidades elevadas de consumo realizadas de forma consciente. Outra crítica se refere ao fato de não tratar com maior precisão da equalização das desigualdades entre aqueles que produzem e aqueles que consomem o que foi produzido, o que geraria um distanciamento, portanto, um problema de acesso, distribuição e justiça.

- $\quad$ Abrange questões mais amplas que simplesmente a não agressão ao meio ambiente e defende um monitoramento da postura das empresas, com o objetivo de um comércio ético dentro do atual sistema econômico; 
- Consumo que opta por produtos éticos, que recusa a identificação com as marcas e questiona o impacto ambiental dos produtos e serviços.

Adaptado de VIEGAS, 2010. 


\section{COURO}

\subsection{Definição de couro}

Conforme definição da Associação Brasileira de Normas Técnicas (ABNT), o couro é um material extraído exclusivamente da pele animal, curtida por qualquer processo, e constituído essencialmente de derme.

O couro constitui a pele do animal preservada da putrefação e apresenta uma textura extremamente rica de fibras colágenas, que deverão passar pelos diferentes estágios de transformação para se tornarem flexíveis e macias. O couro pode ser definido como um subproduto animal que, após sofrer o processo de curtimento, não é mais passível de sofrer o ataque de micro-organismos decompositores.

Em estado natural, o couro representa muito mais do que a pura e simples cobertura externa de um animal. Constitui seu registro histórico: pelos, defeitos que ali estão gravados, riscos, arranhões e cicatrizes e a própria matéria-prima da indústria do couro.

Ainda de acordo com a orientação da ABNT, por ser um produto natural, a palavra “couro" está protegida pela Lei 4.888/1965, que proíbe o seu emprego para denominar produtos industrializados que não sejam de origem animal, destacadas pelas seguintes providências a título de proteção ao consumidor:

Art $1^{\circ}$ - Fica proibido pôr à vista ou vender sob o nome de "couro" produtos que não sejam obtidos exclusivamente da pele animal.

Art $2^{\circ}$ - Os produtos artificiais de imitação terão de ter sua natureza caracterizada pelo efeito de exposição e venda.

Art $3^{\circ}$ - Fica também proibido o emprego da palavra "couro" mesmo modificada com prefixos e sufixos para denominar produtos não encontrados no art $1^{\circ}$.

Art $4^{\circ}$ - A infração da presente lei constitui crime previsto no art $196 \mathrm{e}$ seus parágrafos do código penal (ABNT).

\subsection{Vacum: couro de origem bovina}

Tanto o "nobuck" quanto o "camurção" procedem das peles bovinas.

A pele bovina serve para a obtenção de couros utilizados na confecção de calçados, bolsas, vestuário e estofamentos. 
Depois de curtido, o couro é usado na fabricação de calçados, bolsas, carteiras, cintos, malas, chapéus, revestimento de móveis, entre outros.

O couro bovino é o mais empregado. Entretanto, tem crescido a procura por couros de origens diversas, como o couro suíno, caprino, ovino e de outras espécies de animais, como o jacaré, a cobra e, atualmente, rã e peixe.

O couro bovino compõe-se de duas partes importantes: a flor e a carnal.

A flor é a parte externa do couro, que, antes do uso, é submetida a tratamentos especiais. A parte carnal é a parte interna, fibrosa. Às vezes, recebe tratamento para substituir a flor.

O couro é considerado de boa qualidade quando apresenta fibras consistentes, elasticidade, boa aparência e facilidade de manipulação.

Pode-se classificar o couro em partes principais e secundárias, cada qual adequada à confecção das peças que vão compor o produto.

A divisão tradicional é a que segue:

1. Culatra ou lombo

2. Espádua

3. Pescoço ou cabeça

4. Garras

5. Barriga

No animal, essa divisão do couro funciona conforme exemplificado nas figuras a seguir:

Figura 32: Mapa 1 explicativo do couro bovino.

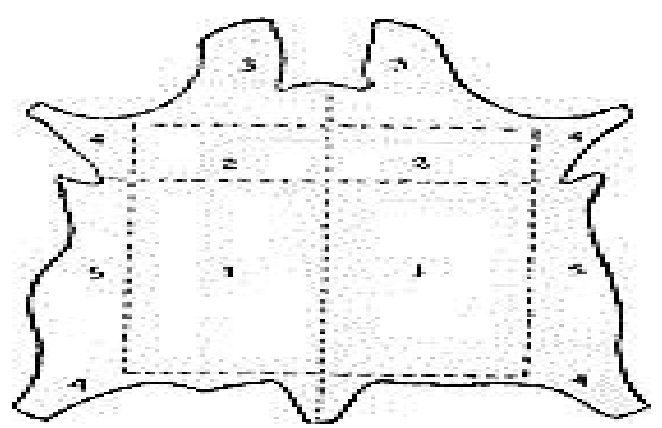

Fonte: 〈http://www.sinacouro.org.br/escola_senai/SENAI_cortador.htm>, acesso em 15 dez. 2013, às 18h59. 
Figura 33: Mapa 2 explicativo do couro bovino.

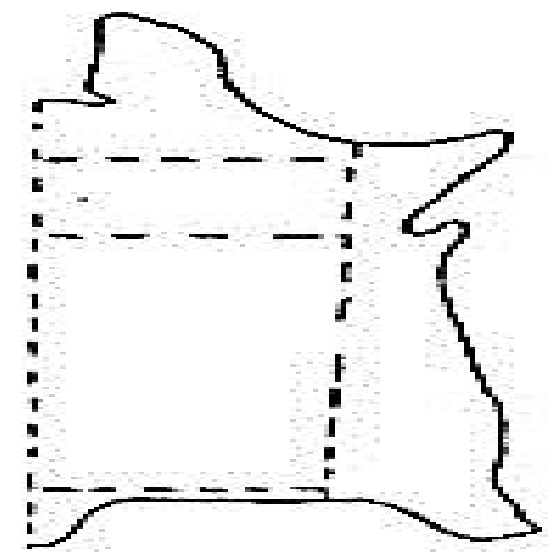

Fonte: <http://www.sinacouro.org.br/escola_senai/SENAI_cortador.htm>, acesso em 15 dez. 2013, às 18 h59.

Figura 34: Figura do boi.

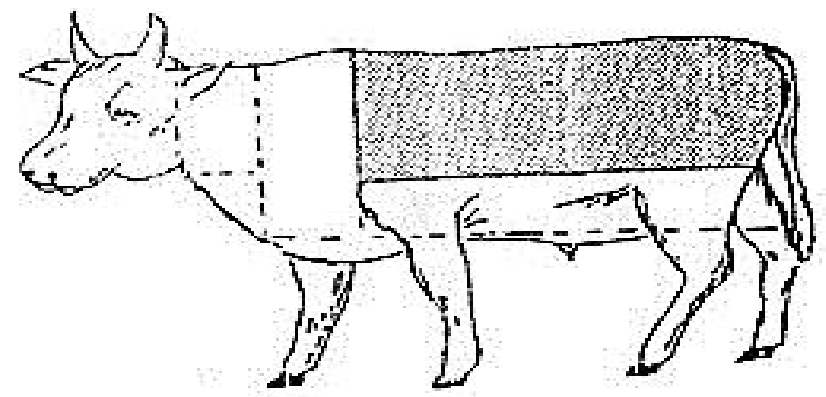

Fonte: <http://www.sinacouro.org.br/escola_senai/SENAI_cortador.htm>, acesso em: 15 dez. 2013, às 19 h02.

As regiões podem ser destacadas, conforme a ilustração a seguir:

Figura 35: Mapa explicativo de corte do couro bovino.

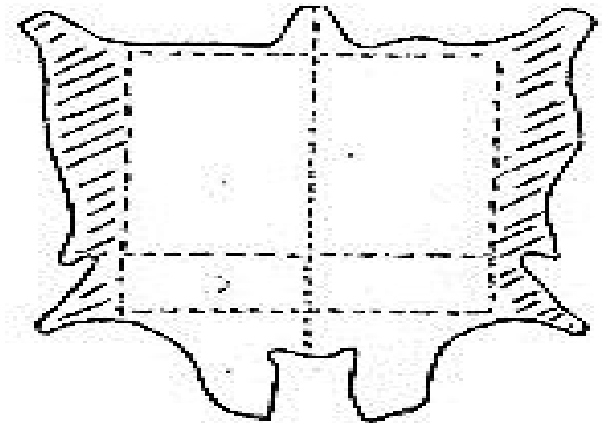

Fonte: <http://www.sinacouro.org.br/escola_senai/SENAI_cortador.htm>, acesso em 15 dez. 2013, às 19 h05.

Quanto ao sentido de elasticidade das fibras, segue ilustração do couro inteiro e dividido ao meio. 
Figura 36: Mapa explicativo de corte do couro bovino. Peça inteira e peça cortada ao meio.
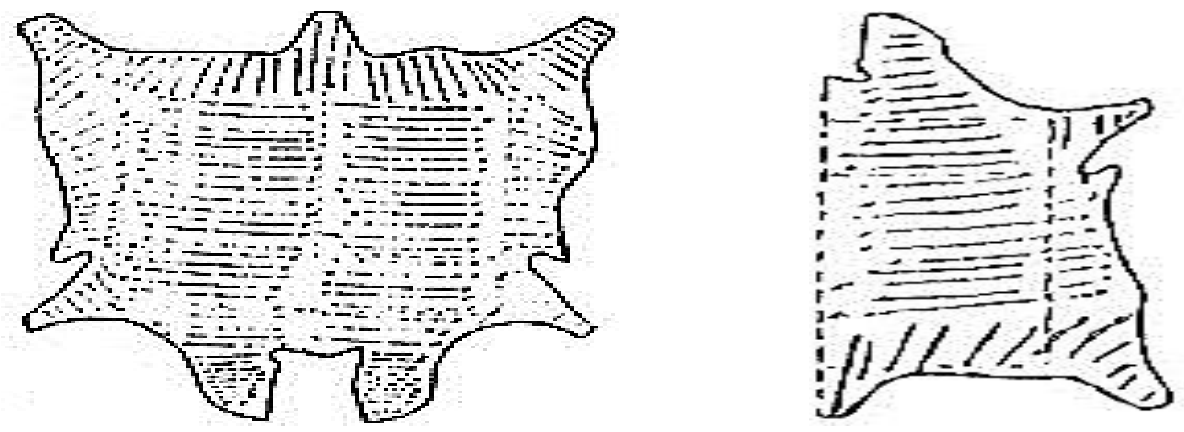

Fonte: <http://www.sinacouro.org.br/escola_senai/SENAI_cortador.htm>, acesso em 15 dez. 2013, às 19 h07.

\subsubsection{Defeitos mais comuns encontrados no couro bovino}

Os defeitos mais comuns encontrados no couro bovino são: marcas de berne e carrapato, cortes de esfola, marcas de fogo, riscos e veias.

As marcas de berne são furos encontrados no couro, causados pela infecção por berne. Em peles envernizadas ou prensadas, deve ser feita uma verificação pelo carnal, pois o defeito normalmente não é visível, por ser coberto pelo verniz ou pelo deslocamento do material próximo ao furo. As marcas feitas pelo aracnídeo carrapato aparecem nos couros que não têm a flor lixada.

Os cortes de esfola - causados por faca - aparecem no couro, às vezes não o transpassando quando da retirada do couro do animal abatido. Marcas de fogo são defeitos causados pelas marcas de identificação do animal, que causam grandes prejuízos aos couros. Riscos são defeitos causados normalmente por chicote, arame farpado ou mirão, e aparecem na flor do couro.

Veias são as artérias do animal, que, por problemas de estrutura, se alargam e ficam perto da flor, aparecendo após o curtimento.

\subsection{Suíno: couro de origem suína}

É o couro obtido da pele do porco. Amplamente usado no vestuário por ser fino, macio e muito resistente à fricção, é dividido em duas partes: flor e raspa. É fácil ser identificado, porque os folículos pilosos são bem desenvolvidos. Tem aspecto parecido com o da pele humana. Por questões de valorização comercial, as peles de porco são comparadas às de antílope.

Em Getúlio Vargas, cidade localizada a 350 quilômetros de Porto Alegre, Rio Grande 
do Sul, na divisa com Santa Catarina, o Curtume Rio-grandense mantém a tradição de processar pele de porco. Segundo o gerente técnico do empreendimento, Nilvo Valdir Fritsch, a empresa já esteve praticamente paralisada anos atrás, mas após o seu retorno da China onde montara um curtume para industriais norte-americanos do setor de calçados -, os proprietários do Rio-grandense decidiram contratá-lo para colocar a planta em operação novamente.

De cara, a reativação criou 70 novos empregos na região. Outras matérias-primas foram experimentadas, mas, após montarem uma rede de fornecedores de pele de porco, decidiram manter o foco em sua vocação inicial.

A crise nos curtumes de pele suína chegou há 15 anos, quando 30 empresas operavam com o material. O motivo foi o surgimento da nova tecnologia desenvolvida para retalhar o animal mantendo a pele junto com a carne, derrubando a oferta de couro.

Os empresários mais capitalizados migraram para o curtimento de couro bovino. Como os fulões - maquinário indispensável nessa indústria - variam conforme o tamanho da pele - a do porco só tem 1 metro quadrado -, os menos aquinhoados simplesmente fecharam por não conseguirem trocar o equipamento.

No Rio-grandense, houve negociação com criadores da região norte do Rio Grande do Sul e do oeste de Santa Catarina. Eles abastecem o curtume. O couro retirado do porco é mais macio em comparação ao bovino, mas a grande quantidade de gordura modifica um pouco o processo, exigindo duas etapas no caleiro ${ }^{2}$, onde é necessário provocar reações químicas mais fortes. Quando sobra gordura na pele, o resultado é um produto que exala odores indesejáveis para peças de vestuário ou acessórios.

Enquanto nessa etapa inicial o couro de boi fica durante 24 horas no processo de curtimento, o do porco fica três dias. Basicamente, a gama de produtos químicos é a mesma, cromo no curtimento, recurtentes, corantes, pigmentos, resinas e vernizes, dependendo da aplicação para a qual a pele está destinada. O mercado interno absorve toda a produção do Rio-grandense. Para cobrir a demanda, a empresa importa matéria-prima - que chega somente salgada e acomodada em contêineres - principalmente da Rússia e do Japão. A produção é de 1,2 mil toneladas ao ano.

A pele de porco é bem mais leve. "Se pegarmos 6 milímetros de uma mesma metragem de couro de porco e de gado, o peso específico é menor", explica Fritsch. Além disso, é um material mais resistente. "Uma pele entre 6 e 8 milímetros de couro suíno pode

- $\quad{ }^{2}$ Processo de adição da cal hidratada a fim de se provocar o intumescimento das peças. 
servir para revestir um sofá. A de boi, com a mesma espessura, rasgaria”, ensina o químico com especialização na Escola de Curtimento de Estância Velha, no Rio Grande do Sul.

Por ter maior capacidade de absorção do suor, graças à sua alta porosidade, o couro suíno é muito utilizado na forração interna de calçados,. O valor também não é o mesmo. Um mesmo modelo de bolsa confeccionado com os couros de boi e de porco terá preço diferenciado: a bolsa feita de couro suíno será mais cara.

O mercado cativo do couro acabado em Getúlio Vargas é o Vale dos Sinos, no Rio Grande do Sul; em São Paulo, as cidades de Birigui, Jaú e Franca; em Santa Catarina, a cidade de São João Batista.

Há ainda os novos centros produtores de calçados da Bahia, de Brasília e na região metropolitana de Fortaleza. O produto serve também para o revestimento de móveis, capas de agendas, carteiras e porta-joias. Certa vez uma decoradora adquiriu uma quantidade significativa de couro de porco em retalhos de diversas cores do Rio-grandense. O material foi transformado nas cortinas da mansão do ex-campeão da Fórmula 1 e da Fórmula Indy, Emerson Fittipaldi, em Miami, nos Estados Unidos.

A especialização da mão de obra, necessária para curtir o couro suíno, acontece dentro do curtume. Segundo Fritsch, as escolas de curtimento passam apenas uma visão geral, pois o foco dos cursos é a preparação da matéria-prima proveniente do rebanho bovino. "A rotatividade da mão de obra é pequena porque couro é resultado de um processo físicoquímico à base de produtos, temperatura e pressão. E o couro de suínos tem suas particularidades", finaliza o gerente técnico.

Figura 37: Manta de couro suíno.

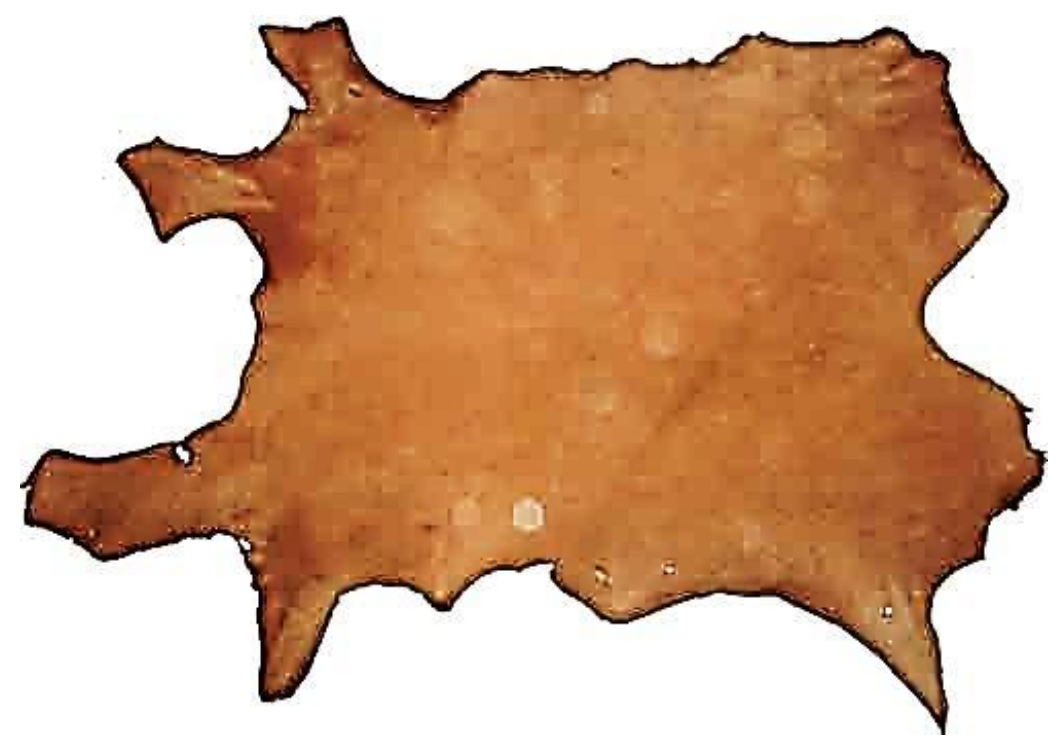

Fonte: <http://www.agenciasebrae.com.br/>, acesso em 22 dez. 2013, às 11h24. 
Figura 38: Luvas confeccionadas com couro suíno.

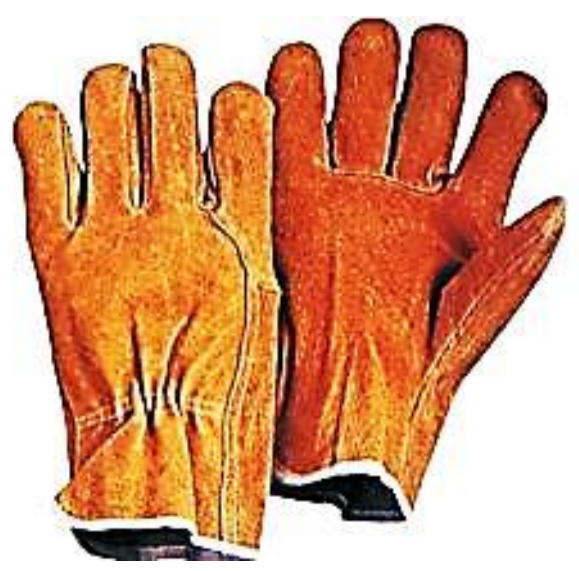

Fonte: <http://www.agenciasebrae.com.br/>, acesso em 22 dez. 2013, às 15 h57.

\subsection{Ovinos e caprinos}

A criação de ovinos e de caprinos está presente em todos os Estados do país, sob exploração familiar e empresarial, sendo as regiões de maior população a Nordeste, com predominância de ovinos sem lã (deslanados) e de caprinos, seguida da região Sul, onde se criam ovinos com lã e a caprinocultura ocupa posição secundária. Nas regiões Sudeste, Centro-Oeste e Norte encontram-se ovinos lanados e deslanados, com predominância dos últimos, sendo a criação de caprinos emergente.

Embora com distintas aptidões econômicas, todos os ovinos, nas diversas condições agroecológicas, são explorados para a produção de carne e, secundariamente, de pele. Situação similar ocorre na criação de caprinos, que tem na indústria do leite uma importante fonte de renda. No Sul, os ovinos são explorados também para a produção de lã e, mais recentemente, de leite; já dos caprinos, obtêm-se também fibras.

De modo geral, em todos os Estados brasileiros a ovino-caprinocultura empresarial está em ascensão, pois o ciclo produtivo desses animais é curto - aproximadamente 210 dias de duração (período transcorrido do acasalamento ao abate da cria) -, o que torna possível a produção de carne e pele, estando a matriz apta para novo ciclo.

Ovinos lanados possuem o corpo coberto por fibras denominadas lã, enquanto os ovinos deslanados e os caprinos são cobertos por pelos, com exceção da raça Angorá, que produz uma fibra têxtil muito macia denominada mohair.

Conforme a cobertura da pele (lã ou pelos), após o curtimento são produzidos artigos diferenciados que atendem à procura crescente nos mercados nacional e internacional por produtos naturais. 
O chamois legítimo é proveniente do carneiro. Trata-se de um couro macio, altamente elástico, que tem a capacidade de absorver e eliminar facilmente grandes quantidades de água. No processo produtivo pode ser submetido à operação de divisão, resultando daí dois tipos de peles.

A camurça legítima é proveniente das peles de cabra. Os vestuários originados de pele de cabra são leves e macios. A pele de cabra é um couro resistente, muito utilizado na fabricação de sapatos e bolsas femininos. Pode ser trabalhado para o vestuário na qualidade de camurça ou couro pelica (liso), em peças como luvas e vestuários com flor integral. Os melhores pergaminhos e couros para encadernação são de cabra. As peles de cabra com a flor lixada apresentam as mesmas características do chamois.

\subsubsection{Camada inferior ou raspa e camada flor}

Depois de curtida, a pele transforma-se em um couro classificado como chamois, que é aplicado na confecção de vestuário, na limpeza de equipamentos ópticos e na fabricação de luvas, sendo ainda empregada em filtros de gasolina.

A camada flor pode ser levada a uma diversidade infinita de curtentes e proporcionam couros finíssimos, principalmente os curtidos brancos. São empregados em vestuários, bolsas, sapatos e encadernações.

O mestiço é a pele bruta de diversas espécies de carneiro, cuja porção de pele é constituída de pelos que apresentam similaridades com os da cabra (pelica).

Quanto à origem não há uma literatura definida a respeito das peles dos mestiços, assim chamados porque originam-se do cruzamento entre caprinos e ovinos, designados como Sem Raça Definida (SRD).

Os vestuários originados das peles de mestiços são os mais leves, nobres e possuem preço e procura elevados no mercado. São fáceis de identificar por apresentarem excelente resistência, maciez e um toque sedoso. As roupas confeccionadas com esse tipo de couro podem ser do tipo camurça, chamois e napa.

Camurça: o couro permanece com a flor. Porém, no acabamento, objetiva-se o carnal do couro.

Chamois: quando se utiliza a parte carnal ou parte inferior da divisão do couro ou através de efeito (retirada da flor com lixadeira), ganhando a denominação de chamois. 
Napa: o uso desse couro pela parte superior (flor integral) é denominado napa. As napas oriundas das peles mestiças são as mais procuradas para a confecção de vestuários.

Figura 39: Couro ovino.

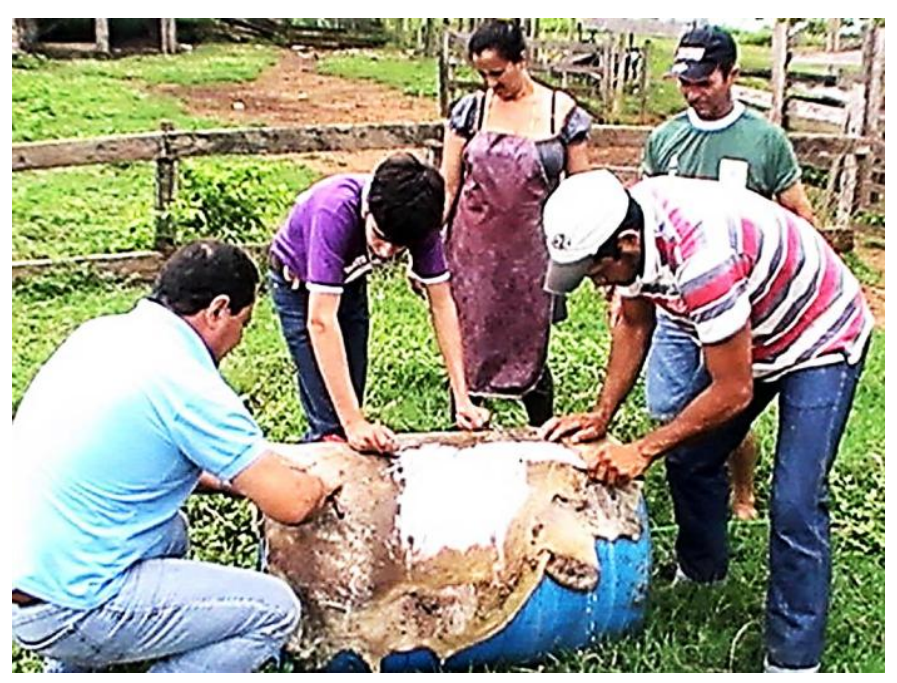

Fonte: <http://www.agenciasebrae.com.br/>, acesso em 22 dez. 2013, às 18h43.

Figura 40: Mantas de couro ovino.

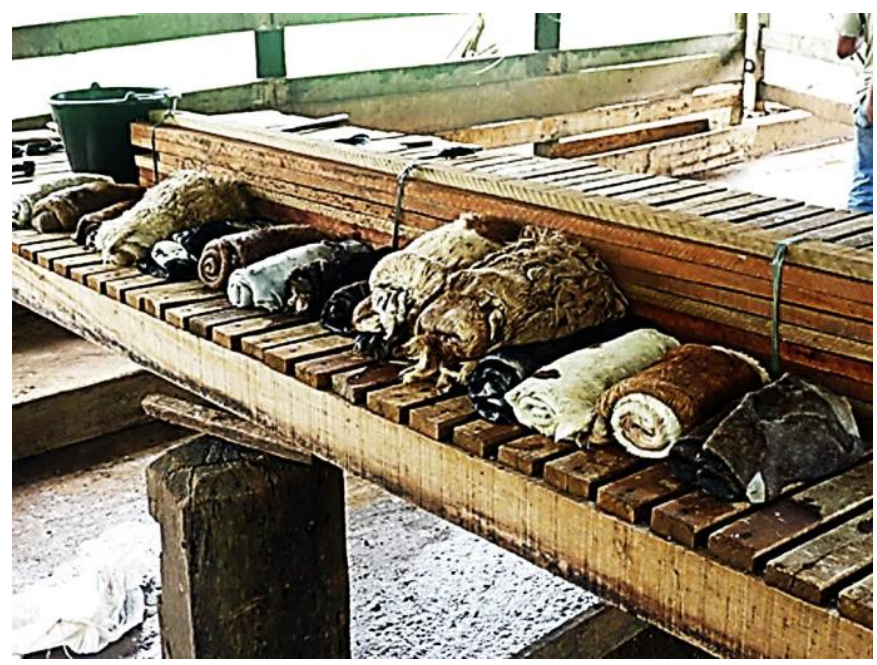

Fonte: <http://www.agenciasebrae.com.br/>, acesso em 02 jan. 2014, às 18h30.

Figura 41: Manta de couro caprino. 


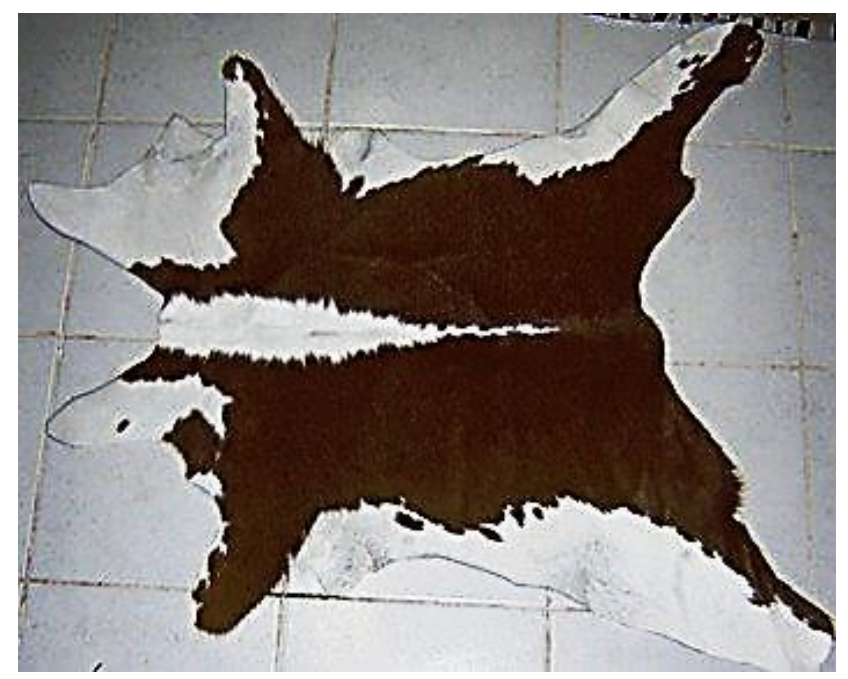

Fonte: <http://www.agenciasebrae.com.br/>, acesso em 02 jan. 2014, às 19h45.

Figura 42: Mantas de couro caprino.

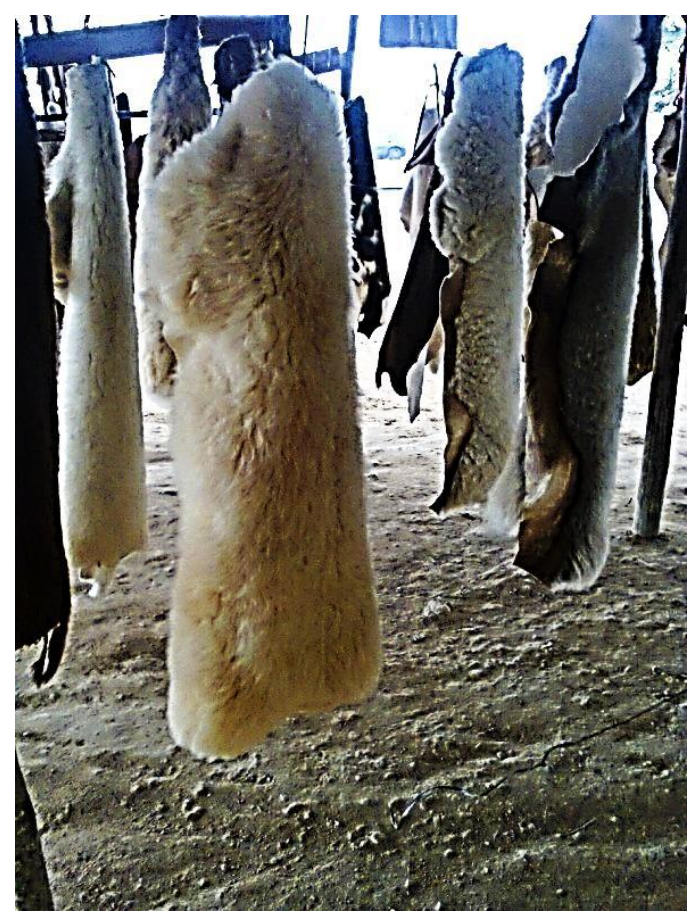

Fonte: <http://www.agenciasebrae.com.br/>, acesso em 02 jan. 2014, às $20 \mathrm{~h} 32$. 


\section{MOLDES, CORTE E BENEFICIAMENTO DO COURO}

São usados moldes para facilitar e tornar mais rápido o corte das peças componentes de cintos, carteiras, bolsas, pastas, entre outros.

Os moldes representam cada uma das partes de um modelo do produto. Portanto, há vários conjuntos de moldes, de acordo com a quantidade de modelos.

Os moldes podem ser de papelão, chapas galvanizadas ou de aço. Os de papelão são mais apropriados a cortes manuais. Suas bordas são revestidas com filete metálico para oferecerem segurança ao cortador, durabilidade ao molde e boa qualidade ao corte. Periodicamente, esse tipo de molde deve ser substituído, pois, devido ao uso repetido, acaba apresentando deformações.

O molde de aço é próprio para cortes mecânicos. Consta de uma fita de aço moldada conforme o contorno das peças do modelo. Suas bordas são afiadas, em um ou nos dois lados. Mediante o impacto de uma prensa, conhecida como balancim, efetua-se o corte da peça. A peça deve ser colocada sobre uma superfície rígida, denominada cepo, que seja forte o suficiente para resistir ao impacto do corte.

O molde de aço apresenta vantagem em relação ao molde de papelão. As peças cortadas mecanicamente apresentam corte mais exato, proporcionando perfeita semelhança entre peças cortadas e moldes.

Entretanto, os moldes de aço são de custo alto, sendo empregados somente quando se visa atingir elevada produtividade de um mesmo modelo.

Os moldes devem ser guardados em local seco e protegidos do calor, para não sofrerem empenamento. Os moldes de aço não devem ser empilhados, pois o choque entre eles pode danificar o corte.

\subsection{Ordem de produção}

A ordem de produção consta de uma ficha contendo orientações para as operações a serem executadas.

Essas orientações referem-se ao modelo, material, cor, forro, referência e quantidade de peças a serem cortadas. Inclui ainda solicitações: quantidade de material prevista para uso e a que foi realmente consumida, nomes dos operadores envolvidos nas diversas etapas de 
fabricação, tempo previsto e realização das tarefas.

\subsection{Aproveitamento racional do material}

As peças naturais, como o couro, são assimétricas, exigindo muita astúcia e habilidade do cortador no sentido de posicionar bem os moldes para aproveitar, o melhor possível, o material a ser cortado.

Os moldes devem ficar tão unidos quanto possível, para evitar espaços que resultem em perda de material.

Para identificar o melhor posicionamento dos moldes deve-se girá-los ou virá-los em posições diversas até se encontrar a disposição ideal.

Também para evitar desperdícios de material, o corte deve ser feito rente aos moldes, com movimentos firmes da faca, se for o caso de corte manual. Um bom cortador não ultrapassa os limites dos moldes, o que requer atenção e habilidade.

O corte deve obedecer a uma ordem decrescente, ou seja, começa-se o corte pelos moldes maiores e em maior quantidade, até chegar aos menores.

Em síntese, a boa qualidade do corte depende de conhecimentos e do domínio das técnicas de corte. Seja em bolsas finas ou em itens mais grosseiros, o corte deve ser sempre de boa qualidade, porque ele vai influir na aparência e na estrutura do produto.

O corte a fio, necessário em todas as peças, exige firmeza e equilíbrio no uso do gume da faca.

Figura 43: Corte a fio.

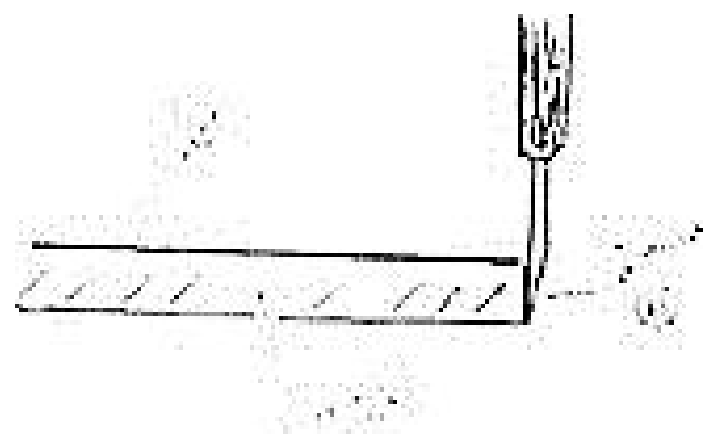

Fonte: <http://www.agenciasebrae.com.br/>, acesso em 18 dez. 2013, às $12 \mathrm{~h} 57$.

Segundo o site Safra Notícias (2013), outro aspecto a ser observado no processo do corte, refere-se à marcação. Ela deve ser bem feita e legível. Marcam-se as peças cortadas 
com números anotados em locais corretos. Depois conferem-se as quantidades das peças para verificar se elas correspondem exatamente à quantidade solicitada na ordem de produção.

\subsection{Ferramentas}

As principais ferramentas de corte são: faca de cortador, lima e pedra de afiar.

\section{- Faca de Corte}

Usada, principalmente, para cortar peças de couro sintético ou peças similares. Compõe-se de suporte (cabo) e lâmina (SAFRA NOTÍCIAS, 2013).

\section{$\underline{\text { Suporte }}$}

Podemos usar três tipos de suporte, a saber:

\section{a) Suporte de arame}

Figura 44: Suporte de arame.

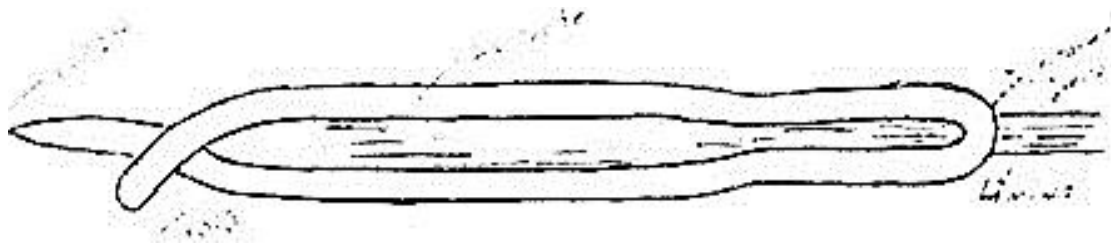

Fonte: <http://www.agenciasebrae.com.br/>, acesso em 18 dez. 2013, às 13 h15.

O suporte sustenta a lâmina; assim, protege e facilita a pegada da faca pelo cortador.

Os tipos de suporte mais usados são de arame ou de couro. Os de arame são feitos em aço cilíndrico, moldados de forma que em uma de suas extremidades seja introduzida uma lâmina e, na outra, se forme uma punção, usada para marcar pontos do modelo e retirar rebarbas (SAFRA NOTÍCIAS, 2013).

\section{b) Suporte de cano}

Figura 45: Suporte de cano.

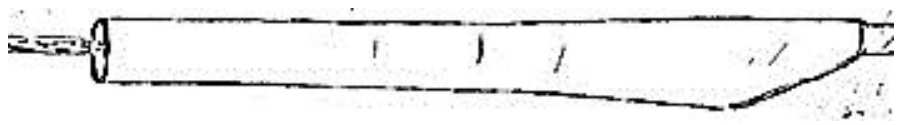

Fonte: <http://www.agenciasebrae.com.br/>, acesso em 18 dez. 2013, às $13 \mathrm{~h} 30$. 
O suporte de cano consta de um tubo de aço ou alumínio com, aproximadamente, 15 cm de comprimento. Uma das extremidades é achatada e cortada transversalmente, sendo que nela se encaixa a lâmina. Uma vareta de aço com ponta em forma de cunha é introduzida no tubo para prender a lâmina. Outra vareta, na extremidade oposta, serve para marcar o ponto do modelo e retirar rebarbas.

\section{c) Suporte de capa}

É uma chapa de latão que reveste a lâmina para lhe dar firmeza e proteger a mão do operador.

\section{- Lâmina}

Figura 46: Lâmina.

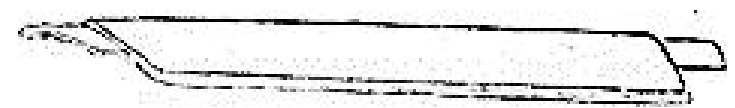

Fonte: <http://www.agenciasebrae.com.br/>, acesso em 18 dez. 2013, às 14h33.

A lâmina, parte cortante da faca, é de aço temperado. É flexível, tem formato achatado, mede $5 \mathrm{~mm}$ a $8 \mathrm{~mm}$ de largura e 0,35 a $0,50 \mathrm{~mm}$ de espessura.

A lâmina é presa ao suporte e, geralmente, utiliza-se lâmina de serra manual de mola de relógio.

\section{- Pedra de afiar}

Também utilizada para afiar o gume da faca, retirar rebarbas deixadas pela lima e corrigir o fio de corte.

A pedra de afiar pode ser de duas faces, uma de carborundum de grana grossa e outra de grana fina.

Para sua correta conservação, deve-se umedecê-la diariamente em água ou óleo. Ademais, deve ser lixada quando apresentar área irregular.

\subsection{Zonas da pele}


Conhecer e identificar corretamente as zonas de uma pele de couro é fundamental para todos os profissionais do setor, que atuem em qualquer etapa da produção.

São informações básicas que garantem o melhor aproveitamento tanto da matériaprima trabalhada como do produto final.

Figura 47: Figura explicativa das zonas da pele.

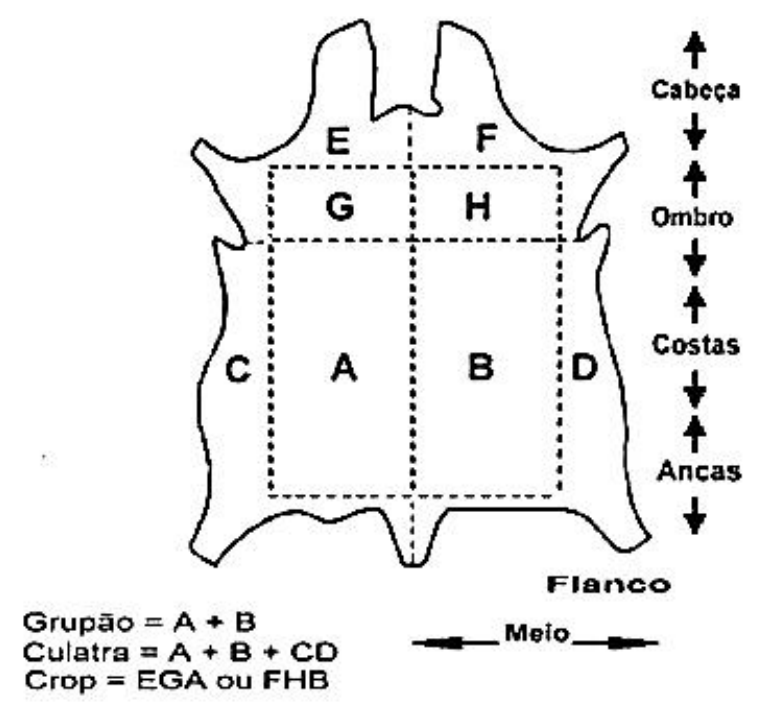

Fonte: <http://www.agenciasebrae.com.br/>, acesso em 03 jan. 2014, às 21 h36

Algumas características das peles variam em função da raça do animal, clima, alimentação, tipo de criação, entre outros. Como nem todas as peles são iguais, é um desafio para os curtidores obter couros uniformes.

Figura 48: Ilustração tradicional.
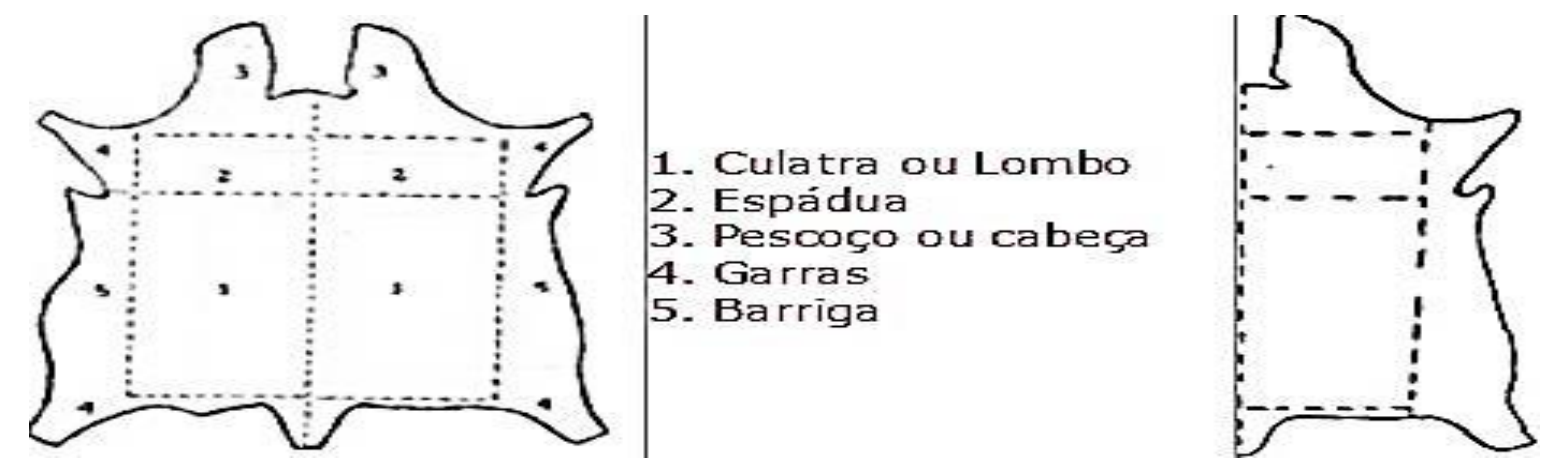

Fonte: <http://www.agenciasebrae.com.br/>, acesso em 03 jan. 2014, às $22 \mathrm{~h} 32$

Figura 49: Ilustração animal. 


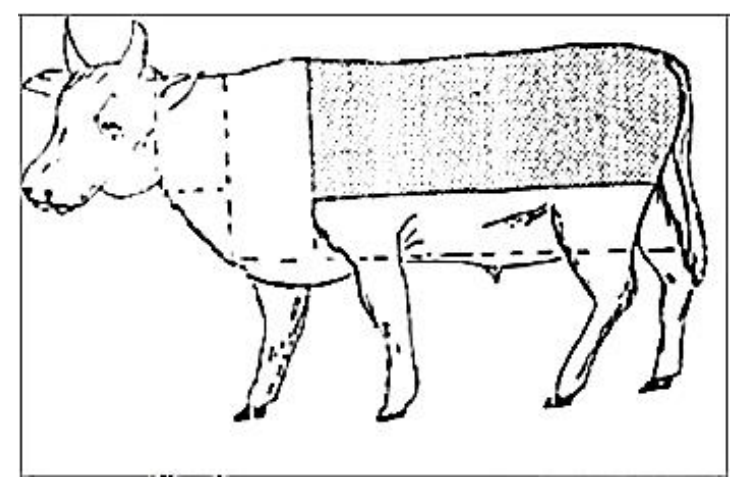

Fonte: <http://www.agenciasebrae.com.br/>, acesso em 03 jan. 2014, às $22 \mathrm{~h} 45$

Figura 50: Destaque das regiões.

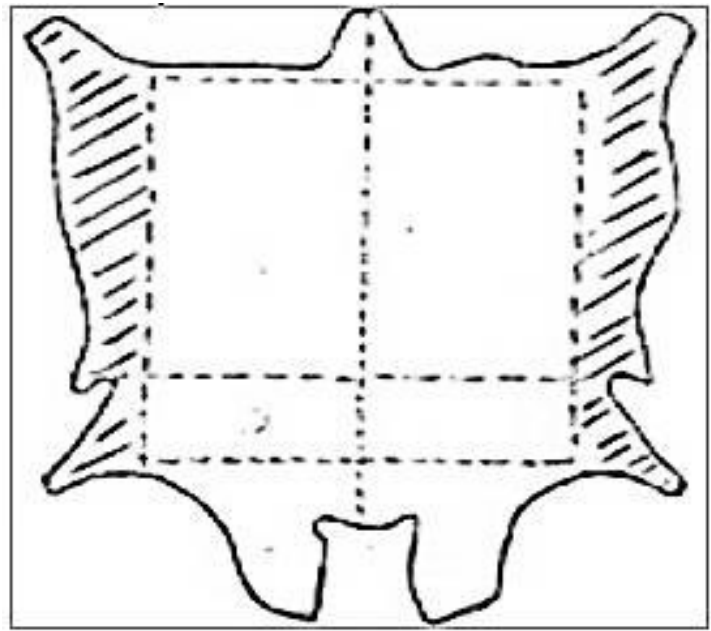

Fonte: <http://www.agenciasebrae.com.br/>, acesso em 03 jan. 2014, às 23h15

Figura 51: Sentido da elasticidade das fibras no couro inteiro e no couro dividido ao meio.

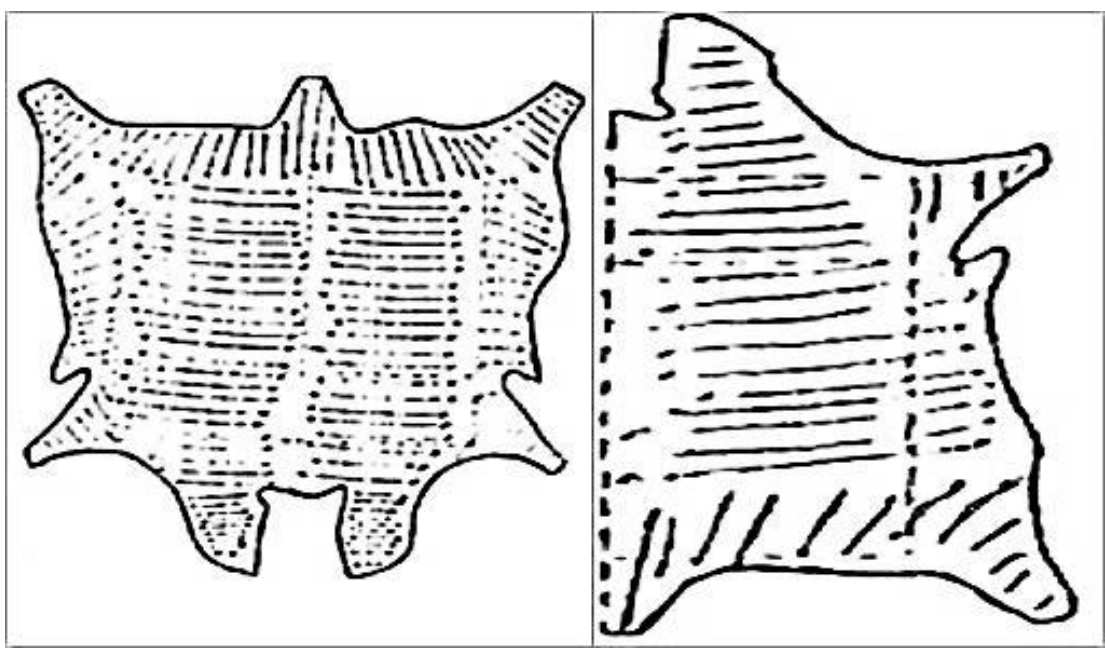

Fonte: <http://www.agenciasebrae.com.br/>, acesso em 04 jan. 2014, às $07 \mathrm{~h} 25$

A qualidade da pele curtida, a sua flexibilidade, a textura do aveludado e a sua resistência dependem da estrutura fibrosa, ou seja, da magreza de suas fibras individuais e do seu tecido intermediário. O curtidor, pela sua forma de trabalhar, pode variar a magreza das fibras do feixe e a firmeza do tecido, de forma que se pode produzir, de um só tipo de material 
bruto, curtidos com variações na suavidade, no caimento e no tato. A sua habilidade centra-se em eleger uma pele e produzir um curtido com as propriedades especiais requeridas para um fim específico. As propriedades requeridas para a confecção são bastante diferentes das utilizadas para a parte superior do calçado, por exemplo.

Apesar disso, há variações naturais em uma mesma pele, nas peles do mesmo tipo de animal, e não há como isso ser modificado. Deste modo, conhecer essas variações é fundamental para a obtenção de resultados satisfatórios ao se cortar uma pele para confecção.

O grupão, ou a zona central da pele, tem um tecido fibroso compacto, pois as suas fibras estão entretecidas em forma de ângulo médio à superfície. Isso proporciona um curtido com textura firme e menos tendência a quebras, além de menor propensão à formação de vincos tesos ao se dobrar o couro suavemente para dentro. $\mathrm{O}$ aveludado da camurça é firme e fino (SAFRA NOTÍCIAS, 2013).

Nos flancos, as fibras se entrelaçam menos e o tecido é mais solto, com fibras de ângulo menor em relação à superfície. Proporcionam curtidos com textura menos firme e apresentam mais tendência a quebras, sendo as fibras do aveludado mais longas. Essa tendência seria mais acentuada com a aplicação de uma camada de polímero, por exemplo, à entretela. Por isso, é pouco recomendável utilizar a pele dos flancos para as peças centrais de um vestuário ou para paramentos das lapelas, punhos, cotovelos, bolsos, entre outros. A pele dos flancos não é necessariamente frouxa (SAFRA NOTÍCIAS, 2013).

\subsection{Beneficiamento do couro}

\subsubsection{Curtimento}

O processo de transformação de peles em couros é normalmente dividido em três etapas principais, conhecidas por ribeira, curtimento e acabamento. $\mathrm{O}$ acabamento, por sua vez, é usualmente dividido em "acabamento molhado", "pré-acabamento" e "acabamento final".

Os quadros abaixo mostram, em duas partes, um fluxograma genérico do processamento completo para a fabricação de couros, desde as peles frescas ou salgadas até os couros totalmente acabados, destacando-se os principais pontos de geração de resíduos.

Figura 52: Fluxograma esquemático da fabricação de couros - operações de ribeira, curtimento e acabamento molhado. 


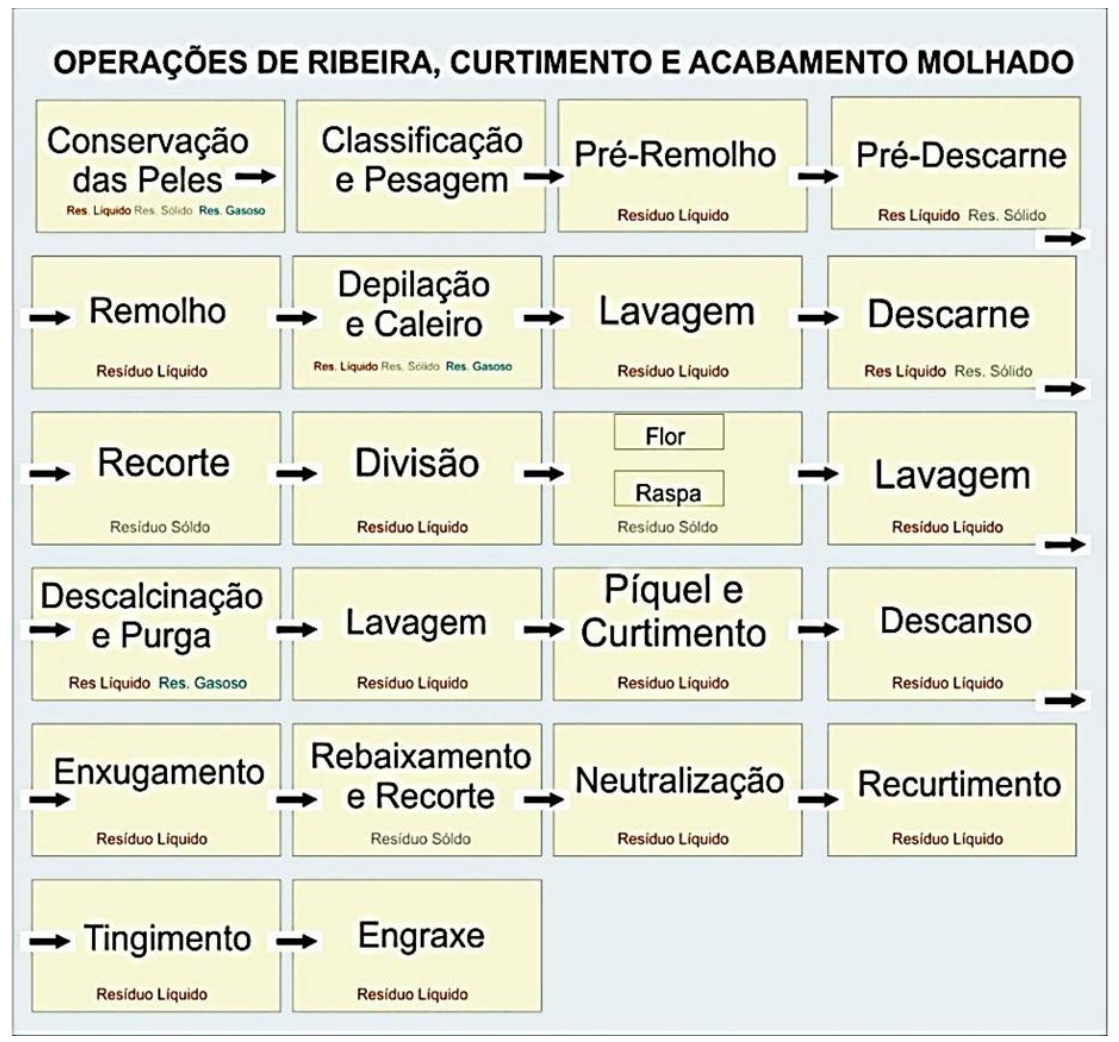

Fonte: <http://www.sinacouro.org.br/escola_senai/SENAI_cortador.htm>, acesso em 15 dez. 2013, às 19 h15.

Figura 53: Fluxograma esquemático da fabricação de couros - operações de acabamento.

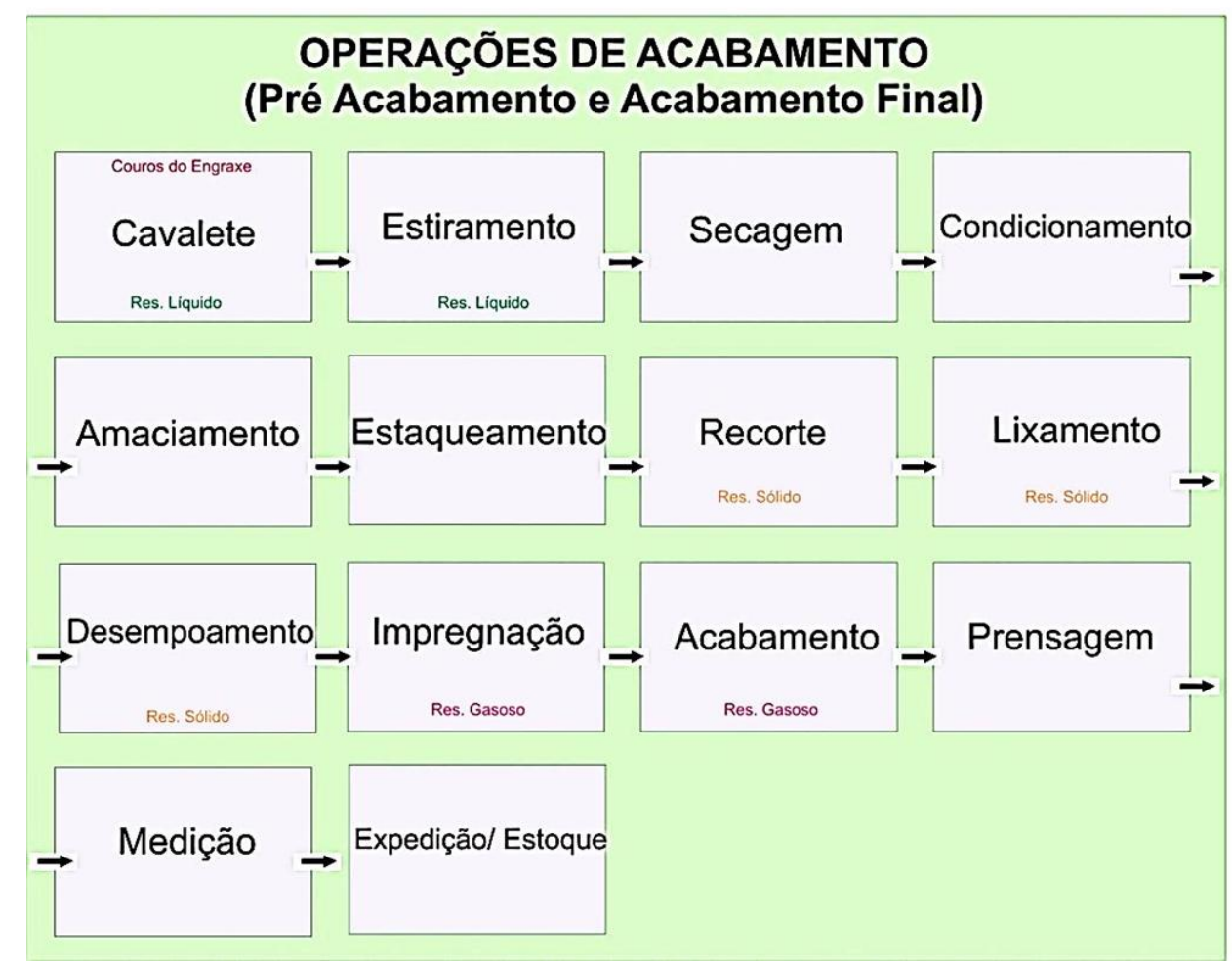

Fonte: <http://www.sinacouro.org.br/escola_senai/SENAI_cortador.htm>, acesso em 15 dez. 2013, às 19 h23.

Os curtumes são normalmente classificados em função da realização parcial ou total dessas etapas de processo. Desta forma, há os seguintes tipos de curtumes: 
- Curtume integrado: capaz de realizar todas as operações descritas nas figuras anteriores, desde o couro cru (pele fresca ou salgada) até o couro totalmente acabado.

- Curtume de "wet-blue": processa desde o couro cru até o curtimento ao cromo ou descanso e enxugamento após o curtimento; o nome "wet-blue" se deve ao aspecto úmido e azulado do couro após o curtimento com o cromo.

- Curtume de semiacabado: utiliza o couro "wet-blue" como matéria-prima e o transforma em couro semiacabado, também chamado de "crust".

\subsubsection{Tipos de curtimento}

Existem diversos tipos de curtimento para couros. São eles: curtimento mineral inorgânico, curtimento vegetal orgânico, curtimento misto, curtimento de preservação e recurtimento (CENTRO DO COURO, 2013).

O curtimento mineral inorgânico mais comum é realizado com sais de cromo trivalente (cromo III). O couro é denominado "wet-blue" quando curtido unicamente com sais de cromo. Pelas características dos couros obtidos - elevada maciez, elasticidade, baixo peso específico, estabilidade à luz, toque, entre outras -, esses couros são os mais empregados na fabricação de vestuários.

O curtimento orgânico mais comum é o realizado com taninos vegetais, combinados ou não com taninos sintéticos, entre outros. Pelas características dos couros obtidos - maior peso específico, menor estabilidade à lavagem -, estes couros não são normalmente empregados para a fabricação de vestuário.

O curtimento misto é aquele realizado com produtos de origem de síntese, como o glutaraldeído e fenóis, que fornecem aos couros características específicas, como resistência a lavagens e baixo peso específico. Essa combinação é indicada também para o pré-curtimento.

Quando o couro não é curtido com o cromo, mas sim com engraxes superficiais, temos o curtimento de preservação.

Já o processo de recurtimento ocorre quando são definidas características desejadas no couro, como enchimento, elasticidade, resistências, lixabilidade, facilidade de reter estampas, entre outras. O recurtimento pode ser combinado ao emprego de curtentes orgânicos, inorgânicos ou de síntese (como, por exemplo, derivados de melanina, fenol, acrílico e dicianodiamida) adequadamente aplicados. 
5.5.3 Classificação dos couros de acordo com o curtimento/recurtimento

- Cromo

Couro curtido e recurtido ao cromo "wet-blue".

- Atanado

Couro curtido com curtentes (tanino) vegetais. Conhecido como "couro vegetal".

- Semicromo

Couro curtido ao cromo e recurtido com curtentes vegetais.

- Wet-white

Couro de coloração branca, curtido com alumínio, zircônio, formol ou aldeído glutárico, que não sofreu nenhuma operação complementar e que permanece úmido, podendo ser estocado ou comercializado nesse estado. Pode ser considerado curtido de preservação.

\subsection{Máquinas, equipamentos e artefatos facilitadores do processo}

\subsubsection{Construções}

As construções são simples e constam de galpão e tratamento de efluentes. O galpão é dividido em dois setores: curtimento e acabamento, com pé-direito normalmente de $4 \mathrm{~m} \mathrm{e}$ paredes e pisos laváveis, sendo que no setor de curtimento o piso tem ligeira inclinação e calhas de drenagem direcionadas à estação de tratamento de efluentes.

Preferencialmente, deve-se procurar reduzir os custos da construção, utilizando-se dos recursos e materiais mais prontamente disponíveis.

\subsubsection{Equipamentos}

Os equipamentos para o setor de curtimento são os seguintes: 2 fulões de remolho (caleiro), 2 fulões de curtimento, 2 fulões de recurtimento, balcão, tanque, descarnadeira manual, balança, freezer e 2 cavaletes. 
Figura 54: Fulão de remolho (à esq.), fulão de curtimento (centro) e descarnadeira manual (à dir.).
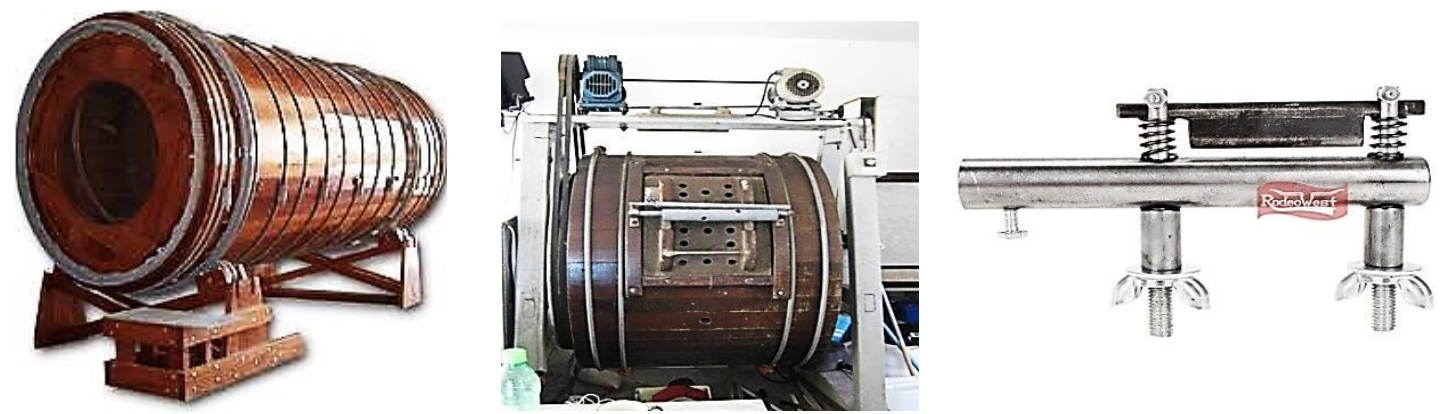

Fonte: <http://www.michelon.ind.br/detalhe-produto/maquinas/remolho-continuo>, acesso em 10 jan. 2014, às 18h14. <http://www.fimec.com.br/noticias/noticias.php?id=42>, acesso em 10 jan. 2014, às 19h01. Fonte: <http://www.bremmpeck.com.br/rec_01.php>, acesso em 10 jan. 2014, às 20h24.

Os equipamentos para o setor de acabamento são os seguintes: estufa elétrica, roda de amaciar, fulão de amaciar, 2 quadros de madeira, 2 cabines de pintura, prensa hidráulica, balcão e tanque.

Figura 55: Modelos de prensa hidráulica.
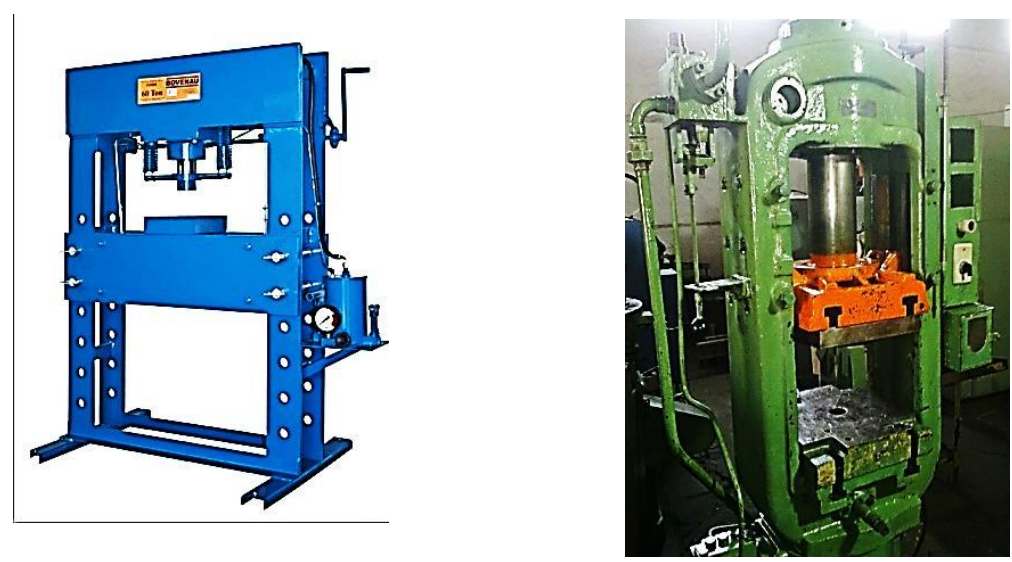

Fonte: <http://www.salvagnini.com.br/news.php?s=954>, acesso em 11 jan. 2014, às 06h52.

<http://sumare.olx.com.br/prensa-hidraulica-modelo-jacare-prensa-latinha-perfil-chaparia-iid-542832061>, acesso em 11 jan. 2014, às 07h12.

Os fulões são equipamentos cilíndricos, tambores rotativos em torno do próprio eixo e colocados paralelamente à horizontal, existentes em várias dimensões. Sua função é desenvolver processos físico-químicos de transformação de peles em couro. Em empreendimentos mais simples e de menor investimento, recipientes de plástico ou fibras de vidro podem substituir os fulões e desempenham os mesmos processos, porém, demora-se mais para a efetivação das reações.

Os balcões devem ser de preferência de madeira para permitir a colocação de recipientes com produtos químicos, armazenar materiais e até mesmo servirem de bancada para anotações e outras coisas. 
Os tanques comuns são locais para a lavagem de recipientes, peles e materiais diversos. A descarnadeira manual é o equipamento utilizado para remover resíduos aderidos à superfície do carnal, como restos de carne, gorduras, fibras, entre outros.

As balanças são de dois tipos: uma, para pesagem de peles; outra, semianalítica (balança Marte com capacidade para $1610 \mathrm{~g}$ ), para pesagem de produtos químicos e tintas (CENTRO DO COURO, 2013). 


\section{COURO DE PEIXE}

\subsection{Início, desenvolvimento e continuidade}

A fabricação e comercialização do couro de peixe teve seu início na década de 70 . Tratando-se de uma iniciativa voltada ao aproveitamento do rejeito da indústria pesqueira, passou a chamar sutilmente a atenção do mercado.

A produção de couro de peixe é ecologicamente reconhecida e só traz benefícios, por se tratar de uma técnica sustentável. Produzir este couro é sinônimo de conservação do meio ambiente e do reaproveitamento de uma matéria-prima que atende inclusive às necessidades estéticas.

É um elemento que, quando transformado em substrato têxtil, passa a ser benéfico à sociedade como um todo e ao meio ambiente. Muitos quilos deste couro são desperdiçados por dia, visto que o consumo da carne de peixe é comum em quase todos os países do mundo. Quando o animal é pescado e levado ao frigorífico ou às peixarias para comercialização da sua carne, seu couro é descartado em mares e rios, causando assim poluição biológica, que afeta a flora e a fauna compositoras da região - e também o homem (CENTRO DO COURO, 2013).

As atividades da indústria pesqueira são intensas e o reaproveitamento de seus rejeitos é de extrema importância, sendo reconhecido como uma atitude sustentável e responsável ambientalmente.

Entre outras características do couro de peixe, podemos apontar a resistência da matéria-prima, sua aplicabilidade em vários produtos de alto valor agregado, "esfola” após o abate e conservação mediante seu congelamento.

A pele pode ser beneficiada e resultar em uma matéria-prima de qualidade e de aspecto peculiar inimitável, após o curtimento, devido à sua resistência e desenho formado na sua superfície, principalmente as peles de peixes com escamas. As características do produto obtido, como: a resistência da matéria-prima, suas características exóticas e sua aplicabilidade em vários produtos de alto valor agregado vêm despertando a curiosidade e o interesse de muitos empreendedores.

Muitos designers e estilistas já produzem e confeccionam esse couro, incluindo-o em suas coleções e atraindo a atenção dos consumidores. Pode ser utilizado em peças do vestuário, assim como em acessórios. A produção desse couro é viável e permite criações em 
muitos setores, além da área têxtil.

A atividade vem sendo explorada comercialmente não só por meio de parcerias com as empresas de pesca, tanto as de água doce quanto salgada, mas também com criatórios de peixes espalhados pelo País. O mercado da moda já reconhece o valor e a importância do uso do couro de peixe na fabricação de acessórios como bolsas, cintos, carteiras e sapatos. Apesar das iniciativas econômicas atualmente explorarem de forma artesanal o uso dessa matériaprima, grandes mercados consumidores, altamente qualificados, vêm buscando de forma agressiva a diferenciação em suas criações mediante o emprego de materiais alternativos, com apelo socioambiental e ecológico. Devido a esse tipo de apelo, importantes eventos e grifes prestigiadas voltam os olhares para o couro de peixe, tratando-o como uma matéria-prima exótica, exclusiva e, por isso, valorizada no mercado.

A importância dada ao uso de matérias-primas alternativas, com o apelo do "politicamente correto", torna a atividade econômica do curtume de couro de peixe inovadora e altamente promissora.

Segundo o SEBRAE (2014), o setor curtidor é de grande importância para a economia brasileira. Vale lembrar que a cadeia produtiva do couro, que envolve os segmentos de curtumes, calçados, componentes, máquinas e equipamentos para calçados e couros, artefatos e artigos de viagem em couro, reúne 10 mil indústrias, gera mais de 500 mil empregos e movimenta receita superior a 21 bilhões de dólares por ano.

Ainda de acordo com o SEBRAE (2014), de modo geral, existem atualmente 450 curtumes no Brasil, dos quais cerca de $80 \%$ são de pequeno porte, empregando de 4 a 99 trabalhadores cada um. Os países europeus são exigentes e inovadores no uso desses materiais, e valorizam o apelo das características de exclusividade. Já os países asiáticos são atraídos pelas características exóticas da matéria-prima.

Em âmbito geral, a grande barreira a ser vencida pelos empreendedores que se dedicam a essa atividade econômica está relacionada ao processo de obtenção e beneficiamento da matéria-prima. O mercado está interessado em adquirir e utilizar o produto, mas quer saber e acompanhar as técnicas utilizadas para sua obtenção e processamento, sob pena de se perder o caráter ecológico tão valorizado.

O SEBRAE (2014) afirma que uma característica peculiar desse tipo de negócio é que, apesar de depender de uma atividade econômica extremamente fechada e de difícil entrada que é a da indústria pesqueira -, o empreendedor não precisa ser do meio. Geralmente, o couro do peixe é considerado lixo e problema para os pescadores, e ainda pode ser negociado 
a preços simbólicos apenas para favorecer a destinação final adequada do material. Este fato pode ser muito bem aproveitado pelo empreendedor que pretende explorar a atividade do curtume de couro de peixe, uma vez que a produção anual brasileira de pescados gira em torno de 800.000 toneladas/ano, e o couro representa de 8 a $12 \%$ deste valor total.

De acordo com Reis apud Kotler (2007), um produto é considerado qualquer artigo que tenha como objetivo satisfazer uma necessidade específica de um consumidor. No entanto, um produto pode ser algo tangível (um bem, por exemplo) ou intangível (um serviço ou uma marca). Em resumo, qualquer coisa que possa ser expressa em valor monetário, como uma ideia, é considerado um produto. Um produto continuará vivo no mercado desde que atenda às necessidades impostas pelos consumidores, sendo essas necessidades facilmente perceptíveis ou não tão claras, mas o delimitam-no dentro de um grupo ou estilo de vida.

O conceito de ciclo de vida do produto (CVP) surge uma vez que o mercado, os consumidores e os concorrentes esteja em constante mudança, exigindo estratégia de posicionamento e diferenciação das empresas para garantir seu sucesso por meio de gerenciamento do volume do investimento em cada etapa do ciclo de vida.

Segundo Kotler (2006), ao se dizer que um produto possui um ciclo de vida, é necessário aceitar os seguintes fatores: os produtos têm ciclo de vida limitada; as vendas dos produtos passam por estágios distintos, cada um deles com desafios, oportunidades e problemas diferentes para as empresas; os lucros sobem e descem nos diferentes estágios do ciclo de vida do produto; os produtos necessitam de diferentes estratégias de produção, financeira, marketing, compras e recursos humanos, de acordo com cada estágio do seu ciclo de vida.

Kotler (2006) utiliza o conceito de que a curva do CVP é dividida em quatro estágios:

1- Desenvolvimento de produto ou introdução ou lançamento do produto: período de baixo crescimento das vendas e alto custo de produção associado, já que o volume de produção/vendas não permite economia de escala. Nesta fase, o produto requer altos investimentos em tecnologia, propaganda, distribuição e embalagem/design. O lucro é negativo.

2- Crescimento: período em que uma significativa parcela dos consumidores toma conhecimento da existência do produto, o que eleva seu volume de vendas e favorece o surgimento da economia de escala. Começam a surgir os concorrentes, o que faz com que a empresa invista em diferenciação para não perder a parcela de mercado que já conquistou. Com o aumento da oferta, os preços caem. Nesta fase, a empresa recupera todos os 
investimentos e o lucro aumenta.

3- Maturidade: período caracterizado por baixa no crescimento das vendas, já que os consumidores potenciais já foram conquistados. Os lucros diminuem ou se estabilizam no final deste estágio em função do aumento da concorrência.

4- Declínio: o produto atinge sua obsolescência e é substituído pelo concorrente mais inovador. Neste momento a empresa para de investir em distribuição, propaganda e desenvolvimento e começa a discutir qual o melhor momento de retirar o produto do mercado ou reposicioná-lo em outro nicho.

Kotler (2006) ressalta que nem todos os produtos passam por todos os estágios de ciclo de vida. Isso ocorre porque alguns produtos morrem antes de chegar à maturidade ou até mesmo o primeiro estágio por erros de estratégia ou posicionamento de mercado. Assim, o lançamento constante de novos produtos é uma estratégia das organizações para que se alcance o sucesso e se garanta um ciclo de vida mais duradouro. Em contrapartida, alguns produtos têm uma aceitação tão grande pelo mercado que podem passar logo do estágio de introdução para a maturidade.

Ainda segundo Kotler (2006), outros produtos podem passar da fase da maturidade para um crescimento lento, afastando-se o estágio de declínio por algum tempo. Isso se deve a um forte investimento em propaganda e caracteriza o chamado reciclo.

Adoção é a decisão de alguém de se tornar usuário regular de um produto (Kotler, 2006). A adoção é dividida em cinco fases:

1- Conscientização: o consumidor toma consciência da existência do produto.

2- Interesse: o consumidor potencial se interessa e busca informações do produto.

3- Avaliação: o consumidor avalia o risco e o custo da experimentação.

4- Experimentação: o consumidor experimenta o produto e avalia se vai comprá-lo.

5- Adoção: o produto é adotado, se aprovado pelo consumidor.

A busca por novos materiais e processos de produção interligados aos princípios da sustentabilidade é evidente e indispensável. O designer, durante seu processo de desenvolvimento, pode projetar materiais que produzam o mínimo possível de rejeitos e permitam fechar o ciclo de vida de toda a matéria e energia utilizadas nos processos produtivos por meio da análise do ciclo de vida dos produtos. 
A transformação da pele de peixe em couro ecológico, respeitando o equilíbrio ambiental, surge como nova alternativa de material para atender o design sustentável. É possível entender que as possibilidades de aplicação do couro de peixe, associadas à preservação ambiental e à geração de benefícios socioeconômicos, se enquadram de maneira viável na oferta desse tipo de produto, apresentando ao consumidor novas possibilidades e probabilidade alta de aprovação - e, assim, contribuindo para que seu ciclo de vida seja extenso.

O couro de peixe é considerado um subproduto, o que faz dele um problema para o produtor ou para o abatedouro, pois, de acordo com Contreras-Guzmán (1994), a pele perfaz, em média, $7,5 \%$ do peso dos peixes teleósteos ${ }^{3}$. Muitas vezes, essa pele é moída juntamente com vísceras e restos de carcaças do próprio animal, sendo fornecida como fonte alimentar para animais.

A elaboração do couro a partir das peles residuais da filetagem de pescados representa uma fonte alternativa de renda que pode servir de matéria-prima para a fabricação de artefatos têxteis. Quando transformado em substrato têxtil, passa a ser benéfico à sociedade como um todo e ao meio ambiente.

Das 100 mil toneladas de pescado beneficiado por ano para exportação ou consumo interno na Amazônia, 7 mil são peles. Ciente desse fato, o engenheiro de pesca Nilson de Aguiar, coordenador do projeto INPA, decidiu buscar essa aplicação nobre para as sobras, aumentando o valor de um recurso biológico existente em grande quantidade nessa região (ADEODATO, 1995).

O couro de peixe é um produto nobre e de alta qualidade, possuindo a resistência como característica peculiar. Além dessa característica, para as espécies de peixes com escamas, as lamélulas de proteção na inserção da escama (ALMEIDA, 1998) resultam, após o curtimento, em um couro de aspecto típico e difícil de ser imitado, garantindo exclusiva padronagem de alto impacto visual (ADEODATO, 1995).

Muitos designers já defendem campanhas em que se pode observar o repúdio ao uso de outros couros, oriundos de raposas, chinchilas, ursos, bovinos, répteis, entre outros. Tratase de couros obtidos por processos muito cruéis, dolorosos e prejudiciais ao equilíbrio do meio ambiente. Alguns dos animais citados não fazem parte da fauna brasileira, mas são criados e reproduzidos em cativeiros, no Brasil, somente para este fim.

O mercado da moda tem se tornado o principal cliente do couro de peixe,

\footnotetext{
${ }^{3}$ Subclasse de peixes que compreende quase todas as formas inteiramente ossificadas.
} 
reconhecendo-lhe o valor e a importância. A imagem do couro de peixe neste mercado vem ganhando cada vez mais credibilidade e gerando conscientização. Acredita-se que é possível produzir produtos de couro conservando-se a qualidade e a beleza, sem o sacrifício de animais.

A importância dada ao uso de matérias-primas alternativas, com o apelo do "politicamente correto", torna a atividade econômica do curtume de couro de peixe inovadora e altamente promissora.

Porém, essa prática ainda é pouco funcional no que diz respeito ao beneficiamento têxtil do produto. Utilizam-se beneficiamentos têxteis químicos, altamente prejudiciais e que demandam gastos excessivos de água. Os tingimentos das peças também são feitos com corantes químicos. O reaproveitamento passa a ser só uma etapa evolutiva dentro desse processo de produção.

As possíveis alternativas encontradas para essa questão são a utilização de beneficiamentos têxteis sustentáveis tanto no processo do curtume quanto no tingimento.

Existem algumas aldeias de pescadores e comércios de produção de carne de peixe que tomaram a iniciativa de reaproveitar esse couro. O couro é recolhido e passa por um processo de beneficiamento têxtil, que possibilita sua conservação e o transforma em um objeto durável e resistente - tem o dobro da resistência do couro bovino.

A resistência do couro é influenciada por fatores como a espécie do peixe, sua idade e peso, sentido da pele (transversal ou longitudinal em relação ao comprimento do peixe), conservação e processo de curtimento (NUPÉLIA, 2014).

O mercado têxtil já reconhece o valor e a importância do uso do couro de peixe na fabricação de acessórios como bolsas, cintos, carteiras e sapatos. Muitos designers e estilistas já produzem e confeccionam esse couro, incluindo-o em suas coleções e atraindo a atenção dos consumidores. Pode ser utilizado em peças do vestuário, assim como nos acessórios. A produção é viável e permite criações em muitos setores, além da área têxtil.

Algumas ONGs (organizações não governamentais) brasileiras aproveitaram a descoberta da utilização do couro de peixe e atualmente vêm trabalhando com grupos, geralmente formados por mulheres de regiões ribeirinhas, que antes não possuíam ocupação e, assim, não participavam de nenhuma atividade produtiva. As trabalhadoras foram resgatadas de suas comunidades e, além de ocuparem o tempo antes ocioso, aprenderam a importância do reaproveitamento da pele do peixe, transformando-a em material utilizável. A maioria das ONGs (organizações não governamentais) trabalha com a pele de peixe aliada a outros 
elementos importantes, como, por exemplo, as fibras naturais de coco e buriti, produzindo produtos acabados e prontos para a venda. Deste modo, beneficiam o meio ambiente, trazendo novidades para o mercado têxtil e beneficiamento da comunidade produtora.

\subsection{Pesquisas realizadas no Brasil}

Ao longo do processo de pesquisa bibliográfica, de pesquisa de campo e do acompanhamento dos produtores, associações e ONGs que já trabalham com couro de peixe, observamos, de uma maneira mais específica e próxima, a realidade da inserção, da prática e da produção desse couro no Brasil.

Mediante o contato direto com essas empresas e por meio deste trabalho, é possível relatar como anda o desenvolvimento do produto e como cada órgão e cada instituição estão trabalhando.

Quando sé observado por uma vertente acadêmica, é possível notar poucas universidades que tratam do assunto - sempre á analisado por um prisma técnico e com uma visão voltada para a biologia, química e zoologia - como é o caso da Universidade Estadual de Maringá.

O Centro de Pesquisa Nupélia é líder quando o assunto é peixe. Existem muitas publicações de artigos nacionais e internacionais, journals e anais que falam do peixe, citando métodos de pesquisa - como observação da reprodução de variadas espécies em rios e mares -, acompanhamento do crescimento de ovos e larvas, aspectos ecológicos, a preservação das espécies e a dispersão dos cardumes em relação ao habitat natural deteriorado.

Em um primeiro momento, é difícil associar esses temas de pesquisa ao couro de peixe. Porém, quando aprofunda-se mais, observamos que as pesquisas feitas pelo núcleo são de extrema valia e influenciarão os resultados das pesquisas posteriores feitas com o couro de peixe.

Para chegar ao estágio de produção do couro, há que se levar em consideração as espécies que podem ser pescadas, com liberação regular para tal. É necessário verificar se sua pesca é legal, o habitat onde vivem e como ocorre seu processo de criação.

O Instituto Nacional de Pesquisa Amazônica, INPA, mantém um núcleo de pesquisa voltado para a observação da produção de couro de peixe amazônico. O núcleo é voltado para a pesquisa de couro somente dos peixes oriundos da região amazônica.

Dentre os membros compositores da equipe, podemos citar o pesquisador Nilson 
Carvalho, coordenador do projeto, e o técnico em curtimento José Jorge Rebello, que possui experiência de mais de 50 anos em curtimento de couros em geral.

Por falta de verba governamental, o projeto foi cancelado e encontra-se atualmente parado, aguardando providências (INPA, 2014).

Em toda a pesquisa realizada, que visa mapear a realidade nacional da produção do couro de peixe, optou-se por observar uma associação que desenvolve todo a produção do couro de peixe, desde o momento de obtenção das peles até o acabamento do produto final.

\subsubsection{INPA}

Criado em 1952 e implementado em 1954, o Instituto Nacional de Pesquisas da Amazônia (INPA) vem, ao longo dos anos, realizando estudos científicos do meio físico e das condições de vida da região amazônica para promover o bem-estar humano e o desenvolvimento socioeconômico regional. Atualmente, o INPA é referência mundial em biologia tropical (INPA, 2014).

Os primeiros anos do INPA foram caracterizados por pesquisas, levantamentos e inventários de fauna e de flora. Hoje, o desafio é expandir de forma sustentável o uso dos recursos naturais da Amazônia.

Para cumprir o desafio, o Instituto possui as coordenações gerais de Capacitação, Administração, Ações Estratégicas e Extensão. Possui também quatro coordenações de pesquisas atuando nos seguintes focos: Dinâmica Ambiental, Sociedade, Ambiente e Saúde; Tecnologia e Inovação; Biodiversidade.

O INPA ainda possui três núcleos de pesquisa localizados nos Estados do Acre, Roraima e Rondônia.

A sede do INPA ocupa $379.868,41 \mathrm{~m}^{2}$ e está localizada na área urbana de Manaus, distribuída em três campi:

-Campus Aleixo I, com 255.736,49m²;

-Campus Aleixo II, com 49.131,92 $\mathrm{m}^{2}$;

-Campus do V-8, com 75.000,00m².

Três reservas florestais e duas biológicas, quatro estações experimentais, duas bases flutuantes de pesquisa, um laboratório flutuante e um barco de pesquisa também compõem sua estrutura, conforme segue abaixo: 
Reservas:

1. Adolpho Ducke - Manaus;

2. Walter Egler - Rio Preto da Eva;

3. Ouro Preto d'Oeste - Rondônia;

4. Biológica da Campina - Manaus;

5. Biológica do Cuieiras - Manaus.

Estações Experimentais:

Em Manaus:

1. Silvicultura tropical;

2. Fruticultura;

3. Hortaliças (olericultura);

4. Agricultura de várzea.

Bases Flutuantes de Pesquisas:

1. Catalão, no Encontro das Águas;

2. Tarumã, no Rio Negro.

Laboratório Flutuante:

Herald Sioli, na Ilha da Marchantaria.

Barco de Pesquisas:

\section{http://www.inpa.gov.br/}

Amanaí II.

Sua missão é gerar, disseminar conhecimentos, tecnologia e capacitar recursos humanos para o desenvolvimento da Amazônia. 
Ao longo de seis décadas, vem assumindo responsabilidade crescente na tarefa de produzir conhecimento, estabelecendo um compromisso com o desenvolvimento sustentável, a defesa do meio ambiente e de seus ecossistemas, expandindo os estudos sobre a biodiversidade, a sociodiversidade, os recursos florestais e hídricos.

http://www.inpa.gov.br/

\subsubsection{Nupélia}

Núcleo de pesquisas em Limnologia ${ }^{4}$, Ictiologia ${ }^{5}$ e Aquicultura ${ }^{6}$.

A Nupélia concentra-se nas seguintes áreas de pesquisa:

\section{Botânica}

\section{Sistemática Vegetal}

\section{$\underline{\text { Ecologia }}$}

\section{Ecologia Aplicada}

Ecologia Numérica

Estatística Pesqueira

\section{Educação Ambiental}

\section{Ictiologia}

Ecologia de Comunidades

Ecologia Energética

Ecologia Reprodutiva

Ecologia Trófica

Ecomorfologia

Estudos de Idade e Crescimento

Ictiologia de Ictioplâncton

\footnotetext{
${ }^{4}$ Estudo científico das extensões de água doce com respeito a suas condições ou aspectos biológicos, químicos, físicos, meteorológicos, geológicos ou ecológicos.

${ }^{5}$ Ramo da zoologia devotado ao estudo dos peixes.

${ }^{6}$ Tratamento do ambiente aquático para criação de peixes, mariscos, entre outros. Destinado também ao cultivo de produtos naturais.
} 


\section{Limnologia}

Ecologia de Fitoplânction

Ecologia de Macroinvertebrados

Ecologia de Macrófitas Aquáticas

Ecologia de Perifiton

Ecologia de Zoobentos

Ecologia de Zooplâncton

Limnologia Básica

\section{Genética}

\section{Citogenética de Peixes}

\section{Genética Molecular de Peixes}

\section{Polimorfismo Enzimático de Peixes}

\section{Zoologia}

\section{Parisitologia de Peixes}

\section{Taxinomia de Peixes}

\section{http://www.nupelia.uem.br/}

\subsection{Cuidados especiais com a matéria-prima}

De acordo com Lopes (2010), aquicultura é o processo de produção em cativeiro, ou seja, em condições controladas, de organismos que vivem em ambiente predominantemente aquático.

A aquicultura é uma atividade praticada pelo ser humano há milhares de anos. Existem registros de que os chineses já tinham conhecimentos sobre essas técnicas há muitos séculos e de que os egípcios criavam a espécie conhecida como tilápia há cerca de quatro mil anos.

A aquicultura envolve a produção de peixes, camarões, rãs, ostras e outras espécies 
com o objetivo de servirem como alimento. Quando se fala especificamente de produção de peixes, essa atividade caracteriza-se como um subtipo da aquicultura denominado piscicultura. Em curtas palavras, piscicultura é a criação de peixes e se enquadra como uma especialidade da aquicultura.

Outro conceito importante é o da pesca. Esta é a extração de organismos aquáticos e seu produto é chamado de pescado. Contudo, todo peixe é considerado pescado, mas nem todo pescado é peixe, podendo ser crustáceo, molusco, anfíbio, quelônio e mamífero de água doce ou salgada.

De acordo com o Manual de Criação de Peixes (2014), inicia-se a piscicultura com a avaliação de um local para o criadouro. Após isso, é necessária a escolha das espécies que serão cultivadas. São relevantes alguns aspectos, tais como: adaptação da espécie, qualidade da água, nível de oxigênio, acidez, entre outros. Precisa de autorização governamental de órgãos como IBAMA e o Ministério Público, salvo se for local destinado à pesca esportiva, como pesque-pague ou pesque-solta.

Depois de escolhido o local, devidamente autorizado pelo governo, deve-se escolher a melhor espécie de alevinos (filhotes de peixe), de boa procedência. A partir disso, com um bom manejo, aplicando-se as técnicas de reprodução, e nutrição, obtém-se alta qualidade produtiva e, consequentemente, bom retorno financeiro.

O criadouro ou viveiro da piscicultura pode ser um reservatório escavado em local natural, onde haja sistemas de abastecimento e de drenagem da água, a fim de o tanque ser enchido ou esvaziado em curtos intervalos de tempo.

O tanque tem sua estrutura parecida com a do viveiro; é revestido com alvenaria de pedra ou tijolo em concreto. Na piscicultura são usados diversos tanques, dependendo da sua finalidade (manutenção de reprodutores, preparo de reprodutores, acasalamento, criação de pós-larvas e de alevinos, engorda, entre outros).

Os viveiros são classificados em dois tipos:

- Viveiro de barragem - é construído no fundo de um vale, onde corre curso de água em córrego ou olho d’água, mediante o crescimento de uma pequena barragem ou dique.

- Viveiro de derivação - escavado ou elevado no terreno natural, é abastecido por água de nascente, de uma represa ou açude, por meio de um sifão, galeria etc. A água é conduzida por canais abertos ou turbilados, ou até mesmo por bombeamento através de curso de água ou reservatório, dando controle de entrada e saída de água.

A água deve ser de qualidade. É importante verificar a sua temperatura, pois isso 
influencia na reprodução e no crescimento do pescado. Temperaturas muito baixas ou elevadas atingem negativamente a alimentação dos peixes. Mede-se usando um termômetro de imersão com escala de 0 a $50^{\circ} \mathrm{C}$. A água do fundo é tirada por um frasco com tampa, que é destampado quando atinge a profundidade desejada. É preciso levá-lo depressa para a superfície e a temperatura da água no interior, medida.

Quanto mais transparente a água, maior será a penetração da luz, essencial para os seres produtores de matéria orgânica, os fitoplânctons, bactérias fotossintéticas e macrófitas aquáticas, todos os organismos que dependem da luminosidade para fazer fotossíntese. As águas claras são as melhores para abastecer os tanques, levemente azuladas ou esverdeadas. Com um instrumento chamado disco de SECCHI é possível medir a transparência da água.

Amarra-se o disco com um "cabo de náilon de 3/16", que deve ser mergulhado até que não seja mais visto. Por meio do cabo, faz-se a medição da profundidade, e a transparência da água dos viveiros deve ser menor do que $30 \mathrm{~cm}$.

A quantidade necessária para encher o criadouro é diretamente proporcional à capacidade de acumulação, calculada com base em sua área e profundidade média. Por exemplo, quando ele possui área de um hectare e profundidade média de um metro, deve-se enchê-lo com 10 mil metros cúbicos de água, em intervalos de, no máximo, 72 horas. Depois de cheio, só se coloca água para compensar as perdas por evaporação ou percolação.

Quando der início à construção do tanque, é necessário conhecer o pH, dureza; alcalinidade e teores de nitrogênio, fósforo, potássio, cálcio, sódio, magnésio, enxofre, ferro e alumínio. No caso do ferro e alumínio em alta escala no terreno, construir viveiros para piscicultura se torna uma ação não recomendável.

Um terreno argiloso é vantajoso devido à capacidade de impenetrabilidade do solo, bem como dos minerais produzidos por ela. Os arenosos, por sua vez, não são viáveis por não reterem a água, além de sua pobreza mineral. Entretanto, é interessante a construção de viveiros de derivação. Por outro lado, em terrenos pedregosos não é aconselhável.

A profundidade deve ser um pouco maior que dois metros e é importante estudar a área em que será construída a bacia de peixes. A topografia do local vai indicar os aspectos para a construção, como: o número de tanques, tipo de viveiros, se é barragem ou derivação, se há possibilidade da construção, bem como a forma do tanque.

As peles chegam ao curtume congeladas ou salgadas. As preocupações básicas referem-se à qualidade intrínseca das peles e à conservação. Quanto à qualidade, é necessário observar a procedência, a qualidade da extração, tipos de espécies e o tamanho. A procedência 
é importante porque caracteriza um bom fornecedor não só com referência à qualidade como também quanto à garantia de fornecimento e preços justos (NUPÉLIA, 2014).

A qualidade da extração está correlacionada diretamente à qualidade do produto, porque peles bem extraídas significam cortes uniformes, ausência de furos e boa conservação. As espécies trabalhadas estão correlacionadas ao tipo de mercado e/ou de produto que se deseja. Também existem espécies que possuem peles mais indicadas para curtimento do que outras, como, por exemplo, o surubim (ou pintado), que tem peles muito bonitas. Porém, ainda não há uma tecnologia suficientemente desenvolvida para assegurar e manter essa beleza.

Quanto ao tamanho das peles, há que ajustá-lo de acordo com os equipamentos e as demandas de mercado. Por exemplo, peles muito pequenas são mais difíceis de comercializar.

As peles estão sujeitas à ação de substâncias denominadas enzimas, oriundas da própria pele ou produzidas por bactérias decompositoras, quando expostas a temperaturas superiores a $7{ }^{\circ} \mathrm{C}$. Essas enzimas iniciam e promovem a degradação das peles, e os procedimentos que interrompem tal ação são as técnicas de conservação.

A conservação pode ser efetuada por diversos processos, com destaque para a salga e o congelamento. Ambos devem ser efetuados imediatamente após a extração. Ao chegarem ao curtume, as peles devem permanecer conservadas até o início do processo de curtimento mediante alguns cuidados, como, por exemplo, peles congeladas têm de ser mantidas congeladas, peles salgadas terão espaço próprio com umidade controlada, sobretudo em regiões de umidade relativamente alta. Nessas regiões, é preferível adotar a conservação por congelamento, desde que isso não signifique elevação de custos e a conservação verificar-se por curtos espaços de tempo.

As peles também podem ser conservadas mediante processos de desidratação por solventes e de secagem, desde que, novamente, para curtos espaços de tempos.

A finalidade da conservação é interromper as causas que favorecem a decomposição das peles, de modo a conservá-las nas melhores condições possíveis até o início dos processos que irão transformá-las, pelo curtimento, em material estável e imputrescível. Pelo processo de salga, o sal extrai água, reduzindo o seu teor para 35\% a 40\%, extrai proteínas (albuminas e globulinas) e inibe a ação das enzimas (NUPÉLIA, 2014).

A ação conservante do sal depende das especificações seguintes:

Concentração: o teor de cloreto de sódio no sal deverá ser de 98 a 99\%; 
Impurezas: mínimas;

Quantidade: 40 a 50\% de sal em relação à massa de peles;

Granulometria: sal com grãos muito grandes ou muito pequenos pode ocasionar defeitos.

O tamanho do grão deverá estar compreendido entre 1 e $3 \mathrm{~mm}$. Com sal muito fino, a dissolução pode ser muito rápida e poderá escorrer como salmoura; com sal muito grosso, poderá ocorrer formação de marcas, depressões e cavidades - e, além disso, o sal muito grosso tem mais dificuldade de penetrar no centro das peles.

As peles salgadas devem ser armazenadas em locais frescos, ventilados moderadamente e sem correntes de ar, protegidos dos raios solares diretos, com piso impermeável e sem escoamento que possibilite a conservação de água e o seu gotejamento sobre os couros.

As boas condições de armazenamento são obtidas com temperaturas entre 7 e $10{ }^{\circ} \mathrm{C}$ e umidade relativa do local entre 85 e $90 \%$.

\subsection{Beneficiamento têxtil do couro de peixe}

\subsubsection{Operações de curtimento}

\subsubsection{Remolho}

O remolho tem por finalidade repor, no menor espaço de tempo possível, o teor de água apresentado pela pele quando ela ainda recobria o animal, recuperando a sua hidratação. Esse processo limpa as peles, eliminando impurezas aderidas a ela, e extrai as proteínas e materiais interfibrilares.

Essa operação deve ser convenientemente conduzida, pois interrompe a conservação, favorecendo o desenvolvimento bacteriano e a atividade enzimática. A importância do remolho reside principalmente no fato de a água atuar como veículo dos produtos químicos nas etapas posteriores, levando-os a entrar em contato com as fibras da pele.

\subsubsection{Caleiro}

Esta operação é utilizada para provocar as seguintes ações:

- Ação sobre o colágeno e outras proteínas; 
- Abertura da estrutura fibrosa;

- Intumescência da estrutura fibrosa;

- Ação sobre a gordura.

O sistema mais utilizado é o sistema cal-sulfeto. O hidróxido de cálcio atua como fonte de álcali e é utilizado por conta de sua baixa solubilidade, que evita valores muito altos de concentração de íons hidroxila. A adição de sulfeto de sódio aumenta a alcalinidade e seu efeito sobre o colágeno.

A rotação do fulão deve ser de 4 RPM, sendo que uma rotação excessiva pode causar danos à pele. Durante a calagem ${ }^{7}$, a temperatura do banho deve situar-se na faixa entre 18 e 25 ${ }^{\circ} \mathrm{C}$. Temperaturas superiores a $40{ }^{\circ} \mathrm{C}$ causam pronunciada hidrólise da substância dérmica, conduzindo a couros superficiais e fracos.

\subsubsection{Operações mecânicas pós caleiro}

- Descarne

Consiste em raspar o lado da carne da pele, visando a remoção de restos de gorduras e carnes. É feita mecanicamente, com a raspagem da pele por rolo de facas helicoidais.

\section{- Divisão}

Consiste em separar a pele em duas metades com espessuras adequadas ao trabalho que será desenvolvido quando o couro estiver pronto.

- Extração de gorduras

Das operações de descarne e divisão resulta um resíduo sólido composto de proteínas e gorduras de alto valor comercial.

Esse resíduo é tratado sob temperaturas (vapor de água) que dissolvem as gorduras, permitindo-se a obtenção de dois componentes: gordura animal - contendo ácido esteárico, ácido palmítico, ácido oleico, entre outros.; proteína animal - basicamente transformada em farinha de carne e utilizada como componente de ração animal (CENTRO DO COURO, 2013).

Igualmente, todas essas operações foram realizadas com maior ou menor intensidade com todas as peles de peixes trabalhadas. A operação de "divisão" somente foi utilizada para diferentes espécies de bagres.

\footnotetext{
${ }^{7}$ Ação ou efeito de aplicação da cal.
} 


\subsubsection{Desencalagem}

\section{a) Tradicional}

$\mathrm{Na}$ desencalagem são utilizadas substâncias químicas que reagem com a cal, dando origem a compostos de grande solubilidade e facilmente removíveis por lavagem, visando a eliminação das substâncias alcalinas, tanto aquelas que se encontram depositadas quanto as quimicamente combinadas.

$\mathrm{Na}$ desencalagem são usados sais amoniacais, como cloreto de amônio e sulfato de amônio, e sais ácidos, sendo o bissulfito de sódio o mais utilizado. Deste modo, formam a solução tampão com seus sais. O uso de ácidos na desencalagem limita-se aos ácidos orgânicos, como os ácidos lático, fórmico e butílico (CENTRO DO COURO, 2013).

Os agentes desencalantes podem ser utilizados isoladamente ou em mistura. É comum a utilização de uma mistura de sulfato de amônio, cloreto de amônio e ácido sulfoftálico na proporção de 4:3:3 partes, respectivamente.

A desencalagem é feita, normalmente, com pequenos volumes de água (70\% em peso das peles) a uma temperatura entre 30 e $37^{\circ} \mathrm{C}$ e pH de 7 a 9, dependendo do processo. A operação é controlada, na prática, colocando-se algumas gotas de solução alcoólica de fenolftaleína sobre a pele (causa reação incolor em algumas peles e rosada em outras).

\subsubsection{Píquel}

No píquel, as peles desencaladas e purgadas são tratadas com soluções salino-ácidas que visam preparar as fibras colágenas para uma fácil penetração dos agentes curtentes.

O banho de piquelagem, via de regra, é composto por 30 a 100\% de água, 4 a $10 \%$ de cloreto de sódio e 1,0 a 1,5\% de ácido sulfúrico, todos em relação ao peso das peles. Ao se executar a piquelagem, as peles devem ser previamente tratadas com solução salina com concentração mínima de 5 B. Após cerca de 10 minutos é adicionado o ácido sulfúrico, diluído na proporção 1:10. Em alguns processos de piquelagem pode-se acrescentar ácido fórmico ou formiato de cálcio antes do ácido sulfúrico, na proporção de 0,5 a 1,0\% em relação ao peso das peles. Para se obter uma flor mais fechada, também podem ser adicionados sais de alumínio na proporção de 0,5 a $1,0 \%$ em relação ao peso das peles - após completado o tempo de ação do ácido sulfúrico.

Deve-se observar que a operação de piquelagem varia de acordo com o tipo de pele, pois depende da espessura, resistência e da ação mecânica. 
O píquel deve ser realizado em temperatura variando entre 20 e $25^{\circ} \mathrm{C}$.

Abaixo de $20{ }^{\circ} \mathrm{C}$ a hidrólise e peptização são insignificantes, mesmo para períodos longos. Acima de $30^{\circ} \mathrm{C}$ essas reações são bastante acentuadas, mesmo em períodos curtos. $\mathrm{O}$ píquel realizado a temperaturas superiores a $30^{\circ} \mathrm{C}$ resultará em couro fracos, sem resistência ao rasgamento.

\subsubsection{Curtimento}

A operação de curtimento consiste na transformação da pele em material estável não deteriorável. O curtimento é realizado pela reação entre o colágeno da pele e produtos químicos curtentes inorgânicos, como sais de cromo, zircônio e derivados.

De acordo com a CETESB - Companhia de tecnologia de saneamento ambiental (2005), o curtimento é um processo que consiste na transformação das peles, pré-tratadas na ribeira, em materiais estáveis e imputrescíveis, ou seja, a transformação das peles em couros. Pode ser classificado em três tipos principais: mineral, vegetal e sintético. Normalmente, também é realizado em fulões.

Ao longo do processo de curtimento mineral, o cromo ainda é o principal composto utilizado mundialmente, tanto pelo tempo relativamente curto de processo como pela qualidade que confere aos couros em suas principais aplicações. A fonte de cromo mais utilizada é o sulfato básico de cromo, em que o cromo se encontra no estado trivalente. No entanto, esforços crescentes para sua substituição são verificados, devido ao impacto ambiental potencialmente negativo. Este curtimento pode ser realizado no mesmo banho do píquel ou formulado em banho novo, de forma separada.

O processo de curtimento vegetal é geralmente utilizado para a produção de solas e de alguns tipos especiais de couro, bem como em combinação com os outros tipos de curtimento. Devido ao seu alto custo, os taninos são utilizados o máximo possível - na maioria das vezes, faz-se apenas a reposição de solução para o lote de peles seguinte, para compensar a parte absorvida pelas peles do lote anterior. Com o aumento do uso de materiais sintéticos na fabricação de solas, o curtimento vegetal de couro para este fim diminuiu significativamente.

Durante o processo de curtimento sintético são empregados curtentes, em geral orgânicos (resinas, taninos sintéticos, entre outros), que proporcionam um curtimento mais uniforme e aumentam a penetração de outros curtentes, como os taninos e de outros produtos. Isso propicia, por exemplo, um melhor tingimento posterior. Geralmente, são mais caros do que outros curtentes e mais usados como auxiliares de curtimento.

a) com sais de cromo 
O curtimento ao óxido de cromo é realizado com as peles em estado piquelado. Com a incorporação às peles de 2,5 a 5,0\% de cromo, elas transformam-se em couros de elevada estabilidade hidrotérmica.

\section{b) clássico}

Neste processo, as peles devem ser previamente piqueladas em pH 2,5 a 3,0 . O cromo é adicionado no mesmo banho do píquel ou em banho novo. O banho poderá ter a seguinte composição: 30 a $50 \%$ de água, sal para 2,5 a 3,0\% de $\mathrm{Cr}^{2} \mathrm{O}^{3}$ - todos em peso. $\mathrm{O}$ curtimento inicia-se em baixo valor de $\mathrm{pH}$, para facilitar a penetração do curtente, devendo ser gradualmente elevado a um pH de 3,8 a 4,0 pela adição de agentes basificantes, tais como bicarbonato de sódio, acetato de sódio, carbonato de sódio, óxido de alumínio, entre outros. A adição do basificante só deverá ser iniciada após haver segurança absoluta da penetração do cromo no couro.

Valores excessivamente elevados de $\mathrm{pH}$ podem ocasionar flor solta e áspera; valores baixos de pH conduzem a couros vazios. Em cada tipo de curtimento e para cada tipo de pele é necessário determinar o pH de trabalho mais adequado. Quando a reação se completar, o couro será considerado curtido e deverá sofrer retração quando mergulhado em água fervente por 1 a 3 minutos, não devendo manter o mesmo toque inicial.

Com o aumento da temperatura verifica-se maior e mais rápida absorção dos sais de cromo, podendo-se, dentro de determinados limites, diminuir o tempo de curtimento. A temperatura de curtimento não deverá ultrapassar $35^{\circ} \mathrm{C}$ nas primeiras cinco horas de processo, e depois ser elevada gradativamente até atingir $45^{\circ} \mathrm{C}$ no final do trabalho.

\subsubsection{Operações de pós-curtimento}

Uma vez concluído o curtimento do couro ao cromo, é necessário prepará-lo para a operação de neutralização.

Assim, o couro deve ser espremido em máquina de rolo, que retira o excesso de água, facilitando as outras operações.

Logo em seguida é feita a qualificação quantitativa. Nesse estágio, cada peça é relacionado a artigos definidos, em função dos seus defeitos naturais.

A seguir é feito o rebaixamento em máquinas especiais, quando os couros são rebaixados, agrupados por peso e, em seguida, direcionados à neutralização (CENTRO DO COURO, 2013). 


\subsubsection{Neutralização}

A neutralização consiste na eliminação dos ácidos livres existentes nos couros de curtimento mineral ou formados durante o armazenamento. $\mathrm{O} \mathrm{pH}$ da superfície do couro é elevado para a faixa de 4,6 a 5,2 ou, no caso de vestuário, para a faixa de 5,2 a 5,7.

Os principais agentes de neutralização são: bicarbonato de sódio - que deve ser dissolvido a temperaturas inferiores a $35^{\circ} \mathrm{C}$-, carbonato de sódio, bicarbonato de amônia, sulfato de sódio, formiato de sódio, formiato de cálcio, acetato de sódio, entre outros.

Após a neutralização, é preciso efetuar a lavagem dos couros, com a finalidade de se eliminar o excesso de sais. A não remoção desses sais pode causar alterações no couro acabado, como, por exemplo, a eflorescência salina sobre a flor ou a distribuição desuniforme dos produtos subsequentes.

A lavagem pode ser contínua ou com tampa fechada em banho com 200 a 300\% de água em peso, temperatura de 30 a $40{ }^{\circ} \mathrm{C}$, durante 5 a 10 minutos.

O controle de neutralização deve ser feito pela medida do $\mathrm{pH}$ e pela cor do corte do couro, com indicador de verde bromo cresol.

\subsubsection{Tratamento de efluentes líquidos}

\subsubsection{Descrição dos sistemas de tratamento}

Adotada a segregação de despejos anteriormente citada, verifica-se que o sistema de tratamento de efluentes líquidos será subdividido em três unidades que atuam em paralelo: a unidade de reciclagem de banhos de depilação e caleiro, a unidade de reciclagem de banhos de curtimento e o tratamento dos demais banhos gerados no processo produtivo.

\subsubsection{Unidade de reciclagem dos banhos residuais de curtimento}

Os banhos residuais de curtimento são segregados dos demais banhos por meio de uma canaleta individualizada que recolhe o banho em frente ao fulão. Na unidade de reciclagem o banho passa primeiramente por um peneiramento e, logo após, é armazenado em um tanque de coleta e precipitação. Nesse tanque o banho é mantido sob agitação mecânica para facilitar o ajuste de $\mathrm{pH}$ com álcali em aproximadamente 8,3, a fim de precipitar o cromo na forma de hidróxido de cromo $3-\mathrm{Cr}(\mathrm{OH})_{3}$.

O efluente é bombeado do tanque de coleta e precipitação para um decantador, onde 
ocorre a separação do precipitado de hidróxido de cromo. O líquido sobrenadante do decantador é enviado para a ETE - Estação de Tratamento de Efluentes. O precipitado é recolhido em um tanque para redissolução com ácido sulfúrico. O licor de cromo formado é armazenado em um tanque separado para posterior reutilização no processo produtivo (CENTRO DO COURO, 2013).

\subsubsection{Unidade de reciclagem dos banhos residuais e caleiro}

O banho residual de depilação e caleiro é segregado dos demais por meio de uma canaleta individual que o recolhe em frente ao fulão. Ele então segue, por gravidade, para a unidade de reciclagem, onde passa por uma caixa de gordura e é armazenado em um tanque de coleta. No tanque de coleta o banho é mantido sob agitação mecânica, sem introdução do ar, para manter os sólidos presentes em suspensão e ao mesmo tempo minimizar a possibilidade de oxidação do sulfeto residual, cuja manutenção da concentração verificada no banho residual é importante ao retornar ao processo produtivo.

Uma peneira instalada antes do decantador promove a separação dos resíduos sólidos grosseiros do banho.

No decantador ocorre a sedimentação natural dos resíduos decantáveis, os quais, extraídos pelo fundo da unidade, constituem o lodo do caleiro, que segue para disposição final em leitos de secagem, podendo ser incorporado sem maiores problemas à lavoura, desde que tal procedimento seja acompanhado por técnicos capacitados.

Ocorre que, durante sua desidratação em leitos de secagem, há paralelamente certa estabilização da matéria orgânica em meio alcalino, que futuramente irá favorecer sua aplicação na lavoura sobretudo como condicionante de solo, já que é fonte de nitrogênio e fósforo. Contudo, face à presença de íons $\mathrm{Na}+$, a disposição final sistemática em solos para fins agrícolas deverá ser acompanhada por engenheiros agrônomos, a fim de se evitar a saturação dos solos por disposição indevida e ocasionar uma diminuição de sua produtividade (CENTRO DO COURO, 2013).

Cabe destacar que o resíduo aqui considerado não apresenta riscos de contaminação tóxica superiores àqueles advindos da aplicação de fontes de NPK comerciais, tanto dos solos quanto dos lençóis freáticos das áreas em que esse resíduo for aplicado.

A fase sobrenadante do decantador segue para um tanque de estocagem, e daí será tomada uma amostra para determinação das quantidades de insumos a se adicionar (no caso, teores de sulfeto e cálcio, entre outros), visando a obtenção de um banho similar ao primeiro. 
Reformulando o banho, ele é, então, bombeado ao fulão a fim de ser reutilizado.

É importante que, na canaleta de coleta, para o banho a ser segregado para a unidade de tratamento/reciclo, seja previsto um sistema de comporta que possibilite o descarte dos banhos de lavagem para o sistema de tratamento principal, pois estes não são passíveis de reutilização, por conta das concentrações muito reduzidas em sulfeto, se comparadas aos volumes das lavagens, que inviabilizam economicamente sua reutilização.

\subsubsection{Tratamento físico-químico ou primário}

Os demais banhos, provenientes do processo industrial e das limpezas de pisos, máquinas e equipamentos, seguem por gravidade por uma canaleta geral com destino às primeiras unidades de tratamentos. Nessa canaleta, em local de fácil acesso para limpeza, será colocada uma grade para promover a remoção preliminar dos resíduos sólidos mais grosseiros.

A seguir, deve-se adotar uma caixa de gordura, para que uma parcela da gordura sobrenadante seja removida do sistema, ocorrendo posteriormente um peneiramento cuja finalidade é a remoção dos sólidos que tenham passado pelo gradeamento.

Após o peneiramento, as águas seguem por gravidade para o tanque de equalização. Esse tanque será responsável pela homogeneização dos diversos banhos e, a partir dele, há vazão constante de efluentes ao longo do dia para as unidades subsequentes e também para oxidação do residual de sulfetos oriundo das lavagens dos banhos residuais. Para tanto, o tanque de homogeneização é dotado de um sistema de agitação e aeração. Esse sistema fornece ar suficiente para homogeneizar os diversos banhos, oxidar o sulfeto residual e manter os sólidos presentes em suspensão, minimizando a formação de depósitos no fundo do tanque, com a consequente formação de maus odores.

Para catalisar a oxidação de sulfetos pela ação do oxigênio do ar fornecido ao meio pelos aeradores, será adicionada solução de sulfato de manganês, em uma dosagem de $20 \mathrm{mg}$ de $\mathrm{Mn++}$ por litro de efluente bruto.

Do tanque de homogeneização, o líquido será bombeado para as demais unidades do sistema físico-químico. Por meio dessa bomba ter-se-á condições de manutenção de uma vazão constante de líquido. A bomba adotada leva cerca de 13 a 20 horas para bombear todo o conteúdo do tanque. Junto à tubulação de recalque, em um local de fácil acesso e manipulação, está previsto um dispositivo para ajuste fino de vazão (CENTRO DO COURO, 2013). 
Após a homogeneização e oxidação complementar, o líquido bombeado do tanque chegará com a vazão desejada, previamente ajustada ao tanque de $\mathrm{pH}$. Neste tanque, o efluente deverá permanecer em mistura por um período compreendido entre 5 e 10 minutos. A sonda eletrolítica de um peagâmetro irá monitorar o $\mathrm{pH}$ do líquido, procurando mantê-lo dentro de um padrão pré-estabelecido pelos técnicos operadores da unidade. Para esse ajuste fino, o peagâmetro estará ligado a duas bombas dosadoras individuais, capazes de dosar álcali e ácido, conforme a necessidade.

O líquido escoa, por gravidade, do ajuste de pH para o tanque de coagulação, no qual será efetuada a adição de coagulante (via de regra, sulfato de alumínio). A dosagem de coagulante será efetuada por meio de bomba dosadora, de acordo com a dosagem previamente indicada. Esse tanque, provido de agitação mecânica rápida, é onde o líquido deverá permanecer ou misturar-se por um período compreendido entre 5 a 10 minutos, sendo, portanto, das mesmas dimensões do tanque de ajuste do $\mathrm{pH}$.

Ainda por gravidade, o efluente coagulado escoará para o tanque de floculação. Nesse tanque, com tempo de retenção hidráulica ligeiramente superior ao dos dois anteriores (de 8 a 15 minutos), será efetuada a adição de polieletrólito, com a finalidade de se aumentar a densidade dos flocos formados na coagulação e, consequentemente, aumentar a velocidade de sedimentação. A dosagem será efetuada por meio de bomba dosadora, que pode ser a mesma que dosa a solução de coagulante. O tanque de floculação será provido de um misturador lento a fim de se evitar a quebra de flocos de lodo já formados.

Do tanque de floculação, o efluente escoará por gravidade para a unidade de sedimentação. Nessa unidade o efluente encontrará condições propícias para a sedimentação e segregação do material sedimentado (lodo primário) e do clarificado, que irá alimentar o sistema de tratamento biológico. O sedimentador adotado é do tipo Dortmund, cilindro tronco cônico. O tempo de retenção será de 2 a 3 horas, conforme a vazão de tratamento adotada.

Após a sedimentação primária têm-se duas linhas distintas: o material sedimentado (lodo primário) e o que se denomina efluente primário (clarificado).

O lodo é bombeado para um tanque de acondicionamento próprio à desidratação desse material em leitos de secagem.

Após a desidratação, o lodo será removido manualmente e transportado para a célula correspondente da unidade de disposição e tratamento de resíduos sólidos ou usado para aproveitamento agrícola, conforme deliberação do órgão de controle ambiental.

O efluente clarificado escoa por gravidade ao tratamento biológico, que será do tipo 
lagoa aerada facultativa em série, seguida de uma lagoa facultativa de polimento.

\subsubsection{Tratamento biológico ou secundário}

O sistema adotado será do tipo lagoa aerada facultativa, mecanicamente, por meio de aerador de superfície. Nessa lagoa, devido às condições de operação, às características do despejo em tratamento e às condições climatológicas, pode haver o desenvolvimento de um fino floco biológico e de algas microscópicas. Por isso, após a lagoa, não está descartada a possibilidade de se adotar um sedimentador secundário, a fim de se evitar um arraste excessivo de sólidos juntamente com o efluente final (CENTRO DO COURO, 2013).

O sedimentador secundário, caso necessário, será similar ao sedimentador primário, do tipo Dortmund, cilindro-tronco, cônico, respeitada a taxa de aplicação compatível com a velocidade de sedimentação dos flocos biológicos. O lodo biológico sedimentado será bombeado para o tanque de homogeneização do tratamento físico-químico.

O clarificado escoa por gravidade do sedimentador para o corpo receptor.

É indicada a instalação de medidores de vazão na entrada do sistema biológico (canaleta de acesso do efluente primário) e um medidor de vazão no efluente da lagoa facultativa de polimento, antes da descarga no corpo receptor.

Caso a empresa não tenha interesse econômico de reutilizar um desses banhos, a existência de unidades separadas possibilita a segregação de parcela com significativo potencial poluidor dos demais banhos.

Tal fato torna-se claro quando se analisa especificamente o caso dos banhos de curtimento. Sabe-se que o cromo é eliminado de efluentes líquidos por precipitação, deste modo o lodo sedimentado irá possuir altos teores de cromo. Com a segregação do banho de curtimento, mesmo que não se vise a reutilização no processo produtivo, evita-se a contaminação de todo o iodo primário com altos teores de cromo, como o que se verifica caso essa separação não seja efetuada e os banhos com cromo residual sejam tratados no tratamento principal.

Assim, o iodo que irá conter uma elevada concentração de cromo estará reduzido a pequeno volume. Na prática, essa segregação funcionará como se houvesse um tratamento específico para as águas do processo de curtimento.

Entende-se por demais banhos as lavagens, a descalcinação e o líquido proveniente das operações realizadas em máquinas e lavagem de pisos e equipamentos. 


\subsubsection{Tingimento}

O tingimento de tecidos é uma arte milenar e a disponibilidade comercial de corantes é enorme. A tecnologia moderna do tingimento consiste em várias etapas.

Os tipos de corantes são escolhidos de acordo com a natureza da fibra têxtil. Características estruturais, classificação e disponibilidade são aspectos que devem levados em conta quando se deseja delimitar o corante o mais adequado para o tipo de aplicação, assim como suas propriedades de fixação, que devem ser compatíveis com o material a ser tingido, considerações econômicas e outros.

Segundo Guaratini e Zanoni, o tingimento é um processo químico da modificação da cor da fibra têxtil por meio da aplicação de matérias coloridas, disponíveis em solução.

O processo pode sofrer variações de acordo com a fibra têxtil. Para cada tipo de fibra existe um corante específico.

No processo de tingimento ocorre uma modificação físico-química, em que o substrato têxtil forma uma luz refletida que provoca uma percepção de cor. Os produtos que provocam modificações são denominados corantes, que são compostos orgânicos capazes de colorir o substrato têxtil de forma que a cor seja relativamente sólida à luz e a tratamentos úmidos.

Durante o processo de tingimento três etapas são consideradas importantes: o tingimento, a fixação e o tratamento final. A fixação que colore a fibra é feita por meio de reações químicas reativas da simples insolubilização do corante e de derivados gerados, e ocorre usualmente em diferentes etapas durante a fase de coloração e fixação.

Os artigos têxteis devem ser cuidadosamente preparados. Antes de se iniciar o tingimento, eles passam por um processo inicial chamado de preparação e pré-tratamento, cujo objetivo é eliminar todas as impurezas do tecido. Tais impurezas podem ser ceras, óleos lubrificantes, parafinas, gomas, entre outros. São de origem natural ou artificial.

\subsubsection{INPA desenvolve corante ecologicamente correto}

Uma técnica ecologicamente correta. É assim que pode ser definido o processo para tingir o couro de matrinxã a partir de corantes naturais, os extraídos de duas plantas amazônicas: o cacauí e o crajiru. O processo não faz uso de produtos químicos, não causa mal à saúde nem ao meio ambiente, e pode ser reproduzido por comunidades ribeirinhas.

A pesquisa é o resultado do trabalho de mestrado "Extração e Uso de Corantes 
Vegetais da Amazônia no Tingimento do Couro de Matrinxã”, realizado por Karina Suzana Gomes de Melo. O projeto foi orientado pela cientista da Coordenação de Pesquisas em Tecnologia de Alimentos (CPTA) Jerusa de Souza Andrade, em co-orientação do Professor Dr. Rogério Souza de Jesus, do Instituto Nacional de Pesquisas da Amazônia (INPA).

O projeto teve duração de dois anos e foi financiado pela Coordenação de Aperfeiçoamento de Pessoal de Nível Superior (CAPES) e pela Fundação de Amparo à Pesquisa do Estado do Amazonas (Fapeam).

Durante as pesquisas, Melo buscou combinar tecnologias com a disponibilidade de matérias-primas para o desenvolvimento de processos simples e de fácil execução. A ideia era gerar produtos com potencial de mercado, por isso, o uso do couro de peixe tingido com plantas da região. "Essa junção serve de base para políticas públicas de desenvolvimento sustentável da Amazônia”, ressalta.

Para se chegar às duas plantas, o cacauí e o crajiru, Melo explica que foram realizados diversos testes com cascas, flores, sementes e folhas, de forma aleatória, sem critério de produção ou disponibilidade. Os critérios adotados para aprovação nos testes foram: proporção dos pigmentos e solubilidade em água.

De acordo com a pesquisadora, foram coletadas 15 amostras e todas passaram por análises laboratoriais para se determinar o grupo cromógeno (antocianinas, flavonoides, carotenoides, pigmentos solúveis em água), ou seja, o objetivo era verificar os pigmentos presentes e quantificá-los. O procedimento foi adotado para se saber qual a quantidade necessária de matéria-prima para se tingir o couro do peixe (dar pigmento).

"Por ser uma técnica pioneira, não havia informações científicas e técnicas [a respeito]. Na literatura não consta nenhum outro trabalho que tenha utilizado corante natural e que a matéria-prima não fosse comestível”, afirma. Segundo Melo, a mangarataia e o jenipapo também podem ser utilizados no tingimento, contudo, o objetivo era utilizar produtos não comestíveis.

No início das análises, a escolha das fontes de pigmentos para o teste de tingimento teve por base a quantidade de antocianinas - cacauí - e de pigmentos solúveis em água crajiru. Por serem amostras purificadas e conhecidas, os corantes artificiais utilizados no tingimento de couro oferecem uma base da quantidade que pode ser utilizada, a qual varia em função da intensidade da cor desejada.

Já os corantes naturais selecionados para a pesquisa não foram purificados e, por não se saber a quantidade de corante naturais utilizada no tingimento do couro de peixe, foram 
feitos vários testes para se conhecer qual a porcentagem $(5 \%, 10 \%$ ou $15 \%)$ do corante ideal em relação ao peso do couro para o tingimento. Com esse experimento foi possível avaliar as diferenças na tonalidade, na uniformidade de cobertura e na resistência aos fatores degradantes da cor. Os melhores resultados foram obtidos com as maiores proporções das amostras de crajiru e cacauí desidratadas.

$\mathrm{O}$ processo envolveu a dissolução dos corantes em água morna $\left(40{ }^{\circ} \mathrm{C}\right) . \mathrm{O}$ material ficava em repouso durante 24 horas. Após esse período, era colocado o ácido e o material descansava por mais 2 horas, a fim de se fixar o pigmento. O processo foi repetido nas três concentrações: $5 \%, 10 \%$ e $15 \%$. Os melhores resultados foram obtidos nas concentrações de $10 \%$ e $15 \%$.

Após o tingimento foram feitos outros testes, como o de lavabilidade e o de resistência à luz fluorescente e à luz solar. Nos testes com a luz fluorescente não houve perda da coloração. O mesmo não aconteceu com a luz solar.

Durante sete dias, das $8 \mathrm{~h}$ às $16 \mathrm{~h}$, os couros tingidos com crajiru e cacauí ficaram expostos à luz do sol. Melo explica que, visivelmente, ambos perderam coloração, mas não do ponto de vista estatístico. Ou seja, em análises no aparelho denominado "colorímetro digital", foi verificado que os pigmentos perdidos pelos couros estavam dentro de um quadrante aceitável de tonalidade.

"O couro tingido com crajiru e cacauí, quando receberam a aplicação da laca à base d'água, apresentaram variação de tonalidade; o couro tingido com crajiru ficou mais escuro, enquanto o com cacauí, mais claro", afirma Melo, acrescentando que, para aumentar a durabilidade, dar brilho e resistência ao material, a "laca" - verniz obtido sinteticamente - é fundamental.

“O corante de crajiru apresentou maior resistência à ação da luz e da água, apresentando coloração que variou do vermelho-púrpura ao vinho, enquanto o de cacauí foi do lilás claro ao escuro. O que obteve o melhor resultado na coloração foi o de crajiru", destaca.

\subsection{Distribuição no mercado têxtil e de confecção}

De acordo com Soares (2013), O Departamento de Ciências Domésticas DCD/UFRPE, em parceria com o Departamento de Pesca e Aquicultura - UAST e com 
Departamento de Biologia/Ecologia - UFRPE, tem desenvolvido nos últimos anos um projeto de extensão de gestão de resíduos da atividade pesqueira com pesquisa, planejamento e elaboração de oficinas de design de peças com couro e escamas de peixe em comunidades pesqueiras, visando, ainda, o aprimoramento da técnica, melhoria da qualidade do produto e a elevação da renda do grupo por meio do projeto - Plano de Gestão de Resíduo da Atividade Pesqueira com Ênfase em Concha e Escama.

As atividades de extensão da área de Arte, Habitação e Vestuário do DCD, incluem ainda outro projeto de extensão, que em parceria com artesãos/ãs do município de Paudalho/PE. A proposta consiste na troca de experiências na criação de uma coleção de moda que visa aprimorar as técnicas locais da comunidade, melhorar a qualidade de seus produtos e consequentemente melhorar a renda familiar. Alguns resultados deste trabalho foram apresentados na Feira Nacional de Negócios do Artesanato - FENEART 2013.

Trabalhando dentro da temática do projeto - Uso de Resíduos Domésticos e Industriais no Artesanato Pernambucano, uma coleção de moda, composta por vestuário e acessórios, foi desenvolvida de modo a unir a renda Tenerife a materiais residuais em diversas atividades. Desta temática surgiu a possibilidade de inserir peças na linha de acessórios de moda na coleção trabalhada a partir do resíduo da atividade pesqueira resultantes do projeto com resíduo de pescado.

A construção do tema para o desfile TeneArte/UFRPE foi de forma participativa entre alunas, professoras e artesãos/ãs de Paudalho envolvidos/as no projeto de resíduos domésticos e industriais. Inspirado na fauna brasileira, o tema escolhido foi intitulado de "Realeza", propondo como inspiração a majestade e imponência encontradas nos animais do Brasil. Por ser um material nobre, a renda sugere luxo e riqueza, estas remetem à nobreza encontrada também na postura de muitos animais.

Como Shulte (2008) afirma, a natureza inspira muitas coleções de moda e sua relação com esta, para além da inspiração temática, tem se voltado para o âmbito do respeito e da consideração pelo meio ambiente. Falar sobre natureza é também abrir caminhos para a necessidade eminente do surgimento de uma conscientização relacionada ao desenvolvimento sustentável. Citando conteúdos da Declaração do Rio de Janeiro (Eco92) sobre o meio ambiente e desenvolvimento, tem-se como primeiro princípio: os seres humanos estão no centro das preocupações com o desenvolvimento sustentável e têm direito a uma vida saudável e produtiva, em harmonia com a natureza.

Os acessórios de moda com o resíduo da atividade pesqueira foram selecionados e planejados de modo a harmonizarem com as peças de vestuário sem concorrer com o destaque 
da coleção, a renda Tenerife. Este fato constituiu num desafio, uma vez que tanto as rendas como o couro e as escamas possuem uma beleza estética singular que atraem a atenção de quem os aprecia.

Além da realização deste trabalho, algumas marcas já influentes no mercado de moda brasileiro trabalham com a sustentabilidade e o design alinhados. Algumas das mais conhecidas serão apresentadas nos próximos parágrafos.

\subsubsection{Osklen}

Marca criada por Oskar Metsavaht no ano de 1989 em Ipanema, Rio de Janeiro. É vista como uma marca casual, que mescla urbano e natureza, global e local, orgânico e tecnológico com sofisticação. A Osklen tem hoje 41 lojas no Brasil, duas lojas em Milão, uma em Nova York, uma em Miami, uma em Tóquio e uma em Roma, além de showroom na Itália, França, Espanha, Grécia e Portugal. Exporta também para Bélgica, Chile e Oriente Médio. A Osklen tem utilizado em suas coleções o couro de peixe para a confecção de bolsas, sapatos, tênis, mochilas e sandálias.

Oskar Metsavaht também criou o "Instituto E”, que é uma associação privada civil sem fins lucrativos, sediada no Rio de Janeiro, voltada para a promoção da vocação do Brasil como "país do desenvolvimento sustentável”. O e-fabrics é um projeto que foi lançado em janeiro de 2007 durante a São Paulo Fashion Week. Tem a missão de contribuir com a moda brasileira pelo mundo, associando à sua sensualidade e criatividade o valor das principais riquezas e singularidades do país, dentre elas a biodiversidade e suas tradições culturais. Tudo isso mediante pesquisas e disponibilizando-se as informações para o mercado.

Figura 56: Calçados produzidos com couro de peixe.
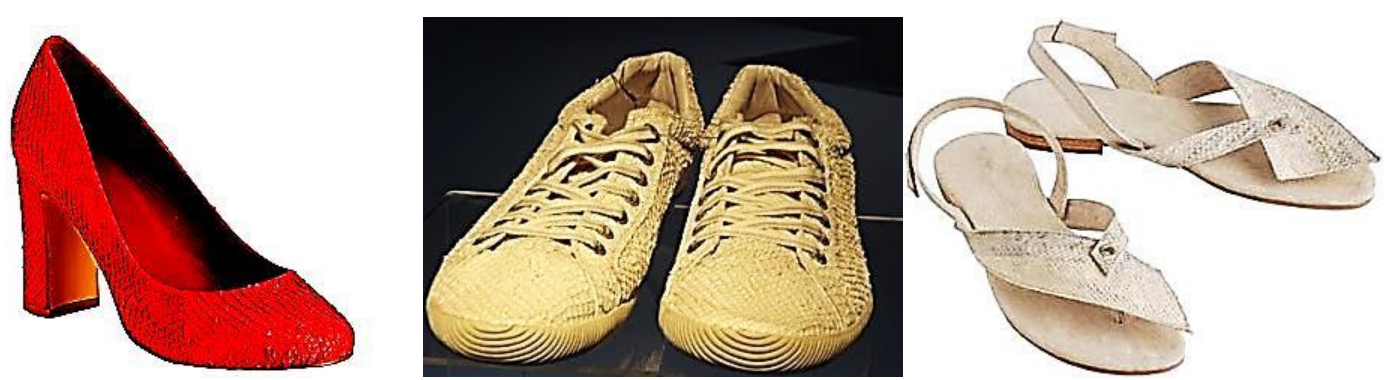

Fonte: <http://osklen.com/>, acesso em 11 jan. 2014, às 07h12.

\subsubsection{Mad Maria}

Empresa localizada em Londrina, no interior do estado do Paraná. Trabalha com toda a 
cadeia produtiva do peixe, desde o alevino produzido, passando pelo abate no frigorífico, até a confecção de bolsas e acessórios.

O conceito da empresa Mad Maria é de que não basta apenas criar bolsas com qualidade. A moda, o couro de peixe, a beleza, seu conceito envolve mais do que isso: a marca é artesanal, consciente e ativa por um mundo melhor.

Figura 57: Bolsa feita com couro de peixe

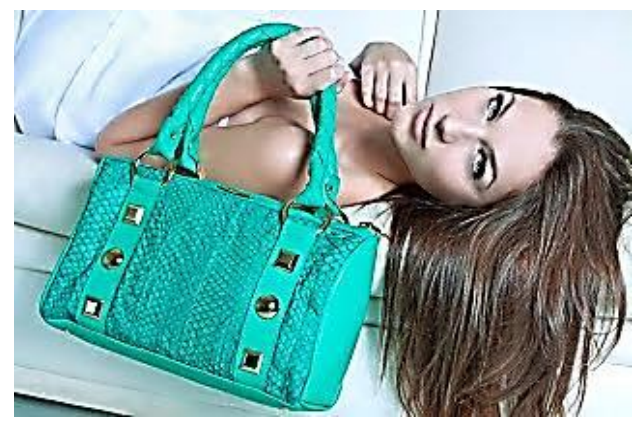

Fonte: <http://courodepeixe.blogspot.com.br/2011/11/mad-maria.html >, acesso em 11 jan. 2014, às 09h47.

\subsubsection{Nova Kaeru}

A Nova Kaeru é um curtume de couros exóticos. Fabrica couros de peixes, avestruzes e jacarés. Sua produção baseia-se em processos naturais ("exotic Bio Leathers").

Situa-se no distrito de Bemposta, na bela região serrana do Estado do Rio de Janeiro. Sua estrutura de ponta não tem paralelo no setor de couros exóticos brasileiros. A Nova Kaeru oferece produção em escala industrial, mas com acabamento artesanal.

Sua vocação são os produtos inovadores, que buscam na tecnologia, sustentabilidade e preservação do meio ambiente a inspiração para uma vida melhor. Esses valores estão refletidos em todos os processos e produtos da empresa.

Pioneiros em curtir couros orgânicos, a empresa desenvolveu um novo método de curtimento, utilizando insumos isentos de metais pesados, especialmente cromo.

Seus produtos são orgulhosamente chamados "Bio Leather" ("chrome free"), que é como a empresa se autoclassifica.

Os destaques são o "Processo Kaeru^”, exclusivo e patenteado, que permite fabricar mantas "sem costura", e o curtimento toque suave ("soft touch"), especialmente eficaz no amaciamento da osteoderme de jacarés, dando a esse couro maciez e maleabilidade inigualáveis. 


\section{História}

$\mathrm{Na}$ década de 90, o diretor técnico, Eduardo Filgueiras, iniciou seus estudos e pesquisas em laboratório para o desenvolvimento de novas técnicas de curtimento e soldagem de couros, já visando a criação de mantas de peles soldadas, produto sem similar no mundo.

Tendo iniciado com peles de rãs e pequenos peixes em caráter artesanal, em 2006 a empresa dos primeiros anos transformou-se no principal curtume de peles exóticas da América do Sul, a Nova Kaeru, mantendo o necessário toque artesanal em uma estrutura industrial para curtimento e soldagem, com reaproveitamento de água, estação de tratamento e dando emprego direto a mais de 40 pessoas em uma região essencialmente rural.

A empresa é licenciada pela FEEMA $^{8}$ e por todos os órgãos que se ocupam das boas práticas ambientais.

Figura 58: Pirarucu (à esq.), salmão (centro) e pescado (à dir.).

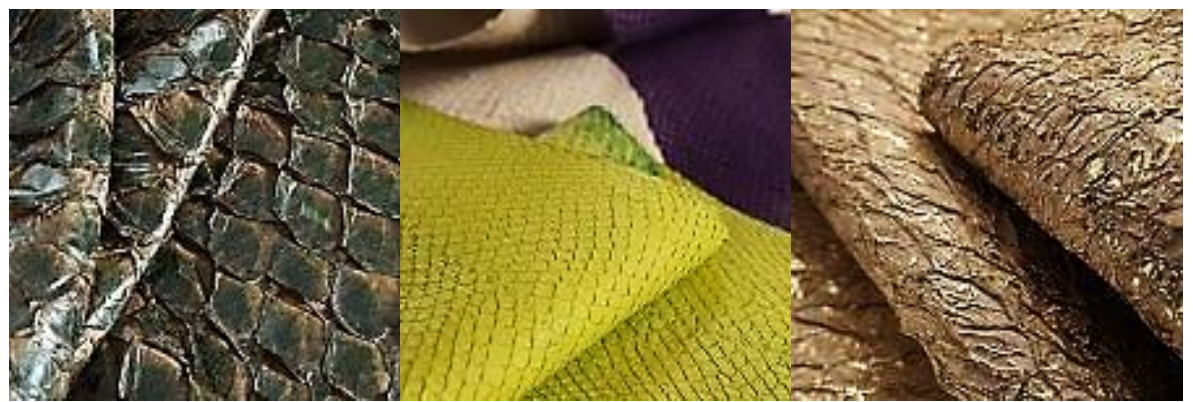

Fonte: <http://novakaeru.com.br/pt-br/>, acesso em 12 jan. 2014, às $19 \mathrm{~h} 14$.

${ }^{8}$ Fundação Estadual de Engenharia do Meio Ambiente. 


\section{ONGS, INSTITUIÇÕES E COOPERATIVAS}

De acordo com Pinto (2012), no Brasil, o terceiro setor vem se expandindo cada vez mais, com ligações religiosas, educacionais, ambientais e outras. Na década de 1970 surgiu o neoliberalismo, que considerava apenas igrejas, orfanatos, escolas religiosas e hospitais, organizações importantes sem fins lucrativos. Essas entidades vêm mostrando cada vez mais força de vontade de crescer por intermédio dessas organizações, e do neoliberalismo proporcionou-lhes uma grande conquista de liberdade no mercado para que as famílias conquistassem seu espaço. O país foi vivenciando mudanças a partir de movimentos sociais e sindicais, buscou soluções de problemas como falta de água, falta de terra, aumento de preços, dentre outros. Já na década de 1990, depois de muitas lutas pelos direitos civis, a força que usavam na expressão "sem fins lucrativos" deixou de existir e deu-se início a uma nova origem ao terceiro setor, as ONGs, que por sua vez têm uma responsabilidade de crescer junto às fundações, associações, clubes recreativos e esportivos, institutos, entre outros.

Por movimentarem recursos públicos e privados, essas organizações têm como garantia as informações úteis e confiáveis para monitoramento dos recursos e a avaliação dos recursos sociais, e essa informação coletada serve para que recebam repasses de verbas do governo.

Assim, cabe destacar que essas entidades ficaram sob responsabilidade de órgãos públicos, que repassam as verbas mediante assinatura do contrato de gestão com o poder público. As entidades prestadoras de serviços à coletividade - ONGs sem fins lucrativos - por lei têm que estar enquadradas e autorizadas a funcionar legalmente para obter os recursos governamentais, dentre eles a isenção ou a não incidência de tributos, podendo usufruir de benefícios fiscais.

Define-se terceiro setor, segundo Aquino Alves, pesquisador da Fundação Getúlio Vargas, citado por Melo Neto e Froes (2001, p.9), como o espaço institucional que abriga ações de caráter privado, associativo e voluntarista voltadas para a geração de bens de consumo coletivo, sem que haja qualquer tipo de apropriação particular de excedentes econômicos gerados nesse processo.

Atualmente, é possível encontrar facilmente algumas ONGs, associações, cooperativas e afins que trabalham efetivamente com o couro de peixe. Muitas delas fazem desta prática sua principal fonte de renda e, em alguns casos, apresentam cases de sucesso baseados na sua aposta de trabalho. 


\subsection{A pesca}

A pesca é uma das atividades tradicionais mais antigas da humanidade. A produção aquícola e pesqueira no mundo, segundo dados da $\mathrm{FAO}^{9}$ para o ano de 2008, foi da ordem de 115 milhões de toneladas de pescado, e o consumo médio per capita é de $17 \mathrm{~kg}$ ao ano. No Brasil, nos últimos oito anos, a produção nacional de pescado aumentou em 25\% e, em 2009, superou 1 milhão de toneladas, segundo o Ministério da Pesca e Aquicultura (MPA).

A preocupação com uma alimentação saudável e as mudanças no estilo de vida sugerem uma tendência de maior consumo de peixe no país. No Mato Grosso do Sul, a produção de pescado totalizou 17.354 toneladas em 2009 (MPA, 2009), das quais 4.850 toneladas se referem à pesca extrativista.

Segundo estudo da Embrapa (CATELLA, 2003), a pesca é a segunda atividade econômica de maior impacto no Pantanal (a primeira é a agropecuária) e gera cerca de $\mathrm{R} \$ 40$ milhões ao ano. A captura total anual de pescado é da ordem de 373 toneladas (2007). Os peixes mais comuns na região são os bagres e as principais espécies capturadas são pintado (Pseudoplatystoma corruscans), cachara (Pseudoplatystoma fasciatum) e pacu (Piaractus mesopotamicus). Em Corumbá, a captura de peixes somou 147 toneladas, das quais 43 toneladas por pescadores profissionais (que comercializaram apenas oito toneladas) e mais de 103 toneladas resultantes da pesca esportiva. Os pescadores observam a redução de estoques de alguns tipos de peixe, como o dourado (Salminus maxillosus), que é um dos mais valorizados pelos moradores locais e também pelos turistas.

\subsection{Amor-peixe}

A associação foi criada em 2003, em Corumbá, cidade situada às margens do Rio Paraguai, no coração do Pantanal. É um projeto de desenvolvimento sustentável que foi desenvolvido por um grupo de mulheres pantaneiras, com apoio do WWF-Brasil ${ }^{10}$, juntamente com parceiros locais. É um modelo de trabalho que conserva os recursos naturais e a qualidade ambiental, contribuindo para a preservação do Pantanal.

Amor-Peixe é um projeto exemplar de desenvolvimento sustentável. Os resultados

\footnotetext{
${ }^{9}$ Food and Agriculture Organization of The United Nations (Organização das Nações Unidas para a Alimentação e a Agricultura).

${ }^{10}$ Fundo Mundial para a Natureza: organização não governamental internacional que atua nas áreas da conservação, investigação e recuperação ambiental.
} 
alcançados de alívio da pobreza e emancipação social e econômica são palpáveis e impactam diretamente em um grupo de mulheres organizadas e sua comunidade ribeirinha, contribuindo para a conservação do Pantanal. Desenvolvido pelo WWF-Brasil, com um grupo de mulheres pantaneiras e com o apoio de parceiros locais, o projeto é um piloto e sua escala é pequena. Mas constitui um caso de sucesso e seu efeito é multiplicador, pois influencia as políticas públicas e a formação de outros grupos (WWF-BRASIL, 2014).

Entre as lições aprendidas, o destaque recai sobre a constatação de que a construção, para ser sólida, tem que ter um bom alicerce. O grande diferencial do projeto foi proporcionar o crescimento do grupo, em lugar de focar em lideranças. Isso significou formar a associação com base em objetivos comuns, valores coletivos e com um contrato social transparente, construído de forma participativa para selar um compromisso efetivo.

As mulheres que participaram do projeto tiveram a oportunidade de redesenhar seu destino e se fazer ouvir para ajudar a promover mudanças em prol de um futuro melhor para a sociedade. De mulheres simples, sem renda nem voz, restritas ao mundo do lar e que enfrentam a desigualdade de gênero, elas aprenderam a criar e se recriaram.

Hoje elas têm sua própria fonte de renda e decidem como usar seu dinheiro. Usam a internet, viajam de avião, discutem políticas com representantes setoriais, governamentais e científicos, são chamadas para palestrar.

Assumiram um papel de liderança e são influentes em casa, na comunidade e nos rumos da sociedade. Seu sucesso é reconhecido e serve de inspiração: elas são chamadas para falar de sua experiência e já capacitaram mais de dez grupos pelo país afora, além de ter assento em diversos fóruns de políticas públicas e participar de inúmeras feiras e eventos (WWF-BRASIL, 2014).

O projeto é fonte de inspiração e referência na região e no país, e poderá servir de modelo para novas ações de desenvolvimento sustentável e conservação ambiental.

O projeto Amor-Peixe teve uma estratégia desenhada com perspectiva de início, meio e fim e cumpriu todas as etapas: diagnóstico do problema, proposta de solução, identificação de parceiros, construção da confiança do grupo, desenvolvimento das habilidades necessárias para atingir os objetivos, fortalecimento da organização para promover sua emancipação, retorno periódico em campo para avaliação e monitoramento e planejamento de um futuro sem o WWF-Brasil. Foi esse apoio estratégico, técnico e financeiro do WWF-Brasil que fez a diferença para a Amor-Peixe. Com foco no desenvolvimento organizacional, em lugar de dar o peixe, o WWF-Brasil ensinou a pescar. 
Embora o WWF-Brasil tenha concentrado seu apoio ao projeto só na segunda fase, em menos de cinco anos de ações sistemáticas se obteve um raro nível de autonomia e sustentabilidade. O WWF-Brasil atuou como um berçário, ajudando a desenvolver todas as associadas sem perder o foco principal: o desenvolvimento organizacional. Cada uma encontrou seu lugar no grupo e assumiu um objetivo coletivo: produzir e comercializar artesanato com couro de peixe para gerar renda e, ao mesmo tempo, conservar o meio ambiente (WWF-BRASIL, 2014).

Hoje, a justa repartição do trabalho e dos benefícios são práticas consolidadas. Os resultados foram alcançados mediante pesquisas participativas, oficinas e assessoria de capacitação e desenvolvimento, bem como o monitoramento contínuo. O benefício é social, econômico, ambiental - e sustentável - e a Amor-Peixe tem todas as condições para se emancipar e continuar sua trajetória de sucesso. Ao identificar o momento de saída, o WWFBrasil promoveu, junto com a Amor-Peixe, uma avaliação do projeto e o planejamento do futuro e ajudou a construir uma aliança de parceiros. Os novos desafios incluem ampliar o número de associadas, ganhar escala de produção, utilizar insumos cada vez mais naturais e elevar o patamar de renda conquistado.

Quando o WWF-Brasil decidiu focar na associação Amor-Peixe, ela já estava criada oficialmente e tinha um estatuto registrado, o que ocorreu em 2003. O grupo se instalou em um barracão da Casa do Artesão - espaço cedido pela Prefeitura de Corumbá e que faz parte do roteiro de visita dos turistas. Com a aprovação de um projeto junto ao Fundo de Investimentos Culturais de Mato Grosso do Sul (FIC-MS), a associação conseguiu adquirir equipamentos básicos para iniciar sua produção: um freezer de 550 litros para estocar as peles de peixe; fulão (espécie de tambor ou caldeira) para processar $100 \mathrm{~kg}$ de pele; três máquinas de costura industriais (duas de costura reta e overloque e outra de zigue-zague) para confeccionar os produtos e um ferro de passar.

Nessa primeira fase, no entanto, a Amor-Peixe era apenas um agrupamento de indivíduos com projetos individuais. As mulheres se reuniam, mas não formavam realmente um coletivo. $\mathrm{O}$ artesanato era produzido e comercializado individualmente. $\mathrm{O}$ crescimento entre elas foi muito desigual e o destaque se restringiu à presidente da Amor-Peixe, Wânia Alecrim. A organização do grupo era precária e o artesanato que produziam era rudimentar. As diferenças e conflitos se intensificaram.

As mulheres estavam descontentes e sentiam-se despreparadas. Em 2006 a presidente da Amor-Peixe foi premiada pela revista Cláudia como Mulher Revelação na categoria Trabalho Social e pelo SEBRAE como Mulher Empreendedora. Esse reconhecimento, no 
entanto, não se refletiu na associação. Wânia Alecrim seguiu sua trajetória individual e deixou a associação. Sem liderança, o grupo ficou desnorteado e se desmobilizou, marcando o fim da primeira fase do projeto Amor-Peixe.

Além do WWF-Brasil, a associação Amor-Peixe recebeu apoios pontuais de várias organizações nessa primeira fase: Embrapa Pantanal, SEBRAE, Universidade Católica Dom Bosco - UCDB, Governo Municipal de Corumbá (por meio da Fundação de Cultura), Governo de Mato Grosso do Sul (por meio do Instituto do Meio Ambiente do Pantanal - Imap e do Instituto de Desenvolvimento Agrário e Extensão Rural - Idaterra) e do Governo Federal (por meio da Secretaria Especial de Aquicultura e Pesca - Seap e do IBAMA), além de SENAI/SESI, Colônia Z-1 e a Sociedade Caritativa e Humanitária, que foram parceiros do WWF-Brasil na primeira oficina de curtimento e aproveitamento do pescado.

A crise na Amor-Peixe, ocorrida em 2006, foi tão profunda que exigiu um processo de refundação da associação. A mudança iniciou-se em 2007 e este ano marcou o início do aprendizado em grupo para se organizar e definir seus próprios rumos. Passo a passo, com o apoio do WWF-Brasil, as mulheres construíram uma organização adequada aos seus desejos e objetivos.

Enquanto os demais parceiros atuaram sempre de forma pontual, o WWF-Brasil desempenhou um papel fundamental para que o grupo alcançasse uma real autonomia. Nessa segunda fase, a partir de uma abordagem sistêmica, integrada e com metodologias participativas, o WWF-Brasil atuou como um verdadeiro berçário, nutrindo a organização social para que ela pudesse se desenvolver com segurança e se tornar capaz de caminhar com suas próprias pernas. Ao longo de 2007, 2008 e 2009, o WWF-Brasil prestou uma assessoria intensa, em que a chave foi ensinar a aprender. Em 2010, a Amor-Peixe atingiu suficiente maturidade e o WWF-Brasil começou a planejar sua estratégia de saída, marcada para 2011.

Ao encerrar o projeto, deixou a Amor-Peixe assentada sobre sólido alicerce, com uma gestão empreendedora compartilhada e autonomia associativa. Nesse período, todo o trabalho de formação das integrantes da Amor-Peixe foi liderado pelo WWF-Brasil, por meio da bióloga e educadora ambiental Terezinha Martins, analista de conservação do Programa Cerrado Pantanal e do consultor Josenildo Souza e Silva, especialista em metodologias participativas - ele é engenheiro de pesca licenciado em Ciências Agrárias, mestre em administração e comunicação e doutor em agroecologia, sociologia e desenvolvimento sustentável e professor da Universidade Federal de Rondônia. Cláudia Ferraz Gomes também prestou uma consultoria de dois meses em 2008 para o aprimoramento de design e estilo (WWF-BRASIL, 2014). 
Figura 59: Raspagem das peças.

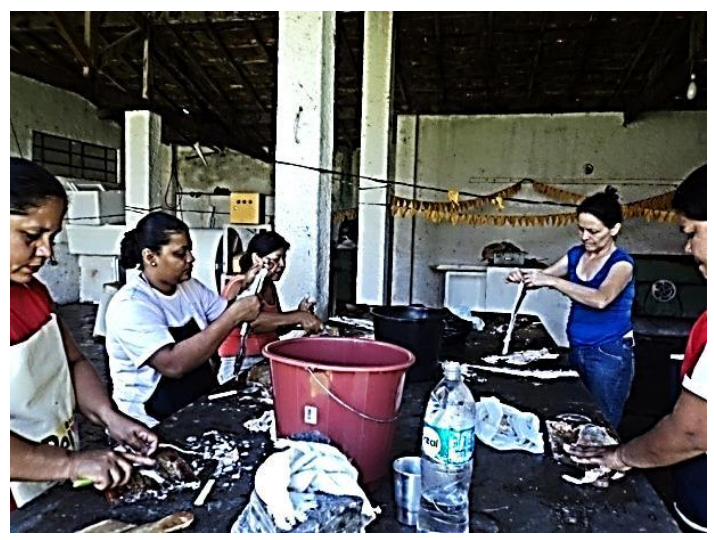

Fonte: <http:/ http:/www.wwf.org.br//>, acesso em 05 jan. 2014, às 15 h28.

Figura 60: Equipamento utilizado no processo de curtimento.

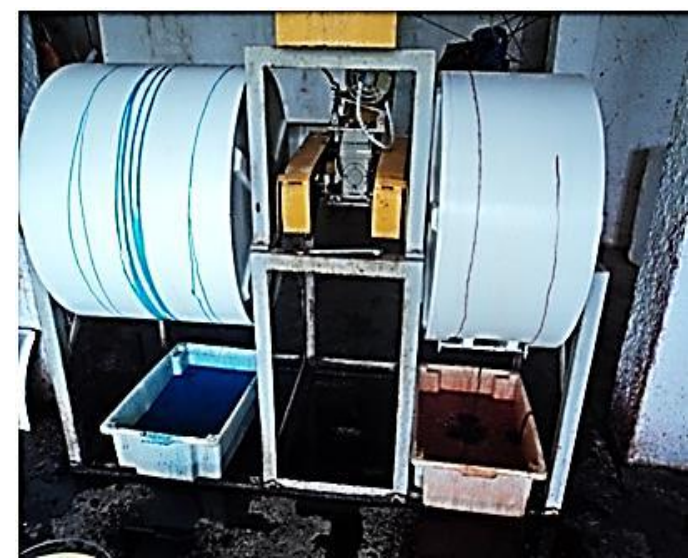

Fonte: <http:/ http:/www.wwf.org.br//>, acesso em 05 jan. 2014, às 16 h45.

Figura 61: Secagem das peles.

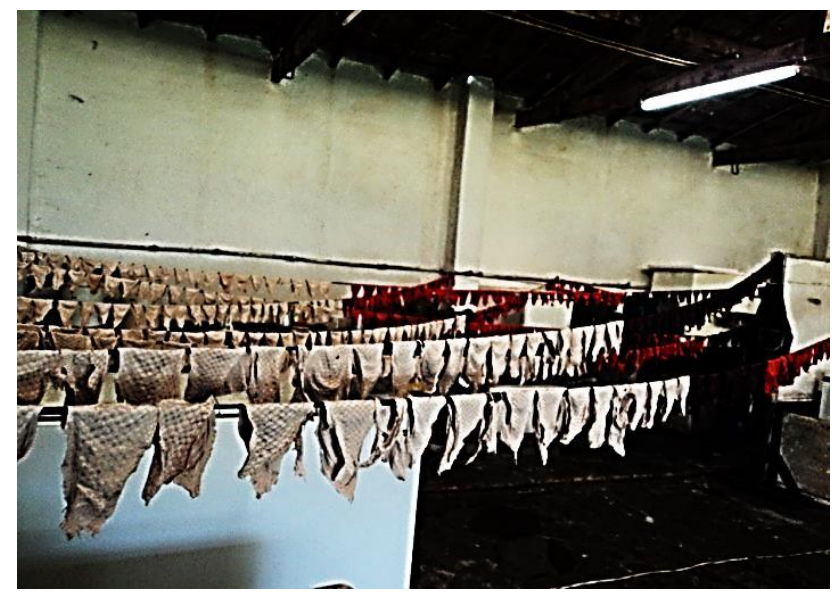

Fonte: <http:/ http:/www.wwf.org.br//>, acesso em 05 jan. 2014, às 18 h36.

Figura 62: Amaciamento manual das peles. 


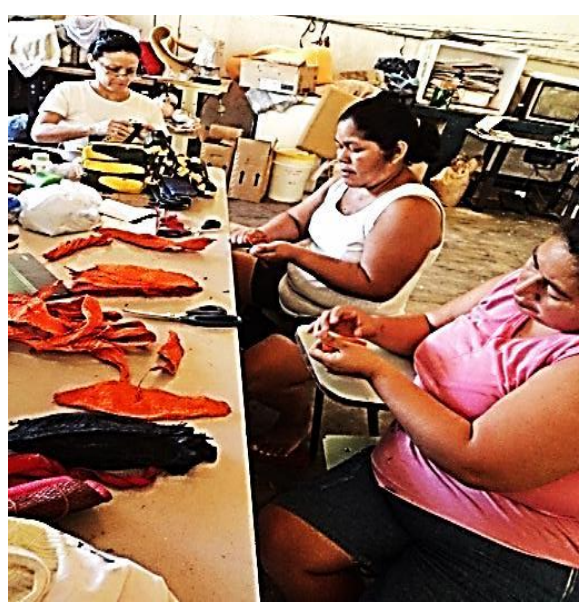

Fonte: <http:/ http:/www.wwf.org.br//>, acesso em 05 jan. 2014, às 19 h57.

Figura 63: Colagem das peças.

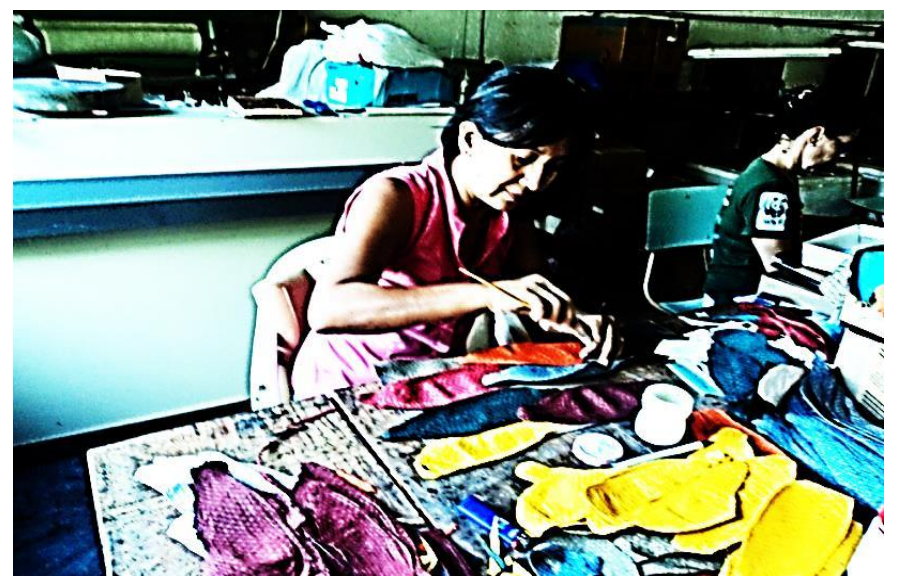

Fonte: <http:/ http:/www.wwf.org.br//>, acesso em 05 jan. 2014, às 20h49.

Figura 64: Montagem das peças.
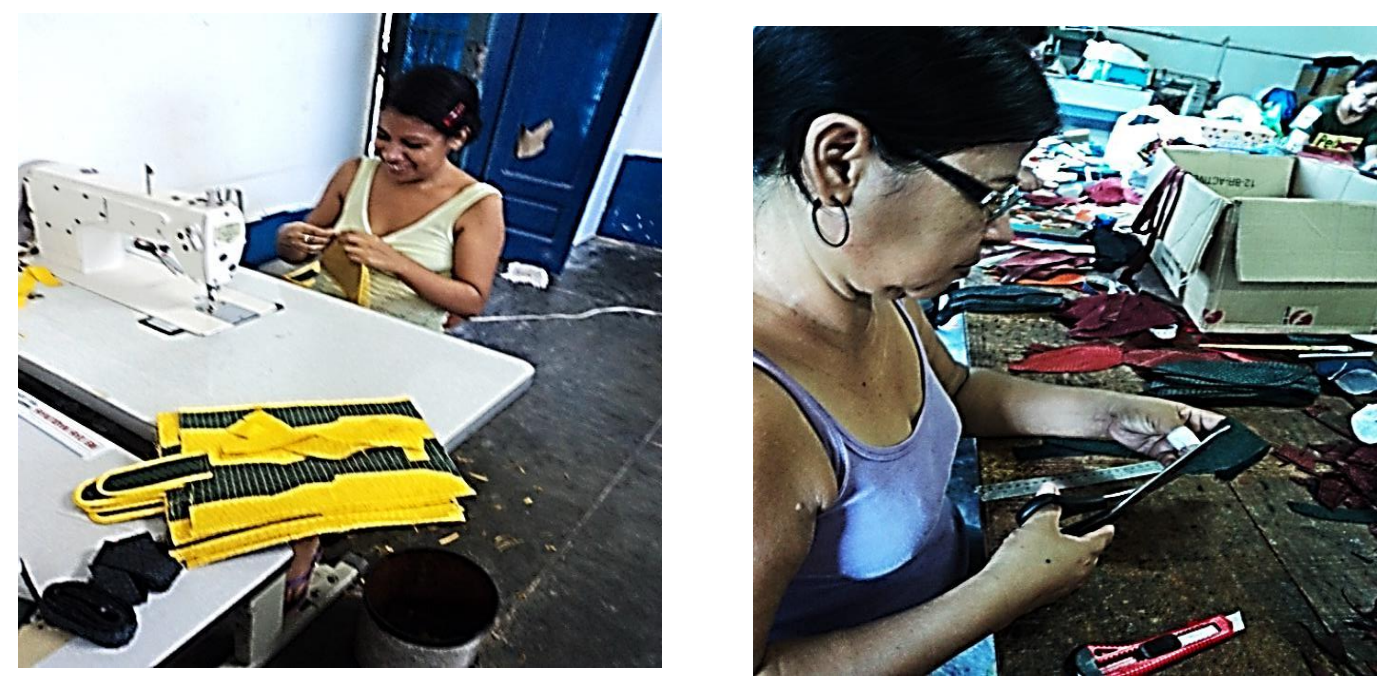

Fonte: <http:/ http:/www.wwf.org.br//>, acesso em 05 jan. 2014, às $21 \mathrm{~h} 13$.

Figura 65: Retoques finais e controle de qualidade. 


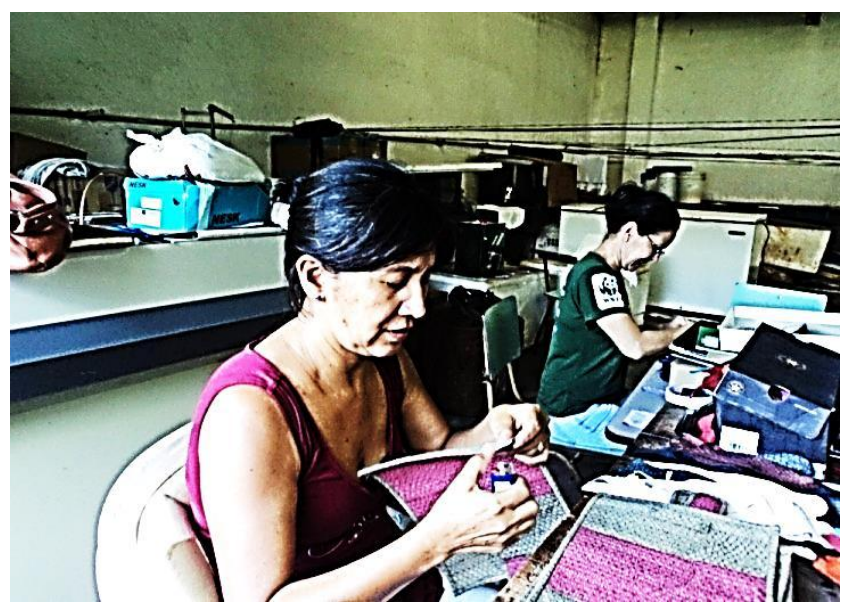

Fonte: <http:/ http:/www.wwf.org.br//>, acesso em 05 jan. 2014, às $21 \mathrm{~h} 45$.

Figura 66: Produtos acabados
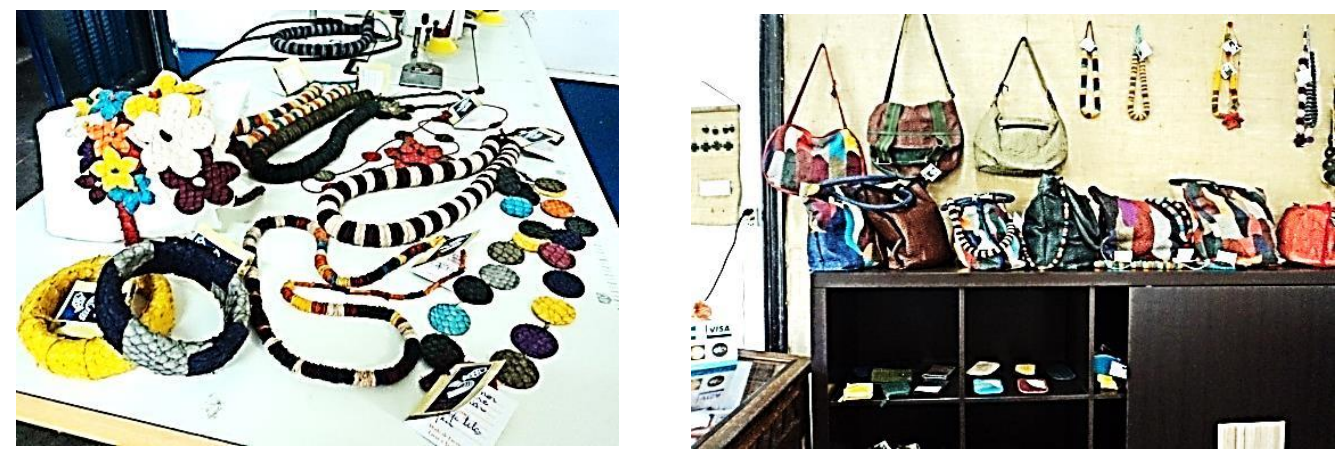

Fonte: <http:/ http:/www.wwf.org.br//>, acesso em 06 jan. 2014, às 21 h52.

Figura 67: Produtos acabados
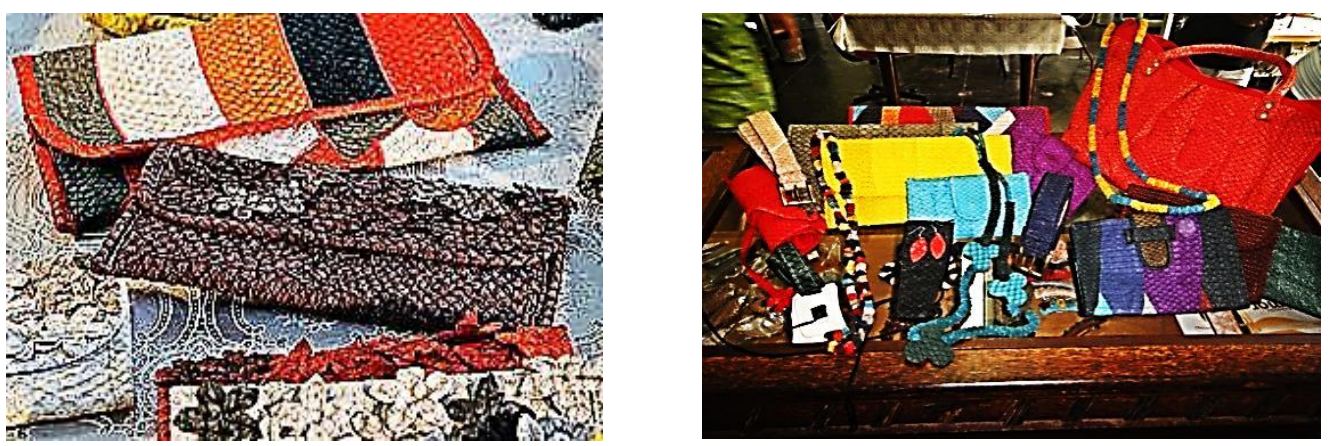

Fonte: <http:/ http:/www.wwf.org.br//>, acesso em 06 jan. 2014, às $21 \mathrm{~h} 59$.

\subsection{ARPEIXE}

O que para muitos é visto como descarte, para um grupo de mulheres é matéria-prima na confecção de acessórios de moda, além de renda para a família. A pele de peixes como tilápia, pacu, piauçu e piraputanga - tratada, curtida e tingida - é o material usado pelas mulheres da Associação Reciclando o Peixe (ARPEIXE), de Coxim, fundada em 2002 e filiada atualmente à Cooperativa dos Artesãos Mulher Peixe (COOPEARTEPEIXE), na confecção e comercialização de bolsas, pulseiras, cintos, carteiras e uma infinidade de outros 
artigos, que foram até expostos na Rio +20, Conferência das Nações Unidas sobre Desenvolvimento Sustentável, promovida no Rio de Janeiro.

Essa moda sustentável - de reconhecimento nacional - esteve na Rio $+20 \mathrm{com}$ apoio do programa Talentos do Brasil, do Ministério do Desenvolvimento Agrário (MDA), em parceria com o SEBRAE. Ao todo, 12 estados expuseram seus produtos (ARPEIXE, 2014).

A presidente da Cooperativa, Marlene Barbosa Mendonça, não havia sequer imaginado que um dia as bolsas, pulseiras e colares fabricados seriam expostos em um evento de repercussão mundial como esse. "A gente fica emocionada, nem imagina uma coisa tão extraordinária como essa", diz Marlene.

Com um ano e cinco meses de existência, a cooperativa surgiu dos trabalhos desenvolvidos na Associação Reciclando o Peixe (ARPEIXE), que continua em atividade e é mantida por parte dos integrantes da COOPEARTEPEIXE. A reclassificação do empreendimento ocorreu em decorrência do aumento das demandas recebidas e, consequentemente, da necessidade de vender os produtos para mais lojas e empresas. Com esse cenário, a expansão dos negócios encontraria alguns impedimentos jurídicos se os produtores permanecessem agrupados em uma associação.

A cooperativa é formada por 25 produtores familiares, dos quais 20 são mulheres. De acordo com a presidente da COOPEARTEPEIXE, os homens não trabalham diretamente com a produção. "Eles ficam na parte da gestão, da estruturação da cooperativa", diz Marlene.

Seguindo na direção norte do Estado de Mato Grosso do Sul, a 250 quilômetros da capital Campo Grande, chega-se a Coxim e Jauru, onde iniciou-se a pesca extrativista que deu origem à comunidade de pescadores da bacia do Rio Taquari. Em meados de 1970, com o crescimento da pesca amadora, os pescadores profissionais de Coxim e região se sentiram ameaçados. A maior retirada de peixes dos rios provocou uma diminuição do pescado e, como consequência, levou à migração das famílias ribeirinhas para a zona urbana.

Passaram-se os anos e a situação dos pescadores não mudou.

Foi então que, em 1998, um grupo de mulheres pescadoras, amigas desde a infância, resolveu aproveitar a pele de peixe para ganhar dinheiro. No início era apenas um grupo, o de artesãs, em uma comunidade de pescadores, lutando para conseguir uma forma de transformar os problemas a serem enfrentados. Trabalhar em grupo não era fácil. Aprender a aceitar novas ideias tornou-se uma necessidade para as mulheres ribeirinhas. Elas entenderam que seus produtos não valorizavam o material utilizado.

Em 2002, tendo à frente Marlene Barbosa Mendonça, as mulheres resolveram 
solidificar a união do grupo como forma de enfrentar o desafio de confeccionar produtos diferentes, que valorizassem a matéria-prima utilizada e atendessem a um público mais exigente.

"Quem come cabeça de pacu, sempre volta a Coxim". Esse era um ditado utilizado pelos moradores da cidade para atrair os visitantes e turistas, que apreciavam as deliciosas peixadas dos restaurantes localizados na beira do Rio Taquari (ARPEIXE, 2014. SITE: https://www.yumpu.com/pt/document/view/12960580/historias-de-sucesso-pantanal/5).

Marlene Barbosa Mendonça seguiu o ditado popular. Filha de pescadores pantaneiros, autêntica mulher ribeirinha, deixou Coxim ainda jovem para conseguir um trabalho melhor e poder ajudar a família. Ficou fora por oito anos. Em 1997, conheceu o trabalho em couro de peixe na Feira do Empreendedor, realizada pelo Serviço de Apoio às Micro e Pequenas Empresas do Mato Grosso (Sebrae/MT), em Cuiabá. Ficou impressionada com as formas de aproveitamento desse material, que normalmente era descartado pelos pescadores. Pensou que poderia aproveitar essa ideia de negócio em Coxim, pois seria uma alternativa de renda para as comunidades ribeirinhas.

Marlene retornou a Coxim em 1998 e procurou ajuda para pôr em prática a ideia que tinha em mente de aproveitar o couro do peixe, ou seja, a pele processada. Conversou sobre seus planos com Henrique Spengler e Francisco José De Paula, pessoas influentes na cidade, ligadas às questões da cultura, e também com pessoas que pudessem ajudá-la na busca de outros parceiros (ARPEIXE, 2014).

A ideia inicial se transformou em um projeto de desenvolvimento sustentável a partir do reaproveitamento dos subprodutos do peixe (pele, escamas e vértebras), envolvendo de início as mulheres dos pescadores não só na atividade produtiva, mas na preservação do meio ambiente e na manutenção da identidade cultural dos pescadores. Para Marlene, o importante era incentivar as mulheres a participarem do projeto, pois até então o trabalho delas era auxiliar o marido na pesca. Achou que poderia ajudá-las a ter um novo objetivo de vida.

Com a colaboração do Serviço de Aprendizagem Industrial de Mato Grosso do Sul (SENAI/MS) e da Prefeitura de Coxim, Marlene conseguiu fazer um estágio no Centro Tecnológico do Couro, no Rio Grande do Sul, onde aprendeu a trabalhar com couros exóticos. Com os ensinamentos que recebeu, conseguiu desenvolver a técnica necessária para beneficiar o couro de peixe da região do Pantanal. Aplicou também o conhecimento dos pantaneiros no curtimento do couro com extratos naturais. Passou a trabalhar de forma artesanal com taninos industrializados, produzindo um couro ecológico. 
O sonho de Marlene era montar um empreendimento coletivo, que envolvesse as famílias dos pescadores da Colônia de Pescadores Z-25, e organizar uma unidade de beneficiamento da carne do peixe e de curtimento e tingimento de peles. Em 1998, por meio do SENAI/MS, com recursos do Fundo de Amparo ao Trabalhador (FAT), foi ministrado em Coxim o curso de culinária Cozinha de Peixe, com a participação de 150 alunos dos municípios de Miranda, Corumbá e Coxim. Era o primeiro encontro e o passo inicial para reunir as mulheres e iniciar um trabalho com o pescado (ARPEIXE, 2014).

No segundo encontro, o grupo de mulheres de Coxim se interessou em iniciar o trabalho de aproveitamento total do peixe, proposto por Marlene. A Colônia de Pescadores disponibilizou suas dependências para as primeiras experiências. A Prefeitura de Coxim forneceu os peixes e emprestou os maquinários e instrumentos necessários (liquidificador, balança, moedor de carne, facas e bandejas). O grupo começou uma pequena produção. Já se podia ver nos olhos das mulheres a vontade de mudar a realidade em que viviam.

Com a organização, também vieram os problemas. As mulheres não conseguiam trabalhar em grupo. Apesar de viverem na mesma comunidade, perceberam que teriam de superar as divergências de opiniões e de valores individuais. Estavam habituadas a um trabalho de resultados imediatos, já que tudo que faziam, até aquele momento, era pescar e vender. Não sabiam como planejar e preparar adequadamente um produto para a venda.

Em função das divergências, da baixa oferta de peixe e da inexperiência, a produção era pequena e não atingia as expectativas do grupo quanto ao retorno financeiro. Nessa época as parcerias existiam, mas sem continuidade. Mesmo assim, aos poucos, o projeto foi tomando forma como fonte de renda alternativa e caminho para uma proposta de desenvolvimento sustentável.

Em 2000, o Consórcio Intermunicipal para o Desenvolvimento Sustentável da Bacia Hidrográfica do Rio Taquari (Cointa), a Colônia de Pescadores e o grupo de mulheres elaboraram um plano de negócios para a captação de recursos junto ao Ministério do Meio Ambiente (MMA). O plano foi construído de forma participativa e pretendia obter recursos para o fortalecimento e a reestruturação da colônia, atendendo às necessidades do grupo. As mulheres reunidas começavam a ter representatividade junto aos demais grupos da comunidade (ARPEIXE, 2014).

O plano norteou os encaminhamentos para a implantação e o desenvolvimento de empreendimentos coletivos, propostos desde o início pelas pescadoras. A partir daí, em 2002, a Secretaria de Promoção Social da Prefeitura de Coxim elaborou o Projeto Vale das Monções. O objetivo era a implantação de uma unidade de beneficiamento da carne e outra de 
curtimento da pele de peixe.

Enquanto esperava pela aprovação e liberação de recursos, Marlene não ficou parada. Em parceria com o produtor cultural Luis Carlos dos Santos, em 2002, elaborou o Projeto Reciclando Peixe para captação de recursos do Fundo de Investimento à Cultura do Mato Grosso do Sul (FIC/MS). A proposta era viabilizar a realização de oficinas de curtimento, tingimento e artesanato em pele de peixe, nos municípios de Coxim, Aquidauana, Miranda e Corumbá, todos na bacia pantaneira. Esses foram os primeiros passos para a implantação das associações de artesãs nos municípios de Coxim, Miranda e Corumbá. Para começar a oficina em Coxim, o grupo de mulheres fez parceria com a Associação das Costureiras de Coxim (Ascom), pois precisavam costurar algumas peças e as costureiras, organizadas e com local de trabalho próprio, ajudariam nessa tarefa. Na mesma época, o Cointa e o Sebrae/MS, em parceria com a Prefeitura de Coxim, promoveram a realização do curso de associativismo.

Com as aulas que estavam recebendo sobre o trabalho associativo, o grupo de mulheres começou a dar os primeiros passos para a criação da Associação de Artesanato de Peixe de Coxim (ARPEIXE). Nesse mesmo período, as pescadoras romperam com as costureiras. Houve um impasse entre os dois grupos. A Ascom já era uma associação organizada e as pescadoras, ainda, uma pedra a ser lapidada.

Com a separação, o grupo ficou sem lugar para trabalhar e dar andamento à ARPEIXE, pois ocupava o espaço cedido pelas costureiras. Na falta de um lugar melhor, as reuniões eram realizadas embaixo de uma árvore, em frente à colônia de pescadores. Foi então que Abenir Jesus de Brito, Margarida Camposano e Aparecida de Fátima Ribeiro Chaparro procuraram o presidente da colônia e lhe pediram que cedesse o espaço da Z-2 para que pudessem trabalhar. O presidente, Armindo Batista, sensibilizou-se com o problema que as mulheres enfrentavam e aceitou colaborar com o grupo. Faltava tudo, ninguém tinha dinheiro para começar. No entanto, elas tinham o lugar, a garra e o espírito de companheirismo para buscar uma solução. Começava, então, uma nova fase, na qual imperava a vontade de crescer, incrementar novos projetos e consolidar a ARPEIXE.

Ainda em 2002, Aparecida conseguiu o apoio da Empresa de Saneamento de Mato Grosso do Sul (Sanesul) para a montagem de um fulão. O Cointa disponibilizou o couro de peixe e os demais insumos e a Prefeitura de Coxim, as máquinas de costura. As amigas começaram a produzir, apesar das dificuldades que enfrentavam. Naquela época, elas haviam concluído o curso de associativismo e estavam dispostas a organizar a associação de mulheres de Coxim. Os resultados financeiros ainda não correspondiam às expectativas. As mulheres vendiam em média 20 peças por mês, o que representava aproximadamente $40 \%$ da produção. 
Em 2003, com o apoio do Sebrae/MS, juntaram-se ao grupo cinco mulheres: Lúcia Canutti, Antonia Maria da Costa, Sueli Rocha Wisenfad, Aparecida Clepaldi Morais e Maria Naban. Juntas foram até Dourados (MS) para uma visita técnica e para estabelecer parcerias de fornecimento de couro de peixe. A região de Dourados era um polo de piscicultura do Estado e, por essa razão, a oferta de pele de peixe era grande.

A organização e união do grupo resultaram em um avanço em relação à responsabilidade social e ao desenvolvimento sustentável. A decisão de não utilizar o cromo, produto químico que contamina o solo e a água, foi unânime. Passaram a utilizar o tanino e extratos vegetais. Esse respeito pelo meio ambiente resultou no desenvolvimento de técnicas de produção limpa, reduzindo-se a emissão de resíduos tóxicos e, como consequência, criando-se um diferencial positivo no mercado. "Queremos produzir um couro ecológico, macio, resistente e fácil de costurar", comentou a associada Lucia Canutti.

Em junho de 2003, foi feita a divulgação do projeto da ARPEIXE na revista Pequenas Empresas \& Grandes Negócios, e logo após, na revista Globo Rural. A partir daí, o grupo começou a ter visibilidade nacional e outros estados vieram ao Mato Grosso do Sul para aprender com as experiências da associação, principalmente, a tecnologia desenvolvida no curtimento da pele de peixe.

Em setembro de 2003, a ARPEIXE foi legalmente constituída. Naquele mesmo ano ficou pronta a microunidade de beneficiamento da carne, curtimento do couro e artesanato do couro de peixe. Em maio de 2006, com o apoio de Patrícia Mendes, a ARPEIXE participou da Oficina de Design, que fazia parte do Projeto Talentos do Brasil, desenvolvido pelo MDA Ministério do Desenvolvimento Agrário -, com apoio do Sebrae/MS, Petrobras, Prefeitura de Coxim, Cointa, SENAI, Instituto Brasileiro de Meio Ambiente e dos Recursos Naturais Renováveis (IBAMA) e WWF-Brasil. Antes do início da oficina, o Sebrae/MS realizou um diagnóstico do grupo com o objetivo de fornecer subsídios à equipe de design, em relação à comunidade local, capacidade de produção, infraestrutura, técnicas e matérias-primas utilizadas.

Entre as diversas ações, a oficina tinha como metas agregar valor ao artesanato, desenvolver novas linhas de produtos, utilizar novas tecnologias e buscar novos mercados. A melhoria e o aperfeiçoamento dos processos de gestão, produção e mercado eram base de sustentação do projeto. Era tudo que a ARPEIXE precisava para incrementar sua produção.

A Oficina de Design contou com uma equipe formada pelo coordenador geral e designer Renato Imbroisi, a estilista de moda Liana Bloisi, a arquiteta Maria Cristina Cuervo Moura, a designer gráfica Claudia Portela, a fotógrafa Lena Trindade e a consultora Ângela 
Klein. Foram oito dias de intensa criação e elaboração de novas ideias para a produção da ARPEIXE. A oficina proporcionou um mapeamento das técnicas e métodos utilizados na confecção de produtos e visualizou as diversas possibilidades de utilização do couro de peixe, juntamente com outras matérias-primas naturais.

No decorrer da oficina foram detectados pontos até então não trabalhados pela ARPEIXE, como linha de produtos sem foco de mercado, o desperdício de materiais e a ausência de planejamento. A equipe de designers constatou a possibilidade de inovar na produção, respeitando as singularidades do grupo, assim como a sua capacidade de produção. O direcionamento foi para um mercado que estava em franca expansão e buscava produtos artesanais diferenciados com algum valor agregado, isto é, a personalização das peças com características da identidade local e da cultura regional. Haveria confecção de produtos com identidade própria, diferente dos produzidos até então.

Os grupos foram divididos de acordo com as suas habilidades e definiu-se uma possível linha de produção. Estabeleceu-se um plano de ação, tendo como referência o potencial técnico e produtivo. O método de trabalho fez com que as falhas anteriores, como o não aproveitamento de sobras de peles, virassem inspiração para novos produtos. Os possíveis defeitos deram lugar à capacidade criativa. O que anteriormente era tido como baixa qualificação da mão de obra se transformou em técnicas utilizadas para o acabamento dos produtos.

Foi necessário que o grupo fizesse uma capacitação em meio à Oficina de Design. A necessidade de aperfeiçoamento técnico para melhoria de acabamento foi uma das exigências para a confecção de um produto de qualidade.

Ao término da oficina, as participantes estavam eufóricas com os resultados obtidos. As técnicas que possuíam, acrescidas do aprendizado recebido e a disponibilidade de matériaprima, proporcionaram a confecção de uma coleção que foi denominada Mulher Peixe.

As peças da coleção foram conceituadas a partir da identidade local, e tirou-se proveito dos nomes de espécies de animais, de flores, de peixes, de tribos indígenas, ou seja, dos ícones locais. Foram criadas em torno de 120 peças, entre bolsas, carteiras, cintos, colares, brincos, porta-níqueis, porta-óculos, broches e presilhas. As vértebras e as escamas de peixe foram transformadas em colares, brincos e acabamentos de bolsas, agregando maior valor aos produtos e aproveitando o que antes era pouco explorado. $\mathrm{O}$ couro bovino e a argila também foram utilizados como matéria-prima.

Para a divulgação do trabalho da associação foram produzidos catálogos, cartões de 
visita, etiquetas para mercadorias e banners, juntamente com o lançamento da coleção no Rio Fashion Business, em junho de 2006, como parte do Projeto Talentos do Brasil. As peças publicitárias tiveram como modelos as próprias artesãs. Elas foram fotografadas nas margens do rio e na água como mulheres peixe, o título da coleção (ARPEIXE, 2014).

Houve uma preparação para a participação da ARPEIXE em feiras e eventos. Foram feitos estudos para análise de custos e determinação do preço de venda. A elaboração de fichas técnicas permitiu a reprodução fiel dos itens do produto, atendendo-se assim à necessidade dos lojistas quanto à padronização.

Ainda em 2006, a ARPEIXE foi convidada a participar de outros eventos, como Paralela Gift, em São Paulo (SP); Festival de Inverno de Bonito, em Bonito (MS); $3^{\text {a }}$ Feira de Mulheres em Movimento, em Campo Grande (MS); Feira Industrial do Pantanal, em Campo Grande (MS); Rodada de Negócio Top 100 Artesanato, em São Paulo (SP); e Feira Nacional da Agricultura Familiar e Reforma Agrária, em Brasília (DF).

A produção foi direcionada a um público diferenciado e mostrou o caminho que deveria ser seguido. O planejamento colocado em prática e os resultados obtidos nos eventos superaram as expectativas da equipe de designers e das artesãs da ARPEIXE. Diversos contatos foram feitos e a comercialização foi imediata, iniciando-se a primeira produção em grande escala. Tanta dedicação e comprometimento resultaram no sucesso da coleção e no reconhecimento obtido por meio do Prêmio SEBRAE Top 100 de Artesanato de 2006. Além disso, possibilitaram a indicação, também em 2006, ao Prêmio Mercado Design Top XXI14, na categoria Design Sustentável, sendo vencedora a coleção Mulher Peixe (ARPEIXE, 2014).

Os prêmios conquistados pela ARPEIXE colocaram-na definitivamente no mercado como uma empresa de artesanato amadurecida e disposta a enfrentar novos desafios.

Agregar valor social, cultural e ambiental ao artesanato acabou se transformando em um conceito de trabalho organizado. As mulheres entenderam que, em cada peça que elas produziam, havia um pouco de sua história de vida, do lugar onde moravam.

“Em 2006, foi desenvolvida a coleção que nos projetou para um mundo jamais sonhado e vivido. No Rio Fashion, realizado no Rio de Janeiro, desfilamos nosso artesanato com elegância", comentou Marlene.

Em 2007, a ARPEIXE passou por uma revitalização interna com o objetivo de atender à proposta de aumentar a comercialização fora do estado. O grupo mostrou que tinha absorvido o conceito de cooperação, deixando de lado o isolamento e o individualismo. A associação vivia seus melhores momentos e a expansão era uma necessidade. 
Buscar a autonomia financeira passou a ser a meta da ARPEIXE. Até então, as mulheres do grupo estavam se capacitando como empresárias de forma a atender o mercado. A percepção era de que os riscos passavam a ser menores, os produtos eram aceitos de forma positiva e, consequentemente, havia aumento nas vendas.

A proposta futura era completar a cadeia produtiva, desenvolvendo a produção dos peixes, passando pelo beneficiamento da carne e da pele, além da confecção de peças artesanais com o couro do peixe. A ideia decorreu da oscilação no preço e na oferta de peles comercializadas pelos frigoríficos e psicultores, o que trazia insegurança quanto à aquisição da matéria-prima.

Um projeto como esse necessitava de um envolvimento maior dos parceiros e de toda a comunidade, pois se tratava de uma ideia ambiciosa. $\mathrm{O}$ artesanato continuaria sendo a proposta principal, pois a pele representava o subproduto com maior valor agregado e com possibilidade de rentabilidade maior.

As peças comercializadas pelas artesãs são produzidas a partir do couro do peixe in natura, adquirido na região. Todo o tratamento da matéria-prima é feito sem química, com extrato vegetal retirado da flor da acácia, comprado na região Sul do País. "A pele chega com gordura, escamas e até pedaços da carne do peixe. Primeiro, nós a limpamos utilizando uma colher; depois, vai para uma máquina, que finaliza o processo de limpeza total. Assim, fica pronta para o curtimento. Apenas as tintas para tingimento não são naturais”, explica Lúcia Aparecida Canuti, presidente da ARPEIXE há 4 anos e que já exerceu a profissão de pescadora.

Segundo ela, o processo para que o couro do peixe fique pronto para ser transformado dura 24 horas. "Entre limpeza, tingimento e secagem, um dia. Então, as melhores peles transformam-se em bolsas, carteiras e outros acessórios. Até os retalhos nós aproveitamos", explica Lúcia, lembrando que grifes como as do estilista Ronaldo Fraga e Le Lis Blanc já colocaram seus nomes em produtos que elas criam. "Nós trabalhamos por encomenda. Pode ser para feiras ou para uma coleção, mas tudo é feito por meio da cooperativa e do projeto Talentos do Brasil" (ARPEIXE, 2014).

Quando se lembra da maneira como a cooperativa foi concebida, Marlene se emociona. "Com a escassez dos pescados, comecei a ver o pessoal ribeirinho indo para a zona urbana. Mas nas cidades, geralmente, eles não estavam preparados para os postos de trabalho e aí vinha o choque social. Pensei nesse tanto de couro de peixe e de mulher desempregada, precisando de um emprego", conta. 
Passado algum tempo, a cooperativa já colhe bons frutos. Produz, em média, 1,5 mil peças mensais em um núcleo próprio para a produção. Atualmente, trabalha para atender à demanda de uma empresa brasileira que fornecerá os produtos da COOPEARTEPEIXE para a cidade de Dallas, nos Estados Unidos.

Também já exportaram para a França e a Alemanha. As vendas foram viabilizadas pelo programa Talentos do Brasil, uma iniciativa do Ministério do Desenvolvimento Agrário.

Figura 68: Confecção dos produtos.
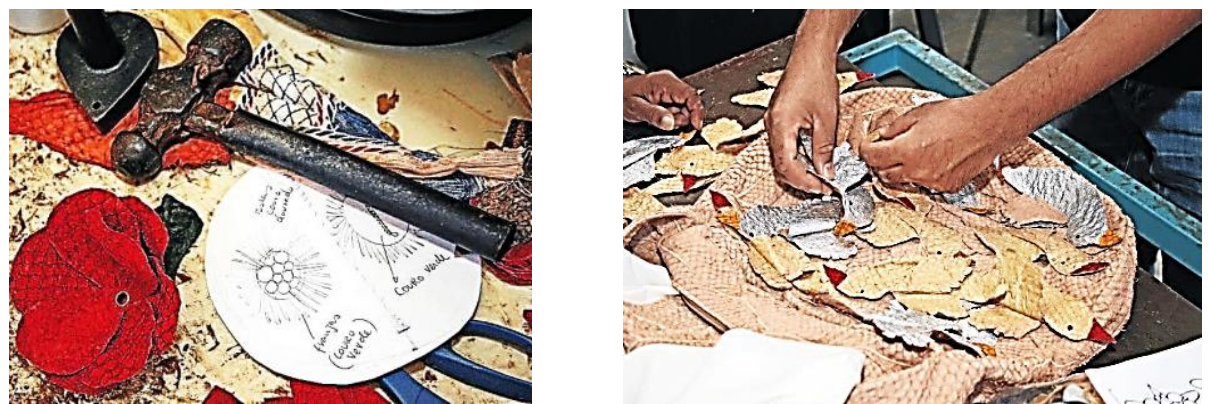

Fonte: <http://mulherpeixe.wordpress.com/2009/07/21/foto-da-arpeixe/>, acesso em 07 jan. 2014, às 06h43.

Figura 69: Produtos acabados
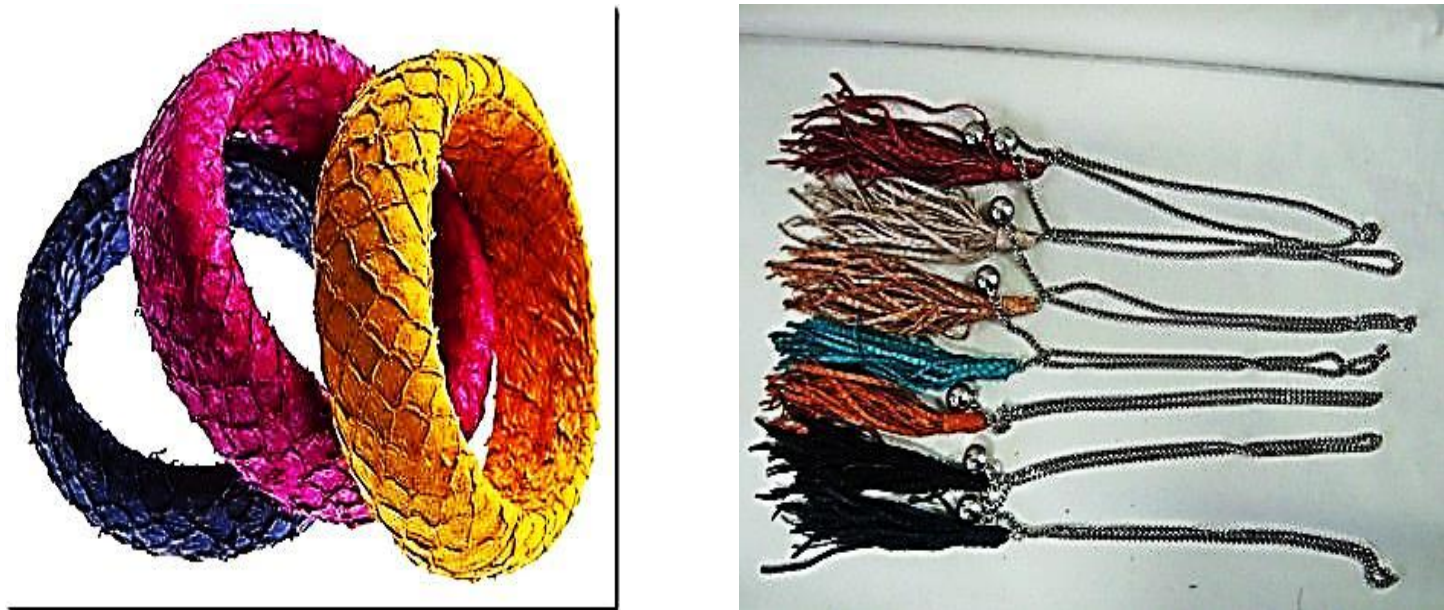

Fonte: <http://mulherpeixe.wordpress.com/2009/07/21/foto-da-arpeixe/>, acesso em 07 jan. 2014, às 07h01.

\subsection{COPESCARTE}

As colaboradoras da cooperativa estavam preocupadas com a questão da gestão dos resíduos sólidos, líquidos e orgânicos oriundos da ação pesqueira, a falta de oportunidade na geração de trabalho e renda, aliadas à baixa escolaridade e à baixa qualificação profisssional, decidiram formar a COPESCARTE. Inicialmente, foi formado um grupo de 20 mulheres marisqueiras e pescadoras dos bairros Portinho, Graciosa de Cima e Graciosa de Baixo, que informalmente vinham desempenhando atividades de qualificação profissional junto às cooperadas. Mesmo sem recursos financeiros as cooperativadas conseguiram fundar e 
registrar a COOPESCARTE junto à Junta Comercial do Paraná e na Secretaria da Receita Federal - Cadastro Nacional de Pessoa Jurídica 09.124.184/0001-76 e Inscrição no CAD/ICMS 90.419.369-05 e o título de Utilidade Pública Lei nº45/09 (COOPESCARTE, 2014).

A Cooperativa das Trabalhadoras Autônomas da Pesca e Acessórios Artesanais COPESCARTE foi constituída em 19 de julho de 2006 e formalizada em 14 de outubro de 2006. Trabalha com resíduos do pescado (pele de peixe), beneficiando-os e transformando-os em couro de peixe para confecção de artesanatos. Tem por objetivo provocar impactos positivos nos indicadores sociais e ambientais, com foco nas famílias da comunidade da pesca, fomentando o associativismo e o cooperativismo, além de oferecer oportunidade de trabalho e geração de renda como estratégia emancipatória para o desenvolvimento autossustentável e solidário. $75 \%$ das mulheres que participam da cooperativa não tiveram ou não têm essas oportunidades de trabalho e renda. Hoje, com qualificação profissional, elas participam das atividades da COPESCARTE e, assim, adquirem maior valorização pessoal e uma visão melhor para o futuro.

O projeto inclui efetivamente as cooperadas socialmente, possibilitando renda e capacitação profissional. Além disso, gera dignidade e respeito para que possam participar das decisões da sociedade e da comunidade (COPESCARTE, 2014).

Em 2010 a COPESCARTE conseguiu apoio financeiro da Fundação Interamericana dos Estados Unidos, que vem ajudando a Cooperativa na compra de alguns equipamentos e manutenção dos custos fixos. Em 2011 teve o seu Projeto Renda Mulher aprovado pela Eletrosul para compra de móveis. Vem trabalhando na orientação sobre a violência contra as mulheres, tráfego de mulheres e meninas e saúde das mulheres; orientando e buscando parcerias para desenvolver esse tipo de trabalho.

Dentro da cooperativa já houve registro de resgate social, que serviu como motivo de publicação em um livro escrito por Ricardo Bueno, intitulado Mãos, meninas, mulheres: a cultura como ferramenta de inclusão social (COPESCARTE, 2014).

A presidente da cooperativa, Sra. Leocília Oliveira da Silva, foi reconhecida com o Prêmio Ruby pela ONG Soroptimista Internacional Curitiba Glória, que homenageia mulheres que, por meio de seus esforços pessoais e profissionais, fazem diferença na vida de outras mulheres e meninas.

A COPESCARTE participou do Prêmio Valores do Brasil pelo DRS Desenvolvimento Regional Sustentável do Banco do Brasil. 
A COPESCARTE é pioneira na arte do beneficiamento das peles de peixes marinhos e está satisfeita em colaborar com o desenvolvimento econômico e sustentável da região.

Figura 70: Confecção de produtos.
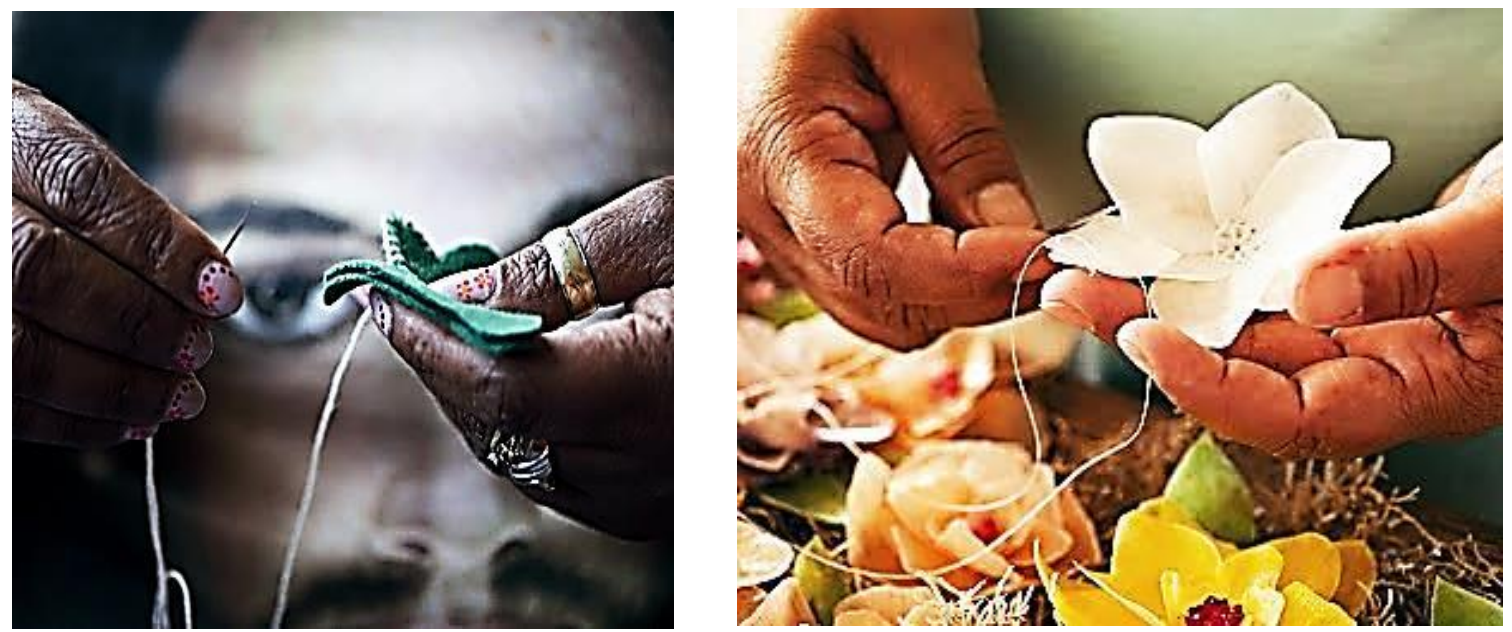

Fonte: <http://www.fiepr.org.br/nospodemosparana/uploadAddress/Reciclando_o_Pescado[39805].pdf>, acesso em 07 jan. 2014, às 09h14.

\subsection{Pérolas do Guarujá}

A Cooperativa Pérolas do Guarujá - COOPEG foi criada em maio de 2011, seguindo a tendência da produção sustentável, visando gerar renda para as mulheres da comunidade pesqueira do município de Guarujá, mediante o beneficiamento da pele de peixe proveniente da pesca artesanal, a qual era descartada no meio ambiente. Essa união permitiu a produção de artesanato com couro de peixe, atuando em um mercado em plena ascensão - o dos ecoprodutos.

O conceito de produção ecológica é evidenciado pelo uso de um processo inovador para curtir a pele, o qual foi patenteado e é realizado com produtos atóxicos e sem água. Com isso, não há despejo de efluentes líquidos para o meio ambiente.

O apoio da Prefeitura do Guarujá, disponibilizando espaço físico, foi fundamental para sua estruturação. A prefeitura garantiu também o suporte técnico, por meio de parceria com o ICA (Instituto de Cooperativismo e Associativismo), já que a COOPEG não apresentava capital financeiro.

Desde sua constituição, a cooperativa vem desenvolvendo sua função social, promovendo a inserção cultural e o aumento da renda na região.

A COOPEG foi fundamentada em princípios socioambientais, capacitando as pessoas e comercializando produtos artesanais, os quais são elaborados com matéria-prima que seria 
descartada no meio ambiente. Os produtos são confeccionados com o subproduto da pesca artesanal - pele de peixe e escama - e da indústria têxtil, a partir de retalhos de tecido.

Diogo Borges Rodrigues de Sá, 29 anos, biólogo, afirma que o resultado obtido no couro de peixe fabricado pela cooperativa é o de um material bem firme e mais fácil de manufaturar. Assegura que o material possui as mesmas vantagens encontradas no couro bovino, com a diferença de ser mais bonito e resistente.

Autor do método natural de transformar a fina camada de pele em um couro exótico, ele também é a voz de liderança da COOPEG, que desde a sua fundação é a esperança de uma melhor qualidade de vida para quase 20 famílias.

Com sobras da indústria têxtil e resíduos da atividade pesqueira, o grupo integra uma rede de geração solidária de renda, a partir de uma produção sustentável de bolsas, carteiras, chaveiros, abajures e até assentos de cadeiras.

Entretanto, apesar do bom intuito, a organização ainda engatinha por falta de estrutura e de visibilidade. Máquinas de costura profissionais chegaram há pouco tempo. Foram todas doadas. Antes, todos os arremates eram feitos lentamente, com linhas, agulhas e a força das mãos.

Nas estruturas cedidas pela prefeitura, faltam, por exemplo, espaços mais amplos para expandir a produção. "Tínhamos condições difíceis de trabalho. Agora, acredito que começaremos a colher melhores frutos", avalia o coordenador da cooperativa (COOPEG, 2014).

\subsubsection{Técnica de produção}

O desenvolvimento da técnica é resultado da determinação. Assim que se formou biólogo, Diogo deixou o emprego em uma piscicultura para se dedicar a desenvolver uma técnica orgânica que resultasse em couro de peixe. Atualmente, as formas possíveis de transformação do resíduo em couro consomem quantidade excessiva de água e até 24 produtos químicos - que podem contaminar lençóis freáticos.

"Minha maior preocupação era o descarte das peles, que sempre foi um problema sem solução. As técnicas industriais (de curtição da pele de peixe) são nocivas à natureza e provocam perda da qualidade natural das escamas", afirma ele.

As primeiras experiências começaram há quase oito anos, no quarto de sua casa, em uma cidade do interior do Estado de São Paulo. A cada nova etapa, menos material químico era utilizado no procedimento. Hoje, todo o processo é feito com pequena quantidade de uma 
mistura de sais minerais e uma estufa.

“Queria uma proposta sustentável. Nosso processo é mais rápido e mantém a característica natural dos peixes”, explica Diogo (COOPEG, 2014).

\subsubsection{Pescadores}

O município do Guarujá concentra uma das maiores comunidades pesqueiras do litoral paulista. Ainda assim, o biólogo diz enfrentar dificuldades para obter a pele.

“Muitos preferem jogar fora a doar". Já o material que resulta da manufatura geralmente, resto de carne de peixe raspado da pele - vai para uma composteira para ser transformado em adubo natural.

Em comparação à técnica empregada pela indústria, o know-how desenvolvido pelo biólogo possibilita aceleração do processo, que se torna sete vezes mais rápido. "Dependendo do tamanho da pele, todo o processo é feito em um dia, e dependendo da peça a ser fabricada, em algumas horas. Já com o outro modelo, leva-se até uma semana para se obter o produto final", diz.

Mesmo mais bonito, o artesanal tem o mesmo preço do produto industrializado. Em comparação ao couro convencional, o custo de revenda é cerca de $150 \%$ maior.

\subsubsection{Dedicação ao projeto}

Finalizadas todas as experiências, o passo seguinte foi o de registrar a patente da técnica. Em busca de matéria-prima abundante, Diogo Rodrigues de Sá desembarcou no Guarujá, onde conseguiu aprovação da Incubadora Pública de Empreendimentos Solidários (IPES) para levar o projeto adiante.

"Fiz cursos de corte e costura, design de sapatos, bolsa... Tive que aprender a lidar com o material", explica.

Versátil, o couro artesanal não tem limites para ser aplicado. Bolsas, carteiras, brincos, chaveiros, sapatos, entre outros, enfim, o que a criatividade permitir. "Apliquei em um painel de carro e em cadeira de escritório. Pode-se usar esse tipo de matéria-prima em tudo, não tem limite, porque o tecido é bem fácil de manusear".

Diogo acredita no crescimento do mercado de peles exóticas no Brasil, uma realidade ainda distante. Hoje, a maior parte da produção é vendida em feiras de artesanato ou em eventos turísticos. "É sucesso garantido", diz o biólogo. As peças mantêm os detalhes naturais 
da escama. "Nenhum peixe é igual ao outro, por isso, cada objeto se torna único".

\subsubsection{Vitrina}

As peças produzidas pelas mulheres das comunidades pesqueiras atreladas à Cooperativa Pérolas do Guarujá são vendidas em feiras de artesanato e eventos turísticos. São bolsas, carteiras, porta-moedas, pulseiras, brincos e até sapatos. As peças já foram exportadas para alguns países da Europa, como, por exemplo, Espanha, Itália e Portugal.

\subsubsection{Processo de produção}

Aproveitando a visita feita ao espaço onde fica localizada a cooperativa, foi possível o acompanhamento direto do processo ecológico de produção das peles.

Figura 71: Guia explicativo do modo de produção.

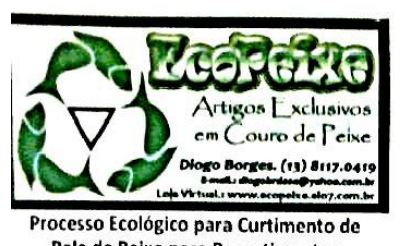

Processo Ecológico para Curtimento de Pele de Peixe para Revestimentos

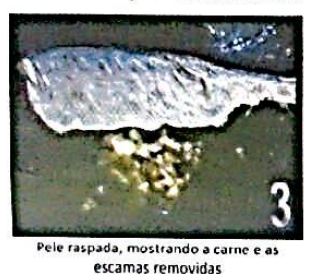

escamas removidas

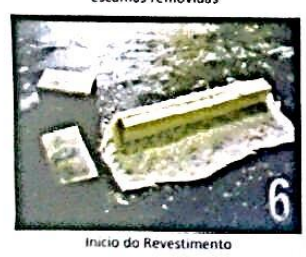

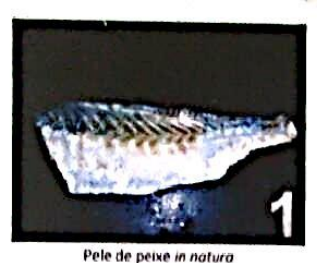

Pele de peixe in noturo

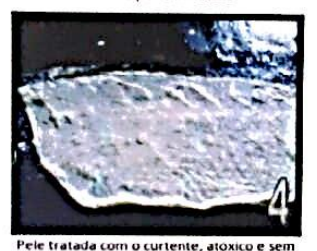

agua, desenvolvido

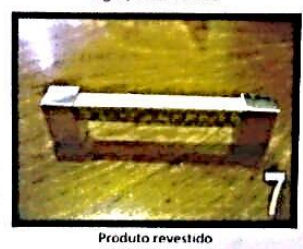

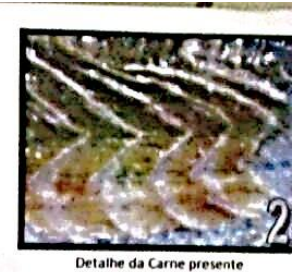

Detalhe da Carne presente
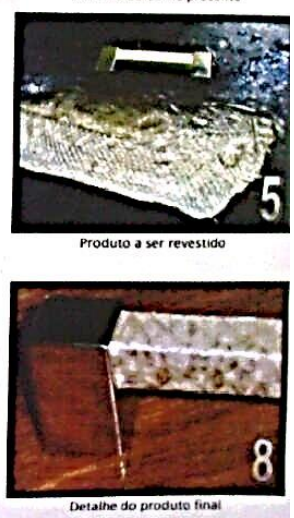

Fonte: <http://www.perolasdoguaruja.com.br/>, acesso em 08 jan. 2014, às 07h01.

É possível encontrar abaixo a explicação ilustrada de cada uma das etapas.

Figura 72: Peles limpas. 


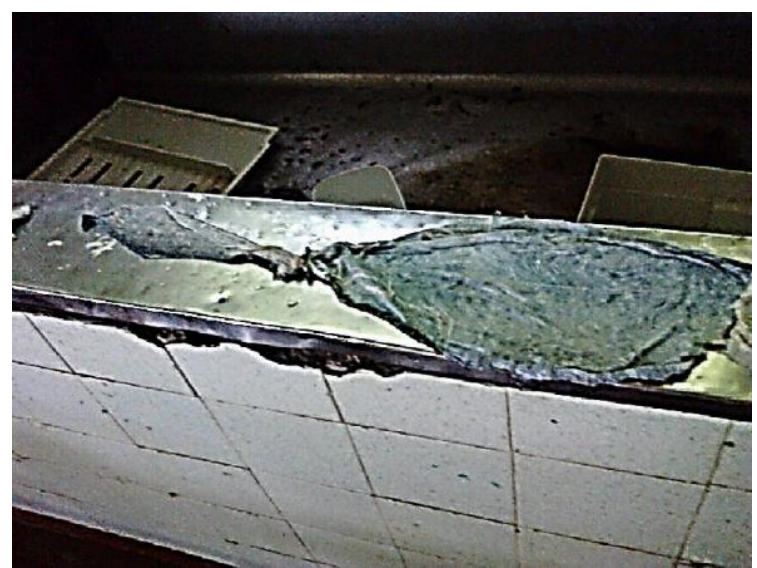

Fonte: Arquivo pessoal.

As peles visualizadas na foto acima estão completamente limpas, puras e prontas para o processo. Após a obtenção das peles, é comum que contenham resquícios de carne. Para que o processo possa ser feito com segurança no resultado positivo, é necessário que todas as peles sejam bem limpas e "raspadas" com objetos pontiagudos, como facas. Somente assim é possível comprovar que a pele está totalmente livre de carne e o processo será realizado com sucesso.

Figura 73: Pele de linguado.

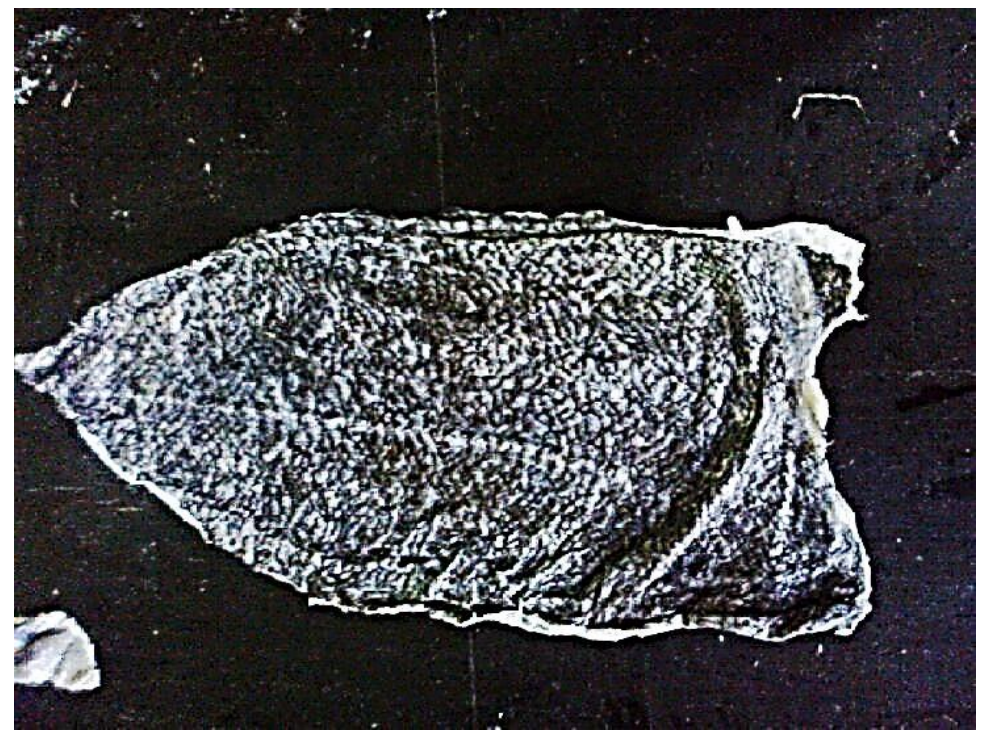

Fonte: Arquivo pessoal.

A espécie de peixe escolhida para a realização do processo foi o linguado. O linguado é um peixe que possui somente uma cor, um cinza escurecido, conforme pode-se observar na imagem ilustrada acima. 
Por mais que certas espécies de peixe não apresentem variações de cor, na maioria dos espécimes foram encontradas diferenças de coloração na região da barriga do animal. Ao procurarem comida em seu habitat natural, rios e mares, muitas das espécies costumam rastejar e encostar a barriga no fundo daquele ambiente. Agindo desta maneira, a pele que fica localizada na parte inferior do animal geralmente apresenta coloração bem mais clara, como se pode observar na imagem ilustrada abaixo:

Figura 74: Linguado. Peça de cor escura (dorso do animal) e peça de cor clara (barriga do animal).

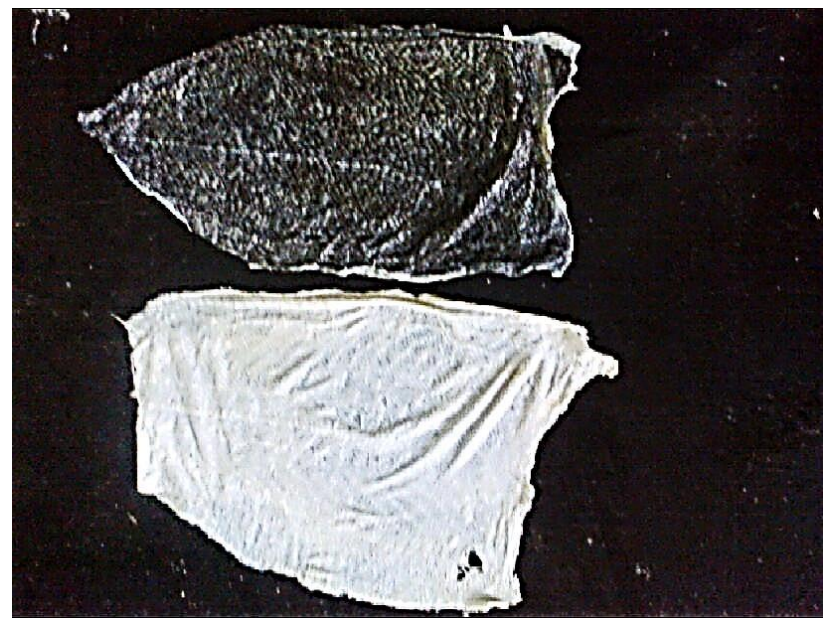

Fonte: Arquivo pessoal.

No caso específico do linguado, não é possível afirmar que o animal nade com a barriga rastejando no solo dos rios. Pois, segundo o biólogo, o linguado é um peixe que nada “de lado" e não "em pé”, como a maioria das outras espécies. Portanto, as laterais do corpo do animal apresentam coloração diversificada, em função deste fato.

Figura 75: Utilização da cola.

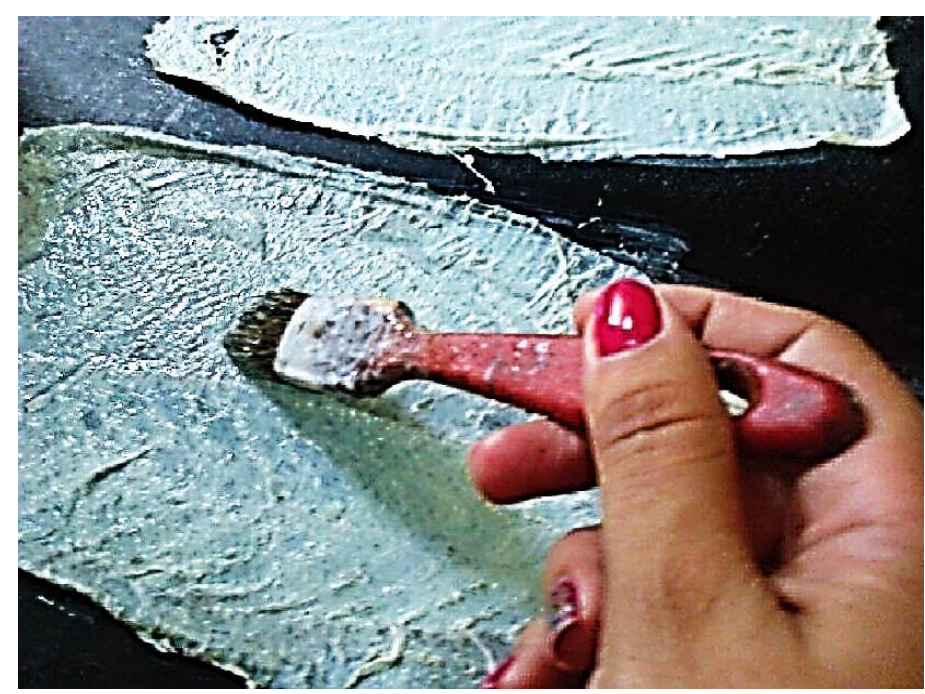

Fonte: Arquivo pessoal. 
Após o processo de limpeza das peles, elas são colocadas esticadas, do lado oposto, onde localizava-se a carne do animal. Pincela-se cola branca por toda a superfície dessa região. O biólogo afirma adicionar mistura aromatizante à cola, para aliviar o odor característico do peixe.

Figura 76: Pulverização da mistura de sais minerais.

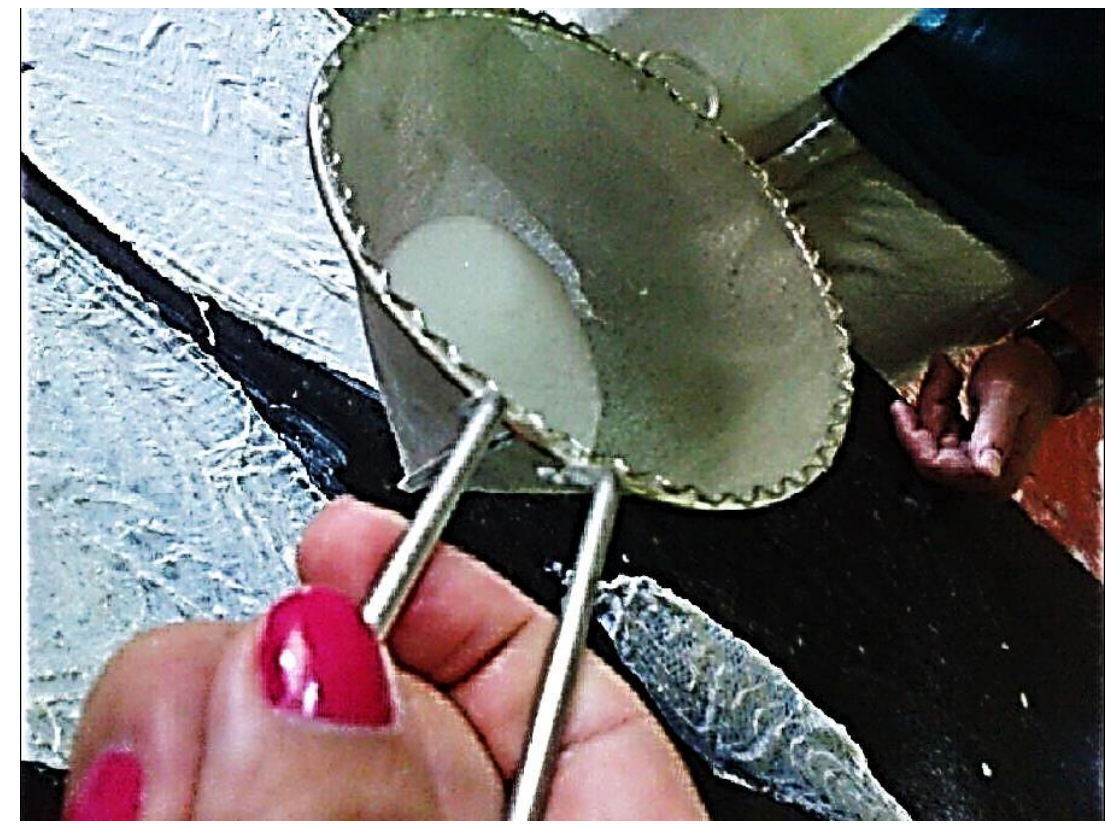

Fonte: Arquivo pessoal.

Depois de a cola ser pincelada na pele, é hora de polvilhar a mistura de sais, com a ajuda de uma peneira. A composição da mistura é um segredo, que o biólogo não revela em hipótese alguma.

Figura 77: Material revestido com a pele curtida.

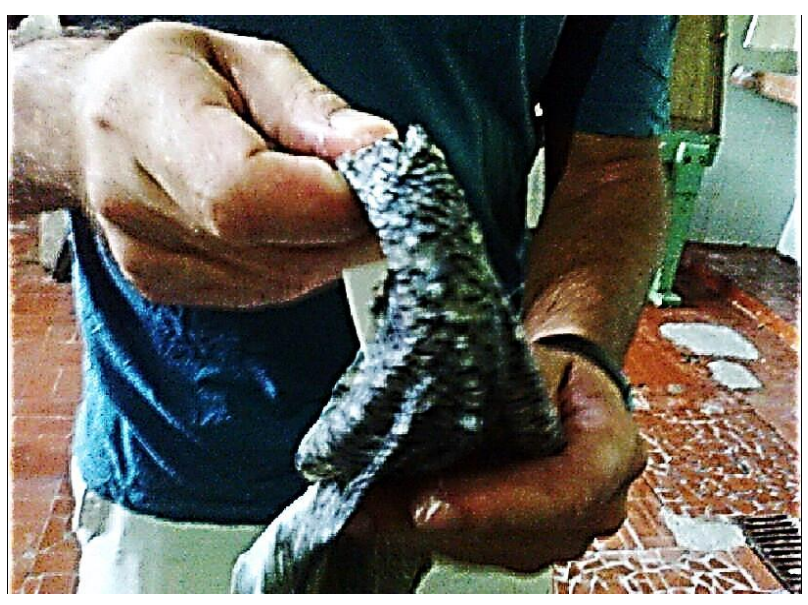

Fonte: Arquivo pessoal. 
Após essas duas etapas o couro já passou pelo processo de curtimento. Antes de ser levado à estufa, deverá revestir a peça escolhida.

Nesse caso, como pode-se comprovar na imagem acima, a peça escolhida foi um bracelete.

A pele foi envolvida na peça, tendo suas sobras aparadas, e foi, com a ajuda da cola branca, fixada mais facilmente.

É levada a uma estufa de uso comum, à temperatura de $50^{\circ} \mathrm{C}$. Após um tempo variável entre 20 e 30 minutos, já está seca e pronta para uso.

Em alguns casos, se o material a ser trabalhado for uma manta de tecido, produzido com o couro de peixe, esse material, após sair da estufa, encontrar-se-á muito rígido e ressecado.

É necessário, portanto, amaciar a peça. O amaciamento, segundo Diogo, é feito de duas maneiras diferentes:

- Amaciamento manual e hidratação

Com auxílio das mãos, e em movimentos de lavagem (como se estivesse lavando manualmente uma peça de roupa), é possível amaciar a pele, sendo de muita ajuda o uso de um hidratante corporal.

\section{- Cerveja}

A cerveja, quando entra em contato com a pele finalizada (após passar pelo processo citado anteriormente), causa amaciamento imediato do couro.

Infelizmente, não é possível o uso do amaciamento com cerveja em peças do vestuário ou acessórios de uso pessoal. Pois, após o amaciamento, se o couro for lavado com produtos de limpeza tradicionais, como detergentes, sabões em pó ou em barra, o couro volta a ficar ressecado, como antes do processo de amaciamento.

No caso de objetos que são utilizados como peças artesanais, objetos de decoração ou mesmo objetos que não apresentem necessidade de lavagem, o uso do amaciamento com cerveja é mais prático e rápido. 


\subsubsection{Tingimento das peças}

O tingimento das peças é feito com corantes utilizados na indústria cosmética ou corantes naturais, como, por exemplo, café, beterraba, hortaliças e outros alimentos corantes.

Figura 78: Corante utilizado na indústria cosmética, de aspecto pastoso, que quando utilizado como tingimento apresenta coloração azul-cintilante (à esq.); corante utilizado na indústria cosmética, encontrado na forma de pó, e que apresenta a coloração amarela (centro); corante utilizado na indústria cosmética, em formato de calda, que quando utilizado apresenta coloração de aspecto "caramelo" (à dir.).

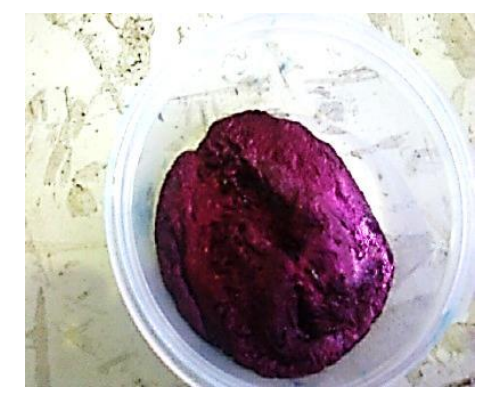

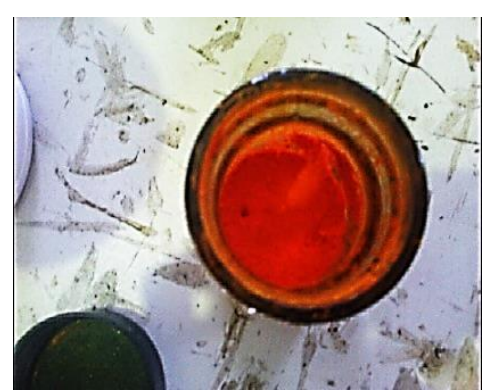

Fonte: Arquivo pessoal.

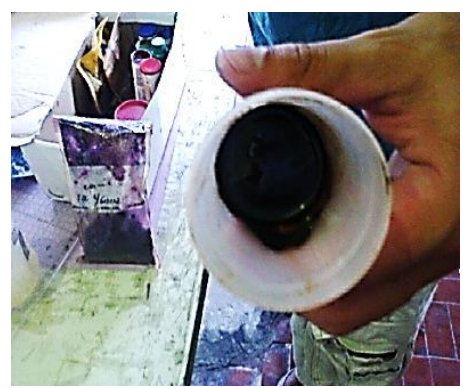

Figura 79: Beterraba, legume que apresenta forte coloração e que, quando cozido, libera corante natural. Sua cor apresenta aspecto marcante e é de fácil fixação (à esq.); café: após moído e fervido em água quente, sua borra é capaz de tingir (centro); couve verde, cujas folhas, quando cozidas, liberam coloração esverdeada que pode ser utilizada como tingimento (à dir.).

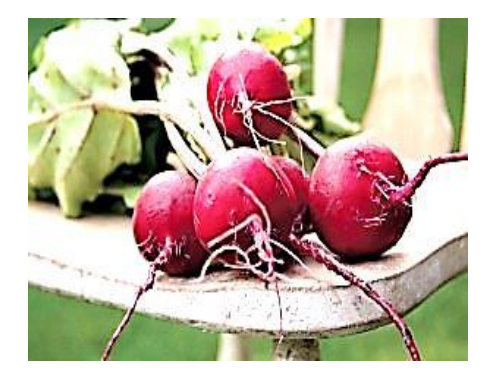

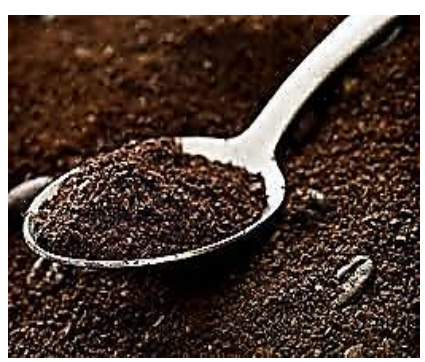

Fonte: Arquivo pessoal.

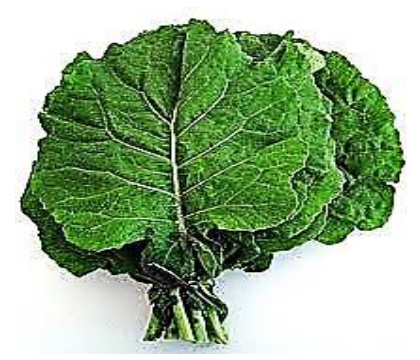




\section{CONSIDERAÇÕES FINAIS}

A importância da descoberta de um novo substrato têxtil é grandiosa. O avanço da tecnologia e a aparição de novos materiais contribuem significativamente para a evolução da humanidade e o beneficiamento da população.

A moda baseia-se na criação de novas propostas, ideias e inspirações. O surgimento de novos produtos gerados pela tecnologia têxtil e oferecidos ao mercado têxtil e de confecção é de grande valia e só traz benefícios a toda "cadeia têxtil", desde os seus produtores até o consumidor final.

Este trabalho foi desenvolvido parcialmente por meio da observação e coleta de dados presenciais.

Como se trata de um assunto relativamente novo - embora existam relatos que comprovem a prática de fabricação deste produto desde a década de 70 -, são poucos os itens específicos encontrados em bibliografias destinadas ao assunto.

Sendo assim, para a pesquisa ser executada, e para que seja possível a descoberta de suas técnicas e maneiras de produção, foram necessários o acompanhamento, a visita e a observação direta tanto dos canais que já comercializam esse tipo de couro como de todo o trabalho executado para a sua produção, desde a obtenção do couro "cru" até a confecção do produto final.

Além disso, para que fosse possível o estudo desse substrato têxtil, foi necessária a análise das matérias primas disponíveis no mercado, através de um olhar mais apurado o surgimento da indústria têxtil desde a descoberta das primeiras fibras até as possibilidades mais recentes.

Por se tratar de uma proposta de reaproveitamento de materiais, a temática sustentabilidade passou por minuciosa análise, desde o surgimento desse conceito, até sua percepção e entendimento atual.

A comparação com outros tipos de couro, assim como seu processo de beneficiamento, serviu como comparação ao processo que é realizado com o couro de peixe e, através de pesquisa de campo e experimentos foi possível descobrir novas técnicas colaborativas com o meio ambiente e fiéis ao processo produtivo, no sentido de não comprometer o resultado estético das peças de roupas que são produzidas com essa matéria prima.

Diversas unidades, como empresas, ONGs, associações, curtumes, confecções, entre 
outros, possibilitaram essa observação direta e o acompanhamento individual do processo.

As etapas de produção, de acordo com o tempo, forma de produção, logística de distribuição e exposição dos produtos, são muito singulares e apresentam diversas variações, de acordo com o perfil do fabricante, mas a intenção do trabalho realizado é unânime.

Foi possível visitar, entrevistar e contatar alguns dos produtores, levando-se em consideração a disponibilidade de agenda de cada um eles.

De acordo com a profundidade do assunto e a oportunidade de explorar novas empresas produtoras de artefatos na área, e por sugestão da professora orientadora do trabalho e Banca de Comissão Julgadora, pretende-se que essa dissertação tenha continuidade de pesquisa no formato de tese de doutorado. 


\section{REFERÊNCIAS BIBLIOGRÁFICAS E WEBGRAFIA}

AAKER, D. A. Como Construir Marcas Líderes. Porto Alegre: Bookman, 2007.

ADEODATO, S. Peles exóticas e ecológicas. Globo Ciência, v. 51, p.56-60, 1995.

ALVES, J. A. L. A. A Cúpula Mundial sobre o Desenvolvimento Social e os paradoxos de Copenhague. Brasília, 1997.

ASHDOWN, S.P. (Org.). Sizing in clothing. EUA: The Textile Institute, 2007.

ASSOCIAÇÃO BRASILEIRA DE QUÍMICOS E TÉCNICOS DA INDÚSTRIA DO COURO. Rio Grande do Sul: Guia Brasileiro do Couro, 2003.

ASSOCIAÇÃO DAS INDÚSTRIAS DE CURTUMES DO RIO GRANDE DO SUL. Rio Grande do Sul: Boletim Estatístico do Couro, 2001.

BALLS, William. The Cotton Planet In Egypt. Inglaterra: Cambridge Library Collection - Naval Chronicle, 2012.

BARNARD, M. Moda e Comunicação. Rio de Janeiro: Rocco, 2003.

BARREIRO, Ana Maira Martínez. La Difusión de la Moda en La Era de la Globalización. Espanha: Revista de Sociologia. Universitat Autónoma de Barcelona. N. 81, 2006.

BARTHES, Roland. O Sistema da Moda. Lisboa: Editora Signos, 1981.

BAUDRILLARD, J. A Sociedade de Consumo. Lisboa: Ed. 70, 1981.

BECK, Ulrich. Sociedade de Risco - Rumo a uma outra modernidade. São Paulo: Tradução de Sebastião Nascimento. Ed. 34, 2010. 368 p, 2010.

BELINK, A. A busca pelo consumo consciente. Santa Catarina: Aron Belink, 2007.

CANCLINI, N. G. Consumidores e Cidadãos - Conflitos Multiculturais da globalização. Rio de Janeiro: Editora UFRJ, 1996.

CARVALHO, I. A Invenção Ecológica. Porto Alegre: Editora da UFRGS, 2001.

CASTRO H. et al. Estudo das condições de saúde, trabalho e vida dos trabalhadores de uma indústria têxtil de amianto no Rio de Janeiro. Rio de Janeiro. Rio de Janeiro: ENSP/Fiocruz, 1999.

CAVALCANTI, C. Meio Ambiente Urbano e Sustentabilidade: Alguns Elementos para 
a Reflexão. São Paulo: Cortez, 1997.

CIDREIRA, P.R. Os sentidos da moda. São Paulo: Annablume, 2007.

CHANDLER, A. Ensaios para a teoria da grande empresa. Thomas A. Mc Graw. São Paulo: Editora FGV, 1998.

CIETTA, E. A Revolução do Fast Fashion: Estratégias e Modelos Organizativos para Competir nas Indústrias Híbridas. São Paulo: Estação das Letras e Cores, 2010.

CLASS, I. C. MAIA, R. A. M. Rio Grande do Sul: Manual Básico de Resíduos Industriais de Curtume, 1994.

COBRA, M. Marketing e Moda. São Paulo: Editora SENAC, 2007.

COLlET, J. J. MAIA, R. A. M. O Mercado Brasileiro de Couro, Tratamento de Efluentes de Curtume - Operação e Controle, Tecnologias limpas na Indústria do Couro. Rio Grande do Sul, 2002.

COMPANHIA DE TECNOLOGIA DE SANEAMENTO AMBIENTAL. Nota Técnica sobre tecnologia e controle de curtumes. São Paulo, 1989.

CRESPO, S. O que o brasileiro pensa do meio ambiente e do desenvolvimento sustentável. Rio de Janeiro: Iser-Ministério do Meio Ambiente, 2002.

D'ACRI, V. O significado do trabalho: o estudo das condições de trabalho e saúde dos trabalhadores de uma indústria têxtil de amianto no Rio de Janeiro. 2002. Tese (Doutorado) Coppe/UFRJ, Rio de Janeiro, 2002.

ECO, Umberto. As formas do conteúdo. São Paulo: Editora Perspectiva, 1974.

ERNER, Guillaume. Vítimas da Moda? Como a criamos, por que a seguimos. São Paulo: Editora SENAC, 2005.

FERREIRA, L C. Sustentabilidade: uma abordagem histórica da sustentabilidade. In: BRASIL. Encontros e Caminhos: Formação de Educadoras(es) Ambientais e Coletivos Educadores. Brasília: Ministério do Meio Ambiente, 2005.

GIANNASI, F. A construção de contrapoderes no Brasil na luta contra o amianto: a 
globalização por baixo. In. GIANNASI, F. Patologia do trabalho. 2. ed. São Paulo: Ed. Atheneu, 2002.

GORE, Al. Uma verdade inconveniente, 2006.

JACOBI, P. Cidade e Meio Ambiente. São Paulo: Anna Blume, 1999.

KATO, C. A. Arquitetura e sustentabilidade: projetar com ciência da energia. Dissertação de mestrado.

KOHLER, C. História do Vestuário. São Paulo: Editora WMF Martins Fontes, 2009.

KOTLER, P. Administração de marketing. São Paulo: Atlas, 1993.

KOTLER P., KELLER K., Administração de Marketing, 12 edição, São Paulo: Pearson Prentine Hall, 2006.

LANG, J. Gestão ambiental: estudo das táticas de legitimação utilizadas nos relatórios da administração das empresas listadas no ISE. Dissertação de mestrado. Universidade Regional de Blumenau, 2009.

LEFF, E. Ecología y Capital. Racionalidad ambiental, democracia participativa y desarrollo sustentable. México: Siglo XXI Editores, 1994.

LIPOVETSKY, G. O império do efêmero: a moda e seu destino nas sociedades modernas. São Paulo: Cia das Letras, 2009.

MARTINS, Suzana Barreto. Ergonomia e Moda: Repensando a segunda pele. In: PIRES, Dorotéia Baduy (org.) Design de Moda: olhares diversos. São Paulo: Estação das Letras e Cores: 2008.

MASLOW. A. H. Maslow no gerenciamento. São Paulo: Qualitymark, 2000.

MELO NETO, Francisco Paulo de : FROES, César. Gestão da responsabilidade social corporativa: o caso brasileiro. 2. ed. Rio de Janeiro: Qualitymark, 2001.

MOURA, L. G. V.. Indicadores para a avaliação da sustentabilidade em sistemas de produção da agricultura familiar: o caso dos fumicultores de Agudo. Dissertação de mestrado. Desenvolvimento Rural. Universidade Federal do Rio Grande do Sul, 2002.

NORO, G.de B.; ABBADE, E.: DENARDIN, E.; SILVEIRA, C. M.; CORADINI , R. A. A Sustentabilidade com base na Gestão de Stakeholders: o Caso Wal Mart. In: Anais VI Simpósio de Excelência em Gestão e Tecnologia - SEGET, Resende, RJ, 2009. 
Biblioteca Digital do BNDES. Produção BNDES. Produção de Artigos. Panorama do Setor de Couro no Brasil. Rio de Janeiro, 2002.

PIRES, Doroteia, Baduy. Design de Moda - Olhares Diversos. São Paulo: Estação das Letras e Cores, 2008.

ROSA, Altair. Rede de governança ambiental na cidade de Curitiba e o papel das tecnologias de informação e comunicação. Dissertação de mestrado. Gestão Urbana. Pontifícia Universidade Católica do Paraná, 2007.

RIES, A. TROU, J. As 22 consagradas leis do marketing. São Paulo: Makron Books, 1993.

SANT’ANNA, Mara Rúbia. Teoria de Moda: sociedade, imagem e consumo. Florianópolis: Estação das Letras, 2007.

SANTAELLA, L. Linguagens líquidas na era da mobilidade. São Paulo: Paulus, 2007.

SCHULTE, N.K. Moda: da estética à ética ambiental biocêntrica. In: Encontro de Sustentabilidade em Projeto do Vale do Itajaí,2., 2008, Balneário Camboriú/SC. Anais... Balneário Camboriú/SC: Universidade do Vale do Itajaí, 2008, p. 79-91.

SCHWEIGERT, L. R.. Plano diretor e sustentabilidade ambiental da cidade. Dissertação de mestrado.

SGARBI, V.S et al. Os Jargões da Sustentabilidade: uma Discussão a partir da Produção Científica Nacional,engema 2008.

SHETH, J. N.; MITTHAL, B. NEWMAN, B. I. Comportamento do cliente: indo além do comportamento do consumidor. São Paulo: Atlas, 2011.

SOLOMON, M. R. O Comportamento do Consumidor: comprando, possuindo e sendo. Porto Alegre: Bookman, 2002.

SORRENTINO, M.E.P. Educação Ambiental, participação e organização de cidadãos. INEP/MEC, ano X, nº49:47-57, jan/mar 1998.

SOUZA, F.A.M. Os axiomas do marketing. São Paulo: Makron, 1998.

TRIGUEIRO, A. Meio Ambiente no Século 21: Especialistas Falam da Questão Ambiental nas suas Áreas de Conhecimento. Rio de Janeiro: Sextante, 2003.

TRISTÃO, M. As Dimensões e os Desafios da Educação Ambiental na Sociedade do Conhecimento. Porto Alegre: Artmed, 2002. 2011.

WEBER, M. A ética protestante e o espírito do capitalismo. São Paulo: Martin Claret,

WOODRUFF, R. B. GARDIAL, S. F. Know Your Customer: New Approaches to 
Understanding Customer Value and Satisfaction. Cambridge, MA: Blackwell Publications.

ABNT NBR 15105, previsto no capitulo III. Disponível em www.airvo.com.br/PDF/INMETRO-LEI-11211.

Acessado em 03/08/2013.

AMOR PEIXE: MODELO DE DESENVOLVIMENTO SUSTENTAVEL. Disponível em: http://d3nehc6yl9qzo4.cloudfront.net/downloads/amor_peixe_portugues_web.pdf.

Acesso em: 16/05/2013.

ARPEIXE: MODA ARTESANAL EXPOSTA NA RIO+20. Disponível em:

http://www.mda.gov.br/sitemda/noticias/moda-artesanal-ser\%C3\%A1-exposta-na-rio20.

Acesso em 20/08/2014.

Arte da Pele. Disponível em: http://www.artedapele.com/artigo04.html. Acesso em: 25/09/2013.

Bicho da Seda. Disponível em:

http://www.den.ufla.br/siteantigo/Professores/Ronald/Disciplinas/Notas\%20Aula/Sericicultur a\%20bichodaseda.pdf. Acesso em 26/05/2015

Biólogo transforma pele de peixe em couro para artesanato no Guarujá. Disponível em: http://g1.globo.com/sp/santos-regiao/noticia/2013/05/biologo-transforma-pele-de-peixeem-couro-para-artesanato-em-guaruja-sp.html. Acesso em: 22/12/2013.

Carnes e Couros tem recorde histórico nas exportações. Disponível em: http://www.suino.com.br/SafrasNoticia.aspx?codigoNot=115242\&title=CARNES:+COURO+

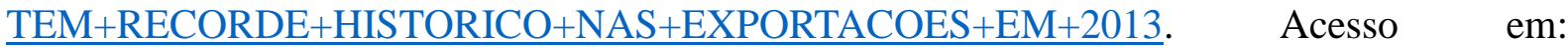
$12 / 10 / 2013$.

Centro do Couro. Disponível em:

http://www.centrodocouro.com.br/website/index.php?option=com_content\&view=category\&1 ayout=blog\&id=75\&Itemid=112. Acesso em: 15 Agosto 2013.

Considerações teóricas sobre o conceito de Sustentabilidade. Disponível em: http://www.aedb.br/seget/arquivos/artigos10/31_cons\%20teor\%20bacha.pdf Acesso em 25/05/2015.

COSTA, L. A. V. da. IGNÁCIO, R. P. Relações de Consumo X Meio Ambiente: Em Busca do Desenvolvimento Sustentável. Disponível em: http://www.ambitojuridico.com.br/site/?n_link=revista_artigos\%20_leitura\&artigo_id=10794\&revista_caderno= $\underline{5}$. Acesso em 25/08/2014. 
Criação de Peixes. Disponível em: http://criacao-de-peixes.info/piscicultura.html Acesso em: 28/05/2014.

Curtumes - Governo do Estado de São Paulo - Secretaria do Meio Ambiente. Disponível em: http://www.crq4.org.br/downloads/curtumes.pdf Acesso em 28/05/2015.

Diferenças entre empresas comerciais e empresas sem fins lucrativos no meio social. Disponível em: http://semanaacademica.org.br/system/files/artigos/artnaianasantos.pdf. Acesso em: 28/05/2015.

Inserção do design de acessórios em couro e escama de peixe no desfile TENEAR/UFRPE da FENEARTE 2013. Disponível em: http://www.eventosufrpe.com.br/2013/cd/resumos/R0304-1.pdf. Acesso em: 28/05/2015.

Instituto Nacional de Pesquisa Amazônica. Disponível em http://institutopiatam.org.br/comunidades_ribeirinhas_modos_de_vida_web.pdf.

Acesso em 12/04/2013.

IPEPS - INCUBADORA PÚBLICA DE ECONOMIA POPULAR SOLIDARIA COOPEG: COOPERATIVA PÉROLAS DO GUARUJA. Disponível em:

http://www.ipepsguaruja.com.br/p/coopeg.html.

Acesso em: 14/07/2014.

Núcleo de pesquisa nupélia. Disponível em: http://peixe.nupelia.uem.br/. Acesso em: 04/01/2014.

O Conceito de Sustentabilidade e Desenvolvimento Sustentável http://www.catalisa.org.br/recursos/textoteca/30 Acesso em 25/05/2015

O Ciclo de Vida do Produto e as Estratégias de Mercado na Gestão de Marcas Sandálias Havaianas - Um Case de Sucesso. Disponível em: http://www.ufjf.br/ep/files/2014/07/2007_1_Fernanda.pdf. Acesso em: 28/05/2015.

Origem da Evolução Têxtil. Disponível em: http://pessoal.utfpr.edu.br/fsouza/arquivos/OrigemeEvolucaoIndustriaTextil.pdf. Acesso em: 10/12/2013.

O Mercado de Curtume do Couro de Peixe. Disponível em: http://agrosebrae.com.br/o-mercado-de-curtume-do-couro-de-peixe/. Acesso em: 28/05/2015.

PALMA, Jorge. Fibras, Fios e Tecidos. Disponível em: http://jorgepalma55.tripod.com/fib.html. Acessado em 12/10/2013.

Pequenos curtumes, grande sacada.

http://planetasustentavel.abril.com.br/blog/biodiversa/pequenos-curtumes-grande-sacada/. 
Acesso em: 19/11/2013.

Pilares da Sustentabilidade. Disponível em:

http://lassu.usp.br/sustentabilidade/pilares-da-sustentabilidade

Acesso em 25/05/2015.

Produção do couro de peixe. Disponível em: http://novakaeru.com.br. Acesso em: 08/01/2014.

Projeto traces - Instituto E. Disponível em: http://www.tracesefabrics.org/. Acesso em: 08/01/2014.

Prevenção e Detecção - Fatores de Risco - Amianto Disponível em: http://www1.inca.gov.br/conteudo_view.asp?ID=15. Acesso em: 27/05/2015

SANTOS, A. M. M. M. CORRÊA, A. R. ALEXIM, F. M. PEIXOTO, G. B. T. Estratégias para o desenvolvimento local e o alcance dos objetivos de desenvolvimento do milênio. Disponível em:

http://www.fiepr.org.br/nospodemosparana/uploadAddress/Reciclando_o_Pescado[39805].pdf

Acesso em: 27/03/2014.

SOUZA, Flávio. Tecnologia Têxtil - Origem e Evolução da Indústria. Disponível em http://FabricioMaest/aula-1-indstria-textil.

Acessado em 25/09/2013.

SUINOCULTURA: carne in natura, embutidos e defumados. Disponível em http://201.2.114.147/bds/bds.nsf/E700C099069CC7A8832574DC004BECAE/\$File/NT00039 0A6.pdf. Acessado em 15/09/2013.

Técnico em agropecuária - Piscicultura. Disponível em: http://200.17.98.44/pronatec/wp-content/uploads/2013/06/Piscicultura.pdf. Acesso em: 28/05/2015. 


\section{ANEXOS}

\section{Utilização de couro de peixe revela mercado promissor}

\section{Por Eduardo Gomes}

Visando evitar o aumento da poluição ambiental dos rios e aumentar o rendimento econômico gerado através do beneficiamento de pele de peixes, o projeto intitulado "Utilização de pele de peixe da água doce para curtimento" poderá reverter quadros alarmantes do que antes era um desperdício de matéria-prima regional.

Coordenado pelo pesquisador da Coordenação de Pesquisas em Tecnologia de Alimentos (CPTA), do Instituto Nacional de Pesquisas da Amazônia (Inpa), Nilson Luiz Carvalho, o projeto, que já existe há 15 anos, tem como um de seus critérios orientar funcionários de frigoríficos e de peixarias para retirada correta das peles, propondo o aproveitamento desta matéria-prima.

De acordo com o pesquisador, devido ao grande consumo de peixes na região norte do país, um número muito alto de pele desses animais é jogado fora a cada dia, sem utilização adequada desses insumos. "Todos os dias é jogada fora no lixo ou até mesmo nos rios cerca de uma tonelada de peles", enfatizou.

Com a implantação de indústrias de beneficiamento de pescado no estado, aumentouse o interesse também no aproveitamento dos resíduos. Além de ser uma atividade economicamente rentável para as comunidades, pelo aproveitamento das peles de peixes, é considerada também um setor promissor no mercado das confecções de roupas, calçados, cintos, acessórios, entre outros produtos.

Até a finalização do material a pele do peixe passa por vários processos, como a classificação, rebaixamento, neutralização, tingimento, engraxe, fixação e acabamento, para só então ser transformada em couro, podendo ser utilizada nas bolsas, roupas e outros produtos feitos com couro de animais.

Para a produção de couro, utilizam-se peles de peixes lisos e de escamas, buscando-se viabilizar economicamente a utilização de espécies diferenciadas, o que diminui o impacto sobre o meio ambiente, já que antes a pele dos peixes não possuía nenhum aproveitamento.

Segundo Carvalho, atualmente o projeto ganhou um apoio da Superintendência da Zona Franca de Manaus (SUFRAMA), através do Projeto "Construção de uma unidade de beneficiamento de pele de peixes amazônicos”, com orçamento de $\mathrm{R} \$ 1.540 .000,00$, que será construída em parceria com a Secretaria de Produção Rural (SEPROR/AM), em um terreno 
cedido no Parque de Exposições Angelino Beviláqua, situado no Km 14 da BR AM 010.

O pesquisador destacou a importância que esses investimentos irão trazer para o projeto. "Com os equipamentos poderemos ter produtos de alta qualidade para competir igualmente com similares, tanto nacional como internacionalmente", ressaltou. Uma das novidades que esta nova fase do projeto vai trazer é que além do desenvolvimento de inovações na pesquisa, serão promovidos cursos de extensão para alunos das escolas técnicas e universitários, possibilitando o aprendizado do processo de produção do couro do peixe para a comercialização.

\section{Couro do pirarucu ganha espaço na alta costura}

O pirarucu, um peixe gigantesco da Amazônia e um dos maiores de água doce do mundo, passou a ter seu couro usado como matéria-prima para a produção de bolsas e sapatos de alta costura. O peixe é famoso por seu tamanho - pode chegar a três metros de comprimento e 250 quilos de peso - e por sua carne de sabor suave e delicioso, com poucas espinhas.

Há seis anos, as escamas do pirarucu também se transformaram em matéria-prima para a criação de acessórios usados por muitas mulheres em capitais da moda como Paris.

A engenheira florestal Rose Dias, do Instituto Nacional de Pesquisas da Amazônia (INPA) e uma das proprietárias da empresa Green Obsession, explicou como nasceu este projeto, pelas mãos do organismo estatal, para criar uma inovadora marca de moda que "dá valor" à Amazônia.

- "Mais um" não é interessante para nós. Temos o diferencial de sermos ecologicamente corretos e utilizarmos produtos de manejo florestal, excedentes da floresta e sem produzir devastação - afirma Rose.

O pirarucu é um peixe em extinção, cuja pesca está proibida no Brasil. Ele só pode ser obtido em unidades de conservação e viveiros, sempre com supervisão dos organismos de fiscalização do meio ambiente.

Rose afirma que sua companhia tenta dar prioridade às comunidades ribeirinhas, muitas das quais vivem exclusivamente de sua pesca, embora também adquiram o couro de empresas do ramo alimentício, que contam com pisciculturas próprias.

Tradicionalmente, o pirarucu costumava ser assado na brasa e "não sobrava nada" do 
couro. Porém, depois que passou a ser comercializado por grandes empresas, toda a pele começou a ser descartada, segundo a engenheira. Então, o INPA pensou que este material, que representa $10 \%$ do peso do animal, poderia ganhar alguma utilidade, gerando mais renda para a cadeia produtiva.

O couro deste peixe apresenta vantagens em relação ao bovino: sustenta mais tensão, já que suas fibras são entrelaçadas, enquanto as da pele dos bovinos estão dispostas em paralelo, segundo os estudos do INPA (INPA, 2014).

A empresa também utiliza outros peixes da região, como o tucunaré, um animal de tamanho intermediário, que mede entre 30 centímetros e um metro de comprimento.

No total, sete pessoas trabalham na empresa regularmente. Porém, em função da demanda, mais empregados são contratados. A mão de obra é recrutada em comunidades pobres, onde a empresa oferece cursos de capacitação, necessários porque a confecção das peças é mais difícil devido às características dos animais.

- É preciso saber trabalhar o peixe, já que o tamanho oferece mais dificuldades do que o couro bovino e exige costurar muitas peças à mão - explica Rose.

A Green Obsession já produz em média 200 peças ao ano, entre sapatos e bolsas. Os produtos da empresa já encontraram compradores em cidades como São Paulo e Belo Horizonte.

Além disso, a companhia já exporta seus produtos para França, Itália, Estados Unidos e Canadá, graças a contatos realizados na Feira Internacional da Amazônia, realizada anualmente em Manaus, e também por pedidos realizados por profissionais da moda que faziam turismo na região.

Rose revelou que chegou a receber uma proposta de uma renomada empresa francesa para que fabricasse peças com sua marca, mas a rejeitou argumentando que isso diminuiria a relevância do produto da região amazônica.

\section{Couro de peixe: essa moda pega?}

\section{Por Vila Fashion}

O couro é um material que nunca sai de moda. Coleções vão e vêm e ele sempre aparece em algum lugar, em especial nos acessórios.

O couro costuma ser um artigo bem popular no Brasil, e normalmente inspira elegância. 
Atualmente, uma ideia inusitada promete incrementar as opções em couro e deixá-las ainda mais "brasileiras": o uso da pele de peixes para a confecção de diversas peças. A iniciativa conta com o incentivo da Secretaria de Desenvolvimento Sustentável do Amazonas, por meio do projeto AMA (Ame o Amazonas), e de uma conhecida marca inserida no mercado têxtil e de confecção, a Iódice.

Apesar de ser uma renovação nos setor de peles, o couro desses peixes já vem sendo pesquisados há algum tempo. De acordo com Nilson Carvalho, coordenador do Projeto de Beneficiamento de Couro de Peixe do INPA (Instituto Nacional de Pesquisas da Amazônia), a primeira tentativa de uso desse material aconteceu em 1967, em Manaus. Há pouco mais de 10 anos que o órgão obteve resultados positivos em pesquisas feitas com pele de várias espécies com ou sem escamas, como tambaqui, tucunaré, pirarucu, surubim, pirarara e filhote de piraíba. "Firmamos algumas parcerias com a iniciativa privada, porém as tentativas não vingaram no sentido de colocar o produto no mercado", diz Nilson.

No entanto, ele acredita que, dessa vez, o projeto renda bons resultados. Até porque, hoje, existe o interesse de empresas privadas no uso do couro de peixes amazônicos. A Iódice, por exemplo, resolveu investir nisso, sendo parceira do Estado. "A parceria funciona a partir de indicações junto às unidades de conservação, que são 52. Adotei uma unidade de conservação da Reserva Extrativista do Rio Gregório. E a cada peça (feita de couro de peixe) vendida nas lojas não só de acessórios, revertemos R\$ 1 para essa unidade”, explica Valdemar Iódice, responsável pela marca. Ele descobriu o couro de peixe depois de uma viagem de estudos ao Amazonas, para criação de uma coleção.

A empresa gaúcha Péltica (www.peltica.com.br) vende esse tipo de pele para fábricas de calçados e bolsas, mas também para o setor moveleiro e de interiores. E o uso se dá devido a algumas vantagens, apontadas por Alexandre Frasson, sócio na empresa: matéria-prima abundante no Brasil, beleza, exotismo, exuberância, diversidade, resistência do material e sustentabilidade.

A justificativa da Péltica faz sentido se observarmos dados da Agência de Desenvolvimento Sustentável do Estado do Amazonas (ADS). Cerca de 10 milhões de peixes poderiam ser fornecidos para curtumes e aproximadamente três toneladas de peles poderiam ser aproveitadas diariamente no Estado. "A utilização desta matéria-prima em escala industrial evitaria a emissão de várias toneladas diárias de resíduos sólidos, minimizando o impacto sobre a natureza e, ao mesmo tempo, gerando riquezas únicas e renda para toda a cadeia produtiva do pescado", observa Alexandre.

Segundo o coordenador do Projeto de Beneficiamento de Couro de Peixe do INPA, o 
governo do Estado pretende investir uma alta quantia para construir um curtume com capacidade suficiente para um beneficiamento satisfatório da pele de peixes da região. O novo curtume faz parte de um projeto que tem por objetivo a utilização continuada desse material no Brasil e no mundo, por meio de pesquisas, extensão e treinamento de produtores locais e quem mais se interessar em trabalhar com essa matéria-prima.

Olhando para qualquer peça feita do exótico material, observamos que ela é única, pois cada peixe tem um desenho diferente em sua pele, assim como as impressões digitais encontradas nos seres humanos.

Portanto, os itens são exclusivos e a diversidade é incrível. Parece que essa moda pega, sim. Na Europa, peças usando esse tipo de matéria-prima já são vendidas por até R\$ 6 mil. 